\title{
SIX BOOKS
}

\section{OF THE}

\section{COMMONWEALTH}

\author{
by JEAN BODIN
}

Abridged and translated by M. J. TOOLEY

BASIL BLACKWELL OXFORD

PRINTED IN GREAT BRITAIN IN THE CITY OF OXFORD AT THE ALDEN PRESS BOUND BY

THE KEMP HALL BINDERY, OXFORD

[taken from the Liberty Library of Constitutional Classics]

$<$ http://www.constitution.org/liberlib.htm> 


\section{CONTENTS}

INTRODUCTION

I. Biographical Sketch.

II. The Argument of the Six books of the Commonwealth.

TRANSLATOR'S NOTE.

BIBLIOGRAPHICAL NOTE.

\section{THE SIX BOOKS OF THE COMMONWEALTH.}

BOOK I [The chapter numbers in brackets are those of the original French.]

The final end of the well-ordered commonwealth [Chapter I] 1

Concerning the family [Chapters II-V] 6

Concerning the citizen [Chapters VI and VII] 18

Concerning sovereignty [Chapter VIII] 25

Concerning feudatory and tributary princes [Chapter IX] 36

The true attributes of sovereignty [Chapter X] 40

\section{BOOK II}

Of the different kinds of commonwealth [Chapter I] 51

Concerning despotic monarchy [Chapter II] 56

Concerning royal monarchy [Chapter III] 59

Concerning tyrannical monarchy [Chapters IV and V] 61

Concerning the aristocratic state [Chapter VI] 69

Concerning popular states [Chapter VII] 72

\section{BOOK III}

The council [Chapter I] 77

Officers of state and holders of commissions [Chapters II and III] 80 
The magistrate [Chapters IV and V] 84

Concerning corporate associations, guilds, estates, and communities [Chapter VII] 96

\section{BOOK IV}

The rise and fall of commonwealths [Chapter I] 109

That changes of government and changes in law should not be sudden [Chapter III] 123

Whether the tenure of office in the commonwealth should be permanent [Chapter IV] 128

Whether the prince should render justice to his subjects in person [Chapter VI] 133

How seditions may be avoided [Chapter VII] 138

\section{BOOK V}

The order to be observed in adapting the form of the commonwealth to divers conditions of men, and the means of determining their dispositions [Chapter I]

How to prevent those disorders which spring from excessive wealth and excessive poverty [Chapter II]

Concerning rewards and punishments [Chapter IV]

Whether it is expedient to arm subjects, fortify and organize for war [Chapter V]

The keeping of treaties and alliances between princes [Chapter VI]

\section{BOOK VI}

The census and the censorship [Chapter I]

The revenues [Chapter II]

A comparison of the three legitimate types of commonwealth, popular, aristocratic, and monarchical, concluding in favour of monarchy [Chapter IV]

That in a royal monarchy succession should not be by election nor in the female line, but by hereditary succession in the male line [Chapter V]

Concerning distributive, commutative, and harmonic justice, and their relation to the aristocratic, popular, and monarchical states [Chapter VI] 


\section{INTRODUCTION}

\section{BIOGRAPHICAL SKETCH}

JEAN BODIN, like Machiavelli, was one of those writers whose political thinking developed under pressure of personal experience. The Six books of the Commonwealth was published early in 1576, and more than any of his other works, reflects all the facets of his very varied experience. It is the work of a humanist who had had a conservative education; of a jurist who was as familiar with the work of Du Moulins on the customary law as of the medieval civilians; and of a patriot who had turned his attention to politics in the conditions produced by the Wars of Religion. The circumstances under which the first years of his life were passed explain how he came to be all these things.

He was born in Angers in 1529 or 1530 of a prosperous bourgeois family. His first patron was its bishop, Gabriel Bouvery, a man of influential connections -- he was a nephew of Francis I's Chancellor Poyet -- and a scholar versed in Latin, Greek and Hebrew. Under his influence, at the early age of 15 or 16 years, Bodin was professed in the Carmelite house of Nôtre-Dame at Angers, and then sent with three other young monks to be educated at the house of their Order in Paris.

In Paris he came in contact with both the old and the new learning. His style of exposition makes it clear that he was trained in the old methods of formal argument. It is also clear that he was grounded in the traditional aristotelianism of the schools, without however succumbing entirely to its influence. He was familiar with Aristotle, but nearly always treats him as the antagonist to be refuted rather than the master to be followed. What, understandably enough, he seems to have found more attractive was the new learning centred in the Collège des Quatre Langues, later to become the Collège de France, where linguistic studies replaced theological, and Plato superseded Aristotle as the master philosopher. Its courses were open to all who cared to attend, and there Bodin probably acquired his extensive knowledge of Greek and Hebrew literature, and his platonism. As a legacy of his Paris education his style was permanently modelled on the disputation, but he was a man of the renaissance in preferring Plato to Aristotle, and in being at any rate as much interested in the humane studies of languages and history as in philosophy and theology.

His first sojourn in Paris ended when he was 18 or 19 years old with his leaving the convent, after being dispensed from his vows, and abandoning the study of philosophy and the humanities for that of law. The circumstances leading up to this great change of direction are obscure. But in 1547 the prior of the Carmelites of Tours and two brothers, one of whom was named 
Jean Bodin, were cited before the Parlement of Paris for having too freely debated matters of faith. In the event the prior and one of the brothers, but not Jean Bodin, were burned. It is not certain whether this was the author of the Six books of the Commonwealth, for the name Jean Bodin was fairly common in the sixteenth century, nor why he escaped, whoever he was. Did he recant? Or was influence used to save him, perhaps that of Gabriel Bouvery? Our Jean Bodin's written works are evidence that he was the sort of man who might easily have got into such dangers in his youth. His last book, the Heptaplomeres, a dialogue between people of different religious faiths, shows him to have been deeply interested in religion, to have been profoundly curious about all the various systems of belief professed in his day, and to have reached so detached a judgement of them that what his own convictions were is a matter of some controversy. He always expressed great repugnance for any policy of forcing men's consciences, and declared in the Heptaplomeres that under such a threat a man was justified in concealing his convictions. He never risked publishing this work. If the Carmelite of 1547 was our Jean Bodin, the reason for his leaving the dangerous environment of the convent becomes clear; and his attitude to religious persecution, and his tendency to conform his own religious profession to time and place, is explained.

The same sort of ambiguity hangs over what may have been another incident in his religious experience. In 1552 a Jean Bodin was in Geneva and left about a year later. If this man also was our Jean Bodin it is evidence of his desire to acquaint himself thoroughly with what Calvinism stood for, but one cannot be certain of anything else than that he must have conformed openly to Calvinist practises. The treatment of Calvinism in the Heptaplomeres does not suggest that he became, much less remained, a convinced Calvinist. The burning of Servetus for heresy in 1553 might well have determined his leaving the city.

Before this happened, about 1550 , he had embarked on the study of the civil law, and but for the possible break in 1552, was for ten years in Toulouse, both as student and teacher. That is to say his life in Toulouse was the counterpart of his life in Paris. His environment was academic, and his activities those of a scholar, though Roman law had replaced the classics as the subject of his studies.

His entry into the world of affairs came in 1561 when he abandoned the teaching of the law for its practice, and went to Paris to be called to the bar. He had, of course, to take the oath declaring his catholic orthodoxy required of every avocat du roi on entering into his office. The removal involved more than a change of occupation, important as that was to his development as a writer. The climate of legal opinion was very different in Paris from what it had been in Toulouse. In south France the new learning 
had invaded the law schools. A new jurisprudence, especially associated with Bourges, and the name of Jacques Cujas, developed out of the humanist passion for recovering and reconstituting the classical past. The great medieval civilians, a Bartolus or a Baldus, consciously adapted Roman law to the legal requirements of their own age, just as the medieval grammarian consciously developed Latin to be a vehicle for expressing his own processes of thought. To Cujas this was a work of barbarization, and he aimed at restoring the original text of the corpus iuris civilis. The results of his endeavours was one of the monuments of renaissance scholarship, and put him in the front rank of sixteenth-century jurists.

Paris lawyers were at once more conservative and more practical, perhaps because the customary law of the north, though deeply penetrated by the principles of Roman law, was not a derivation from it, as was the case in the south, but fundamentally an indigenous growth. The Paris lawyer, concerned with the problems of actual legal practice, necessarily therefore perpetuated the Bartolist tradition in his treatment of Roman law. What interested him more, because of its practical import, were projects for the codification and unification of the still very localized law of north France. Such a project, first mooted under Charles VII, was taken very seriously by Louis XII who ordered an extensive survey of the kingdom to collect the necessary material, and while Bodin was in Paris was being actively prosecuted by the Chancellor, Michel de L'Hôpital, despite the distraction of the political situation. This comprehensive attitude to law Bodin found far more sympathetic than the purism and exclusiveness of the law universities. In the Six books of the Commonwealth Bartolus and Baldus are the authorities on the civil law that he constantly appeals to. Along with them he cites Charles Du Moulins on the customary law with equal respect. Cujas is only quoted in order to be refuted.

Projects of codification were inspired in the first instance by considerations of administrative convenience. But they appealed also to scholars, among them Bodin, who represented another aspect of the French renaissance than the classicism of Cujas and his school, and that was its universalism. This was quite different from the universalism of the schoolmen, which was a matter of abstractions, and centred on the problem of form. What French humanists of the first half of the sixteenth century were interested in was the integration of concrete facts into comprehensive and comprehensible systems. Religion being the urgent topic of the day, it was the search for the universal and comprehensive religion which most engaged their attention, and encouraged the hope that some sort of agreed formula could be reached which would unite Catholic and Huguenot.

Bodin, the humanist and the civilian turned lawyer, embarked on an enquiry into universal law. But he did not approach it through the study of texts 
and judgements, despite his experience both as teacher and practitioner, for universal law, he thought, was best ascertained through a study of history. He was not original in this respect, such ideas were in the air. François Hotman made the same association in his Antitribonien published in 1567. But the previous year Bodin had already produced his far more thorough and systematic study, The Method for the Easy Comprehension of History.[1] He announced his plan in the Dedication ' [The civilians] have described the laws of no people except the Romans. They should have read Plato, who thought that one way to establish law and government in a state was for wise men to collect and compare all laws of all states, and from them extract and combine the best models.' The Method therefore -- though Bodin reviewed all the available material in the form of histories and travel-books, ancient and modem -- was not just a scholarly examination of sources. His emphasis was on the comprehension of history. What he wanted to establish was what experience had shown to be the best and most enduring forms of law. 'In history the best part of universal law lies hidden; and what is of great importance for the appraisal of laws -- the customs of peoples, and the beginnings, growth, conditions, changes and decline of all states -- are obtained from it. The chief subject-matter of this Method consists of these facts, since nothing is more rewarding in the study of history than what is learnt about the government of states.'

Bodin in fact, by the time he came to write the Method was already more interested in forms of government than forms of law. In Paris apparently he found himself too near to the centre of things to escape being drawn into the overmastering preoccupations of the times, religion on his first visit, and politics on his second. The development of his career emphasized this bias by bringing him new contacts. In 1571 he entered the household of the King's brother, François duc d'Alençon, as master of requests and councillor. This brought him into the world of high politics just at a time when politics were already engaging his attention. The Six books of the Commonwealth is evidence of the extent to which he made use of the opportunities of his position. He inspected diplomatic correspondence, and conversed with foreign ambassadors or Frenchmen returned from abroad. He also came with Alençon to England, and saw something of the court of Elizabeth and the University of Cambridge. In 1583 he accompanied him on his journey to the Netherlands.

In the household of Alençon he was in a world intellectually congenial to him. The Duke was the official leader of the party of the politiques, whose distinction it was, in an age of rising fanaticism, to hold that the state is primarily concerned with the maintenance of order and not with the establishment of true religion. The party therefore stood for the absolute authority of the monarchy to determine the measures necessary to that end, and its unqualified right to demand obedience, as against the doctrine of 
the right of resistance in the name of religion. A public and official statement of these principles had been made by the Chancellor, Michel de l'Hôpital, in his speech to the Estates of Orleans in 1560, just about the time Bodin came to Paris. It fell on ears mostly deaf. In 1562 the long series of the Wars of Religion started, and for the space of thirty years France enjoyed neither settled peace nor order. At this stage of his career, in these circumstances, and in this environment, Bodin composed the Six books of the Commonwealth, published in 1576.

Civil war inspired him with a horror of rebellion and the anarchy that comes in its train, and convinced him that the politiques were right, and that the only remedy was the recognition of the absolute authority of the state 'to which, after immortal God, we owe all things'. Roman law suggested to him the essential concept of such a power. But the comparative historical studies already undertaken in the Method enabled him to free the concept of sovereignty from its particular Roman associations, and to consider it in general as the mark of all types of states at all times. His conviction that it is the condition of human well-being that this power must in all circumstances be preserved led him into the attempt to construct a universal science of politics.

Almost immediately after the publication of the book his career took a downward turn. This had nothing to do with the work itself, but was a consequence of his disinterested conduct as deputy for Vermandois in the Estates of Blois. The occasion proved to be one of the first importance. Since the Estates of Tours in 1484, assembled by the Regency on the death of Louis XI, there had been none in France till Francis I summoned them to meet at Orleans in December 1560. His death a few days before they assembled robbed the meeting of any direction, and they were dissolved in January. The Estates-General met again that year at Pontoise, but was again overshadowed, this time by the Colloquy of Passy, which was looked to more hopefully for a solution of the growing religious troubles of the kingdom. It failed however and civil war started. Therefore the expedient of a meeting of the Estates was again tried. This time they were summoned to meet at Blois in December 1576.

The opportunity was the Paix de Monsieur which had brought a lull in hostilities. The politiques hoped to convert it into a lasting peace by negotiating a settlement. But the Catholic League had just been founded by the intransigent conservatives, and it dominated the two privileged orders of the nobles and the clergy. In these circumstances religious peace was unattainable. Much important business was nevertheless transacted. The Estates discussed a considerable programme of administrative reform, and financial expedients to relieve the chronic inadequacy of the revenues. The results of these deliberations were embodied in the bills of recommendation 
presented by the three estates, and on these the great Ordinance of Blois of 1579 was based, for the Estates could only petition for legislation. The framing and publication of edicts belonged to the Crown.

Judging by what he says in the Six books of the Commonwealth these Estates, the most important of any that met in the sixteenth century, were a model of what Estates should be to Bodin's mind. Yet his personal share in them was disastrous to himself. It was his first and only appearance in public life, and also the only occasion on which he made an open stand for principles in circumstances damaging to himself. He perhaps found the courage, or the conviction, necessary to do this because it was the future of France, and not simply his own safety, which was at stake. His sense of the importance of the occasion led him to publish an account of what had happened in a pamphlet entitled Recueil de tout ce qu'il s'est négocié en la compagnie du Tiers Etat de France ... en la VIIIe de Blois. In an assembly dominated by the Catholic League, of which the King himself, Henry III, was aspiring to become head, he opposed the reopening of the war against the Huguenots, and urged that a solution of the religious problem could only be achieved by negotiation. He upheld the right of the third estate to dissent from the recommendations of the two privileged orders, despite their opposition. He opposed as damaging to the monarchy the alienation of royal domain as a means of raising money for the prosecution of the war.

His success in the last two instances cost him the favour of the King. When therefore the Duc d'Alençon died in 1583, he retired from Paris and took up the office of procurateur au présidial de Lâon which he inherited from his brother-in-law in 1578. Provincial seclusion did not, however, mean peace and security. In 1588, on the assassination of its leader, the Duc de Guise, the League started a reign of terror in Lâon as in so many other places in France, and Bodin thought it prudent to join an association which stood for everything in both politics and religion which he utterly condemned. The advent of Henry IV in 1594, and the long-deferred triumph of the policy of the politiques, could not have been anything but profoundly welcome to him. But if he had entertained any hopes of restored favour, his joining the League cost him any advancement. He was still in Lâon when he died towards the end of 1596 .

Judging by his writings at this time, however, his withdrawal from politics went deeper than a mere change of scene and occupation. There was also an intellectual withdrawal. He abandoned his preoccupation with men and affairs in favour of the contemplation of the order of nature, and an enquiry into the truths of religion. He was still the same Bodin however in search of a universal system. In the Novum Theatrum Naturae of 1594 he set out to describe the universal system of nature, and the unpublished Heptaplomeres[2] was a search for the principles of universal religion. It 
is also significant of this shift of interest that of his minor works, the essay on currency belongs to the second Paris period, while in Lâon he composed the Demonomania, a study of the influence of good and evil spirits in the world. It could hardly have been the result of any deliberate plan, but in fact the order of Bodin's intellectual development, as reflected in his writings, follows the order of man's ascent from the contemplation of his fellows to the contemplation of nature and of God, described in the Six books of the Commonwealth as the fulfilment of the end and purpose of life.

Despite this withdrawal he was already a famous man at the time of his death. Ten editions of the Six books of the Commonwealth appeared in the French version during his lifetime. In 1586 he published a slightly expanded Latin version, and two more editions of this appeared before he died. Other translators rendered the book into Italian, Spanish, German and English. But his fame, though great, was comparatively short-lived. New editions of his book continued to appear at intervals till the middle of the seventeenth century after which the stream dried up. This was because, though the book did much to bring about a revolution in political thinking, once that was accomplished it had not the literary qualities to recommend it to the general reader. It remains all the same an important book, both in its own right, and as a landmark in the history of political thought.

\section{THE ARGUMENT OF THE SIX BOOKS OF THE COMMONWEALTH}

THE true turning points in the history of political thinking are marked not so much by new things that are said, as by new questions that are asked. With the possible exception of the authors of the Defensor Pacis, no one in the middle ages asked 'What is a state and how is it constructed?', but only 'Who are the rulers and what are their powers?' Even Machiavelli, individual as he was in treating the state as existing in its own right without reference to any higher purpose or order, never asked this question. But Bodin did, and so got away from the endless debate on the relations of temporal and spiritual powers, and found the new approach required of the new situation which had arisen in the sixteenth century.

The break-up of the medieval Church destroyed the framework of the older forms of political thinking. So long as there was a universally recognized Church, having authority, it was possible to conceive of a realizable order in Christendom in terms of obligation to the Church. To require princes to act as the sword of the Church, or subjects to renounce their allegiance to an excommunicate ruler, might be unpalatable, but were not impracticable commands. But when princes and subjects alike had first to make a decision as to what was the Church they recognized, such commandments could only, and did, lead to confusion. Some other focus of political obligation had to be found before order could ensue. 
His French environment, and his sympathy with the party of the politiques probably helped Bodin to recognize where the new centre of gravity lay. He no longer talks about the temporal and spiritual powers, the Church and the secular ruler, but about the commonwealth, la république. Moreover he described it with what was recognized to be such insight into its essential character, that all but the simplest political thinkers that came after him, whether they agreed with him or not, thought and wrote not about the powers that be, but the political community as such, and in terms used by him.

For a modem reader the newness of his outlook is somewhat disguised by its formal academic presentation. By comparison with Machiavelli, for instance, he seems to belong to an earlier tradition of political writing. It is true that he did so. His university education along traditional lines turned him out a formal and systematic thinker not only by habit but also by training. Without always keeping to the strict form of the disputation, he nevertheless followed the method in principle in establishing his conclusions. Whether he was discussing slavery [I, v], the exercise of the royal prerogative of justice [IV, vi], or the best form of the commonwealth [VI, iv], he first put the subject to be debated in the form of a question, then assembled all the arguments that could be urged on one side and the other, proceeded point by point to rebut the view which he rejected, and so established a reasoned conclusion. The Six books of the Commonwealth has in consequence about as much pretension to literary grace and charm as a scholastic treatise, and the full text makes very laborious reading. But it also has the merits of its defects. The exposition is complete and coherent. The other, and even more important lesson that Bodin learned in the schools was to achieve clarity and unambiguity by careful definition of all the important terms used. It was these definitions that on occasions he quite rightly claimed were new, and that a generation that was fast casting behind it the rigid formalism of the schools found most arresting and most illuminating.

The opening sentences of the Six books of the Commonwealth betray the original plan of the whole work. Bodin starts by defining the commonwealth as 'the rightly ordered government of a number of families and of those things which are their common concern, by a sovereign power'. He then goes on 'we start in this way with a definition because the final end of any subject must be understood before the means of attaining it can profitably be considered, and the definition indicates what that end is'. In other words he is concerned to establish first what a state is and the ends for which it exists, and then to discuss the practical policies necessary for their accomplishment. His book is therefore a work of the same mixed character as Aristotle's Politics. That is to say it is concerned at once with a philosophy of the state, and with the science of politics. In fact, although he seldom mentions Aristotle except to disagree with him, the 
Politics obviously provided the general model for the Six books of the Commonwealth. The structure is the same. The first two books of the latter work reproduce the order of the argument in books I and III of the former, being concerned with establishing the nature of the state as such, its end, its foundation in the family, citizenship, and the possible forms the state can assume, and in the same order. Again, Bodin shared Aristotle's lively interest in the causes of the preservation and destruction of states, and therefore the theme of books IV and V in the Six books of the Commonwealth bear a general resemblance to the central books of the Politics. But in this part of the work, where he is concerned with the practice, and not with the theory of politics, Bodin moves away from Aristotle. For one thing the great difference in political conditions in ancient Greece and in his own times meant that there could be little correspondence in the particulars of this discussion. The problems were not the same. Moreover there is an urgency in Bodin's writing that one does not sense in the Politics. He wanted to remedy, not just to analyse, the evils of the times. As he says in the Dedication, when the ship of state is in danger of foundering, it behoves the very passengers to give what assistance they can, and it is in the hope of restoring the ancient splendour of the French monarchy that he has undertaken to write on the commonwealth. The theme of what is to be done and what avoided becomes more and more insistent as the argument proceeds, and altogether dominates the later books.

But as has been said, though France might be his immediate concern, he wanted to enlarge his enquiry so as to arrive at a universal science of politics. His procedure was the same as that already used in the Method, induction from the known relevant facts. He surveyed all the evidence about the way the state works, much as Aristotle conducted a preliminary enquiry into the constitutions of Greek city states, only he did what Aristotle did not do, included all this material in the main work. For Bodin the relevant facts were in the first instance all the information he could collect about the contemporary world from the dominions of the Grand Turk to the New World, and from Sweden to Ethiopia. His sources were those already used for the enquiry into universal law, the accounts of travellers and contemporary historians such as Leo the African and Francesco Alvarez, Paolo Giovio and Las Casas, Machiavelli, Guicciardini and the Venetian constitutional historians, Sleidan, Sigismond d'Herberstein and many others. As has been shown, this information he checked, supplemented and brought up to date by inspecting diplomatic correspondence, and talking with diplomats whenever he could.

In the second place the relevant evidence included, he considered, the facts of past history. This meant for him, as for all men of the renaissance, primarily the ancient world as portrayed by the Greek and Roman historians, and he shared the characteristic humanist admiration for its achievements. 
But he also had a good deal to say about medieval France, and had troubled to consult the archives at Rheims, Beauvais and elsewhere. He knew something about England, and how the Empire and the Papacy had developed during the middle ages. As he had already explained in the Method, the study of history is not only the means of discovering the principles of universal law, but also of political wisdom. 'For acquiring prudence nothing is more important or more essential than history, because episodes in human life recur as in a circle, repeating themselves.' It is clear that he regarded history as the record of a series of recurrences rather than of a process of change. As will appear later, his cosmological system implied that the order of events is cyclic and not evolutionary. History therefore is a storehouse of immediately relevant examples, mostly of the character of cautionary tales. He could in consequence assume that the proper collection and collation of these examples would enable one not only to interpret contemporary politics, but also to formulate rules for the guidance of statesmen which should have a timeless validity, 'reliable maxims for what we should seek and what avoid'.

Such use of such material for the building up of the science of politics was not original. The resemblance to Machiavelli is too close to be fortuitous. Machiavelli's collected works were published in 1550, and Bodin refers to the Prince, the Discourses on Livy, and the History of Florence, besides basing a chapter $[\mathrm{V}, \mathrm{v}]$ on the Art of War. In the introduction to the Discourses he could find the statement that history is the proper study of the statesman because, human nature being constant, men always behave in the same way, and therefore the same sequence of cause and effect is always repeating itself. One learns by the experience of others. In the Prince and the Discourses he could see Machiavelli applying this principle by regularly juxtaposing examples of what he was discussing taken first from ancient and then from contemporary history, deducing general conclusions, and so proceeding to frame general maxims. Bodin took over the method but vastly extended the scope. He thought Machiavelli's survey too restricted to allow of conclusions universally valid, and complained that he was very ignorant of many things because he had not read a sufficiency of good books, nor acquainted himself with any peoples but the Italians. Hence what appears to be Bodin's prolixity. It was a consequence of the extent of the field he surveyed, and, it must be admitted, his inability to condense or select.

The science of politics, like any other science, is shaped by the questions asked, and for which an answer is sought. Here again Machiavelli suggested some, though not always all the most important, questions asked. Ought princes to keep the terms of the treaties they made? Should they aim at being rather loved or feared by their subjects' Is it expedient to arm one's subjects and train them for war? But here the resemblance ends. It is an indication of the fundamental difference in values between the two men that 
the answers are always different where morals are concerned. If Machiavelli holds that a prince is only bound to keep a treaty when it furthers his interests, Bodin says he must do so if the interests of the other party to the treaty are at stake [I, viii]. If Machiavelli argues that a prince should rely on fear to keep his subjects obedient and in awe, Bodin thinks that he should win their affection because friendship and not interest is the bond of society [IV, vi].

It is clear from these instances that for Bodin the science of politics was not just a study of the technique of successful government as it was for Machiavelli. He borrowed the method of investigation, but he strongly reprehended the lack of regard for moral principles, and in the Dedication classed Machiavelli with the apologists of the right of rebellion, as the writers whose doctrines had caused the ruin of commonwealths in his own day. He had as clear a vision as the Italian of what states are like, and of how men conduct themselves politically. But unlike the Italian he always measured them by an absolute standard of right to which they ought to conform. Therefore for him the examination of things as they are did not cover the whole enquiry necessary. An historical survey can be made to yield conclusions about what are politically expedient ways and means, but he did not think it was capable of determining the ends to which those ways and means should be directed. He rejected the notion that one can arrive at a true conception of the proper order in human affairs by considering things merely as they are. This comes out in his discussion of slavery [I, v]. He will not allow that it can be defended as a natural institution simply because it has always existed among men. It is the work of sin, not of nature, and condemned as such by Jew, Christian, and Mohammedan alike.

This is indicative of his whole approach to politics. His values are as traditional as was his cosmology. He thought of the natural order as contained within an eternal order comprehending the universe and all particulars within it, in a single system of relationships. To that order all actions and all institutions must be referred as their end. It is spontaneously realized in all created things save man. The proper motions of the heavenly bodies can be determined by observation because in them there is no imperfection. But when one comes to consider men, the divine and natural intention has been disturbed by the Fall. The proper order of human society cannot therefore be determined by observation simply, because men are imperfect. To know that order we must consult natural reason, and with even more certainty, the law of God revealed in the scriptures. For Bodin therefore, as he himself observed at the beginning, the science of politics must be founded in a philosophy of the state indicating ends.

Moreover a moral imperative is implied since men, knowing by revelation and the light of natural reason what the divine intention is, are bound in 
conscience to endeavour to realize it.

In fact Bodin's political thought was rooted in a body of dogma, the law of God. It should perhaps be observed in passing that he appears to mean the Old Testament Scriptures alone. There is no single citation from the New Testament throughout the work, and a reference to the trial of Christ is only there to illustrate the powers of Roman provincial governors. Bodin had read Calvin, and forcibly approved his condemnation of rebellion, yet he never mentions Romans xiii on which it was based [II, v].

From these premises it is not surprising to find that Bodin was at one with Calvin and the earlier reformers in seeing the state as originating in the Fall. The disorder and violence of the times he lived in converted what had been a traditional doctrine into a living belief. The state is necessary because men are wicked. But whereas Calvin adhered to the old view that the sin was the sin of rebellion against "the commands of God, for Bodin it was the sin of injustice against one's fellow men. He reverts several times to the theme that the state originated in violence [I, vi and IV, i]. Sometimes he represents it as the consequence of a passion for dominion, of which Nimrod was the first exemplar. At others he ascribes it to an instinct of mutual association as a means of protection against such acts of violence [III, vii]. But in either case, it is the same evils which threaten men, the destruction of their liberty and the seizure of their possessions.

This shift of emphasis to be observed when one passes from Calvin to Bodin is significant of a newly developing doctrine of rights inherent in the individual, and prior to the state. In the second half of the sixteenth century the old conception of the primitive state of innocence was undergoing important modification. The liberty that men enjoyed in that primitive natural society was assumed not to have been lost -- as Calvin thought it had been lost -- but to be inalienable, and its preservation the foundation of all legitimate political authority. Such views were being expressed by François Hotman in his Franco-Gallia of 1573, and a short while after the publication of the Six books of the Commonwealth in the Vindiciae contra tyrannos of 1579. Bodin never used such phrases as 'natural rights', or 'inherent rights'. But he assumed all through two rights in the individual sanctioned by divine and natural law, liberty and property.

For once his treatment of the subject of liberty was fragmentary, perhaps because his preoccupation with order led him to approach the state throughout from the point of view of the authority of the ruler, rather than that of the rights of the subject. But his main conception is clear. He defined natural liberty as perfect freedom to live as one pleases, subject only to the rule of reason [I, iii]. This is qualified when a man becomes a citizen by the obligation to obey the ruler. But he did not, as did Hotman 
and the author of the Vindiciae contra tyrannos, hold that such an obligation is compatible with freedom only when the citizen consents to law and government. He would not allow that consent plays any part whatsoever in the obligation to obey. Since, as will appear later, the prince and the law through which he speaks are subject to divine and natural law, for Bodin the ultimate sanction of the individual's liberty, and the guarantee that the necessary restrictions on it in a political society shall be reasonable, is not consent, but the imprescriptibility of divine and natural law.

His treatment of the subject of property is incidental to his defence of the family, and his desire to preserve its integrity. This he saw could only be done by preserving the integrity of its property, threatened by rights of alienation and the depredations of the tax-collector. He therefore, long before either Grotius or Locke, defended private property as sanctioned by divine and natural law, and deduced that the ruler has no right to tax at will [I, viii]. He never asked however, as Grotius and Locke asked, how these rights were distinguished and delimited in the first instance. He simply assumed that the existing state of affairs was sanctioned by the tenth commandment. As a civilian, writing of a society in which property usually meant inherited real estate, he may have assumed as obvious that the rights of individual families went back to an original occupation of res nullius. But however they arose, these rights he regarded as so sacred that the property of the subject cannot be taken from him without his consent, save by legal escheat or confiscation. Presumably he meant that the consent of the Estates was necessary to the imposition of any new tax.

The establishment of the principle that there are certain imprescriptible rights in the individual provided him with the means of distinguishing the rightly ordered state from that which is not so. Tyrannical government is one under which the liberty and property of the subject are arbitrarily invaded, a legitimate government one where the ruler or rulers respect and guarantee them [II, ii]. If then he agreed with Calvin that the state originated in sin, he did not agree with him that in consequence it is merely a machinery for the punishment of sin. He followed up his account of the wickedness of the first rulers by observing that in the face of the threat of enslavement, men were drawn together to form a society whose purpose was the preservation of rights [III, vii]. A true state is therefore a droit gouvernement.

It is clear from his discussion of the term droit that he meant nothing less by it than the whole good of man. He repeats the accepted formula that the body should be disciplined to virtuous activity, and virtuous activity directed to the apprehension of eternal truth. Aquinas would have agreed. But Bodin added that contemplation, or the development of those qualities of mind whereby men distinguish good and evil, true and false, pious and 
impious, is not only the sovereign good of the individual, but also the true end of the state, for he explicitly identified the two. The importance of this modification can hardly be exaggerated, for it brings not only natural virtue, but religion within the sphere of politics [I, i]. He does not however enlarge upon the implications, nor ever discuss the Church as such. But it is clear that he did not mean that the state has an obligation to establish 'true religion', or that it is for the prince to set up an organized Church and compel conformity to it. This is clear from his treatment of the subject of heresy [IV, vii]. He objected to persecution as only too likely to produce a general scepticism about religion. This he thought a disaster of the first importance, for in his opinion any system of beliefs is to be preferred to none. Religion, because it induces reverence and obedience, is the foundation of the commonwealth, and it largely rests with the prince whether it flourishes or not. What the prince must do is to establish conditions under which religion in the general sense is encouraged. Only by toleration of all forms can genuine piety be promoted, and only the prince can implement a policy of toleration. When therefore Bodin makes droit the end of the state, he does not mean, as Aristotle did, that the state is the means to the good life because political activity is the highest exercise of virtue. He meant that the state alone can maintain those conditions under which subjects can individually live virtuous, thoughtful, and pious lives. The best state, he says, is the one in which the greatest number of citizens live such lives.

Bodin was at the same time fully aware of the fact that in this imperfect world all states fall short of this ideal in varying degrees, and pursue not the highest good, but some particular good only, Sparta courage and devotion, Rome justice. As he says, the state must first secure the lives of its citizens before it can consider how they should live virtuously, and the energies of most states are absorbed in the initial effort of survival. In fact, in the ensuing books of the Six books of the Commonwealth the discussion is largely confined to this immediate problem of self-preservation. But as he said in his opening chapter, he did not intend to take Plato as his model and describe an ideal impossible of realization. Like Aristotle, he was looking for the best in the possible, and he was fully aware that as things were, states fell far below the level of what in favourable circumstances they might become. Having defined the ideal, or ultimate goal, his practical intention involved concentrating on what can in fact be achieved.

When he comes to consider the essential structure of the state, he follows Aristotle in holding that the family group, and not the individual, is the unit out of which the commonwealth is made up [I, ii]. He agreed that the family is a natural society held together by the authority of the husband over the wife, the father over his children and the master over his 
servants, all sharing a common means of subsistence. But what he emphasized was its moral and political rather than its economic significance, complaining that Aristotle neglected this aspect of it. He discussed it from the point of view of the father, and the father in his role of ruler rather than in his role of organizer of the common life. This was because, as is clear from all that he has to say about both the origin of the state, and the causes of its destruction, he was convinced that what men chiefly need is discipline to correct their factious and rebellious spirits. Therefore, he wanted to see the authority of the father not only preserved, but strengthened even to the extent of the power of life and death over his dependants, for he saw in that power the only means of training the young in the habit of obedience necessary to be acquired if they were later to exhibit that submission to the ruler proper in a subject [I, iv]. Good citizens are made in the nursery. It is thus its political importance that impels him to defend the authority of parents.

Starting from these ideas of sin and its correction, it is not surprising that he should have seen the state in terms of power [I, viii]. Its distinguishing mark is puissance souveraine, a sovereign power. It is necessarily perpetual and absolute, for any person or persons, within the community or outside it, who can impose any time limits, or restrictions on its competence, must be the true sovereign, and the apparent sovereign only an agent. His admission of lois royales, or fundamental laws of the French monarchy, does not really compromise these statements. The salic law is a rule restricting, not the exercise of sovereignty, but the choice of the person who may exercise it. The denial of the right to alienate royal domain was an application of the principle of Roman law that the one thing a sovereign cannot do is to destroy his own sovereignty, and this, Bodin thought, the impoverishment of the Crown would bring about.

On the other hand the use of the term 'absolute' did not necessarily imply that sovereign power was underived, since jurists were familiar with the Roman theory that the imperium is inherent in the community, and conferred by it on the ruler. But Bodin, though trained in the civil law, rejected this part of it. He did so almost certainly because the doctrine of the popular origin of political authority was already being associated by Huguenot writers such as Hotman, with doctrines of the right of resistance. It was very likely this association which led Bodin to deny that consent to government was any part of natural liberty, or that the obligation to obey depended on such consent being given. Bodin's ideas on the origin of political authority derive not from the civil law but from the Hebrew Scriptures. All power is of God [I, viii]. All right to command is therefore essentially independent of the consent of the commanded. The artificial society of the commonwealth should be modelled on the natural society of the family, and no father is appointed by his children to rule over them. 
The unqualified right to command is therefore the distinguishing mark of the ruler. This characterization of the sovereign in terms of power is one of Bodin's most original conceptions, and marks the break with the traditional view of the king, enshrined in coronation oaths in use everywhere, that he was in virtue of his office essentially the embodiment of justice, and his primary function was to judge his subjects. Such a conception of monarchy was still that commonly held. Louis XII, busy with projects for the codification of law, spoke of himself as 'débiteur de justice à nos sujets'. The same view was taken by so eminent a contemporary of Bodin's as the Chancellor, Michel de L'Hôpital, whose politique views on the French monarchy, expounded in his great speech to the Estates in 1560, were in other ways very much the same as Bodin's. Kings were first instituted, he told them, for the sake of justice, and this remains the essential attribute of the kingly office, as is shown by the representation of the king on the great seal, seated on his throne in the act of judgement.[3] Bodin, while agreeing that all jurisdiction derived from the king, did not even include the exercise of jurisdiction among the attributes of sovereignty, much less make it the distinctive mark, since the king exercises this right indirectly, by delegation [IV, vi]. For him the peculiar and essential mark of sovereignty is the right to make law; it is its unique attribute, for it is the normal means by which the sovereign indicates his commands. Law then is simply the command of the sovereign. This voluntarist conception is underlined by the distinction he makes between law -- that which is commanded -- and right -- that which is equitable. Only the first proceeds from the sovereign.

If law is command simply it includes, as Bodin saw, all activities of the sovereign. There are however certain matters which the sovereign must attend to himself in virtue of his office and not delegate to the subject, as he delegates rights of jurisdiction, and these powers Bodin calls the attributes of sovereignty. First there is included what Locke called the federative power, or sole right of making war and peace, and concluding alliances. Second there is the right to authorize all appointments to public office, whatever the actual procedure in use. Again, as the source of all rights of jurisdiction, the sovereign is the final resort of appeal for all his subjects and in all causes. Finally he has the exclusive right to demand unqualified oaths of submission, for the relations of the subject to his sovereign are unique in that all his other obligations, as vassal of his lord, for instance, are subject to the prior obligation to his sovereign. These rights are inseparable from sovereignty, for the alienation or delegation of any one of them destroys the sovereign.

From these premises Bodin was able to reach that conclusion that he was convinced must be established if any order was to be maintained anywhere. There is no right whatsoever in the subject of rebellion against the 
sovereign he had no part in instituting or of disobedience to the law he had no part in making [II, v]. So long as the king had been regarded as the embodiment of justice, the obligation to obey was conditional on the justice of the command. But once the king was conceived of as an absolute and independent power, the usual grounds of resistance were denied. At the same time Bodin wanted to establish a positive obligation to unconditional obedience. He did so by postulating that political authority was of divine institution. Natural and divine law oblige a man to obey the ruler set over him by God. Much as he might condemn tyranny, he would not allow that the cruellest of tyrants and the most unjust of laws may be resisted. The virtue of the citizen is the virtue of obedience.

So much does Bodin insist on power as the distinguishing mark of the state that he comes very near to saying that it is the existence of a sovereign that constitutes a state. He defines the state in terms of its government, 'a rightly ordered government', and citizenship in terms of subjection, for it is not any rights which he may enjoy that make a man a citizen, but his subjection to a sovereign power [I, vi]. The identity of a state therefore depends on the identity of its sovereign [IV, i]. Every revolution, whether sudden or gradual, which results in the seat of sovereignty being changed involves the foundation of a new state, though laws and institutions remain without alteration. This happened when the slow growth of the power of the Princes converted Germany from a monarchy to an aristocracy. But no revolution in laws and institutions, such as the setting up of Lutheran churches in the Scandinavian states, creates a new commonwealth, if sovereignty remains in the same place. Bodin could not go quite so far as Hobbes and define the commonwealth as a number of individuals united solely by their individual subjection to a common power, for he thought of men as naturally sociable, and any association of men as based on mutual amity even more than on justice [III, vii]. But sharing Hobbes's acute fear of anarchy, he was possessed by the same conviction that the recognition of an absolute sovereign power was the only bulwark against it. Where there is no such power, there can be no political society.

This insistence that effective power was the mark of the state does not mean however that Bodin was the exponent of power politics in the same sense that Machiavelli was. Nor could he have said with Hobbes that there is no distinction of right and wrong, just and unjust, until a sovereign makes laws creating such distinctions. As has already been shown, he included the idea of right, as well as of power, in his definition of the state. Though he distinguished law and equity, it was because of the difference in provenance. The one proceeds from the sovereign and the other from God. But in a rightly ordered society there should be no opposition between them; law should conform to equity. Starting as he did from the conception of an absolute moral order, he was necessarily emphatic that if the sovereign is 
absolute in relation to the subject, he is not so in relation to God. To God, as the author of his authority, he is in all things answerable. The sovereign is not therefore a law unto himself, but the instrument of divine law, bound to make his laws conform to its principles [I, viii]. From the point of view of the oppressed subject, this qualification of the absolute authority of the ruler would seem to be of no practical importance, since no human agent might appoint himself the executor of divine justice. But it was a qualification very generally accepted as of the first importance in the sixteenth century. In the next century it was writers such as Bossuet, or James I and Filmer, rather than Hobbes, who were Bodin's spiritual heirs in this respect.

Bodin however did not intend that the moral sanctions governing the exercise of sovereign power should be unreal. His insistence that the prince must act as the instrument of divine and natural law led him to make considerable qualifications of practical import in the absolutism of a monarch who governs as he should. It is sometimes said that Bodin's ideal was constitutional monarchy, because he advocated the summoning of Estates. It is not so much Estates however which he thought of as tempering the improper exercise of absolute power, for he thought their function purely consultative, but rather the unvarying rule of law based on equity.

This comes out very clearly when in book III he proceeds to analyse the essential structure of government, as a counterpart to his analysis of the essential structure of the state. The inclusion of the term 'rightly ordered government' in his definition of the commonwealth required such an investigation. For government to be efficiently, still more for it to be justly, conducted, three things are necessary, counsel, execution, and assent. The commonwealth should therefore be provided with a 'senate' or council with a constitutional right to advise the sovereign, a magistracy with legal rights of jurisdiction, and Estates which provide a means of communication between subjects and sovereign. A council and Estates are not however a necessary part of the government of the commonwealth. It is highly expedient, but not necessary, for the sovereign to act upon advice. He can act on his own unassisted judgement, and may choose to do so [III, i]. Again, the sovereign need not invite representations from his subjects, nor consult with them in matters of public interest. But again, it is highly expedient for him to do so. Emphatically as he rejected the doctrine that law and government derives from the community, he was fully aware of the practical value of consent in securing obedience. Estates provide the sovereign with the opportunity both of informing himself of grievances, and securing approval for proposed remedies. Such consultation is, however, a matter of policy and not obligation [I, viii and III, vii].

But the case of the magistrates is different. They are indispensable to the 
government of the commonwealth, for though the sovereign is the fountain of justice, he necessarily delegates the exercise of powers of jurisdiction.

The law is his command, but it is not physically possible for him to enforce it personally throughout his dominions, or hear all the suits of all his subjects, without the magistrate as intermediary. It is on the magistrate rather than on the sovereign that the regular functioning of the commonwealth depends. Neither the will of the sovereign, nor the law, can come into operation until the magistrate gives it effect, or as Bodin says, brings it to life [III, v]. He implies that the magistrate has therefore a share in sovereign power, though a strictly subordinate one, for he is bound in obedience to his sovereign, and holds office during pleasure. But because of its indispensability to the functioning of a state, the office pertains to the commonwealth and not to the sovereign, who only has the right of the provision of persons; and when the magistrate is given discretionary powers, and is not bound to apply the letter of the law automatically, he does so in right of his office, and not simply as the agent of the sovereign. $\mathrm{He}$ therefore shares the sovereign's responsibility to divine and natural law, and is bound by the principles of equity in all his independent actions.

So Bodin sums up his account of the government of the commonwealth, 'a state cannot fail to prosper where the sovereign retains those rights proper to his majesty, the senate preserves its authority, the magistrates exercise their legitimate powers, and justice runs its ordinary course'. For a prince to govern in any other manner is for him to risk becoming a tyrant.

Perhaps an even more serious check on the arbitrary exercise of absolute power was the obligation of the sovereign to keep his 'covenants' with his subjects. Bodin deduces this obligation from the subjection of the prince to divine and natural law. By a 'covenant' he means any law which is the outcome of an agreement between the sovereign and his subjects. He gives as illustration the promises of redress of grievances, given to the Cortes by the Spanish kings on various occasions, in return for a grant of taxation. All such agreements he thought binding, and he distinguished them from the laws which proceed from the sole will of the prince and so can be abrogated by him at pleasure [I, viii]. Moreover his insistence that the prince may not tax without consent provides occasions tor the making of such covenants, as his example of the Spanish kings shows.

It is clear then that in a rightly ordered commonwealth, governed according to the principles of divine and natural law, there is necessarily an absolute power, but it should not function as an arbitrary one. Much as he learned from Machiavelli, he did not share his faith in the unfettered rule of men of ability. His ideal was a state in which, as Harrington would have said, there is the regiment of laws and not the regiment of men. 
At the same time, though in the rightly ordered commonwealth there is the rule of law, divine, natural, and positive, a political society does not cease to be a true commonwealth if these conditions are violated. It is still a true commonwealth if it is characterized by a sovereign power. This becomes clear when Bodin turns from the consideration of the state to states, or the various forms in which the state can be embodied. Until the Italians started comparing the workings of despotisms and popular governments as they knew them in Italy, no one since ancient times had thought of analysing the forms that the state can take. It is true that in the later middle ages knowledge of the Politics familiarized scholars with Aristotle's six pure types. But since the speculations thus provoked had no roots in the practical politics of those times, nothing of importance was added to what Aristotle had to say. The Italians on the other hand confined themselves to the two types they knew, and did not attempt an exhaustive analysis of all possible forms. What is remarkable about Bodin's handling of the theme is that it is both exhaustive and freshly observed. He took the greatest care to find as exact a description as possible of the actual situation and therefore, based as it was on individual observation, there was nothing merely derivative in his account.

He started by reducing Aristotle's six types to three, monarchy, aristocracy and democracy. because, as he saw, if the existence of a sovereign power is the mark of a state, this is a matter of fact, and provides no criterion for distinguishing good and bad states. All that can be distinguished in fact is the location of sovereign power. With his eye on the actualities of the situation, he defined aristocracy not as the rule of the few, but the rule of a minority group, and democracy not as the rule of the many, but the rule of a majority of the whole body. The mixed constitution, so much admired by most of Aristotle's readers, especially in the sixteenth century, he rejected as impossible of existence. That which is absolute cannot be divided. An absolute power must be unique or it is no power at all [II, i].

Right as he might be in this respect, he would seem to have been sacrificing one great advantage. Constitutions, especially European constitutions, were very various. The supposition of mixed constitutions provided a formula for differentiating a great number of permutations and combinations. Bodin however solved the problem in another way. In the first place he made a distinction in the way sovereign power is exercised. Each type can operate tyrannically as a mere exercise of arbitrary power, regardless of the claims of justice or the rights of the subject. Or it can operate despotically as the rightful exercise of an arbitrary power over subjects conquered in a just war. Or it can operate legitimately in accordance with the principles of divine and natural law, safeguarding the inherent rights of subjects.

Bodin appears here to be doing what he had just said could not be done, 
distinguishing states by a standard of value and not simply by a matter of fact. It is not only that the terms 'tyrannical' and 'legitimate' imply condemnation in the one case and approval in the other. In the one the principles of divine and natural law, which are the mark of the rightly ordered government, are observed, and in the other they are not. Bodin would probably have answered that he is not here classing states according to the particular ends they pursue, but only according to the mode of their operation. Nevertheless one cannot get over the fact that another element than purely constitutional factors is brought in. It is a particular example of his tendency to mingle judgements of fact with judgements of value without distinguishing them.

Much more original was the distinction he made in the second place between the sovereign and the government, or machine through which the sovereign operates. Each of the three fundamental types of commonwealth can be provided with a form of government normally characteristic of one of the other two [II, ii]. By this test ancient Rome was a democracy governed aristocratically, and contemporary France, England, and Spain monarchies governed democratically. This analysis was, he claimed with justice, new. Moreover it was surely much more true to the facts than the old doctrine of mixed constitutions.

Bodin gave so much time and space to the meticulous examination of the structure of actual states because the ultimate purpose of his analysis was a practical one. He wanted to find out the secret of stability in a politically unstable world. Being a sixteenth-century Frenchman, and a patriot, his decision was inevitably in favour of monarchy [VI, iv]. The essential mark of sovereignty is the power to command, and commands, as he says, must proceed from a single will. Collective sovereignty belongs to the realm of ideas rather than of actualities, so that in times of crisis, when immediate and decisive action is necessary, all types of commonwealth tend to revert temporarily to monarchy by the institution of a dictatorship, or some such expedient. Moreover, since he rejected the necessity of consent to government, the important thing about government in his view is not that it should be approved, but that it should be well-advised. A king alone can consult whom he wills, and be governed by the advice of the wiser, and not just the more numerous part. Democracies where the opposite is true, and it is the opinion of the majority that prevails, he thought the least stable form of commonwealth because the majority of men include the ignorant, passionate, and gullible. Aristocracies he also thought insecure because perpetually threatened by dissensions, dissension between the governed and the governing class, and struggles for power within the governing class itself. Only in a monarchy are conditions to be found favourable to that alliance of unity with wisdom which makes the proper exercise of power possible. 
Defects however can be mitigated, if not eliminated, if the form of the government is different from that of the commonwealth. The democratic Roman Republic lasted so long because governed aristocratically, in that office was largely confined to the patrician class. It was much vexed by civil strife, but it exhibited a measure of wisdom and discipline in the conduct of affairs which could not have been expected from the plebs, and which secured its long survival. But with the example of the three great western monarchies before his eyes, he was convinced that the most stable form is a monarchy governed democratically, that is to say where the king consults the estates, and all subjects are eligible to office, and it is not exclusive to any one class. Such a state has both the strength that comes from unity, and the strength that comes from common consent.

Not that Bodin thought that it was possible to establish at will those forms perceived to be the most stable. On the contrary he did not consider that the particular forms of states are a matter of human choice and contrivance at all, but rather the inevitable product of environment, or 'climate' as he calls it $[\mathrm{V}, \mathrm{i}]$. His doctrines were a deduction from still current medieval physiological theories about the close inter-relation of mind and body. Temperature and humidity determine physique, and physique determines mental and moral aptitudes. This being so it is obvious that the forms of law and government must also be shaped by these unalterable conditions. Rather surprisingly for so systematic a thinker he makes no attempt to bring his argument full circle, and work out a connection between the three climates he distinguished, frigid, temperate, and torrid, and the three fundamental types of commonwealth. It would have meant much forcing of the facts about the distribution of political forms in Europe to make them fit into a neat pattern of this sort. He preferred to leave these ends loose, and confined himself to such scattered observations as that the vigour and independence of mountain peoples, which comes from the severity of the climatic conditions, explain why the Swiss and the Florentines have developed democratic forms of government, whereas the more relaxing effect of damp and marshy country predispose Venetians to submit to the rule of an aristocracy.

Forms of government and of law must be judged therefore by relative and not by absolute standards. The savage penal code, and warlike policies appropriate to the physically vigorous, brave but stupid northern races are altogether unsuited to the delicate, timid, imaginative, and subtle southerner. Diplomacy is the effective weapon of their advancement. Bodin had said at the beginning of the Six books of the Commonwealth that no state pursues the good life absolutely, but always some particular and partial good. His doctrine of the influence of environment meant that it is in the nature of things that this should be so.

Here a modem reader would be satisfied that Bodin had made his point and 
need carry the argument no further. But Bodin meant by 'climate' something much more all-pervasive than temperature, humidity, and the he of the land, though he included all these things. When he subordinated the commonwealth to divine and natural law he did not only mean that its laws and its government ought to conform to a moral order. He also meant that it had its necessary place in a physical universe subject to invariable natural laws proceeding from God as first cause. It is only when his cosmological ideas are taken into consideration that the full significance of his relativist views on politics is to be appreciated.[4] His system was medieval, for he deliberately rejected Copernicus in the Novum Theatrum Naturae, and adhered to the traditional view based on Aristotle's physics. That system was necessarily astrological. If Aristotle's premises were accepted, first that the universe consists of a material core, the earth and its atmosphere, enclosed within an immaterial envelope, the heavens; and second, that matter is in itself inert and formless; it followed that its myriad forms, and the unceasing transmutation to which it is subject, must proceed from immaterial agents external to it. These agents can only be the stars. Their perpetual and complex revolutions in their circular orbits round the earth are the cause of all phenomena and all change of any kind. All things, from a grain of corn to a commonwealth, are moulded by the place and time of their occurrence, and their life-histories governed by the movement of the heavens. Hence his view of history as the record of recurrences. The historical process must be cyclic rather than evolutionary since it proceeds from the circular motion of the heavens.

It was therefore natural and inevitable that his treatment of history should seem from our point of view to lack perspective. He agreed with Machiavelli that history repeats itself: democracy in ancient Rome, or in the Forest Cantons of contemporary Switzerland was a manifestation of a fixed and constant type. But whereas Machiavelli derived his cyclic view of the historical process from his doctrine of the constancy of human nature, Bodin derived it from the recurrent pattern of events inherent in the cosmic process. It will be observed that Bodin's ideas about the relativity of laws and institutions have a spatial rather than a temporal reference. As one moves through space they differ, according to the different figure of the heavens enclosed within their horizon. But as one moves through time one keeps on coming upon the same phenomena, according as the stars repeat their revolutions.

This is not to say that he believed in an order of necessity in human affairs. The search for the principles of practical wisdom in politics which dominates so much of the Six books of the Commonwealth presupposes the opposite. Bodin held the orthodox view that the will, being immaterial, is free of those celestial forces that mould matter. If a man cannot change his environment and the influences to which he is subject, he can make the best 
or the worst of his situation. The increasing disorder of the world in which he lived convinced Bodin that statesmen were making the worst of it, largely through ignorance, and states, as do natural bodies, were perishing untimely from violent disorders.

Books IV and V therefore are devoted to the problem of the preservation of the commonwealth, or rather, of the sovereign power which is its constitutive principle. It takes the form of a discussion of revolutions, what induces them, and what precautions are necessary to avoid them, for it must be remembered that for Bodin a revolution which removes the seat of sovereignty involves the destruction of one state and the foundation of a new one. Bodin was always drawing conclusions about what ought to be done, but these two books are entirely devoted to the applied science of politics. $\mathrm{He}$ considers such questions as the laws governing the distribution of property $[\mathrm{V}$, ii], the rules relating to eligibility for office and the terms of appointment [IV, iv], the attitude to be taken to political parties, or to professional and other associations of citizens [IV, vii and III, vii], or the best way of securing the state against attack $[\mathrm{V}, \mathrm{v}]$. He lays down a few rules of general application. Patrimonial estates should not be confiscated, whatever the needs of the exchequer [V, iii]. Divisions among citizens such as are embodied in political parties should never be encouraged, but peaceful associations such as trade-guilds should [III, vii]. Office should never be sold [V, iv].

But nearly all his conclusions are, as is to be expected, relative to the type of commonwealth to be preserved, for as he says, states of opposite tendencies require opposite policies. For instance, in a democracy office must be open to all and of short duration to preserve an even distribution of power by equal and rapid rotation. If this is not secured democracy perishes. By parity of argument in an aristocracy eligibility must be confined to the ruling class. In the case of monarchy, however, since it is not based on the rule of a class, the king can choose his officers where he will, and be guided solely by convenience in fixing the terms of appointment, long in subordinate positions where experience is useful, short in the high offices of state where long enjoyment of power makes a mere subject too mighty.

He owed much in these two books to a similar discussion in the Politics. But he was an independent observer of contemporary politics, and not only did he apply what Aristotle had to say to conditions in the sixteenth century, but recognized problems which did not exist for Aristotle. Aristotle suggested his treatment of the subject of tyranny. But such discussions as those on treatment of political factions, or the arming of the subject, derived from his own observation or reading. This preoccupation with contemporary problems is a result of his didactic intentions. As has been said already, 
he wished to remedy, not just analyse, the causes of disruption. He was addressing himself to statesmen, and there were two lessons he wished to impress on them. First, that just because a commonwealth is the outcome of circumstances, preconceived notions about how it should be governed are useless and even mischievous. The ruler must start with a thorough understanding of the particular situation with which he has to deal, since fundamentally he cannot change it. And second, having such knowledge of the situation, he must then know what experience has shown to be the appropriate way of dealing with it.

The discussion of the means of preservation of the different kinds of commonwealth, when taken in conjunction with the initial account of the commonwealth as such, raises considerable difficulties. What ends did Bodin really think the state served? In book I it is said that it exists to promote the good and virtuous life for its citizens. A commonwealth is contrasted with a band of robbers, for one is based on justice and the other on violence. He also said that having determined the end, the means to its realization would then be considered. But the argument does not develop in this way. It is not means to the end of virtue in the citizen which are subsequently discussed, but means to the end of the preservation of the state, regardless of its character.

He had of course pointed out in book I that a state must live before it can live well, and this concentration on the immediate problem of survival rather than on the ultimate purpose of the good life does not in itself create any difficulty. But he not only includes tyranny among the true types of commonwealth, but considers how it may best be preserved. Since tyranny is by definition that form of the commonwealth in which divine and natural law is set at defiance, it is difficult to see why he should have recognized it as a commonwealth while rejecting a robber-band, or how it is to be reconciled with the definition of the state as a rightly ordered government.

His inconclusiveness on this crucial point was a consequence of what was characteristic of much of his argument, a tendency to pass from a discussion of what is right to a discussion of what is necessary or expedient, without apparently being aware of the shift of ground. An example has already been noticed in his analysis of the fundamental types of commonwealth. Another is the criteria appealed to in determining the best form of commonwealth [VI, iv]. Or again, it is never quite clear whether he insisted on discipline because it was conducive to virtue, or because it was a condition of political stability. His hesitation arose from the fact that he saw the state in the first place as the possible, and only possible, instrument of the good life on earth. He also saw that to be this it must be an effective power. Thinking of what the state might be he gave it by definition a moral purpose. Thinking of how necessary it is, he accepted any effective 
organized power as a true state. The contradiction was never resolved. In the last analysis he thought any form of polity, however tyrannical, better than anarchy, just as he thought any system of beliefs, however crude and cruel, better than atheism. Therefore the preservation of some sort of state must in all circumstances be secured.

The whole work concludes with a chapter on justice. This would seem at first glance to be a return at the last to the theme of the rightly ordered commonwealth described at the beginning, as distinct from the efficiently governed one, which subsequently occupied his attention. In book I, when illustrating the partial aims of all particular states, he put Rome highest because her achievement was justice. The whole book therefore closes on the suggestion that the best realizable right order which actual states can hope to achieve is not the whole good of man, but that modest degree of it which is called justice. What he meant by the term is therefore of some importance.

In the earlier part of the Six books of the Commonwealth when he is discussing the commonwealth as such, he not infrequently uses the term 'natural justice', without however explaining what he meant by it. The context generally suggests however that he meant respect for the rights of the subject to his liberty and property. In this last chapter on the other hand it is political justice and not natural that he is talking about. He had noticed the difference when he observed that Plato thought of justice as a philosopher and not as a jurist. In this last chapter Bodin is speaking as a jurist. He defines it in legal terms, as the principle upon which rewards and punishments are distributed in the commonwealth, that is to say the working of the criminal law, and the administration. But whereas natural justice is presumably in his view constant and universal, here the proper order of justice is relative to the type of commonwealth. Commutative justice, or the strictly equal distribution of honours and penalties preserves a democracy but would destroy an aristocracy. Conversely distributive justice, or award in accordance with the quality of persons, safeguards an aristocracy but would corrupt a democracy. In a monarchy where a more elastic social system is possible than in either of the other two types, since in it classes are at once distinguished and yet not mutually exclusive, harmonic justice is the appropriate form since by it honours are given not in accordance with the status of persons, but with their particular suitability [VI, vi].

This treatment of the theme of justice, therefore, does not really bring the argument back to the state considered as the instrument of the good life. It is true that justice here means right order in the commonwealth, but it is the right order that preserves it as a type, rather than any embodiment of universal moral principles. As he said, states must live before they can 
live well, and the discussion in book IV of the causes of revolution made it clear that they do not find it so easy to live. The whole work ends on this note, how may their survival be assured.

However, the theme of book I, that the state exists to promote virtue in its citizens, is not completely lost sight of, and at one point in the final book he returns to the problem of the pursuit of higher ends. Every state, he says, ought to undertake the moral discipline of its citizens, such as was exercised in pagan Rome by the censors. In the modem state he regarded it as the function of priests and ministers of religion, [VI, i]. The Church has a duty and a place within the state. It is clear that when he included true religion in that total good which it is the state's purpose to promote, he did not only mean that the prince should free the practice of one's beliefs from legal restrictions. He also meant that the clergy have a necessary function in the disciplining of the citizen. They are not however solely responsible for this discipline. It is a duty incumbent on the sovereign to use such opportunities as he has to the same end. Surprisingly enough he thought the proper management of taxation a suitable means. In spite of the chronic inadequacy of the revenues in France in his day, he clung to the conviction that the king ought to be able to 'live of his own', and that taxes were an extraordinary expedient which ought never to be allowed to establish themselves as an ordinary source of revenue. Nevertheless, he had to recognize that there are crises for which the ordinary revenues do not suffice. On such occasions, when taxes must be imposed, they should be on luxury articles, not because that involves taxing the rich and the rich should pay, or because it is economically sound, but because the most effective way of checking self-indulgence and vicious habits is to make them expensive [VI, ii].

As has been shown, the Six books of the Commonwealth was an immediate success, and a much read book for about fifty years after its appearance. Nevertheless from Bodin's point of view it was perhaps only a partial success. Although his doctrine of the relativity of political institutions has attracted much attention in present times, Bodin wholly failed to impress his contemporaries as a student of politics. Rulers did not carry round a copy of his book as they were reported to do with the Prince. Apart from its immense length, it was not very digestible. The form is repellent to all except the determined reader. Bodin buried his conclusions under a mass of evidence and long scholarly discussions of its interpretation. The presentation was formal and elaborate in an old-fashioned way. The chapters were very long, unparagraphed, and with few marginal headings to indicate the succession of subjects of discussion. Emphatically, not the sort of reading that men of affairs take up. He was read by people whose interest in politics was speculative rather than practical. What attracted them was his doctrine of sovereignty, his analysis of forms, and his defence of monarchy. 
Everyone writing after Bodin, by direct or indirect influence, repeats what he has to say in whole or in part on these subjects. Hobbes, the royalist writers, and Locke all assume that the essence of sovereignty is the authority to make law, and attribute to the sovereign the powers which he does. Hobbes takes over his analysis of essential forms, the royalists his defence of monarchy on grounds of expediency, and Filmer repeats the whole comparative discussion of the characteristics of each form. Even Harrington, who belonged to the school of thought that Bodin rejected, and ascribed final authority to the people, analysed government into the senate proposing, the magistrate executing, and the people resolving. This part of his book was indeed almost too convincing. Once his doctrine of sovereignty was accepted as common form, his book was no longer kept alive by being a subject of controversy. On the other hand the later part suffered from the opposite disadvantage, neglect. His scholarly readers were not so interested in the discussion of means as of ends. Moreover the fact that he based his doctrine of environment on a cosmological system which was on the point of being abandoned at the very time he was writing probably contributed to the oblivion which was the fate of this part of his work. Montesquieu could claim that the Esprit des Lois was a work which had no parentage.

It was a long time before anyone else attempted to survey so immense a field of political experience, and to carry any further his enquiry into the meaning of the variety of political forms and institutions in all places and at all times. No one, not even Montesquieu, emulated the grandeur of his design. One had to be as near the middle ages in time, and in spirit, as Bodin was, to think and write of the state in relation to the cosmic process, at once rooted in it and reflecting it. He concluded his defence of monarchy with the same argument as Dante and his kind had used. The microcosm should reflect the macrocosm, and thus. since the universe is subject to the sole and sovereign majesty of God, so the commonwealth should be subject to the sole and sovereign majesty of the prince [VI, iv].

The Six books of the Commonwealth marks the transition from specifically medieval to specifically modem ways of political thinking. It at once recorded that process and assisted its accomplishment. His scholarship combined the methods of the old learning with the interests of the new. He asked new questions because he perceived new problems. He recognized the emergence of the state as the all-important and all-powerful instrument of men's fate. But he could not, as could Machiavelli, rid himself of the belief in a universal order of absolute values, in which the state still had a place. His book is all the more interesting because the transition is not perfectly accomplished. This comes out in his inability to make a clear separate of right and fact. He could neither say consistently with the schoolmen, let us consider things as they ought to be if the purposes of God are to be accomplished, or with Machiavelli, let us consider things as they 
must be if men are to have what they desire. Because he was an acute and original observer he was able to analyse the state, its marks, its types, its functions, with clarity. But it is not finally clear whether he still thought its purpose was to make men good by acting as the instrument of a higher law, or had begun to think it existed in its own right to afford them security.

\section{TRANSLATOR'S NOTE}

An abridgment of an important work, to be justified, must preserve not only the whole of the essential argument, but also its characteristic proportions. Closely argued and economically written books are therefore not susceptible of such treatment without suffering loss or distortion. The Six books of the Commonwealth, however, is marked by great elaboration because of the method of demonstration. Bodin's aim to construct a universal science of politics by surveying all the relevant facts and opinions required that this survey should be exhaustive. He tried to make it so. The definition of a citizen is only established after all the descriptions he knew have been discussed, and tested by reference to the facts. An observation on the instability of Florentine politics leads to a recital of the whole course of the city's history from the middle of the thirteenth century -- and so on and so forth. If one is treating the Six books of the Commonwealth as a document of sixteenth-century scholarship, none of this material can be jettisoned. But if it is taken as a book on political science much of it can, for it is not all necessary to the development of the argument. On the contrary, the very wealth of this illustration gives an impression of confusion that Bodin does not deserve. His book is in fact carefully planned as a whole, and however long his parentheses, he always returns to the argument at the point where he broke off. If much of this illustrative material is discarded the main shape of the argument emerges clearly and coherently. This has been the principle of selection in this abridged version, though sufficient reference to past and present political actualities has been preserved to show how he established his conclusions.

Bodin's prose is not easy to translate. The problem is partly one of style and partly one of vocabulary. His sentences are long, elaborate, loosely constructed and elliptical. It would take a Sir Thomas Hoby to convey their quality. No attempt has been made to do this, but only to convey the sense. Though the result may make easier reading, much of the weightiness and force of the original is inevitably lost. But no translation, however inadequate, could fail to preserve one characteristic of the original, and that is the sound of a voice arguing, for this is not just a matter of style, of the way Bodin writes, but of the way he thinks. Difficulties over his vocabulary arise because it was designed to express the actualities of sixteenth-century politics, especially in France, and where there are no 
English counterparts, it is hard to find English equivalents. The distinction he makes between cité and république for instance describes the situation in France but bears no relation to conditions of English political organization. In case of such special difficulties a note has been added. République has been translated commonwealth to avoid the suggestion of a specific form of constitution that republic conveys in English.

Footnotes have been kept to a minimum. Bodin's method of demonstration involves constant reference to the literature of law, philosophy, and history. It has been assumed that his classical and biblical references need no elucidation. Only his references to the more obscure incidents of contemporary politics have been explained, for here his encyclopaedic reading had made him familiar with the bye-ways that are not common knowledge. Discussion of his accuracy in using his sources must however lie outside the scope of a book in which only fragments of them are incorporated.

\section{BIBLIOGRAPHICAL NOTE}

Texts.

A collected edition of Bodin's works is in preparation. Jean Bodin. OEuvres philosophiques, texte établi, traduit, et publié par P. Mesnard (Corpus général des philosophes français). Of this series the first volume has appeared, Methodus ad facilem historiarum cognitionem (Paris, 1951). (This is prefaced by the most recent biography.)

For the Six books of the Commonwealth only sixteenth- and seventeenth-century editions are at present available. An abridged version by J. C. de Laire was published in 1755. Authorities.

H. J. L. Baudrillart, Jean Bodin et son temps (Paris, 1853). R. Chauviré, Jean Bodin, auteur de la République (Paris, 1914). E. Hancke, Bodin. Studien über die Begrijf der Souveränitat (Breslau, 1894). A. Garosci, Jean Bodin, Politica e diritto nel rinascimento francese (Milano, 1934).

E. Fournol, Bodin, prédécesseur de Montesquieu (Paris, 1896). J.

Moreau-Reibel, Jean Bodin et le droit public comparé dans ses rapports avec la philosophie d'histoire (Paris, 1933). B. Reynolds, Proponents of limited monarchy in sixteenth century France.

François Hotman and Jean Bodin (Columbia University Studies in History, No, 334). (New York, 1931). See also:

J. W. Allen, Political Thought in the Sixteenth Century (London, 1928). P. 
Mesnard, L'Essor de la philosophic politique au 16è siècle (Paris, 1936). G. H. Sabine, A History of Political Theory (London, 1937). G. Weill, Les théories sur le pouvoir royal en France pendant les guerres de religion (Paris, 1891).

1. This is most easily consulted in the translation by B. Reynolds (Columbia University Records of Civilization), New York, 1945.

2. This was first published, in an incomplete form, by Guhrauer in 1841. L. Noack published a complete version, Colloquium Heptaplomeres lie abditis rerum sublimium arcanis (Schwerin, 1857). An incomplete French version was published by R. Chauviré in 1914.

3. P. Duféy. Michel de L'Hôpital: OEuvres complètes (Paris, 1824-26), Vol. I, No. 4.

4. For a fuller account of this relationship, see my article, 'Jean Bodin and the medieval theory of climate', in Speculum, Vol. XXVIII, No 1, Jan. 1953. 


\section{BOOK I}

The Final End of the Well-ordered Commonwealth [CHAPTER I]

A COMMONWEALTH may be defined as the rightly ordered government of a number of families, and of those things which are their common concern, by a sovereign power. We must start in this way with a definition because the final end of any subject must first be understood before the means of attaining it can profitably be considered, and the definition indicates what that end is. If then the definition is not exact and true, all that is deduced from it is valueless. One can, of course, have an accurate perception of the end, and yet lack the means to attain it, as has the indifferent archer who sees the bull's-eye but cannot hit it. With care and attention how ever he may come very near it, and provided he uses his best endeavours, he will not be without honour, even if he cannot find the exact centre of the target. But the man who does not comprehend the end, and cannot rightly define his subject, has no hope of finding the means of attaining it, any more than the man who shoots at random into the air can hope to hit the mark.

Let us consider more particularly the terms of this definition. We say in the first place right ordering to distinguish a commonwealth from a band of thieves or pirates. With them one should have neither intercourse, commerce, nor alliance. Care has always been taken in well-ordered commonwealths not to include robber-chiefs and their followers in any agreements in which honour is pledged, peace treated, war declared, offensive or defensive alliances agreed upon, frontiers defined, or the disputes of princes and sovereign lords submitted to arbitration, except under the pressure of an absolute necessity. Such desperate occasions however do not come within the bounds of normal conventions. The law has always distinguished robbers and pirates from those who are recognized to be enemies legitimately at war, in that they are members of some commonwealth founded upon that principle of justice that brigands and pirates seek to subvert. For this reason brigands cannot claim that the conventions of war, recognized by all peoples, should be observed in their case, nor are they entitled to those guarantees that the victors normally accord to the vanquished.... 
It is true that we see brigands living amicably and sociably together, sharing the spoil fairly among them selves. Nevertheless the terms amity, society, share cannot properly be used of such associations. They should rather be called conspiracies, robberies, and spoliations. Such associations lack that which is the true mark of a community, a rightly ordered government in accordance with the laws of nature. This is why the ancients define a commonwealth as a society of men gathered together for the good and happy life. This definition however falls short on the one hand, and goes beyond the mark on the other. It omits the three principal elements of a commonwealth, the family, sovereign power, and that which is of common concern, while the term 'happy', as they understood it, is not essential. If it were, the good life would depend on the wind always blowing fair, a conclusion no right-thinking man would agree to. A commonwealth can be well-ordered and yet stricken with poverty, abandoned by its friends, beset by its enemies, and brought low by every sort of misfortune. Cicero saw this happen to the city of Marseilles in Provence, yet he thought it the best-ordered and most civilized city, without exception, of any in the world. On the same showing the commonwealth that is well-situated, wealthy, populous, respected by its allies, feared by its enemies, invincible in war, impregnable, furnished with splendid buildings, and of great reputation, must be considered well-ordered, even if given over to every wickedness and abandoned to vicious habits. But there is surely no more fatal enemy to virtue than worldly success of this sort, fortunate as it is accounted to be, for they are contraries not to be reconciled. Therefore we do not include the term 'happy' as an essential term in our definition. We aim higher in our attempt to attain, or at least approximate, to the true image of a rightly ordered government. Not that we intend to describe a purely ideal and unrealizable commonwealth, such as that imagined by Plato, or Thomas More the Chancellor of England. We intend to confine ourselves as far as possible to those political forms that are practicable. We cannot therefore be blamed if we do not succeed in describing the state which is rightly ordered absolutely, any more than the pilot, blown out of his course by a storm, or the doctor defeated by a mortal disease, is to be blamed, provided he has managed his ship or his patient in the right way.

The conditions of true felicity are one and the same for the commonwealth and the individual. The sovereign good of the commonwealth in general, and of each of its citizens in particular lies in the intellective and 
contemplative virtues, for so wise men have determined. It is generally agreed that the ultimate purpose, and therefore sovereign good, of the individual, consists in the constant contemplation of things human, natural, and divine. If we admit that this is the principal purpose whose fulfilment means a happy life for the individual, we must also conclude that it is the goal and the condition of well-being in the commonwealth too. Men of the world and princes however have never accepted this, each measuring his own particular well-being by the number of his pleasures and satisfactions. Even those who have agreed that the sovereign good of the individual is contemplation, have not always agreed that the good of the individual and good of the commonwealth are identical, and that to be a good man is also to be a good citizen. For this reason there has always been a great variety of laws, customs, and policies attendant on the desires and passions of princes and governors. Since however the wise man is the measure of justice and of truth, and those reputed wise have always agreed that the end of the individual and the end of the commonwealth are one, without distinction of the good man and the good citizen, we also must conclude that contemplation is the end and form of the good to which the government of the commonwealth should be directed.

Aristotle was not always consistent in what he had to say on the subject. At times he compromised with the views of various people, coupling now riches, now power, now health, with virtue, in order to take into account commonly received opinions. But in moments of greatest insight he made contemplation the height of felicity. It may have been similar

considerations which prompted Marcus Varro to say that human felicity springs from the union of action and contemplation. To my mind this is so, because whereas the well-being of a simple organism may be simple in character, that of a dual organism, composed of diverse elements, must itself be of a dual nature. The well-being of the body comes from health, strength, vigour, and the beauty of well-proportioned members. The well-being of the active principle of the soul, which is the link between body and soul, consists in the subordination of appetite to reason, in other words, the exercise of the moral virtues. The well-being of the intellective part of the soul lies in the intellectual virtues of prudence, knowledge, and faith. By the first we distinguish good and evil, by the second truth and falsehood, and by the third piety and impiety, and what is to be sought and what avoided. The se are the sum of true wisdom, which is the highest 
felicity attainable in this world.

If one turns from the microcosm to the macrocosm, it follows by parity of argument that the commonwealth should have a territory which is large enough, and sufficiently fertile and well stocked, to feed and clothe its inhabitants. It should have a mild and equable climate, and an adequate supply of good water for health. If the geography of the country is not in itself its best defence, it should have sites capable of fortification against the danger of attack. These are the basic needs which are the first objects of concern in all commonwealths. These secured, one looks for such luxuries as minerals, medicinal plants, and dyes. Offensive weapons must also be provided if one would extend one's frontiers and subjugate the enemy, for the appetites of men being for the most part insatiable, they desire to secure great abundance not only of what is necessary and useful, but of what is pleasant merely, and redundant. But just as one does not think of educating a child until it is grown and capable of instruction, so commonwealths do not concern themselves with the moral and mental sciences, still less with philosophy, till they are amply furnished with all that they regard as necessities. They are contented to cultivate that modest degree of prudence which is sufficient for the defence of the state against its enemies, the prevention of disorders among its subjects, and the reparation of injuries.

A man of good disposition however who finds himself well provided with the necessities and comforts of life, secure and at peace, turns away from unworthy companions and seeks the society of wise and virtuous men. When he has purged his soul of troubling passions and desires, he is free to give his attention to observing his fellows, and interests himself in the difference that age and temperament makes between them, the causes of the greatness of some and the failure of others, and of the fluctuations of states. From men he turns to the contemplation of nature, and considers the great chain of being, minerals, plants, and animals in their hierarchical order, the forms, qualities, and virtues of all generated things, and their mutual attractions and repulsions. From the world of material things he moves forward to the contemplation of the immaterial world of the heavens, where the splendour, beauty, and power of the stars is manifested in their proud, remote, and majestic movements, comprehending the whole universe in a single harmony. The ecstasy of this vision inspires him with a perpetual 
longing to penetrate to the first cause and author of this perfect creation. But there he must pause, for the greatness, the power, the wisdom, and goodness of the Supreme Being, being infinite, must for ever remain inscrutable in its essence. By such a progression a wise and thoughtful man reaches the concept of the one infinite and eternal God, and thereby as it were attains the true felicity of mankind.

If such a man is adjudged both wise and happy, so also will be the commonwealth which has many such citizens, even though it be neither large nor rich, for in it the pomps and vanities of proud citizens, given over to pleasure, are contemned. But it must not be assumed from this account that felicity comes from a confusion of many elements. Man is made up of a mortal body and an immortal soul, but his final good pertains to the more noble part of himself... For though those activities such as eating and drinking by which life is supported are necessary, no thoughtful man finds in them his sovereign good. The habit of good deeds is of the first importance, for the soul that is not illumined and purified by the moral virtues cannot enjoy the fruits of contemplation. The moral virtues are therefore ordained to the intellectual. Felicity cannot be found in that imperfect state in which there is still some good yet to be realized; that which is less noble is ordained to that which is more noble as its final end, body to spirit, spirit to intellect, appetite to reason, living to right living. Therefore when Varro found felicity in both contemplation and action, he would have done better, in my opinion, to have said that a man has need of both action and contemplation in this life, but that bis sovereign good lies in contemplation. Nevertheless it is certain that a commonwealth is not rightly ordered which neglects altogether, or even for any length of time, mundane activities such as the administration of justice, the defence of the subject, the provision of the necessary means of subsistence, any more than a man whose soul is so absorbed in contemplation that he forgets to eat and drink can hope to live long....

The same principles hold good for the well-ordered commonwealth. It is ordained to the contemplative virtues as its final end, and those things which are least in order of dignity come first in order of necessity. Those material things necessary to the sustenance and defence of the subject must first be secured. Nevertheless such activities are ordained to moral activities, and moral activities to intellectual, or the contemplation of 
the noblest subjects within the scope of men's imaginations. Thus we see that God allotted six days for all those labours to which the greater part of man's life is dedicated. But He ordained that these labours should cease on the seventh day, and He blessed it above all other days as the holy day of rest, so that men might then have leisure to contemplate His works, His law, and His glory. Such is the final end of well-ordered commonwealths, and they are the more happy the more nearly they come to realizing it. For just as there are degrees of felicity among men, so are there among commonwealths, some greater, some less, in accordance with the end which each sets out to attain. It was said of the Spartans that they were courageous and magnanimous, but for the rest unjust and perfidious, if they could thereby further the public interest. The sole purpose of their laws, their customs, their institutions was to make men brave and indifferent to hardship and pain, contemptuous of ease and pleasure, and totally devoted to the state. The Roman Republic on the other hand was distinguished for its justice, and surpassed that of the Spartans, for its citizens were not only magnanimous, but justice was the mainspring of all their actions.

In treating of the commonwealth we must therefore try and find means whereby it may come as near as possible to realizing the felicity we have described, and conforming to the definition we have postulated. Let us continue with the terms of the definition and pass on to the family.

\section{Concerning the Family [CHAPTERS II-V]}

A FAMILY may be defined as the right ordering of a group of persons owing obedience to a head of a household, and of those interests which are his proper concern. The second term of our definition of the commonwealth refers to the family because it is not only the true source and origin of the commonwealth, but also its principal constituent. Xenophon and Aristotle divorced economy or household management from police or disciplinary power, without good reason to my mind ... I understand by domestic government the right ordering of family matters, together with the authority which the head of the family has over his dependants, and the obedience due from them to him, things which Aristotle and Xenophon neglect. Thus the well-ordered family is a true image of the commonwealth, and domestic comparable with 
sovereign authority. It follows that the household is the model of right order in the commonwealth. And just as the whole body enjoys health when every particular member performs its proper function, so all will be well with the commonwealth when families are properly regulated.

We have said that a commonwealth is the rightly ordered government of a number of families and of those matters which are their common concern, by a sovereign power. The phrase a number cannot mean just two, for the law requires at least three persons to constitute a college, and the same number to constitute a family in addition to its head, whether they be his children, slaves, freedmen, or free dependants who have voluntarily submitted to his authority. He is the fourth member of the group. Furthermore, since households, colleges and corporate bodies of all sorts, commonwealths, and indeed the whole human race would perish unless perpetuated from generation to generation, no family is complete without the wife, who is therefore called the mother of the family. By this reckoning, a minimum of five persons is required to constitute a family. I think this is the reason why ancient writers, such as Apuleius, said that fifteen persons could become a political community, meaning by that three complete households. Otherwise, even if the head of the family had three hundred wives and six hundred children, like Hermotinus, King of Parthia, or five hundred slaves like Crassus, if all these persons were a single household under the authority of a single head, they would not constitute either a political community or a commonwealth, but only a family....

The law says that the people never dies, but that after the lapse of a hundred or even a thousand years it is still the same people. The presumption is that although all individuals alive at any one moment will be dead a century later, the people is immortal by succession of persons, as was Theseus' ship which lasted as long as pains were taken to repair it. But a ship is no more than a load of timber unless there is a keel to hold together the ribs, the prow, the poop and the tiller. Similarly a commonwealth without sovereign power to unite all its several members, whether families, colleges, or corporate bodies, is not a true commonwealth. It is neither the tow nor its inhabitants that makes a city state, but their union under a sovereign ruler, even if they are only three households. Just as the mouse is as much numbered among animals as is the elephant, so the rightly ordered government of only three households, provided they are 
subject to a sovereign authority, is just as much a commonwealth as a great empire. The principality of Ragusa, which is one of the smallest in Europe, is no less a commonwealth than the empires of the Turks and the Tartars, which are among the greatest in the world....

But besides sovereign power there must also be something enjoyed in common such as the public domain, a public treasury, the buildings used by the whole community, the roads, walls, squares, churches, and markets, as well as the usages, laws, customs, courts, penalties, and rewards which are either shared in common or of public concern. There is no commonwealth where there is no common interest... It is not desirable however that all things, including women and children, should be possessed in common as Plato advocated in his Republic. His intention was to banish from the city the words 'mine' and 'thine', since he thought them the cause of all the misfortunes and disasters that befall commonwealths. He forgot that even if this could be achieved, then the peculiar mark of a commonwealth would be lost. For nothing could properly be regarded as public if there were nothing at all to distinguish it from what was private. Nothing can be thought of as shared in common, except by contrast with what is privately owned. If all citizens were kings there would be no king. There can be no harmony if the subtle combination of various chords, which is the charm of harmony, is reduced to a monotone. Moreover such a commonwealth would be directly contrary to the law of God and of nature, for that law not only condemns the incests, adulteries, and parricides which would be the inevitable consequence of women being possessed in common, but forbids theft, or even the mere coveting of that which is the private possession of another. We see therefore that commonwealths were ordained of God to the end that men should render to the community that which is required in the public interest, and to each individual that which is proper to him....

It is of course possible for all the subjects of a commonwealth to live in common, as did the Cretans and the Spartans in ancient times... or as the Anabaptists attempted to do when they founded their community in the city of Münster. They ruled that all things should be possessed in common save only women and personal belongings, thinking this would promote amity and mutual concord. They soon discovered their mistake however. So far from accomplishing what they expected, and banishing quarrels and animosities, they destroyed affection between husband and wife, and the love of parents 
for their children, the reverence of children for their parents, and the goodwill of parents towards one another.[1] Such are the consequences of ignoring the tie of blood, the strongest bond there is. It is common knowledge that no one feels any very strong affection for that which is common to all. Common possession brings in its train all sorts of quarrels and antagonisms. They deceive themselves who think that persons and property possessed in common will be much cared for, for it may be observed everywhere, that those things which are public property are habitually neglected, unless someone calculates that he may extract some private advantage from looking after them. The proper organization of the household requires the separation and distinction of the goods, the women, the children, and servants, of one family from another, and that which pertains to each from that which is common to all, or in other words pertains to the public good....

So much for the difference and the resemblance that there is between the family and the commonwealth in general. Let us now consider the members of the family. The government of all commonwealths, colleges, corporate bodies, or households whatsoever, rests on the right to command on one side, and the obligation to obey on the other, which arises when the natural liberty which each man has to live as he chooses, is exercised subject to the power of another. The right to command another is either of a public or a private character; public when vested in a sovereign who declares the law, or in the magistrate who executes it, and issues orders binding on his subordinates and private citizens generally; private when vested in heads of households, or in the collective authority which colleges and corporate bodies exercise over their particular members, or the minority of the whole body. Authority in the family rests on the fourfold relationship between husband and wife, father and child, master and servant, owner and slave. And since the rightful government of any society, public or private, depends on a proper understanding of how to command and how to obey, we will consider the household in the order described.

We understand by natural liberty the right under God to be subject to no man living and amenable only to those commands which are self-imposed, that is to say the commands of right reason conformable to the will of God. The first of all commandments was the commandment to subordinate animal appetite to reason, for before a man can govern others he must learn to govern 
himself, surrendering to reason the power of direction, and schooling the appetites to obedience. In this way each man will achieve that which truly pertains to his nature, which is the original and purest form of justice. The Hebrews expressed this proverbially in their saying 'Charity begins at home', meaning that one should subordinate appetite to reason in accordance with the first express commandment of God, laid upon him who killed his brother. The commandment that He had given the husband to rule over his wife has a double significance, first in the literal sense of marital authority, and second in the moral sense of the soul over the body, and the reason over concupiscence, which the Scriptures always identify with the woman. ...

From the moment a marriage is consummated the woman is subject to her husband, unless he is still living as a dependant in his father's house. Neither slaves nor other dependants have any authority over their wives, still less over their children. They are all subject to the head of the family until such time as he shall have given his married son his independence. No household can have more than one head, one master, one seigneur. If there were more than one head there would be a conflict of command and incessant family disturbances... wherefore a woman marrying a man still living in his father's house is subject to her father-in-law. ...

By a law of Romulus the husband was not only given full authority over his wife but could without any formal process of law take her life on four occasions, when she was taken in adultery, for substituting a child not his own, for having duplicate keys, or for being habitually drunk ... In order to show how general among all people has been this subjection of women, I will add two or three examples. We read that by the laws of the Lombards wives were held in the same subjection as had been customary among the ancient Romans, and their husbands had a power of life and death over them that they were still exercising when Baldus was writing, only two hundred and sixty years ago. As for our ancestors, the Gauls, nowhere in the world have husbands enjoyed a more absolute power than among them. Caesar makes this clear in his Memoirs when he says that they had the same absolute power of life and death over their wives and children as over their slaves....

With regard to divorce, the law of God permitted the husband to repudiate his wife, if she did not please him, on condition that he never took her back, but married another. This was at one time a custom common to all 
peoples, and is still practised in Africa and throughout the East. It was a means of humbling proud wives, while the knowledge that he had repudiated one wife without sufficient provocation made it difficult for an exacting husband to find another. If it is objected that it does not seem right that a man should be able to repudiate his wife without giving any reason, I appeal to the common usage in the matter. There is nothing more ill-advised than to compel two people to go on living together unless they are willing to publish the reason for the separation that they desire. The honour of both parties is at stake, whereas it is safeguarded if no reason has to be alleged....

However great the variety, and subsequent changes in law, it has never been customary anywhere to exempt wives from the obedience, and even the reverence which they owe their husbands ... Therefore in all systems of law the husband is regarded as the master of his wife's actions, and entitled to the usufruct of any property she may have, while the wife cannot come into the courts either as plaintiff or defendant save with the consent of her husband, or should he withhold it, the permission of the magistrate. The power, authority, and command that a husband has over his wife is allowed by both divine and positive law to be honourable and right. I know that in marriage alliances and settlements clauses are sometimes included exempting the wife from subjection to her husband. But such stipulations cannot detract from the authority of the husband, for they are contrary to both divine and positive law, as well as to the public interest. They are therefore invalid, and oaths to observe them cannot in consequence bind the husband.

The rightly ordered government of a father over his children lies first in the proper exercise of that power which God gives to a father over his natural children, and the law over his adopted ones, and second in the obedience, love, and reverence that children owe their father. Authority properly belongs to all those who have recognized power to command another. So, says Seneca, the prince commands his subjects, the magistrate the citizens, the master his pupils, the captain his soldiers, and the lord his slaves. But of all these there is none that has a natural right to command save only the father, who is the image of Almighty God, the Father of all things. Therefore Plato, having first defined the laws which touch the honour of God, speaks of them as an introduction to the reverence that a son 
owes his father, from whom, after God, he draws his life and all he may expect to enjoy in this world. And just as nature impels the father to foster his child so long as he is defenceless, and educate him in honourable and virtuous principles, so the child is prompted, and by an even stronger impulse, to love, honour, serve, and care for his father, to be obedient to his commands, support him, protect him, conceal all his infirmities and imperfections, and to spare neither goods nor life to preserve the life of him from whom he draws his own. This obligation is obvious, and founded in nature. But if one wishes further proof, one has only to remember that it was the first commandment in the second table of the law, and the only one of the ten commandments of the Decalogue that carried with it any promise of reward, for it is not usual to reward one who simply does that which he is under a strict obligation to do by both divine and positive law. Conversely we find the first curse recorded in Scripture was the curse laid on Ham for not concealing his father's shame....

In any rightly ordered commonwealth, that power of life and death over their children which belongs to them under the law of God and of nature, should be restored to parents. This most primitive of customs was observed in ancient times by the Persians, and people of Asia generally, by the Romans and the Celts; it was also recognized throughout the New World till the time of the Spanish conquests. If this power is not restored, there is no hope of any restoration of good morals, honour, virtue, or the ancient splendour of commonwealths. Justinian and those who have repeated him are wrong in saying that the Romans alone recognized such power of parents over their children. We have the testimony of the law of God which ought to be regarded as holy and inviolate by all peoples. We also have the evidence of Greek and Roman historians such as Caesar, of the customs of the Persians, the Romans, and the Celts. He said of the Gauls that they had power of life and death as much over their wives and children as over their slaves.

Moreover by the laws of Romulus, whereas the power of life and death which a husband had over his wife was restricted to four occasions only, that which he had over his children was unqualified, being a plenary power to dispense life or death to them as he thought fit, and to be seized of all property which they might acquire. Roman fathers had such authority not only over their natural children, but also over their children by adoption. ...

A father is bound to educate and instruct his children, especially in the 
fear of God. But if he fails of his duty, the son is not excused his, though Solon in his laws acquitted children from the obligation of supporting their father if he had failed to apprentice them to some trade by which they could earn a living. There is no need to enter into any discussion of this particular point since we are only concerned here with the question of paternal authority. One of the greatest benefits which resulted from it in ancient times was the proper upbringing of children. Public courts do not take cognizance of the contempt, disobedience, and irreverence of children towards their parents, nor the vices to which their indiscipline disposes the young, such vices as extravagance, drunkenness, fornication, and gambling, not to mention those graver crimes punishable by law, which their unhappy parents neither dare to discover, nor have the power to punish. For children who stand in little awe of their parents, and have even less fear of the wrath of God, readily set at defiance the authority of magistrates, who in any case are chiefly occupied with the habitual criminal. It is therefore impossible that a commonwealth should prosper while the families which are its foundation are ill-regulated. ...

Yet paternal power was gradually undermined in the time of the decline of the Roman Empire. The antique virtue thereupon vanished and with it the glory of the Republic, and a million vices and evil habits replaced the old loyalty and upright ways. For the paternal power of life and death was gradually restricted by the ambition of the magistrates, who wished to extend their own jurisdiction over all such matters ... Nowadays, fathers having been deprived of their paternal authority, and any claim to property acquired by their children, it is even suggested that the son can defend himself and resist by force any unjust attempt at coercion on the part of his father, and there are those that agree that he can ... But I hold that it is imperative that princes and legislators should revive the ancient laws touching the power of fathers over their children, and restore the usages prescribed by the law of God....

It may be objected that an enraged father may abuse the power which he has over the life and property of his children. The law however puts those who are truly mad under ward, and takes from them any power over others when they do not possess it over themselves. But if a father is not out of his mind, he will never be tempted to kill his own child without cause, and if the son has merited such a fate, it is not for the magistrate to intervene. 
The affection of parents for their children is so strong, that the law has always rightly presumed that they will only do those things which are of benefit and honour to their children. The real danger lies in the temptation of parents to be too partial. Indeed there are innumerable cases of parents setting at defiance both divine and positive law in order to advance the interests of their children by fair means or foul. Therefore the father who kills his son is not liable to the same penalty as the parricide, for the law presumes he would only commit such an act upon good and just grounds. The law moreover gives him, to the exclusion of all others, the right to kill the adulteress, or his daughter taken in sin. All these instances show that parents are not suspected of being liable to abuse their authority. Even if it be true that there have been cases where such powers have been misused, one cannot refuse to establish a good custom because certain ill consequences might occasionally ensue. No law, however just, natural, and necessary, but carries with it some risks. Anyone who wished to abolish all those laws which were liable to give rise to difficulties would abolish all laws whatsoever. But I hold that the natural affection of parents for their children is incompatible with cruelty and abuse of power....

The third type of government in the household is that of the lord over his slaves and the master over his servants ... And seeing that there are slaves all over the world except in that quarter which is Europe, we must necessarily consider the power of masters over their slaves, and the advantages and disadvantages of the institution. It is a matter of moment both to families and to commonwealths everywhere.

Slaves are either naturally so, being born of slave women, or slaves by right of conquest, or in punishment for some crime, or because they have sold or gambled away their liberty to another ... Household servants are in no sense slaves but free men, and both before the law, and in fact, have an equal liberty of action. All the same they are not simply paid employees or day labourers over whom those who have hired their services have no such authority or right of punishment as the master has over his servants. For so long as they are members of their master's household they owe him service, respect, and obedience, and he can correct and punish them, though with discretion and moderation. Such briefly is the power of masters over their servants, for we do not want here to enter into any discussion of the rules which should govern the conduct proper on each side. 
But the institution of slavery raises difficulties which have never been satisfactorily resolved. First of all, is slavery natural and useful, or contrary to nature? And second, what power should the master have over the slave? Aristotle was of opinion that servitude was natural, and alleged as proof that it is obvious that some are born fit only to serve and obey, others to govern and command. On the other hand jurists, who are less concerned with philosophical arguments than with commonly received opinions, hold that servitude is directly contrary to nature, and have always done what they could to defend personal liberty, despite the obscurity of laws, testaments, legal decisions, and contracts....

Let us consider which of these two opinions is the better founded. There is a certain plausibility in the argument that slavery is natural and useful to the commonwealth. That which is contrary to nature cannot endure, and despite any force and violence that one can use, the natural order will always re-establish itself, as is clear from the behaviour of all natural agents. Slavery appeared suddenly in the world after the flood, and at the very same time that the first commonwealths began to take shape, and has persisted from that day to this. Although in the last three or four hundred years it has been abolished in many places, one continually sees it reappearing in some form. For instance in the West Indies, which are three times as extensive as the whole of Europe, people who have no knowledge of divine and positive laws to the contrary, have always had great numbers of slaves. There is not a commonwealth to be found anywhere that has never known the institution, and wise and good men in all ages have owned and employed slaves. What is more, in all commonwealths the master is always recognized as having absolute power to dispose of the lives and belongings of his slaves as he thinks fit, save in a few cases where princes and lawgivers have restricted this power. It cannot be that so many rulers and legislators have upheld an institution which was unnatural, or so many wise and virtuous men approved of them for doing so, or so many peoples for so many centuries maintained the practice of slavery, and even restricted the right of manumission, and still prospered in peace and war, if it had been against nature.

Again, who would deny that it is laudible and charitable to spare the life of a prisoner taken in legitimate warfare who cannot find a ransom, instead of killing him in cold blood, for this was generally the origin of 
enslavement. Moreover a man is required by divine and positive law to submit to corporal punishment if he cannot pay the forfeit for any act he has committed. No one doubts that those who make violent assaults upon the goods and lives of others are brigands and robbers, deserving of death. It cannot be against nature in such a case to exact services from the malefactor instead of killing him. If it were against nature to have power of life and death over another, all kingdoms and lordships in the world would be against nature, seeing that kings and princes have the like power over their subjects, noble and simple, if they are proved guilty of a capital crime.

All these arguments tend to prove that slavery is natural, useful, and right. I think however that strong objections can be urged against them all. I agree that servitude is natural where the strong, brutal, rich, and ignorant obey the wise, prudent, and humble, poor though they may be. But no one would deny that to subject wise men to fools, the well-informed to the ignorant, saints to sinners is against nature ... One sees in fact how often quiet and peaceable men are the prey of evildoers. When princes attempt to settle their differences by war, it is always claimed that the victor had right on his side, and the vanquished were in the wrong. If the vanquished did indeed make war without just cause, as do brigands, ought one not rather to make an example of them and put them to death, than to show them mercy? As for the argument that slavery could not have been so enduring if it had been contrary to nature, I would answer that the principle holds good for natural agents whose property it is to obey of necessity the unchanging laws of God. But man, being given the choice between good and evil, inclines for the most part to that which is forbidden, and chooses the evil, defying the laws of God and of nature. So much is such a one under the domination of his corrupt imagination, that he takes his own will for the law. There is no sort of impiety or wickedness which in this way has not come to be accounted virtuous and good. I will be content with one instance. It is sufficiently obvious that there can be no more cruel and detestable practice than human sacrifice. Yet there is hardly a people which has not practised it, and each and all have done so for centuries under the cover of piety. In our own times it was common throughout the Western Isles... Such things show how little the laws of nature can be deduced from the practices of men, however inveterate, and one cannot on these grounds accept slavery as natural. Again, what charity is there in sparing captives in order to derive some profit or advantage from them as if they were cattle? For where is the man 
who would spare the lives of the vanquished if he saw more profit in killing than in sparing them? ...

I will refrain from setting down in words the base humiliations that slaves have been made to suffer. But the cruelties one reads about are unbelievable, and yet only the thousandth part has been told. For writers only refer to the subject incidentally, and such accounts as we have, come from the most civilized races in the world. Slaves were made to work in the fields chained, as they still do in Barbary, and sleep in the open when work was done, as they still do everywhere in the East, for fear that they would abscond, or fire the house, or murder their masters ... So much have cities and commonwealths always feared their slaves that they have never dared to permit them the use of arms, or to be enrolled for service. It was forbidden on pain of death... Yet they never succeeded so well but that some desperate man, by promising liberty to the slaves, threw the whole state into confusion, as did Viriat the pirate who made himself King of Portugal, Cinna, Spartacus, and others down to Simon Gerson the Jew. All these raised themselves from humble origins to be powerful rulers simply by enfranchising the slaves who joined them....

Since the Christian religion was established however the number of slaves has diminished. The process was hastened by the publication of the law of Mahomet, which enfranchised all who professed that faith. By the year 1200 slavery had been abolished nearly everywhere save in the West Indies, where great numbers were found at the time of their discovery... It may be objected that if the Mohammedans really enfranchised their co-religionists, who cover the whole of Asia, the greater part of Africa and even a considerable area of Europe, and the Christians have done the same, how come there to be still so many slaves in the world? For the Jews by the terms of their law may not make slaves of their own people either, nor yet of Christians if they live in a Christian country, still less of Mohammedans among whom they are chiefly settled. The answer is that those who profess all these three religions only partially observe the law of God with regard to slaves, for by the law of God it is forbidden to make any man a slave except with his own entire good will and consent... Seeing that the experience of four thousand years has shown us the insurrections, the civil commotions, the disasters and revolutions that commonwealths have suffered at the hands of slaves, and the homicides, the cruelties and barbarities 
inflicted on slaves by their masters, it was an unmitigated catastrophe that the institution was ever introduced, and then, that once it had been declared abolished, it should ever have been allowed to persist.

\section{Concerning the Citizen [CHAPTERS VI AND VII]}

...WHEN the head of the family leaves the household over which he presides and joins with other heads of families in order to treat of those things which are of common interest, he ceases to be a lord and master, and becomes an equal and associate with the rest. He sets aside his private concerns to attend to public affairs. In so doing he ceases to be a master and becomes a citizen, and a citizen may be denned as a free subject dependent on the authority of another.

Before such things as cities and citizens, or any form of commonwealth whatsoever, were known among men, each head of a family was sovereign in his household, having power of life and death over his wife and children. But force, violence, ambition, avarice, and the passion for vengeance, armed men against one another. The result of the ensuing conflicts was to give victory to some, and to reduce the rest to slavery. Moreover the man who had been chosen captain and leader by the victors, under whose command success had been won, retained authority over his followers, who became his loyal and faithful adherents, and imposed it on the others, who became his slaves. Thus was lost the full and entire liberty of each man to live according to his own free will, without subjection to anyone. It was completely lost to the vanquished and converted into unmitigated servitude; it was qualified in the case of the victors in that they now rendered obedience to a sovereign leader. Anyone who did not wish to abandon part of his liberty, and live under the laws and commands of another, lost it altogether. Thus the words, hitherto unknown, of master and servant, ruler and subject, came into use.

Reason and common sense alike point to the conclusion that the origin and foundation of commonwealths was in force and violence. If this is not enough, it can be shown on the testimony of such historians as Thucydides, Plutarch, Caesar, and even by the laws of Solon, that the first generations of men were unacquainted with the sentiments of honour, and their highest endeavour was to kill, torture, rob, and enslave their fellows. So says Plutarch. We also have the evidence of sacred history, where it is said 
that Nimrod, the youngest son of Ham, was the first to subject his followers by force and violence. Wherefore he was called the mighty hunter, which to the Hebrews suggests the robber and despoiler. Demosthenes, Aristotle, and Cicero laboured under a misapprehension in repeating the error of Herodotus, who held that the first kings were chosen for their justice and their virtue, in what were believed to be heroic times. I have rebutted this view elsewhere[2] on the grounds that in the first commonwealths, and for a long time after Abraham, there were innumerable slaves, as indeed was also found to be the case in the West Indies. This could hardly be unless there had been some violent forcing of the laws of nature....

Such being the origin of commonwealths, it is clear why a citizen is to be defined as a free subject who is dependent on the sovereignty of another. I use the term free subject, because although a slave is as much, or more, subject to the commonwealth as is his lord, it has always been a matter of common agreement that the slave is not a citizen, and in law has no personality. This is not the case with women and children, who are free of any servile dependence, though their rights and liberties, especially their power of disposing of property, is limited by the domestic authority of the head of the household. We can say then that every citizen is a subject since his liberty is limited by the sovereign power to which he owes obedience. We cannot say that every subject is a citizen. This is clear from the case of slaves. The same applies to aliens. Being subject to the authority of another, they have no part in the rights and privileges of the community....

Just as slaves can be slaves either by birth or by convention, so citizens can be either natural or naturalized. The natural citizen is the free subject who is a native of the commonwealth, in that both, or one or other of his parents, was born there... The naturalized citizen is one who makes a voluntary submission to the sovereign authority of another, and is accepted by him as Us subject. An honorary citizen who has been granted certain privileges such as civic rights, either as the reward of merit, or an act of grace and favour, is not properly a citizen because he does not thereby become a subject. The whole body of the citizens, whether citizens by birth, by adoption or by enfranchisement (for these are the three ways in which citizen rights are acquired) when subjected to the single sovereign power of one or more rulers, constitutes a commonwealth, even if there is diversity 
of laws, language, customs, religion, and race. If all the citizens are subject to a single uniform system of laws and customs they form not only a commonwealth but a commune,[3] even though they be dispersed in divers townships, villages, or the open countryside. The town is not the commune, as some have held, any more than the house is the household, for dependants and children can live in widely separated places, yet still form a household, if they are subject to a single head of the family. The same applies to the commune. It can consist of a number of townships and villages, provided they share the same customs, as is the case with the bailliwicks of this realm. Similarly the commonwealth can include a number of communes and provinces which all have different customs. But so long as they are subject to the authority of a single sovereign, and the laws and ordinances made by it, they constitute a commonwealth. ...

It is a very grave error to suppose that no one is a citizen unless he is eligible for public office, and has a voice in the popular estates, either in a judicial or deliberative capacity. This is Aristotle's view. Later he corrects himself when he observes that it only applies to popular states. But he himself said in another place that a definition is valueless unless it is of universal application ... Plutarch improved on this description when he said that citizenship implied a right to a share in the rights and privileges of a city-state, implying that he meant such a share as accorded with the standing of each, nobles, commoners, women, and children too, according to the differences of age, sex, and condition ... It must however be emphasized that it is not the rights and privileges which he enjoys which makes a man a citizen, but the mutual obligation between subject and sovereign, by which, in return for the faith and obedience rendered to him, the sovereign must do justice and give counsel, assistance, encouragement, and protection to the subject. He does not owe this to aliens... Moreover, although a man can be a slave of more than one master, or a vassal of more than one lord provided they all hold of the same overlord, a citizen cannot be the subject of more than one sovereign, unless they are both members of a federated state. For princes are not subject to any jurisdiction which delimits their claims over their subjects, as are lords and masters in respect of their vassals and slaves. Neglect of this principle is the reason why there are so frequently frontier wars between neighbouring princes. Each claims the population of the march country as his own. These latter recognize one or other disputant as it suits them, or escape dependence on 
either, and in consequence are invaded and pillaged by both sides equally. $\cdots$

It is a generally accepted principle of public right that mere change of domicile from one country to another does not deprive the subject of his citizen rights, nor his prince of his sovereign authority over him. The case is parallel to that of the vassal who under feudal custom cannot escape the faith he owes his lord, any more than his lord can excuse himself from the obligation to protect his vassal, unless there has been agreement between them to this effect, seeing that the obligation is mutual and reciprocal. But if both parties have expressly or tacitly consented, and the prince has suffered his subject to renounce his subjection and submit to another, then the subject is no longer bound in obedience to his former sovereign ... In order then to acquire full rights of citizenship, it is not sufficient to have been domiciled for the statutary period. Letters of naturalization must also have been asked for and obtained. A settlement cannot be made on anyone unless the benefactor has offered, and the beneficiary duly accepted, the gift offered. Similarly an alien does not become a citizen, nor the subject of a foreign prince, until he has been received as such by that prince, but remains the subject of his natural prince. The same is the case if he has asked for admission to citizenship and been refused. ...

It is therefore the submission and obedience of a free subject to his prince, and the tuition, protection, and jurisdiction exercised by the prince over his subject that makes the citizen. This is the essential distinction between the citizen and the foreigner. All other differences are accidental and circumstantial, though it is an almost universal rule in commonwealths that all or certain offices and benefices should be open only to citizens, and aliens debarred from them altogether. ...

As for the differences that distinguish different classes of subjects from each other, they are almost as numerous as those which distinguish citizens from aliens, taking all places into account. I have referred to some, the difference between noble and commoner, adults and children, men and women. There are also distinctions of persons before the law, some being exempt from the taxes, charges, and impositions that others are subject to. In nearly every state in Europe citizens are divided into the three orders of 
nobles, clergy, and people. In addition to this general division there are special arrangements in certain commonwealths such as the division into gentlemen, citizens, and proletariat in Venice ... Even Plato, although he intended all his citizens to enjoy an equality of rights and privileges, divided them into the three orders of guardians, soldiers, and labourers. All this goes to show that there never was a commonwealth, real or imaginary, even if conceived in the most popular terms, where citizens were in truth equal in all rights and privileges. Some always have more, some less than the rest.

So much for the meaning of the terms subject, citizen, and alien. Let us now consider allies, especially those under protection, for no one who has written about the commonwealth has considered this subject, important as it is for all governments. The term protection can be applied in a general sense to all subjects owing obedience to a sovereign lord or prince. As we have already shown, the prince is obliged to safeguard the persons, possessions, and families of his subjects, by force of arms, and by force of law, while his subjects are under a reciprocal obligation to give their prince loyal and obedient service. This is the first and most effective form of protection there is. The rights of protection that masters have over their slaves, patrons over their freedmen, and lords over their vassals are much inferior. The slave, freedman, vassal, it is true, owes faith, homage, and service to his lord, but subject to the prior claims of his sovereign prince, whose liege man he is. In the same way the soldier owes obedience and assistance to his captain, and merits death if he does not guard his life at the risk of his own.

But in treaties between sovereign princes the word protection is used in a special sense, implying neither subjection on the part of the one who is protected, nor right to command in the one who protects. The latter can only claim honour and reverence from those whose defence he has undertaken; their sovereignty is in no way diminished by the relationship, nor has he any authority over them. This particular right of protection is therefore the best, the most honourable and dignified of all rights. Sovereign princes, masters, patrons, and overlords exact obedience and derive some profit from the defence of their subjects, slaves, freedmen, or vassals as the case may be. But the simple protector is satisfied with the mere honour and gratitude of his protégés. If he takes any profit it is not, properly 
speaking, simple protection that he gives. If anyone lends any of his belongings to another, or assists him by good offices on his behalf, but sees he makes a profit in so doing, he is no better than a mercenary who hires out his services for gain. In the same way if anyone freely promises assistance to another, he is obliged to redeem his promise without expecting any reward for so doing. There is no promise more binding than the undertaking to defend the goods, the life, and the honour of the weak against the strong, the poor against the rich, or the innocent threatened by the violence of wicked men. ...

Protégés are sometimes called clients, and protectors patrons, because of a similarity in the two relationships. But it is the difference between them that is more important. The freedman owes services to his patron and can be reduced to servitude again if he fails in his obligations. But the protégé owes no services, and cannot be deprived of his liberty however ingrate he may be. The freedman must leave a proportion of his goods to his patron should he predecease him. The protégé owes nothing of his inheritance to his protector. Again the vassal also resembles the protégé to such an extent that some have confused the two. But again, the difference between them is more significant than the resemblance. The vassal owes faith, homage, and honour to his lord. If he commits a felony, renounces his allegiance, or refuses the services due to his lord he loses his fief, which then reverts to his lord by right of escheat. The protégé, holding no fief, has no such penalty to fear. Furthermore if the vassal is his lord's liege man, he is also his natural subject, and owes him not only faith and homage but submission and obedience, and cannot escape from the authority of his sovereign lord without his consent, even should he have been deprived of his fief. The protégé bears no such relationship to his protector, and is not subject to him....

But in the case of the sovereign prince who puts himself under the protection of another, does he lose his sovereign authority thereby and become a subject? It would seem that if he recognizes a greater than himself, he is no longer sovereign. Nevertheless I hold that he does remain a sovereign, and in no sense becomes a subject. The point is settled by a passage in the civil law which is unique. There are various readings of it, but I follow the original of the Pandects at Florence, where it is said that in treaties of alliance between sovereign princes, those that put themselves 
under the protection of one greater than themselves do not become his subjects. Even when, in treaties of an unequal alliance, it is expressly stated that one of the parties will defend the authority of the other, this does not make the latter the subject of the former. Our protégés and clients are as free as we are ourselves, even though they may not be our equals in wealth, in power, or in honour...

Here someone may ask why allies bound together by an offensive and defensive alliance against all outsiders without exception, who share the same laws, customs, estates, and diets, should treat one another as foreigners. We have the example of the Swiss who have been leagued together in this way ever since 1315. I hold that such an alliance does not prevent its members remaining foreigners to one another, nor make them citizens of one another's countries... Many have made the mistake of thinking that the Swiss are members of a single commonwealth ... The Confederates and their allies altog ether consist of twenty-one republics in all, besides the Abbot of St. Gall who is a prince-bishop. Each Confederate state is a sovereign power with its own distinct magistrates, distinct estates, distinct revenues, distinct domain, distinct territory. The army, the emblem, the name, the coinage, the seal, the jurisdiction, the ordinances of each are separate from those of all the rest. If one of the cantons makes any conquest, the others have no share in it... The fact that there are common estates, a common domain, and general diets, and the fact that they acknowledge the same friends and enemies does not make them one state, even though they have a common treasury derived from certain taxes, for they do not recognize any sovereign power of making law for each and all of their subjects. In like case if a number of heads of families joined together to administer all their property in common, they would not make a single family. We regard the alliances made by the Romans with the other cities of Italy in the same way. They formed an offensive and defensive league against all without exception. Nevertheless they all remained distinct and sovereign states....

\section{Concerning Sovereignty [CHAPTER VIII]}

SOVEREIGNTY is that absolute and perpetual power vested in a commonwealth which in Latin is termed majestas ... The term needs careful definition, because although it is the distinguishing mark of a commonwealth, and an understanding of its nature fundamental to any treatment of politics, no 
jurist or political philosopher has in fact attempted to define it. ...

I have described it as perpetual because one can give absolute power to a person or group of persons for a period of time, but that time expired they become subjects once more. Therefore even while they enjoy power, they cannot properly be regarded as sovereign rulers, but only as the lieutenants and agents of the sovereign ruler, till the moment comes when it pleases the prince or the people to revoke the gift. The true sovereign remains always seized of his power. Just as a feudal lord who grants lands to another retains his eminent domain over them, so the ruler who delegates authority to judge and command, whether it be for a short period, or during pleasure, remains seized of those rights of jurisdiction actually exercised by another in the form of a revocable grant, or precarious tenancy. For this reason the law requires the governor of a province, or the prince's lieutenant, to make a formal surrender of the authority committed to him, at the expiration of his term of office. In this respect there is no difference between the highest officer of state and his humblest subordinate. If it were otherwise, and the absolute authority delegated by the prince to a lieutenant was regarded as itself sovereign power, the latter could use it against his prince who would thereby forfeit his eminence, and the subject could command his lord, the servant his master. This is a manifest absurdity, considering that the sovereign is always excepted personally, as a matter of right, in all delegations of authority, how ever extensive. However much he gives there always remains a reserve of right in his own person, whereby he may command, or intervene by way of prevention, confirmation, evocation, or any other way he thinks fit, in all matters delegated to a subject, whether in virtue of an office or a commission. Any authority exercised in virtue of an office or a commission can be revoked, or made tenable for as long or short a period as the sovereign wills.

These principles accepted as the foundations of sovereignty, it follows that neither the Roman Dictator, the Harmost of Sparta, the Esymnete of Salonika, the Archus of Malta, nor the ancient Balia of Florence (who had the same sort of authority), nor regents of kingdoms, nor holders of any other sort of commission, nor magistrates whatsoever, who have absolute power to govern the commonwealth for a certain term only, are possessed of sovereign authority. ... 
But supposing the king grants absolute power to a lieutenant for the term of his life, is not that a perpetual sovereign power? For if one confines perpetual to that which has no termination whatever, then sovereignty cannot subsist save in aristocracies and popular states, which never die. If one is to include monarchy too, sovereignty must be vested not in the king alone, but in the king and the heirs of his body, which supposes a strictly hereditary monarchy. In that case there can be very few sovereign kings, since there are only a very few strictly hereditary monarchies. Those especially who come to the throne by election could not be included.

A perpetual authority therefore must be understood to mean one that lasts for the lifetime of him who exercises it. If a sovereign magistrate is given office for one year, or for any other predetermined period, and continues to exercise the authority bestowed on him after the conclusion of his term, he does so either by consent or by force and violence. If he does so by force, it is manifest tyranny. The tyrant is a true sovereign for all that. The robber's possession by violence is true and natural possession although contrary to the law, for those who were formerly in possession have been disseized. But if the magistrate continues in office by consent, he is not a sovereign prince, seeing that he only exercises power on sufferance. Still less is he a sovereign if the term of his office is not fixed, for in that case he has no more than a precarious commission. ...

What bearing have these considerations on the case of the man to whom the people has given absolute power for the term of his natural life? One must distinguish. If such absolute power is given him simply and unconditionally, and not in virtue of some office or commission, nor in the form of a revocable grant, the recipient certainly is, and should be acknowledged to be, a sovereign. The people has renounced and alienated its sovereign power in order to invest him with it and put him in possession, and it thereby transfers to him all its powers, authority, and sovereign rights, just as does the man who gives to another possessory and proprietary rights over what he formerly owned. The civil law expresses this in the phrase 'all power is conveyed to him and vested in him'.[4]

But if the people give such power for the term of his natural life to anyone as its official or lieutenant, or only gives the exercise of such power, in such a case he is not a sovereign, but simply an officer, 
lieutenant, regent, governor, or agent, and as such has the exercise only of a power inhering in another. When a magistrate institutes a perpetual lieutenant, even if he abandons all his rights of jurisdiction and leaves their exercise entirely to his lieutenant, the authority to command and to judge nevertheless does not reside in the lieutenant, nor the action and force of the law derive from him. If he exceeds his authority his acts have no validity, unless approved and confirmed by him from whom he draws his authority. For this reason King John, after his return from captivity in England, solemnly ratified all the acts of his son Charles, who had acted in his name as regent, in order, as was necessary, to regularize the position.

Whether then one exercises the power of another by commission, by institution, or by delegation, or whether such exercise is for a set term, or in perpetuity, such a power is not a sovereign power, even if there is no mention of such words as representative, lieutenant, governor, or regent, in the letters of appointment, or even if such powers are a consequence of the normal working of the laws of the country. In ancient times in Scotland, for instance, the law vested the entire governance of the realm in the next of kin, if the king should be a minor, on condition that everything that was done, was done in the king's name. But this law was later altered because of its inconvenient consequences.

Let us now turn to the other term of our definition and consider the force of the word absolute. The people or the magnates of a commonwealth can bestow simply and unconditionally upon someone of their choice a sovereign and perpetual power to dispose of their property and persons, to govern the state as he thinks fit, and to order the succession, in the same way that any proprietor, out of his liberality, can freely and unconditionally make a gift of his property to another. Such a form of gift, not being qualified in any way, is the only true gift, being at once unconditional and irrevocable. Gifts burdened with obligations and hedged with conditions are not true gifts. Similarly sovereign power given to a prince charged with conditions is neither properly sovereign, nor absolute, unless the conditions of appointment are only such as are inherent in the laws of God and of nature.

If we insist however that absolute power means exemption from all law whatsoever, there is no prince in the world who can be regarded as 
sovereign, since all the princess of the earth are subject to the laws of God and of nature, and even to certain human laws common to all nations. On the other hand, it is possible for a subject who is neither a prince nor a ruler, to be exempted from all the laws, ordinances, and customs of the commonwealth. We have an example in Pompey the Great who was dispensed from the laws for five years, by express enactment of the Roman people, at the instance of the Tribune Gabinius ... But notwithstanding such exemptions from the operations of the law, the subject remains under the authority of him who exercises sovereign power, and owes him obedience.

On the other hand it is the distinguishing mark of the sovereign that he cannot in any way be subject to the commands of another, for it is he who makes law for the subject, abrogates law already made, and amends obsolete law. No one who is subject either to the law or to some other person can do this. That is why it is laid down in the civil law that the prince is above the law, for the word law in Latin implies the command of him who is invested with sovereign power. Therefore we find in all statutes the phrase 'notwithstanding all edicts and ordinances to the contrary that we have infringed, or do infringe by these present'. This clause applies both to former acts of the prince himself, and to those of his predecessors. For all laws, ordinances, letters patent, privileges, and grants whatsoever issued by the prince, have force only during his own lifetime, and must be expressly, or at least tacitly, confirmed by the reigning prince who has cognizance of them ... In proof of which, it is the custom of this realm for all corporations and corporate bodies to ask for the confirmation of their privileges, rights, and jurisdictions, on the accession of a new king. Even Parlements and high courts do this, as well as individual officers of the crown.

If the prince is not bound by the laws of his predecessors, still less can he be bound by his own laws. One may be subject to laws made by another, but it is impossible to bind oneself in any matter which is the subject of one's own free exercise of will. As the law says, 'there can be no obligation in any matter which proceeds from the free will of the undertaker'.[5] It follows of necessity that the king cannot be subject to his own laws. Just as, according to the canonists, the Pope can never tie his own hands, so the sovereign prince cannot bind himself, even if he wishes. For this reason edicts and ordinances conclude with the formula 'for such is our good 
pleasure', thus intimating that the laws of a sovereign prince, even when founded on truth and right reason, proceed simply from his own free will.

It is far otherwise with divine and natural laws. All the princes of the earth are subject to them, and cannot contravene them without treason and rebellion against God. His yoke is upon them, and they must bow their heads in fear and reverence before His divine majesty. The absolute power of princes and sovereign lords does not extend to the laws of God and of nature. He who best understood the meaning of absolute power, and made kings and emperors submit to his will, defined his sovereignty as a power to override positive law; he did not claim power to set aside divine and natural law.[6]

But supposing the prince should swear to keep the laws and customs of his country, is he not bound by that oath? One must distinguish. If a prince promises in his own heart to obey his own laws, he is nevertheless not bound to do so, any more than anyone is bound by an oath taken to himself. Even private citizens are not bound by private oaths to keep agreements. The law permits them to cancel them, even if the agreements are in themselves reasonable and good. But if one sovereign prince promises another sovereign prince to keep the agreements entered into by his predecessors, he is bound to do so even if not under oath, if that other prince's interests are involved. If they are not, he is not bound either by a promise, or even by an oath.

The same holds good of promises made by the sovereign to the subject, even if the promises were made prior to his election (for this does not make the difference that many suppose). It is not that the prince is bound either by his own laws or those of his predecessors. But he is bound by the just covenants and promises he has made, whether under oath to do so or not, to exactly the same extent that a private individual is bound in like case. A private individual can be released from a promise that was unjust or unreasonable, or beyond his competence to fulfil, or extracted from him by misrepresentations or fraud, or made in error, or under restraint and by intimidation, because of the injury the keeping of it does him. In the same way a sovereign prince can make good any invasion of his sovereign rights, and for the same reasons. So the principle stands, that the prince is not subject to his own laws, or those of his predecessors, but is bound by the 
just and reasonable engagements which touch the interests of his subjects individually or collectively.

Many have been led astray by confusing the laws of the prince with covenants entered into by him. This confusion has led some to call these covenants contractual laws. This is the term used in Aragon when the king issues an ordinance upon the petition of the Estates, and in return receives some aid or subsidy. It is claimed that he is strictly bound by these laws, even though he is not by any of his other enactments. It is however admitted that he may override even these when the purpose of their enactment no longer holds. All this is true enough, and well-founded in reason and authority. But no bribe or oath is required to bind a sovereign prince to keep a law which is in the interests of his subjects. The bare word of a prince should be as sacred as a divine pronouncement. It loses its force if he is ill-thought of as one who cannot be trusted except under oath, nor relied on to keep a promise unless paid to do so. Nevertheless it remains true in principle that the sovereign prince can set aside the laws which he has promised or sworn to observe, if they no longer satisfy the requirements of justice, and he may do this without the consent of his subjects. It should however be added that the abrogation must be express and explicit in its reference, and not just in the form of a general repudiation. But if on the other hand there is no just cause for breaking a law which the prince has promised to keep, the prince ought not to do so, and indeed cannot contravene it, though he is not bound to the same extent by the promises and covenants of his predecessors unless he succeeds by strict hereditary right.

A law and a covenant must therefore not be confused. A law proceeds from him who has sovereign power, and by it he binds the subject to obedience, but cannot bind himself. A covenant is a mutual undertaking between a prince and his subjects, equally binding on both parties, and neither can contravene it to the prejudice of the other, without his consent. The prince has no greater privilege than the subject in this matter. But in the case of laws, a prince is no longer bound by his promise to keep them when they cease to satisfy the claims of justice. Subjects however must keep their engagements to one another in all circumstances, unless the prince releases them from such obligations. Sovereign princes are not bound by oath to keep the laws of their predecessors. If they are so bound, they are not properly speaking 
sovereign. ...

The constitutional laws of the realm, especially those that concern the king's estate being, like the salic law, annexed and united to the Crown, cannot be infringed by the prince. Should he do so, his successor can always annul any act prejudicial to the traditional form of the monarchy,[7] since on this is founded and sustained his very claim to sovereign majesty....

As for laws relating to the subject, whether general or particular, which do not involve any question of the constitution, it has always been usual only to change them with the concurrence of the three estates, either assembled in the States-General of the whole of France, or in each bailiwick separately. Not that the king is bound to take their advice, or debarred from acting in a way quite contrary to what they wish, if his acts are based on justice and natural reason. At the same time the majesty of the prince is most fully manifested in the assembly of the three estates of the whole realm, humbly petitioning and supplicating him, without any power of commanding or determining, or any right to a deliberative voice. Only that which it pleases the prince to assent to or dissent from, to command or to forbid, has the force of law and is embodied in his edict or ordinance.

Those who have written books about the duties of magistrates and such like matters [8] are in error in maintaining that the authority of the Estates is superior to that of the prince. Such doctrines serve only to encourage subjects to resist their sovereign rulers. Besides, such views bear no relation to the facts, except when the king is in captivity, lunatic or a minor. If he were normally subject to the Estates, he would be neither a prince nor a sovereign, and the commonwealth would not be a kingdom or a monarchy, but a pure aristocracy where authority is shared equally between the members of the ruling class....

Although in the Parliaments of the kingdom of England, which meet every three years, all three orders use great freedom of speech, as is characteristic of northern peoples, they still must proceed by petitions and supplications ... Moreover Parliaments in England can only assemble, as in this kingdom and in Spain, under letters patent expressly summoning them in the king's name. This is sufficient proof that Parliaments have no independent power of considering, commanding or determining, seeing that 
they can neither assemble nor adjourn without express royal command ... It may be objected that no extraordinary taxes or subsidies can be imposed without the agreement and consent of Parliament. King Edward I agreed to this principle in the Great Charter, which is always appealed to by the people against the claims of the king. But I hold that in this matter no other king has any more right than has the King of England, since it is not within the competence of any prince in the world to levy taxes at will on his people, or seize the goods of another arbitrarily, as Philippe de Comines very wisely argued at the Estates at Tours, as we may read in his Memoirs.[9]

We must agree then that the sovereignty of the king is in no wise qualified or diminished by the existence of Estates. On the contrary his majesty appears more illustrious when formally recognized by his assembled subjects, even though in such assemblies princes, not wishing to fall out with their people, agree to many things which they would not have consented to, unless urged by the petitions, prayers, and just complaints of a people burdened by grievances unknown to the prince. After all, he depends for his information on the eyes and ears and reports of others.

From all this it is clear that the principal mark of sovereign majesty and absolute power is the right to impose laws generally on alt subjects regardless of their consent ... And if it is expedient that if he is to govern his state well, a sovereign prince must be above the law, it is even more expedient that the ruling class in an aristocracy should be so, and inevitable in a popular state. A monarch in a kingdom is set apart from his subjects, and the ruling class from the people in an aristocracy. There are therefore in each case two parties, those that rule on the one hand, and those that are ruled on the other. This is the cause of the disputes about sovereignty that arise in them, but cannot in a popular state ... There the people, rulers and ruled, form a single body and so cannot bind themselves by their own laws....

When edicts are ratified by Estates or Parlements, it is for the purpose of securing obedience to them, and not because otherwise a sovereign prince could not validly make law. As Theodosius said with reference to the consent of the Senate, 'it is not a matter of necessity but of expediency'. He also remarked that it was most becoming in a sovereign prince to keep his own 
laws, for this is what makes him feared and respected by his subjects, whereas nothing so undermines his authority as contempt for them. As a Roman Senator observed 'it is more foolish and ill-judged to break your own laws than those of another'.

But may it not be objected that if the prince forbids a sin, such as homicide, on pain of death, he is in this case bound to keep his own law The answer is that this is not properly the prince's own law, but a law of God and nature, to which he is more strictly bound than any of his subjects. Neither his council, nor the whole body of the people, can exempt him from his perpetual responsibility before the judgement-seat of God, as Solomon said in unequivocal terms. Marcus Aurelius also observed that the magistrate is the judge of persons, the prince of the magistrates, and God of the prince. Such was the opinion of the two wisest rulers the world has ever known. Those who say without qualification that the prince is bound neither by any law whatsoever, nor by his own express engagements, insult the majesty of God, unless they intend to except the laws of God and of nature, and all just covenants and solemn agreements. Even Dionysius, tyrant of Syracuse, said to his mother that he could exempt her from the laws and customs of Syracuse, but not from the laws of God and of nature. For just as contracts and deeds of gift of private individuals must not derogate from the ordinances of the magistrate, nor his ordinances from the law of the land, nor the law of the land from the enactments of a sovereign prince, so the laws of a sovereign prince cannot override or modify the laws of God and of nature....

There is one other point. If the prince is bound by the laws of nature, and the civil law is reasonable and equitable, it would seem to follow that the prince is also bound by the civil law. As Pacatius said to the Emperor Theodosius 'as much is permitted to you as is permitted by the laws'. In answer to this I would point out that the laws of a sovereign prince concern either public or private interests or both together. All laws moreover can be either profitable at the expense of honour, or profitable without involving honour at all, or honourable without profit, or neither honourable nor profitable. When I say 'honour' I mean that which conforms with what is natural and right, and it has already been shown that the prince is bound in such cases. Laws of this kind, though published by the prince's authority, are properly natural laws. Laws which are profitable as well as just are 
even more binding on him. One need hardly concern oneself about the sanctity of laws which involve neither profit nor honour. But if it is a question of weighing honour against profit, honour should always be preferred. Aristides the Just said of Themistocles that his advice was always very useful to the people, but shameful and dishonourable.

But if a law is simply useful and does not involve any principle of natural justice, the prince is not bound by it, but can amend it or annul it altogether as he chooses, provided that with the alteration of the law the profit to some does not do damage to others without just cause. The prince then can annul an ordinance which is merely useful in order to substitute one more or less advantageous, for profit, honour, and justice all have degrees of more and less. And just as the prince can choose the most useful among profitable laws, so he can choose the most just among equitable laws, even though while some profit by them others suffer, provided it is the public that profits, and only the private individual that suffers. It is however never proper for the subject to disobey the laws of the prince under the pretext that honour and justice require it. ...

Edicts and ordinances therefore do not bind the ruler except in so far as they embody the principles of natural justice; that ceasing, the obligation ceases. But subjects are bound till the ruler has expressly abrogated the law, for it is a law both divine and natural that we should obey the edicts and ordinances of him whom God has set in authority over us, providing his edicts are not contrary to God's law. For just as the rear-vassal owes an oath of fealty in respect of and against all others, saving his sovereign prince, so the subject owes allegiance to his sovereign prince in respect of and against all others, saving the majesty of God, who is lord of all the princes of this world. From this principle we can deduce that other rule, that the sovereign prince is bound by the covenants he makes either with his subjects, or some other prince. Just because he enforces the covenants and mutual engagements entered into by his subjects among themselves, he must be the mirror of justice in all his own acts ... He has a double obligation in this case. He is bound in the first place by the principles of natural equity, which require that conventions and solemn promises should be kept, and in the second place in the interests of his own good faith, which he ought to pre-serve even to his own disadvantage, because he is the formal guarantor to all his subjects of the mutual faith they owe one another. ... 
A distinction must therefore be made between right and law, for one implies what is equitable and the other what is commanded. Law is nothing else than the command of the sovereign in the exercise of his sovereign power. A sovereign prince is not subject to the laws of the Greeks, or any other alien power, or even those of the Romans, much less to his own laws, except in so far as they embody the law of nature which, according to Pindar, is the law to which all kings and princes are subject. Neither Pope nor Emperor is exempt from this law, though certain flatterers say they can take the goods of their subjects at will. But both civilians and canonists have repudiated this opinion as contrary to the law of God. They err who assert that in virtue of their sovereign power princes can do this. It is rather the law of the jungle, an act of force and violence. For as we have shown above, absolute power only implies freedom in relation to positive laws, and not in relation to the law of God. God has declared explicitly in His Law that it is not just to take, or even to covet, the goods of another. Those who defend such opinions are even more dangerous than those who act on them. They show the lion his claws, and arm princes under a cover of just claims. The evil will of a tyrant, drunk with such flatteries, urges him to an abuse of absolute power and excites his violent passions to the pitch where avarice issues in confiscations, desire in adultery, and anger in murder. $\ldots$

Since then the prince has no power to exceed the laws of nature which God Himself, whose image he is, has decreed, he cannot take his subjects' property without just and reasonable cause, that is to say by purchase, exchange, legitimate confiscation, or to secure peace with the enemy when it cannot be otherwise achieved. Natural reason instructs us that the public good must be preferred to the particular, and that subjects should give up not only their mutual antagonisms and animosities, but also their possessions, for the safety of the commonwealth. ...

It remains to be determined whether the prince is bound by the covenants of his predecessors, and whether, if so, it is a derogation or his sovereign power ... A distinction must be made between the ruler who succeeds because he is the natural heir of his predecessor, and the ruler who succeeds in virtue of the laws and customs of the realm. In the first case the heir is bound by the oaths and promises of his predecessors just as is any ordinary heir. In the second case he is not so bound even if he is sworn, for the 
oath of the predecessor does not bind the successor. He is bound however in all that tends to the benefit of the kingdom.

There are those who will say that there is no need of such distinctions since the prince is bound in any case by the law of nations, under which covenants are guaranteed. But I consider that these distinctions are necessary nevertheless, since the prince is bound as much by the law of nations, but no more, than by any of his own enactments. If the law of nations is iniquitous in any respect, he can disallow it within his own kingdom, and forbid his subjects to observe it, as was done in France in regard to slavery. He can do the same in relation to any other of its provisions, so long as he does nothing against the law of God. If justice is the end of the law, the law the work of the prince, and the prince the image of God, it follows of necessity that the law of the prince should be modelled on the law of God.

Concerning Feudatory and Tributary Princes [CHAPTER IX]

A CHAPTER must be devoted to this subject, since formerly the rights of sovereignty were identical with feudal rights, such as are found throughout Europe and Asia ... We have already said that an absolute sovereign is one who, under God, holds by the sword alone. If he holds of another he is not sovereign. But this raises a difficulty. If those who hold anything at all of another in faith and homage are not sovereigns, there are hardly any sovereign princes in the world. On the other hand if we concede that those who do so hold in faith and homage are sovereigns, we are in effect saying the vassal and his lord, the servant and his master, are equals in honour, power, and authority. But it is a fact that civilians have treated the Dukes of Milan, Mantua, Ferrara, Savoy, and even certain counts as sovereigns, though this is not in the least consistent with the principle we have laid down. It is clear therefore that the matter needs examining, since it touches so closely upon the question of sovereignty, and the standing and honour of princes.

We have already shown in the chapter on protection that princes who are under the protection of, but not subject to another, remain sovereign, even though the alliance is an unequal one in that the protected must needs defer to the protector. But there is a great difference between being simply 
under the protection of another, and owing him faith and homage, by which I mean the oaths of fidelity, submission, service, and duty owed by a vassal to his lord.

There are in fact six degrees of dependence below the status of an absolute prince who holds of none and is dependent on none. First there is the tributary prince who is the inferior of him to whom he pays tribute, but nevertheless is a sovereign prince, since he is not in subjection to him. Though he may be more heavily burdened than a prince who is under protection, his status is nevertheless the higher, in that once the tribute which he has promised in order to secure peace is paid, he is quit of all further obligations, and may take what steps he pleases for the defence of his rights. Next in order is the prince who has commended himself to another for protection. His status is lower than that of either his protector or a tributary prince, for he cannot defend his rights save with the assistance of his protector, whose protégé and dependant he is, as has been shown in an earlier chapter. The third type is that of the prince who is a sovereign in his own realm and under no man's protection, but at the same time is the vassal of another prince for some fief, in respect of which he owes him the honour and service due on that fief. The fourth is the simple vassal who owes faith and service for his fief, but is neither a sovereign himself, nor the natural subject of the man of whom he holds the fief. The fifth is the liege-vassal of a sovereign prince but not his subject. The last is the natural subject, whether vassal or tenant, who holds his feudal or peasant holding of a sovereign prince who is his natural lord and has jurisdiction over him; it includes those who have neither fief nor lands, but are nevertheless justiciable by and subject to the prince of their native country.

I have made all these distinctions in order to clear up the very common confusion between the subject and the vassal, and between the simple vassal and the liege-vassal. The liege-vassal owes obedience to his lord in relation to and against all. The simple vassal reserves the rights of his lord's superior. But only the subject owes absolute obedience. The vassal, whether liege or simple, if he is not a subject, only owes the service and homage promised at his investiture, and can be quit of it by abandoning his fief without breach of faith. But the subject, whether vassal, tenant, free proprietor, or landless man cannot be quit of the authority of his prince 
against his prince's will, or without his consent, as has been shown in the chapter on the citizen. The simple vassal only takes the oath of submission to his lord once and there are even vassals who take no oath, for there are fiefs on which no homage is due. But a subject, whoever he is, whether vassal, tenant, free proprietor, landless man, or even a bishop without temporalities, must take an oath of submission to his sovereign prince whenever, and as often as, he chooses to demand it. As for liege-homage, one need not be the subject of the man to whom it is due, for a sovereign prince can hold a fief of another in respect of which he owes him liege-homage....

These considerations suggest that the only ruler who is sovereign in an absolute sense is one who holds nothing of any other prince, for the vassal, even if he is the Pope or the Emperor himself, if he holds any kind of fief, owes personal service to the man of whom he holds it. This term 'service', when used in relation to fiefs, is in no country prejudicial to the personal liberty of the vassal. Nevertheless it implies obligations, duties, honour, and reverence owed to the feudal overlord. These do not at all imply real servitude, but they are inseparably attached to the person of the vassal, so that he cannot escape them save by abandoning his fief, and only then if he is not the natural subject of his lord. In that case he cannot escape his subjection even in abandoning his fief... Can then a prince really be regarded as an absolute sovereign who takes the oath of homage, who is obliged to serve another, who is the man, or to speak more exactly, the servitor of another? ...

Bartolus once wrote that it was a kind of heresy to reject the claims of the Emperor to lordship of the world. Such a statement hardly requires refutation, seeing that Rome itself never ruled more than a thirtieth part of the globe, and the German Emperors only a tenth part of the Roman Empire ... Nevertheless the partisans of the Emperor on the one hand, and the Church on the other have claimed, the one for the Emperor, the other for the Pope, final sovereign authority over all Christian princes. Some have argued that all anointed kings are vassals of the Pope, others that the Pope is the guardian of all kings incapable of discharging their functions. Innocent IV, hearing that the King of Portugal neglected the interests of his realm, commanded the princes and barons of Portugal to choose a regent to take over the management of the finances and the administration, 'not', he said, 'that I intend to do anything to the prejudice of the crown, but rather to 
preserve its rights'. But his acts belied his words. Urban V presumed to legitimatize Henry, bastard of Castile, in order to give him grounds for expelling his legitimate brother Pedro from the kingdom, as he did. For Popes claimed the right of legitimization in respect of all princes. Others were prepared to go even further and ascribe to the Pope jurisdiction over the Emperor, and over all kings and princes, of right, and in fact, excepting only the Kings of France. Even canonists have admitted that in fact the latter acknowledge no superior save God alone. ...

But all these various claims rested on no surer foundation than the authority of Pope Gelasius,[10] who wrote that Popes could deprive kings of their authority. It was also claimed that there was an appeal from all kings and peoples to the Pope; that only an Emperor or a Pope could revoke their tides and deprive kings; that there was no prince rightly instituted unless the Pope had confirmed him in his principality; that the Pope could grant privileges, exemptions, and immunities to the subject regardless of the laws and customs of the realm, and that he was the sole judge of all exemptions. Finally it has been claimed that in virtue of the phrase de plenitudine potestatis used in Papal rescripts, the Pope can set aside the laws of all princes whatsoever. ...

I do not wish to enter into matters of religion, but to confine myself to the question of temporal sovereignty which is the subject of my discourse. This subject has not been discussed in a way which makes clear which princes are absolute sovereigns, and whether the rest are the subjects of either Pope or Emperor.

From the time that Pope Gregory, the one who first described himself as servant of the servants of God,[11] obtained from Phocas the Emperor in Constantinople authority over all the other bishops, his successors by using spiritual weapons for temporal ends gradually extended their power. Princes in their turn, more from piety towards God than respect for the Papal office, came to reverence its authority more and more ... In the end the Popes came to claim sovereignty not only in respect of spiritual matters, but also in temporal affairs, over all Christian princes. They acquired such rights in some cases by agreements and concessions, in others by usurpation and prescription, excepting only the kingdom of France, which always withstood such attempts, hard as the Popes tried to subject it to 
their authority....

[The rest of this very long chapter is devoted to a survey of the actualities of the political scene. Therefore, though he manifestly disapproved of the way the temporal power of the Popes had been built up, he admitted it as a fact. He regarded the Spanish kingdoms, Naples, Hungary, and Jerusalem together with many of the Italian city states as Papal fiefs. The rest of the Italian states, with the exception of Venice were Imperial fiefs. The New World was also held of the Pope in consequence of the Bull of Alexander VI. The Emperor he would not allow to be a sovereign prince anywhere. He either held of the Pope, or in Germany itself was subject to the Diet, for he regarded Germany as an aristocracy. His views on England are not so clear. It was a Papal fief till Henry VIII repudiated Papal authority. He says however in another place that feudal dependence was imprescriptible unless the fief was abandoned. Yet whereas in one place he speaks of the Swiss Cantons as originally fiefs of the Empire, he ends by describing them as absolute sovereign states, admitting no overlord. Of the Mohammedan world he says he has not enough evidence to discuss it, but he notices a passage in the Koran which forbids the title of Seigneur to any but the Caliph, and supposes that this is why no Mohammedan ruler wears a crown.

Tributary princes he hardly discusses, since by his own account it is a temporary status. He gives a few examples such as the tribute paid by Carthage to Rome, or by the Emperor Ferdinand to the Sultan in respect of the kingdom of Hungary. France alone emerges from this survey with an unqualified claim to be a sovereign state with no limitation whatsoever. In II. v [p. 67] however he lists France, Spain, England, Scotland, Ethiopia, Turkey, Persia, and Muscovy as absolute and sovereign monarchies.]

The True Attributes of Sovereignty [CHAPTER X]

BECAUSE there are none on earth, after God, greater than sovereign princes, whom God establishes as His lieutenants to command the rest of mankind, we must enquire carefully into their estate, that we may respect and revere their majesty in all due obedience, speak and think of them with all due honour. He who contemns his sovereign prince, contemns God whose image he is. ... 
Aristotle, Polybius, and Dionysius Halicarnassus alone among the Greeks discussed the attributes of sovereignty. But they treated the subject so briefly that one can see at a glance that they did not really understand the principles involved. I quote Aristotle. 'There are', he says, 'three parts of a commonwealth. There must be provision for the taking and giving of counsel, for appointing to office and assigning to each citizen his duties, for the administration of justice.' If he did not mean by parts attributes of sovereignty, he never treated of the subject at all, since this is the only passage which has any bearing. Polybius does not define the rights and duties of sovereignty either, but he says of the Romans that their constitution was a mixture of monarchy, aristocracy, and popular government, since the people made law and appointed to office, the Senate administered the provinces and conducted great affairs of state, the consuls enjoyed the pre-eminence of honour accorded to kings, especially in the field, where they exercised supreme command. This passage appears to imply a treatment of sovereign rights, since he says that those who enjoyed those rights had sovereign power. Dionysius Halicarnassus however had a clearer and better understanding of the matter than the others. When he was explaining how the King Servius deprived the Senate of authority, he observed that he transferred to the people the power to make and unmake law, to determine war and peace, to institute and deprive magistrates, and the right of hearing appeals from all courts whatsoever. In another passage, when describing the third conflict between the nobles and the people, he reported how the Consul Marcus Valerius rebuked the people and said that they should be content with the powers of making law, appointing to office and hearing appeals. Other matters should be left to the Senate.

Since ancient times civilians, and especially those of more recent years, have elaborated these rights, especially in their treatises on what they call regalian rights. Under this heading they have collected an immense number of particular rights and privileges enjoyed by dukes, counts, bishops, and various officials, and even subjects of sovereign princes. As a result they describe dukes, such as those of Milan, Mantua, Ferrara, and Savoy, and even counts, as sovereign princes. How ever reasonable it may appear, this is an error. How can these rulers be regarded as anything but sovereign, they argue, when they make law for their subjects, levy war and conclude peace, appoint to all office in their dominions, levy taxes, make a free man of whom they please, pardon those who have forfeited their lives. 
What other powers has any sovereign prince? But we have already shown above that the Dukes of Milan, Mantua, Ferrara, Florence, and Savoy hold of the Empire. Their most honourable title is that of Imperial Vicar and Prince of the Empire ... We have also pointed out the absurdities that ensue if one makes sovereigns of vassals, since the lord and his subject, the master and his servant, the man who makes the law and the man on whom it is imposed, the man who issues orders and the man who obeys them, are thereby placed on an equal footing. Since this cannot be, it follows that dukes, counts, and all those who hold of another, or are bound by his laws and subject to his commands, whether of right or by constraint, are not sovereign. The same holds good of the highest officers of state, lieutenant-generals of the king, governors, regents, dictators, whatever the extent of their powers. They are not sovereigns since they are subject to the laws and commands of another and may be appealed against.

The attributes of sovereignty are therefore peculiar to the sovereign prince, for if communicable to the subject, they cannot be called attributes of sovereignty ... Just as Almighty God cannot create another God equal with Himself, since $\mathrm{He}$ is infinite and two infinities cannot co-exist, so the sovereign prince, who is the image of God, cannot make a subject equal with himself without self-destruction.

If this is so, it follows that rights of jurisdiction are not attributes of sovereignty since they are exercised by subjects as well as the prince. The same is true of the appointment and dismissal of officials, for this power also the prince shares with the subject, not only in regard to the lesser offices of justice, of police, of the armed forces, or of the revenues, but also in regard to responsible commanders in peace and war ... The infliction of penalties and the bestowing of awards is not an attribute of sovereignty either, for the magistrate has this power, though it is true he derives it from the sovereign. Nor is taking counsel about affairs of state an attribute of sovereignty, for such is the proper function of the privy council or senate in the commonwealth, a body always distinct from that in which sovereignty is vested. Even in the popular state, where sovereignty lies in the assembly of the people, so far from it being the function of the assembly to take counsel, it ought never be permitted to do so, as I shall show later. 
It is clear therefore that none of the three functions of the state that Aristotle distinguishes are properly attributes of sovereignty. As for what Halicarnassus says about Marcus Valerius' speech to the people of Rome, when trying to pacify them, that they should be content with the prerogatives of making law and appointing magistrates, he does not make the point sufficiently clear. As I have already said, appointing to office is not an attribute of sovereignty. Moreover some further explanation is necessary of the nature of the law-making power. A magistrate can make laws binding on those subject to his jurisdiction, provided such laws do not conflict with the edicts and ordinances of his sovereign prince.

Before going any further, one must consider what is meant by law. The word law signifies the right command of that person, or those persons, who have absolute authority over all the rest without exception, saving only the law-giver himself, whether the command touches all subjects in general or only some in particular. To put it another way, the law is the rightful command of the sovereign touching all his subjects in general, or matters of general application ... As to the commands of the magistrate, they are not properly speaking laws but only edicts. 'An edict', says Varro, 'is an order issued by a magistrate.' Such orders are only binding on those subject to his jurisdiction, and are only in force for his term of office.

The first attribute of the sovereign prince therefore is the power to make law binding on all his subjects in general and on each in particular. But to avoid any ambiguity one must add that he does so without the consent of any superior, equal, or inferior being necessary. If the prince can only make law with the consent of a superior he is a subject; if of an equal he shares his sovereignty; if of an inferior, whether it be a council of magnates or the people, it is not he who is sovereign. The names of the magnates that one finds appended to a royal edict are not there to give force to the law, but as witnesses, and to make it more acceptable ... When I say that the first attribute of sovereignty is to give law to all in general and each in particular, I mean by this last phrase the grant of privileges. I mean by a privilege a concession to one or a small group of individuals which concerns the profit or loss of those persons only....

It may be objected however that not only have magistrates the power of issuing edicts and ordinances, each according to his competence and within 
his own sphere of jurisdiction, but private citizens can make law in the form of general or local custom. It is agreed that customary law is as binding as statute law. But if the sovereign prince is author of the law, his subjects are the authors of custom. But there is a difference between law and custom. Custom establishes itself gradually over a long period of years, and by common consent, or at any rate the consent of the greater part. Law is made on the instant and draws its force from him who has the right to bind all the rest. Custom is established imperceptibly and without any exercise of compulsion. Law is promulgated and imposed by authority, and often against the wishes of the subject. For this reason Dion Chrysostom compared custom to the king and law to the tyrant. Moreover law can break custom, but custom cannot derogate from the law, nor can the magistrate, or any other responsible for the administration of law, use his discretion about the enforcement of law as he can about custom. Law, unless it is permissive and relaxes the severity of another law, always carries penalties for its breach. Custom only has binding force by the sufferance and during the good pleasure of the sovereign prince, and so far as he is willing to authorize it. Thus the force of both statutes and customary law derives from the authorization of the prince ... Included in the power of making and unmaking law is that of promulgating it and amending it when it is obscure, or when the magistrates find contradictions and absurdities....

All the other attributes and rights of sovereignty are included in this power of making and unmaking law, so that strictly speaking this is the unique attribute of sovereign power. It includes all other rights of sovereignty, that is to say of making peace and war, of hearing appeals from the sentences of all courts whatsoever, of appointing and dismissing the great officers of state; of taxing, or granting privileges of exemption to all subjects, of appreciating or depreciating the value and weight of the coinage, of receiving oaths of fidelity from subjects and liege-vassals alike, without exception of any other to whom faith is due....

But because law is an imprecise and general term, it is as well to specify the other attributes of sovereignty comprised in it, such as the making of war and peace. This is one of the most important rights of sovereignty, since it brings in its train either the ruin or the salvation of the state.

This was a right of sovereignty not only among the ancient Romans, but has always been so among all other peoples... Sovereign princes are therefore 
accustomed to keep themselves informed of the smallest accidents and undertakings connected with warfare. Whatever latitude they may give to their representatives to negotiate peace or an alliance, they never grant the authority to conclude without their own express consent. This was illustrated in the negotiations leading up to the recent treaty of Câteaux-Cambrésis, when the king's envoys kept him almost hourly informed of all proposals and counter-proposals ... In popular states and aristocracies the difficulty of assembling the people, and the danger of making public all the secrets of diplomacy has meant that the people have generally handed responsibility over to the council. Nevertheless it remains true that the commissions and the orders that it issues in discharge of this function proceed from the authority of the people, and are despatched by the council in the name of the people....

The third attribute of sovereignty is the power to institute the great officers of state. It has never been questioned that the right is an attribute of sovereignty, at any rate as far as the great officers are concerned. I confine it however to high officials, for there is no commonwealth in which these officers, and many guilds and corporate bodies besides, have not some power of appointing their subordinate officials. They do this in virtue of their office, which carries with it the power to delegate. For instance, those who hold feudal rights of jurisdiction of their sovereign prince in faith and homage have the power to appoint the judges in their courts, and their assistants. But this power is devolved upon them by the prince ... It is therefore not the mere appointment of officials that implies sovereign right, but the authorization and confirmation of such appointments. It is true however that in so far as the exercise of this right is delegated, the sovereignty of the prince is to that extent qualified, unless his concurrence and express consent is required.

The fourth attribute of sovereignty, and one which has always been among its principal rights, is that the prince should be the final resort of appeal from all other courts... Even though the prince may have published a law, as did Caligula, forbidding any appeal or petition against the sentences of his officers, nevertheless the subject cannot be deprived of the right to make an appeal, or present a petition, to the prince in person. For the prince cannot tie his own hands in this respect, nor take from his subjects the 
means of redress, supplication, and petition, notwithstanding the fact that all rules governing appeals and jurisdictions are matters of positive law, which we have shown does not bind the prince. This is why the Privy Council, including the Chancellor de l'Hôpital, considered the action of the commissioners deputed to hold an enquiry into the conduct of the President l'Alemant[12] irregular and unprecedented. They had forbidden him to approach within twenty leagues of the court, with the intention of denying him any opportunity of appeal. The king himself could not deny this right to the subject, though he is free to make whatsoever reply to the appeal, favourable or unfavourable, that he pleases ... Were it otherwise, and the prince could acquit his subjects or his vassals from the obligation to submit their causes to him in the last instance, he would make of them sovereigns equal with himself... But if he would preserve his authority, the surest way of doing so is to avoid ever devolving any of the attributes of sovereignty upon a subject. ...

With this right is coupled the right of pardoning convicted persons, and so of overruling the sentences of his own courts, in mitigation of the severity of the law, whether touching life, property, honour, or domicile. It is not in the power of any magistrate, whatever his station, to do any of these things, or to make any revision of the judgement he has once given ... In a well-ordered commonwealth the right should never be delegated either to a special commission, or to any high officer of state, save in those circumstances where it is necessary to establish a regency, either because the king is abroad in some distant place, or in captivity, or incapable, or under age. For instance, during the minority of Louis IX, the authority of the Crown was vested in his mother Blanche of Castile as his guardian ... Princes however tend to abuse this right, thinking that to pardon is pleasing to God, whereas to exact the utmost punishment is displeasing to Him. But I hold, subject to correction, that the sovereign prince cannot remit any penalty imposed by the law of God, any more than he can dispense any one from the operation of the law of God, to which he himself is subject. If the magistrate who dispenses anyone from obedience to the ordinance of his king merits death, how much more unwarrantable is it for the prince to acquit a man of the punishment ordained by God's law? If a sovereign prince cannot deny a subject his civil rights, how can he acquit him of the penalties imposed by God, such as the death penalty exacted by divine law for treacherous murder? 
It may be objected that the prince can never show the quality of mercy if he cannot remit punishments prescribed by divine law. But in my opinion there are other means of showing clemency, such as pardoning breaches of positive laws. For instance, if the prince forbids the carrying of arms, or the selling of foodstuffs to the enemy in time of war, on pain of death, he can very properly pardon the offence of carrying arms if it was done in self-defence, or the selling of provisions if done under the pressure of extreme poverty. Again, the penalty for larceny under the civil law is death. A merciful prince can reduce this to fourfold restitution, which is what is required by divine law. It has always been the custom among Christian kings to pardon unpardonable offences on Good Friday. But pardons of this kind bring in their train pestilences, famine, war, and the downfall of states. That is why it is said in the law of God that in punishing those who have merited death one averts the curse on the whole people. Of a hundred criminals only two are brought to justice, and of those brought to justice only one half are proved guilty. If the few proven cases of guilt are pardoned, how can punishment act as a deterrent to evil-doers?... The best way for a prince to exercise his prerogative of mercy is to pardon offences against his own person. Of all exercises of mercy none is more pleasing to God. But what can one hope of the prince who cruelly avenges all injuries to himself, but pardons those inflicted on others? ...

Faith and homage are also among the most important attributes of sovereignty, as was made clear when the prince was described as the one to whom obedience was due without exception.

As for the right of coinage, it is contained within the law-making power, for only he who can make law can regulate currency. This is illustrated in the very terms used by Greeks, Romans, and French alike, for the word nummus comes from the Greek nomos signifying both law and alloy. There is nothing of more moment to a country, after the law, than the denomination, the value, and the weight of the coinage, as we have already shown in a separate treatise.[13] Therefore in every well-ordered commonwealth the prince reserves this right exclusively to himself... And although in this kingdom many private persons, such as the Vicomte de Touraine, the Bishops of Meaux, Cahors, Agde, Ambrun and the Counts of St. Pol, de la Marche, Nevers, Blois, and others enjoyed this right, Francis I in a general edict cancelled all such rights whatsoever, declaring the concessions null and void. This right 
and attribute of sovereignty ought not ever to be granted to a subject. ...

The right of levying taxes and imposing dues, or of exempting persons from the payment of such, is also part of the power of making law and granting privileges. Not that the levying of taxation is inseparable from the essence of the commonwealth, for as President Le Maître has shown, there was none levied in France till the time of Louis IX. But if any necessity should arise of imposing or withdrawing a tax, it can only be done by him who has sovereign authority ... It is true that many seigneurs have prescriptive rights of levying tallages, dues, and imposts. Even in this kingdom many seigneurs can levy tallage on four occasions in virtue of privileges confirmed by judgements in the courts, and by custom. Even seigneurs who have no rights of jurisdiction enjoy this privilege. But in my opinion the privilege started as an abuse which in consequence of long years of enjoyment acquired the dignity of a prescriptive right. But there is no abuse, of however long standing, that the law cannot amend, for the law exists to amend all abuses. Therefore, by the Edict of Moulins[14] it was ordained that all rights of tallage claimed by seigneurs over their dependants could no longer be levied, nothwithstanding immemorial prescription....

I have left out of this discussion those lesser prerogatives that individual sovereign princes claim in their own particular realms, as I have confined myself to those general attributes of sovereignty proper to all sovereign princes as such, but which, being inalienable and imprescriptible, cannot, of their very nature, be communicated to subordinate persons such as feudal lords, magistrates, or subjects of any degree whatsoever. Whatever grant a sovereign prince makes of lands or jurisdiction, the rights of the crown are always reserved. This was implied in a judgement of the High Court relating to appanages in France, that no passage of time could justify the usurpation of royal rights. If common lands cannot be acquired by prescription, how can the rights and attributes of sovereignty? It is certain, on the evidence of various edicts and ordinances, that the public domain is inalienable, and cannot be acquired by prescription. Over two thousand years ago Themistocles, in recovering common lands occupied by private persons, said in his speech to the people of Athens that men could acquire no prescriptive rights against God nor private citizens against the commonw ealth. ... 
Such are the principal characteristics of sovereign majesty, treated as briefly as possible, since I have already written at greater length on the subject in my book De Imperio.[15] It is most expedient for the preservation of the state that the rights of sovereignty should never be granted out to a subject, still less to a foreigner, for to do so is to provide a stepping-stone whereby the grantee himself becomes the sovereign.

1. The Anabaptist movement in the Low Countries and in Germany in the sixteenth century caused widespread fear and anger out of all proportion to its real threat, because the doctrine that the visible Church consisted of a congregation of the elect, or those illuminated by the inner light, under a shepherd, challenged all officially organized and inclusive Churches whether Catholic, Lutheran, or Calvinist. Attention centred on Münster where there was such a congregation of Anabaptists that they established control over the nominally episcopal city. They took as their second leader in 1534, John of Leyden, who established a régime of communism and polygamy. It took an army raised by the Diet, and a seige of eighteen months, to capture the city, when John of Leyden was executed and the community dissipated. Bodin returns several times to the episode as a good illustration of all that he disapproved of. See p. 112 and p. 143.

2. Methodus ad facilem historiarum cognitionem, chap. VI (1566). Translated by B. Reynolds in the Records of Civilization, No. XXXVII, published by Columbia University as The Method for the Easy Comprehension of History.

3. The term used is cite in the sense of the Latin civitas or the contemporary Italian città, a city-state centred in a town, but including all the inhabitants of the surrounding district under its jurisdiction.

4. Ei et in eum omnem potestatem contulit.

5. Nulla obligatio consistere potest, quae a voluntate promittentis statum capit.

6. There is a marginal reference to Innocent IV. 
7. The term used is 'lois royales'.

8. A reference to Théodore Béza, Du droit des Magistrats, 1576 ?

9. These Estates met in 1484 after the death of Louis XI. Despite the opportunity offered by the dispute over the regency, the only matter pressed by them was a reduction of the tailles to the lower scale of the times of Charles VII. Though concessions were made to this effect, the government made no surrender in principle of its absolute control of finance. The stand made by de Comines earned him dismissal from office and five years' imprisonment.

10. This must be a reference to Gelasius I, 493-96, whose pronouncements on the separation of powers were incorporated in the Canon Law. Bodin was however ascribing to St. Gelasius views developed by medieval popes, for he only claimed priority in dignity not in power for the spiritual authority, and spoke of priestly authority and imperial authority as such, and not popes and kings. Gelasius II, 1118-19, held the views Bodin described, but when he declared the Emperor Henry V deposed, he was no innovator, but only acting upon the precedent set by Gregory VII in deposing Henry IV,

11. Gregory I, 590-603.

12. I have been unable to identify this episode.

13. This treatise was published three times under different titles. In 1568 as Réponse au paradoxe de Monsieur de Malestroict, in 1574 as Discours sur les causes de l'extrème cherté qui est aujourd'hui en France, and in 1578 as Discours de Jean Bodin sur le rehaussement et diminution des Monnaies. In 1591 a Latin translation appeared.

14. The Ordinance of Moulins, 1566, was an important measure dealing with many aspects of the administration of justice, including feudal and ecclesiastical privilege.

15. This has not survived. In his will Bodin directed that many of his earlier or less important works should be destroyed. The De Imperio belongs to the Toulouse period, and was probably a sketch of parts of the Six books 
of the Commonwealth.

\section{BOOK II}

\section{Of the Different Kinds of Commonwealth [CHAPTER I]}

Now that we have determined what sovereignty is, and have described its rights and attributes, we must consider in whom it is vested in every kind of commonwealth, in order to determine what are the various possible types of state. If sovereignty is vested in a single prince we call the state a monarchy. If all the people share in it, it is a popular state. If only a minority, it is an aristocracy.

It is desirable to be exact in the use of these terms in order to avoid the confusion which has arisen as a result of the great variety of governments, good and bad. This has misled some into distinguishing more than three kinds of commonwealth. But if one adopts the principle of distinguishing between commonwealths according to the particular virtues and vices that are characteristic of each, one is soon faced with an infinity of variations. It is a principle of all sound definition that one should pay no regard to accidental properties, which are innumerable, but confine oneself to formal and essential distinctions. Otherwise one becomes entangled in a labyrinth which defies exact analysis. For there is no reason why one should stop short at the difference between good and bad. There are other inessential variations. A king can be chosen for his strength, his beauty, his fame, his noble birth, his wealth, all of them matters of indifference. Or he may be chosen because he is the most warlike or most peace-loving, the wisest, the most just, a lover of display, of great learning, the most prudent, the most modest, the simplest, the most chaste. One could add to the list indefinitely and arrive at an infinity of types of monarchy. It would be the same in the case of aristocracies. The ruling class might be drawn from the rich, the nobles, or those esteemed as wise, or just, or warlike. Moreover, one would have to make a similar reckoning of bad qualities. The result would be merely absurd, and for this reason such a method of classification must be rejected. 
Since then the nature of things is not changed by their accidental properties, we conclude that there are only three types of state, or commonwealth, monarchy, aristocracy, and democracy. A state is called a monarchy when sovereignty is vested in one person, and the rest have only to obey. Democracy, or the popular state, is one in which all the people, or a majority among them, exercise sovereign power collectively. A state is an aristocracy when a minority collectively enjoy sovereign power and impose law on the rest, generally and severally.

All the ancients agree that there are at least three types of commonwealth. Some have added a fourth composed of a mixture of the other three. Plato added a fourth type, or rule of the wise. But this, properly speaking, is only the purest form that aristocracy can take. He did not accept a mixed state as a fourth type. Aristotle accepted both Plato's fourth type and the mixed state, making five in all. Polybius distinguished seven, three good, three bad, and one composed of a mixture of the three good. Dionysius Halicarnassus only admitted four, the three pure types, and a mixture of them. Cicero, and following his example, Sir Thomas More in his

Commonwealth, Contarini,[1] Machiavelli,[2] and many others have held the same opinion. This view has the dignity of antiquity. It was not new when propounded by Polybius, who is generally credited with its invention, nor by Aristotle. It goes back four hundred years earlier to Herodotus. He said that many thought that the mixed was the best type, but for his part he thought there were only three types, and all others were imperfect forms. I should have been convinced by the authority of such great names, but that reason and common sense compels me to hold the opposing view. One must show then not only why these views are erroneous but why the arguments and examples they rely on do not really prove their point. ...

If sovereignty is, of its very nature, indivisible, as we have shown, how can a prince, a ruling class, and the people, all have a part in it at the same time? The first attribute of sovereignty is the power to make law binding on the subject. But in such a case who will be the subjects that obey, if they also have a share in the law-making power? And who will be the law-giver if he is also himself forced to receive it from those upon whom he has imposed it? One is forced to the conclusion that if no one in particular has the power to make law, but it belongs to all indifferently, then the commonwealth is a popular state. If power is given to the people to make 
law, and appoint to office, but all other powers are denied them, it must nevertheless be recognized that these other powers, vested in officials, really belong to the people, and are only entrusted by them to the magistrates. The people, having instituted the latter, can also deprive them, and the state therefore remains a popular one. In order to confirm what I have just said, let us look more closely at the examples of mixed states cited by Polybius, Contarini and others. ...

One of the examples given is Rome, whose constitution, it is alleged, was a mixture of monarchy, democracy, and aristocracy, in such a way that according to Polybius the Consuls embody the monarchical principle, the Senate the aristocratic, the Estates of the people the democratic. Halicarnassus, Cicero, Contarini, and others have accepted this analysis, inaccurate as it is. In the first place monarchical power cannot subsist in two persons simultaneously, since monarchy by definition is the rule of one. If it is divided, there is either no monarchy, or no kingdom. One could, with more reason, describe the Doge of Genoa or Venice as a monarch. But in any case what kingly power could be ascribed to the Consuls, seeing that they could not make law, declare war and peace, appoint any officials, pardon any offenders, spend a penny of public money, or even condemn a citizen to corporal punishment except in time of war? This last power belongs to any leader in the field. These would also have to be called kings, and with more reason. The Constable in this realm, and the great Pascha in Turkey have ten times the power of the two Consuls put together, yet they are no more than the subjects and slaves of the prince, as the Consuls were of the people. ...

Again, conduct of affairs of state undertaken by the Senate, and the decisions reached by it, had no force unless confirmed by the people, or assented to by the tribunes, as will be explained more fully when we come to deal with the council in the state. There can be no real doubt that the Roman constitution, from the moment that the kings were expelled, was popular, except for the two years of the Decemvirate, erected to revise the laws and customs. This temporarily converted the constitution into an aristocracy, or rather, oligarchy. I have said above that the authority of magistrates, of whatever degree they may be, is never properly their own, but enjoyed by them as a trust. It is clear that the people originally elected the Senate, but in order to get rid of the burden of so doing, they 
committed this power to the censors, who were, of course, also elected by the people. Thus all the authority of the Senate derived from the people. The people were accustomed to confirm or annul, ratify or veto the decisions of the Senate according to their good pleasure.

Contarini has analysed the Republic of Venice in the same way, describing it as a mixture of three pure types, as was that of Rome. He identifies royal power with that of the Doge, aristocratic with the Senate, and popular with the Great Council... But it is only a small minority of Venetians, drawn from noble families, that enjoys sovereign power. By no means all gentlemen who are natives of Venice are participants, for some of these citizens are eligible for the Great Council and others are not, although they may be of the same extraction, the same kin, and even bear the same names. I need not explain how this comes to be so, for it is all in Sabellico.[3] The Great Council, says Contarini, has power to make and unmake laws, institute and deprive officials, hear appeals, determine peace and war, pardon the convicted. But in saying this Contarini is condemned out of his own mouth. If it is as he says, it follows that the constitution of the Republic is an aristocracy, even though the Great Council's only direct power is the institution to office, for whatever power these officials enjoy, they hold them in trust. It follows that neither the Ten, nor the Senate, nor the Ministers of State, nor even the Doge himself with the six ducal councillors have any authority save by commission, and depend on the good pleasure of the Great Council....

There are those who say, and have published in writing, that the constitution of France is a mixture of the three pure types, the Parlement representing aristocracy, the Estates-General democracy, and the King monarchy. [4] But this is an opinion not only absurd but treasonable. It is treasonable to exalt the subjects to be the equals and colleagues of their sovereign prince. And what resemblance is there to a popular form of government in the Estates, seeing that each particular member and all in general, kneel in the king's presence, and address him by humble prayers and supplications, which he accepts or rejects as he thinks fit. What counter-weight of popular sovereignty can be set against the monarchy in an assembly of the three estates, or even an assembly of the entire people, were that physically possible, seeing that they approach the king with supplication and entreaty, and address him in terms of reverence? So far 
from diminishing the power of a sovereign prince, such an assembly enhances and emphasizes it. The king can attain no higher degree of honour, power, and glory, than he enjoys at the moment when an infinite number of princes and seigneurs, an innumerable multitude of people of all sorts and conditions, cast themselves at his feet, and pay homage to his majesty. The honour, glory, and power of princes lies in the obedience, homage, and service of their subjects.

If then there is no vestige of popular sovereignty in the assembly of the three estates of this realm, no more, or even less, than there is in those of Spain and England, still less is there any trace of aristocratic authority either in the Court of Peers, or any assembly of the officers of the kingdom, seeing that in the king's presence the authority of all corporations and colleges, of all officers of the realm collectively or severally, is suspended, so that no magistrate whatsoever has power to issue commands in his presence, as we shall show in due course. ...

But, someone may say, could you not have a commonwealth where the people appointed to office, controlled the expenditure of the revenue and had the right of pardon, which are three of the attributes of sovereignty; where the nobles made laws, determined peace and war, and levied taxes, which are also attributes of sovereignty; and where there was a supreme magistrate set over all the rest, to whom liege-homage was due by all the people severally and collectively, and who was the final and absolute resort of justice. Would not such arrangements involve a division of sovereign rights, and imply a composite commonwealth which was at once monarchical, aristocratic and popular? I would reply that none such has ever existed, and could never exist or even be clearly imagined, seeing that the attributes of sovereignty are indivisible. Whoever could make laws for all the rest, that is to say command or forbid whatever he wished, without there being any right to appeal against or resist his orders, could forbid the declaration of war, the levying of taxes, the swearing of oath s of fealty, without his consent. Or the man to whom liege-homage was due could forbid both nobles and people from obedience to any person but himself. Such situations could only be resolved by an appeal to arms, until by this means it was decided whether final authority remained in the prince, or a ruling class, or in the people ... Since the King of Denmark has been compelled to share sovereign power with the nobility, that kingdom has never enjoyed any secure peace. The same 
is true of Sweden, where the King is so mistrustful of the nobles that he employs a German as Chancellor, and a Norman gentleman called Varennes as Constable....

There is just one other point to be considered. The Republic of Rome, under the Empire of Augustus, and for long after, was called a principality. This appears to be a form of commonwealth not mentioned by Herodotus, Plato, Aristotle or even Polybius, who enumerated seven ... But I would reply that in many aristocratic or popular states one particular magistrate has precedence over all the rest in dignity and authority. Such are the Emperor in Germany, the Doge in Venice, and in ancient times the Archon in Athens. But this does not change the form of the state ... A principality is nothing but an aristocracy or a democracy which has a single person as president or premier of the republic, but who nevertheless holds of those in whom sovereign power resides.

\section{Concerning Despotic Monarchy [CHAPTER II]}

... ALL monarchies are either despotic, royal, or tyrannical. These however are not different species of commonwealth, but different modes of operation in their governments. It is important that a clear distinction be made between the form of the state, and the form of the government, which is merely the machinery of policing the state, though no one has yet considered it in that light. To illustrate, a state may be a monarchy, but it is governed democratically if the prince distributes lands, magistracies, offices, and honours indifferently to all, without regard to the claims of either birth or wealth or virtue. Or a monarchy can be governed aristocratically when the prince confines the distribution of lands and offices to the nobles, the most worthy, or the rich, as the case may be. Again, an aristocracy can conduct its government democratically if it bestows honours and rewards on all alike, or aristocratically if it reserves them for the rich and nobly born. This variety in forms of government has misled those who have written confusedly about politics, through failure to distinguish the form of the commonwealth from the form of the government.

Royal, or legitimate, monarchy is one in which the subject obeys the laws of the prince, the prince in his turn obeys the laws of God, and natural liberty and the natural right to property is secured to all. Despotic 
monarchy is one in which the prince is lord and master of both the possessions and the persons of his subjects by right of conquest in a just war; he governs his subjects as absolutely as the head of a household governs his slaves. Tyrannical monarchy is one in which the laws of nature are set at naught, free subjects oppressed as if they were slaves, and their property treated as if it belonged to the tyrant. Exactly the same diversity is to be found in aristocracies and popular states, for each in its turn can be either legitimate, despotic, or tyrannical in the way I have described.

Despotic monarchy must be considered first, as it is the earliest kind of government known to men. They are in error who accept Aristotle's opinion that the primitive kings of heroic times were elected by the people. We have evidence that the first monarchy that ever came into being arose in Assyria, in the time of Nimrod.[5] The Scriptures speak of him as the mighty hunter, which in Hebrew is a common way of referring to a robber. Aristotle and Plato themselves include brigandage as a form of the chase. Before Nimrod's time there was none who had authority or domination over others. His very name indicates his character, for Nimrod signifies 'terrible and mighty lord'. Not long after his time, during the life of Shem, Noah's son, the world was found to be full of slaves, and throughout the Scriptures the subjects of the Kings of Assyria and Egypt are always referred to as slaves. The Greeks too were convinced that whereas they themselves were free, the barbarians were enslaved, and by barbarians they meant the inhabitants of Persia and Asia. When the Kings of Persia made war, they always laid claim to both land and water, by way of indicating, says Plutarch, that they were the absolute lords of all property and all persons whatsoever. ...

Despotic monarchy must not be confused with tyranny. There is nothing unfitting in a prince who has defeated his enemies in a good and just war, assuming an absolute right to their possessions and their persons under the laws of war, and thereafter governing them as his slaves; just as the head of a household is the master of his slaves and their goods, and disposes of them as he thinks fit, under the law of nations. But the prince who by an unjust war, or any other means, enslaves a free people and seizes their property, is not a despot but a tyrant...

Nowadays, by comparison with the number of tyrannies, there are few despotic 
monarchies save in Asia, Ethiopia, and those parts of Europe governed by the Kings of Tartary and of Muscovy. According to the History of Muscovy[6] the subjects are called chlopes which means slaves ... Elsewhere in Europe, and in the kingdoms of Barbary, I know of no despotic monarchies... The people of Europe are prouder and more belligerent than the inhabitants of Asia and of Africa, and have never submitted to despotic rule since the Hungarian invasions. Thus Odovacer, who ruled at that time, took a third part of the lands of the vanquished when he subdued Italy, in accordance with the usual penalty inflicted on a conquered people. But he left them their freedom, and absolute control of the property that remained to them, without dues, or oaths of fidelity, or homage whatsoever. But subsequently the Germans, the Lombards, the Franks, Saxons, Burgundians, Goths, Ostrogoths, Angles, and other tribes, having experienced the customs of the oriental Hungarians, began to conduct themselves as lords and masters, not, it is true, of the persons of the conquered peoples, but of their property. They then gradually established rights of overlordship of land, and claims to faith and homage, and other rights knowns as feudal rights, thereby perpetuating the shadow, though in a very attenuated form, of the primitive despotic monarchies...

It may occur to someone to object that despotic monarchy is really a tyranny, seeing that it is a violation of the law of nature to deny anyone his personal liberty, and the free disposal of his own goods. I agree that it is against the law of nature to enslave a free man, and to seize the goods of another. But there is, and always has been, universal agreement that what is won in a just war is the property of the victor, and that the vanquished are his slaves. A monarchy so established is not a tyranny. We read in Holy Writ that Jacob left property to his children by will, which he claimed as his own because he had won it by force of arms. Moreover the custom whereby it is recognized that there can be no just war where there is a superior to settle disputes, implies that where there is no superior, recourse to arms is justified. This is illustrated in Germany, where the Princes and Imperial Free Cities are subjected to the imperial ban if they will not restore that which they have seized from another. Otherwise, if we make no distinction between despotism and tyranny, we can make no distinction between rights of war against an enemy and theft, between the just prince and the brigand, between a war justly undertaken and a mere exercise of violence. 
Generally speaking we find that tyrannies quickly come to ruin, but that despotic states and despotic monarchies have proved both great and enduring, such as the monarchies of the Assyrians, the Medes, Persians, and Egyptians in ancient times, and in our own day that of Ethiopia where, if we are to believe Paolo Giovio, the Negus commands fifty kings as his subject slaves.[7] The reason why despotic monarchy is more lasting than the others is that it is the most authoritative. The lives, the goods, the liberty of the subjects are at the absolute disposal of the prince who has conquered them in a just war. This greatly discourages unruliness in the subject. As with slaves, awareness of their condition makes them humble, timid, 'servile' as they say. But men who are free, and masters of what is their own, resent any attempt to enslave them or take their property. They are quick to resist, not being debased by servitude, because they have the courageous spirit that is born of freedom. So much for despotic monarchy. Let us now consider royal monarchy.

Concerning Royal Monarchy [CHAPTER III]

A TRUE king is one who observes the laws of nature as punctiliously as he wishes his subjects to observe his own laws, thereby securing to them their liberty, and the enjoyment of their own property. I have added these last qualifications in order to distinguish kingship from despotism. A despot can be a just and virtuous prince, and an equitable governor of his people, but he is the master of their persons and their goods. If a despot who has overcome his enemies in a just war, restores to them their liberty, and permits them to dispose of themselves and their possessions as they wish, he ceases to be a despot and becomes a king....

In defining royal monarchy I have said that the subjects should obey the king, to make it clear that sovereign majesty is vested in him, and I have said that the king should obey the laws of nature, to show that he should govern in accordance with the principles of natural justice, which are as obvious, as clear and illuminating as the light of the sun.

It is therefore the authentic mark of kingship that the prince is as mild and pliable to the laws of nature as he wishes his subjects to be to him. This means that he is one that fears God, is merciful to the afflicted, prudent in his undertakings, brave in action, modest in prosperity, constant 
in adversity, true to his plighted word, wise in council, careful of his subjects, helpful to his friends, terrible to his enemies, courteous to men of good birth, a scourge of evil-doers, and just towards all. In such a state there is the rule of law rather than of men, or as Pindar puts it, the law is king, since the prince obeys the laws of nature, and the people the civil laws. The result is a condition of mutual harmony between the king and his obedient subjects, and a happy and unforced agreement the one with the other.

Monarchy so conducted is properly called royal and legitimate. This is so whether the king succeeds by hereditary right as did the ancient kings, as Thucydides truly observes; or whether the succession is governed by some law excluding women and their heirs male, as is the case in this kingdom under the salic law; or whether the king is elected as Aristotle says was the case with primitive kings (though in this case he ignores the truths of history, and what Thucydides himself records), and still is the case in many northern kingdoms; or whether the crown is received as a free gift, as when Augustus gave Numidia, recently reduced to a subject province of the Empire, to Juba the Younger, or when the kingdom of the Sicilies was given first to Charles of France, and then to Louis of France, Duke of Anjou; or whether it is disposed of by will, as is the custom in the kingdoms of Thunes, Fez, and Morocco, and as was done by Henry VIII, King of England, who left the crown first to his son Edward, and then to Mary and then Elizabeth, who later succeeded (though in this case the will was ratified by the people). If a man seize the crown by subtle practices, as did Cecrops, Hiero, and Gelo according to Pindar, and in our own times Cosimo de' Medici, Duke of Florence,[8] he is a king if he reigns justly ... Even if he conquers his kingdom by force of arms, rightly or wrongly, provided that he rules the people so conquered equitably, he is a true king, as Livy said of King Servius. In fact, one often finds that a robber and brigand turns into a virtuous prince, and a violent tyranny becomes a just monarchy ... Monarchies cannot be distinguished one from another by the method of succession, but only by the way they are conducted, and of these there are only the three varieties, despotic, royal, and tyrannical ... So much for royal monarchy. Let us turn to tyranny.

Concerning Tyrannical Monarchy [CHAPTERS IV AND V] 
A TYRANNICAL monarchy is one in which the monarch tramples underfoot the laws of nature, in that he abuses the natural liberty of his subjects by making them his slaves, and invades the property of others by treating it as his own. The word tyrant, which in Greek was originally an honourable term, merely signified the prince who had come into power without the goodwill of his subjects, and from being an equal had raised himself to be their master. Such a one, even though he proved a wise and just prince, was called a tyrant. Plato, writing to the tyrant Dionysius, addressed him in that style as a mark of respect, 'Plato to the tyrant Dionysius, greeting'. The fact that Pittacus and Penander, who were numbered among the seven sages of Greece, were called tyrants because they had seized the government of their realms, is sufficient proof that the term was used of good as well as bad rulers.

But those who by force or fraud had seized sovereign power soon found that their lives were exposed to the vengeance of their rivals, and were compelled for their own safety to employ foreigners as a bodyguard, and to build great fortresses as a refuge. Their upkeep then compelled them to levy heavy taxes and imposts. Discovering nevertheless that their friends were weak and their enemies powerful, they were prompted to put to death or to banish the latter to enrich the former. The most abandoned ravished not only goods, but women and children. The consequence was that tyrants became loathed and detested. We read that Dionysius the Elder, tyrant of Syracuse, maintained a guard of ten thousand foot and ten thousand horse, besides four hundred armed galleys. He could rely on the loyalty of so few citizens that he forbad them to meet together, even for private banquets, however closely the participants might be related to one another, and he encouraged assaults on anyone going home from such a gathering. Nevertheless Plutarch admits that he was a good ruler, and governed better and more justly than many princes who styled them selves kings....

But it is possible that the same man may conduct himself as a despot to some of his subjects, a king to others and a tyrant to the rest. For instance he may tyrannize over the rich and the nobility, but be a beneficent protector of the poor. For tyranny is always a matter of degree, more or less. There is no prince, however worthy, who has not some notable vice. There is no tyrant, however cruel, who has not some virtue, or laudable quality. For this reason it is most ill-advised and dangerous to condemn a prince without 
a proper understanding of his conduct, and without balancing his good deeds against his bad, his heroic exploits against his mortal wickednesses. The Persians for instance never condemned anyone till it could be shown that the evil that he did outweighed the good.

In contrasting the king and the tyrant therefore we must take the extreme cases of the good and just king, and the utterly detestable tyrant, to make the distinction between them clear. But be it noted that by a good and just king I mean one who is popularly accepted as such, and not some impossible ideal figure of heroic proportions, or a paragon of wisdom, justice, and piety, without blame or reproach. Such perfection is all too rare. I mean by a good and just king one who consistently strives to be such, and who puts all that he has, even to his life's blood, at the service of his people.

Such were a Codrus, or a Decius. Apprehending that victory depended on their deaths, they forthwith laid down their lives. But best of all examples is that of Moses, whom Philo calls the wise legislator, just king, and great prophet. He prayed God the rather to blot out his name from the book of life than that the people should go unpardoned, preferring rather his own damnation than that the people should perish. Here indeed is the likeness of the true prince and the father of his people.

The most notable distinction between the king and the tyrant is that the king conforms to the laws of nature and the tyrant tramples them underfoot. The one is guided by piety, justice, and faith. The other denies his God, his faith, and the law. The one does that which he believes will further the common good, and the welfare of his subjects. The other consults only his own profit, vengeance, or pleasure. The one tries to enrich his subjects by any means he can discover. The other builds his prosperity on the ruin of other people's. The one avenges injuries done to his subjects but pardons those committed against himself. The other takes a cruel revenge for injuries done to himself but pardons those done to others. The one encourages free speech on the part of his subjects to the point of wise rebuke when he has failed in his duty. The other dislikes none so much as the serious, free-spirited, and virtuous citizen. The one tries to keep his subjects in peace and unity among themselves. The other sows dissensions, that his subjects may ruin one another, and he himself grow rich on the profits thereof. The one takes pleasure in being seen and heard by his subjects. The other shuts himself away as from his mortal enemies. The one 
bases his rule on the love of his people, the other on their fear. The one only imposes burdens on his people when absolutely necessary, and is as moderate as possible in his demands. The other sucks the marrow from the bones of his subjects, and bleeds them white to keep them weak. The one seeks out upright men to fill the public offices. The other sells them to the highest bidder in order to vex his subjects by setting robbers on them, and then executes the thieves in order to get himself the reputation of a just ruler. The one conforms his conduct to the laws, the other makes the laws subserve his convenience. The one is loved and revered by his subjects, the other is hated by all and hates all. The one appeals to the assistance of his own subjects in time of war, and keeps no garrison unless they man it. The other makes war on his subjects and surrounds himself with foreign guards. The one lives in peace and security, in expectation of eternal felicity, honoured in this life and regretted after death. The other drags out his existence in perpetual terror, without the hope of escaping eternal punishment, defamed while alive, and cursed after his death. There is no need to verify all these truths by a wealth of examples, for they are known to all....

One must not however label as evidence of tyranny the executions, banishments, confiscations and other deeds of violence that mark a revolution or restoration in a commonwealth. Such changes are necessarily violent, as was illustrated by what happened at the establishment of the Trium virate in Rome, and at the election of many of the Emperors. It is not proper, either, to call Cosimo de' Medici a tyrant for building a citadel, surrounding himself with foreign guards, and taxing his subjects heavily for their upkeep, after the assassination of Alessandro, Duke of Florence. Such medicine was necessary to a commonwealth ravaged by so many seditions and insurrections, and for a licentious and unruly populace, everlastingly plotting against the new duke, though he was accounted one of the wisest and most virtuous princes of his age. On the contrary it often happens that mildness in a prince would ruin a commonwealth, whereas severity saves it. It is sufficiently notorious that the tyranny of Domitian was terrible to the Senate, the nobles, the great lords, and governors of the Roman Empire. Nevertheless after his death he was held in great honour by the provincials, for never had they known better officers and magistrates, kept in awe as these had been by fear of the Emperor. ... 
Those who go about uttering extravagant praises of princes who are mild, gracious, courteous, and simple, are greatly in error. Simplicity without prudence is dangerous and pernicious in a king, and much more to be dreaded than the cruelty of a severe, close-fisted, and inaccessible prince. Our forefathers did not without reason coin the phrase 'a bad man makes a good king'. This sounds strange to sensitive ears, and to those not accustomed to weigh one thing against another. The tolerance and foolish simplicity of too good a prince admits flatterers, place-hunters, and undesirables of all sorts to the offices, charges, and places of profit in the commonwealth. Thereby the finances are exhausted, and the faces of the poor ground to serve the benefit of the rich. Instead of one tyrant they suffer ten thousand. When there is too great generosity of this kind, wicked men, assassins, and disturbers of the peace of all kinds commit their evil deeds with impunity, for the good and liberal king cannot bring himself to refuse a petition of grace. The public good is sacrificed for the benefit of individuals, and the whole burden of the commonwealth falls on the poor.

One can verify what I say by many examples from both Greek and Latin history. But one need go no further afield than this country. Its condition was never more miserable than under a Charles the Simple. It was correspondingly great and prosperous in war and in peace under Francis I, who became most haughty and unapproachable as he grew older, so that none dared ask anything from him. In consequence lands, offices, and benefices all went to men of honour only. ...

A prince then must not be judged a tyrant because he is harsh and severe, provided always he keeps the laws of God and of nature. This point elucidated, let us consider whether it is right to make attempts upon the life of the tyrant.

The misuse of the term tyrant has misled many, and led to all sorts of unfortunate consequences. We have already said that the tyrant is one who on his own responsibility makes of himself a sovereign prince without election, hereditary claim, just conquest, or special divine commission. The opinions, and the laws of the ancient world condemned such to death. What is more, the ancients bestowed praise and honour in the form of titles of nobility, of chivalry, and statues and other marks of honour on the slayers of tyrants. They regarded them as the liberators of their fatherland, or as the 
inhabitants of Candia said, their motherland. They made no distinction between the virtuous prince and the evil and corrupt one. They did not think it proper that any man living should seize sovereign power, and make himself master over those who had been his equals and companions under any pretence of virtue and justice that he could allege. What is more, according to the civil law, anyone who assumed the authority reserved to the sovereign merited death. Wherefore if the subject tries to seize the government from the hands of his king by any means whatsoever -- and the same principle applies in popular states and in aristocracies -- he is worthy of death. It would seem then that our question is answered.

The Greeks and the Romans were at variance however as to what form the proceedings should take, whether by the operation of the law, or the act of an individual. The Lex Valeria, published at the instance of Publius Valerius Publicola, permitted homicide if one could make out a reasonable case for supposing that the dead man had indeed aspired to sovereign power. It was based on the argument that it was better to have resort to violence than to risk the destruction of both law and government in an anxiety to maintain the rule of law. If one insisted on a legal process, it was unlikely that such could be effected before the would-be tyrant had actually seized power, and once he had done so, it would be impossible to accomplish anything against one in control of all the organized forces in the commonwealth. On the other hand Solon legislated in the opposite sense, by expressly forbidding the resort to violence, and the assassination of the aspirant to power, until he had been brought to justice and condemned by due process of law. This seems more equitable than the Lex Valeria, for many good citizens and men of note have been murdered by their private enemies under the pretence that they were aiming at tyranny. After all, one can in such a case always regularize the situation by a retrospective trial after the fact. But it seems to me that both these principles can be accepted if one applies the law of Solon in the case where the prospective tyrant has not as yet got any armed forces under his control, and the Lex Valeria when the tyrant has come into the open and seized the citadel and its garrison. ...

But the real problem we have to consider is whether the legitimate ruler who has succeeded to power by election, hereditary right, just conquest, or divine commission, and then abandons himself to cruel exactions and every 
sort of wicked oppression can be killed, for this is the sort of man one generally means when one uses the word 'tyrant'. Many of the jurists and theologians who have considered the question have concluded that it is justifiable to kill the tyrant and without distinction. Indeed some have used the mutually exclusive terms 'tyrant-king'. This doctrine has been the ruin of many great and nourishing monarchies.

Before this question can be resolved, one must make a distinction between the prince who is an absolute sovereign, and the one who is not, and between the position in relation to him of the subject and the foreigner. For just as it is right and proper for anyone to take forcible action to defend the honour and life of those who are oppressed unjustly when the law offers no remedy, so it is highly honourable, and befitting a prince, to take up arms in defence of a whole people unjustly oppressed by a cruel tyrant. Such a one was Hercules when he went about the world destroying monsters of tyranny everywhere. For these exploits he was deified. Such also were Dion, Timoleon, and other generous princes who earned the title of scourge of tyrants ... In such a case there is no doubt that a virtuous prince can proceed against a tyrant either by force of arms, diplomatic intervention, or process of law. If he takes the tyrant captive, it is more to his honour to punish him as a murderer, a parricide, or a robber than to allow him the benefit of the law of nations.

But when it comes to the question of the conduct befitting a subject, one must distinguish between the sovereign prince and one who is not so. If he is not sovereign, sovereignty must lie with the people or with the magnates. In such cases one is justified in taking legal proceedings against him, if this is practicable, or in resorting to force and violence if there is no other way of bringing him to reason. Action of the first sort was taken by the Roman Senate against Nero, and of the second against Maximian, for the Roman Emperors were only the first magistrates of the Republic, sovereignty remaining in the people and the Senate ... A parallel case is the Empire of Germany. It is an aristocratic principality, in which the Emperor is only the first magistrate. The power and majesty of the Empire is vested in the Diet, and the Diet deposed the Emperor Adolf in 1296, and again in 1400 the Emperor Wenceslas, in each case by due process of law, for it had jurisdiction over them.... 
But if the prince is an absolute sovereign, as are the true kings of France, Spain, England, Scotland, Ethiopia, Turkey, Persia, and Muscovy, whose authority is unquestionably their own, and not shared with any of their subjects, then it is in no circumstances permissible either by any of their subjects in particular, or all in general, to attempt anything against the life and honour of their king, either by process of law or force of arms, even though he has committed all the evil, impious, and cruel deeds imaginable. No process of law is possible, for the subject has no jurisdiction over his prince, for all power and authority to command derives from him, he can revoke the commissions of all magistrates whatsoever, and his mere presence suspends the powers of all magistrates, corporations, colleges, estates, and communities. And if it is not allowable for the subject to pass judgement on his prince, the vassal on his lord, the servant on his master, that is to say proceed judicially against them, how much less is it allowable to proceed by force of arms. It is not a question of whether the subject has the means to do so, but whether it is lawful or within the competence of the subject to do so.

Not only is the subject guilty of high treason who kills his prince, but so also is he who has merely attempted it, counselled it, wished it or even considered it... We read that the most holy doctors that the Jews ever knew, those who were known as the Essenes or experts in the law of God, held that sovereign princes, of whatever character, should be regarded by their subjects as sacred and inviolable, and given of God. One cannot doubt that David, king and prophet, was informed by the spirit of God if ever man was, having always before his eyes the law of God. It was he who said, 'slander not the prince, nor speak evil of the magistrate'. Nothing is more insisted on in Holy Writ than the wickedness of compassing the death of the prince, or any responsible magistrate, or even making any attempt against their life or honour, even though, adds the Scripture, they be evil men.

If then the man who merely slanders the magistrates commits high treason by both divine and positive law, what punishment is sufficient for the man who attempts their lives? The law of God is much more precise on this point than are positive laws. Under the Lex Julia it is high treason to counsel the death of the magistrate or public official. But the law of God forbids any sort of detraction of the magistrate. 
It would be waste of time to meet point by point the trivial arguments of those who maintain the opposite view. One does not argue with the man who doubts if there is a God, one merely subjects him to the merited penalties of the law. They should be treated in the same way who have called in question a principle so obvious, and have maintained in print that the subject can justly take up arms against a tyrannical prince, and compass his death by any means in their power. Albeit, some of the most undoubted scholars among theologians[9] have denied that it is ever justifiable to kill or even resist a sovereign prince, unless by a special and indubitable commission from God. We have an example of such a one in Jehu, who was chosen of God, and anointed king by the Prophet with the express command to bring about the destruction of the race of Ahab. He was a subject, and never attempted anything against his prince, despite the latter's many cruelties, exactions and massacres of prophets, until he had received an express command from God through the mouth of the Prophet. ...

But one must not use these occasions of special divine commission to justify in general the conspiracies and insurrections of rebellious subjects against their sovereign lords... I cannot find a better analogy than the relationship between a father and his son. The law of God declares that the son who defies his father or mother should be put to death. If the father is a murderer, a thief, the betrayer of his country, incestuous, a parricide, a blasphemer or an atheist, though all the punishments imaginable would not be sufficient penalty for him, it is not for his son to play the executioner. But the person of one's native ruler is even more sacred, and should be regarded as more inviolable even than that of one's father, for he is ordained and set over his subjects by God.

I conclude then that the subject is never justified in any circumstances in attempting anything against his sovereign prince, however evil and tyrannical he may be. It is however permissible to fail to obey him in any commands contrary to the law of God and of nature, but one must then seek refuge in flight, go into hiding or suffer death rather than attempt anything against his life or his honour. What a great number of tyrants would be discovered if one might kill them. The prince who imposed heavy taxes would be one in the eyes of the vulgar. The man who ruled contrary to the wishes of the people would be one in Aristotle's eyes. The man who kept a body-guard for his protection and the man who executed those who conspired 
against his life would also be tyrants. What security could virtuous princes enjoy? I do not wish to deny to neighbouring princes the right to pursue tyrants by force of arms. I only wish to deny it to the subject. ...

\section{Concerning the Aristocratic State [CHAPTER VI]}

ARISTOCRACY is that form of commonwealth in which the minority of the citizens have sovereign authority over the rest considered collectively, and over every citizen considered individually. It is therefore the opposite of the popular state, for there the majority of the citizens command the remainder considered collectively. But they resemble one another in this, that in either commonwealth the governing body has authority over the whole body of citizens only in their individual capacity, and not considered as a corporate whole. The monarchical commonwealth excels the other two in this respect, since the authority of the king extends over all, both in their aspect of a corporate whole, and in their aspect of a collection of individuals.

Just as monarchy can be royal, despotic or tyrannical, so aristocracy can be legitimate, despotic or factious. In ancient times the latter was called oligarchy, or the rule of a small handful of magnates. Such were the thirty rulers of Athens denounced by Thrasybulus, who were known as the Thirty Tyrants. Such also was the Decemvirate appointed to reform the laws and customs of the Romans. By force and violence, and aided by a faction of the citizens, they seized the government. Such practices explain why the ancients always used the term oligarchy in a bad sense, and aristocracy in a good, since they confined the latter to the rule of good and honest men.

But we have already shown that commonwealths cannot be classified according to the vices and virtues of their rulers when considering the form of the state. Such classification only applies to the form of the government. Moreover it is difficult, if not impossible, to erect a government which consists solely of honest men. Casting lots is no way of securing their selection, and election by their fellows is hardly more likely to do so. These are the two methods commonly used, though a third method got by combining the other two is sometimes employed. One must suppose all the electors to be honest men themselves if one is to be sure that honest men will be elected. Rogues choose others like themselves and in such a case 
honest men have not the effrontery to put themselves forward... In any case what guarantee can there ever be that the electors will not choose some relative, rather, son, brother, or even some friend, rather than a stranger however deserving he may be? This is why there are not now, and perhaps never were, any such states as pure aristocracies.

Therefore whether the government is in the hands of men of birth, of merit, of wealth, a military caste, the poor, the workers, or a set of scoundrels, provided it is a minority that rules, that state I call an aristocracy.

When I say the minority of the citizens, I mean the greater number of that minority when assembled together as a corporate body. If there are ten thousand citizens of whom one hundred gentlemen only share sovereign power, if sixty of those are in agreement, they have an absolute right of command over the remaining nine thousand nine hundred citizens in general, who have no part in government, as well as those other forty who have. In other words the sixty have sovereign authority over all the ten thousand citizens considered as individuals, just as much as the hundred considered as a corporate body would have had, had they been in agreement. Neither the size of the state nor the proportion of the minority ruling class to the rest is significant. If there are a hundred thousand citizens and ten thousand of them participate in sovereignty the state is no less an aristocracy than if there are ten thousand citizens of whom one thousand govern the rest. In each case a tenth part governs. The same is true if it is only a hundredth or a thousandth part. But the smaller the governing minority, the stronger and more secure the state.

The state of Germany needs rather more careful examination in this connection. Even many well-informed persons think that it is a monarchy. I have said something about this already, but it is here convenient to show with more preciseness that it is an aristocracy. From the time of Charlemagne to that of Henry the Fowler it was a pure monarchy by right of succession in the line of Charlemagne. After Henry the Fowler, the monarchy long continued as an elective one, till the seven Electors gradually established their own sovereignty, leaving nothing to the Emperor but the symbols of power. All real power was in the seven Electors, the three hundred or so Princes of the Empire, and the representatives of the Imperial Free Cities. We have defined the aristocratic state as one in which the minority of citizens command the rest considered collectively, and each and 
all severally. Can it be shown then that the Imperial Diet, made up of three or four hundred men, has sovereign power to the exclusion of the claims of the Emperor on the one hand, and the Princes and Cities individually on the other, to make law for all the subjects of the Empire, to declare war and conclude peace, impose taxes and imposts, appoint judges ordinary and extraordinary with jurisdiction over the possessions, the honours, the life of the Emperor, the Princes and the Imperial Cities -- for such are the authentic marks of sovereignty -- ? If this is the case, and it is certain that it is, then it cannot be denied that the state of Germany is a true aristocracy.

That what I say is true is evident from the fact that sovereign commands are issued in the form of rescripts and decrees of the Diet. Decrees are published by the authority of a body consisting of the seven Electors, who have a third voice, by the other Princes of the Empire who hardly number three hundred in all, who have another third voice, and by the deputies of the Imperial Cities to the number of about seventy, who have the remaining third voice. Together they have full authority to enact or retract, confirm or reject, whatsoever is proposed. There is nothing peculiar about this constitution to distinguish it from any other aristocracy, save that the Electors have one vote, the Princes a second, and the Cities a third, so that if the seven Electors and the deputies, or the deputies and the Princes, or the Electors and the Princes are in agreement, the measure becomes law....

There are others who think that the Princes and the Imperial Cities severally enjoy sovereign power, and that the Imperial Diet has no more power than the assemblies of the Swiss Confederation. There is, nevertheless, a great difference between them. Each Canton is sovereign, without subjection to the laws and commands of the others; they have no obligation to one another other than those specified under the terms of their defensive and offensive alliances. But the Empire of Germany is united in its Diet. The Diet can place Cities and Princes under the Imperial ban, and depose Emperors from their estate by the sovereign authority inhering in it, as on the occasion of the rejection of Adolf, and of Wenceslas son of Charles IV, and many others. Moreover the Diet regularly publishes decrees and ordinances binding on all the subjects of the Empire, both in general and in particular. 
What is more, the ten Circles, or circuits of the Empire, hold their separate diets to formulate their particular petitions, grievances, and complaints, to the Imperial Diet, in order that it may issue its decisions in the matter. Again, the Electoral Princes, after the coronation of the Emperor, take an oath of allegiance to the Empire, not to the Emperor, though they actually swear the oath between his hands... Finally, the Emperor as head unites the Empire even more closely in a single commonwealth than if it was only united in the Diet. I have said 'as head of the Empire', or captain in chief, but I do not mean by that as sovereign lord, such as many think he is. For whereas kings and monarchs make princes, the Emperor on the contrary is elected and made such by the Princes....

In the face of these facts how can anyone persist in the opinion that the Emperor is a sovereign, and the Empire a monarchy united in a single person?... It must also be conceded that there is no Prince or Imperial City which has sovereign authority. Each is a member of the Empire, governing the state under his authority subject to the laws and ordinances of the Empire ... It is only when the Empire is divided into hostile factions, as has so often happened, and the Princes banded together the one against the other, that the communal governments of the towns, and the subordinate jurisdictions of the Princes, are converted into a number of separate aristocracies and monarchies. Each member of the Empire then constitutes itself a particular sovereign state. ...

A well-ordered aristocracy is extraordinarily satisfactory as a form of government. A corrupted one is correspondingly pernicious, for instead of a single tyrant there are a multitude. This is most likely to happen, and often does when the nobles band together against the common people. In ancient times, when the nobles were admitted to power in aristocratic states, they took an oath that they would be from that time forth the sworn enemies of the people. This was the ruin of aristocracies. Let us now turn to popular states.

\section{Concerning Popular States [CHAPTER VII]}

A POPULAR state is that form of commonwealth in which the majority of the people have collectively sovereign authority over the rest considered collectively, and over each several member considered individually. It is 
the necessary mark of the popular state that the greater part of the people have authority to command not only each particular citizen as such, but the minority of the people as a body. If there are thirty-five clans, or groupings of the people, as in Rome, eighteen of them have sovereign power over the other seventeen and can bind them by the laws they make. This was the case when Marcus Octavius was deprived of the tribunate at the instance of his colleague, Tiberius Gracchus....

When I say that the majority of the people are invested with sovereign power in a popular state, this holds good when votes are counted by head as in Venice, Ragusa, Lucca, Genoa, and practically all aristocratic republics. But if one counts votes by clans, or districts, or communities, it suffices that the majority of clans, districts, or communities as the case may be, are agreed, even if the majority so determined includes only a minority of the actual number of citizens. This was practically always the arrangement in the popular republics of the ancient world....

These arrangements provide the answer to those who say that there cannot be, never was, nor ever could be a truly popular state where the whole assembled people make law, appoint to office, and exercise all the prerogatives of sovereignty, seeing that the greater number are generally absent, and it is only a small group that actually makes the law. But it suffices if the greater number of clans are agreed, even if there are only fifty people in one and a thousand in another, provided that the right of recording his vote is secured to each individual, should he wish to be present. But in order to prevent a faction securing the ascendancy by intriguing with the most influential members of the various clans, it was customary when some law of importance was under discussion to add some clause, such as that the law about to be published could not be rescinded save by the assembly of the whole people, six thousand citizens at least being present. One finds many examples in Demosthenes, and in the Lives of the Ten Orators, and Plutarch adds that a sentence of ostracism could not take effect if less than six thousand citizens consented. A similar safeguard is provided by the ordinances of Venice, whereby in all matters of consequence, or touching the administration of justice, it is provided that there shall be no amendment of the ordinances of the city by the Great Council unless there are at least a thousand Venetian citizens present, and of these four-fifths, or five-sixths, as the case may be, are in agreement. Only when such conditions 
are satisfied can a law be imposed on the rest of the community. This law is the same in principle as the law governing the procedure of guilds and corporate associations, by which two-thirds of the members are required to be present in session, and the majority of this two-thirds in agreement, to make a regulation binding on the rest. ...

We have said above that the state can be a pure monarchy and its government popular, as happens when the prince distributes lands, offices, and rewards indifferently to rich and poor, noble and commoner without exception of persons. Or a state can be a monarchy governed aristocratically if the princ e confines his gifts of lands and offices to a few nobles, or a handful of rich men, or his personal favourites. On the other hand if the majority of the citizens share sovereign power, but only bestow the responsible offices, honours, and prerogatives on the nobles, as was done in Rome till the publication of the Lex Canuleia, the state will be a popular one, but the government aristocratic. If government is in the hands of the nobles, or the wealthy, but they open offices and privileges to poor and simple citizens, as well as to the rich, without favour shown, the state is an aristocracy governed democratically. If the people have sovereign power and give lands and political privileges to all without respect of persons, or if all offices and benefices are filled by lot, the state is not only a popular state, but governed as such... In the same way, if the nobles or the wealthy alone govern the state, and reserve lands and honourable charges for their own class, one can say not only that the state is an aristocracy, but also that it is governed aristocratically. Such is the case of Venice.

It may be objected that I am alone in making such distinctions, and that none of the ancients, still less contemporary writers on politics, have developed such views. This I don't deny. But it seems to me necessary to make such distinctions if one would understand the true character of every type of commonwealth, and avoid falling into a maze of errors, such as did Aristotle. He confused the popular and the aristocratic state, and vice versa, against common opinion and even common sense.

But one can never build a secure superstructure on ill-founded principles. Such confusions lead to the ill-formed opinion of those who think one can have a commonwealth compounded of all three basic types which we have rejected as impossible. We consider it indisputable that the form of the 
commonwealth is always simple, even though the government may be of a contrary type, as a monarchy is clearly contrary to a popular state in principle, yet nevertheless sovereign majesty may reside in a prince who governs his realm as if it were a popular state. But this is not a commixture of monarchy and democracy, which are mutually incompatible. It is a monarchy with a popular government, and this is the most secure kind of monarchy there is. The same may be said of the state which is an aristocracy whose government is popular. It is much more secure than if its government were aristocratic. ...

Popular government can admit of degrees of more and less, as can be seen in the case of the Swiss Republics. Uri, Schwyz, Unterwalden, Zug, Glarus, and Appenzel are governed by sovereign communes, and there is not a fortified town in any of the five, save only Zug. The other nine Cantons and Geneva are governed by a council of magnates, as I learn from M. de Bassefontaine, Bishop of Limoges, who has long discharged the duties of ambassador there in the most unexceptionable and honourable manner. Even the Bernese, whose senate is composed of craftsmen, choose the Advocate from the most noble and ancient families. It is in consequence more stable than the others. The three leagues of the Grisons, which are the most popular in organization, are much the most disturbed, as foreign ambassadors have always found.

For the true nature of a people is to seek unbridled liberty without restraint. They would make all equal in goods, honours, punishments, and rewards, without any respect whatsoever for noble birth, education, or virtue. As Plutarch said in his Symposia, they want everything decided by lot or by divination, without respect of persons. If the nobles or the wealthy show any signs of wishing to make their influence felt, they hasten to massacre or banish them, and divide their confiscated property among the poor. This happened at the foundation of the free Swiss republics, after the battle of Sempach.[10] The noblesse were all but exterminated, and the remnant compelled to renounce their title to nobility, yet nevertheless they were ejected from their lands and offices, save in Zurich and Berne....

On the other hand nobles and wealthy men generally look at things in quite a different way. They think that those who are distinguished by birth, wealth, education, or experience should be more esteemed, deferred to, and honoured than the rest, and that all honourable charges should be reserved 
to such men. They therefore take pains to exclude the poor from any share in the management of affairs of state. It is impossible to compound two such diametrically opposed attitudes, in spite of Solon's claim to have made laws which were equal alike for rich and poor, noble and simple. For the rich understand by equality, proportional equality, the poor, absolute equality. We shall explain in the proper place what is meant by these terms, and the advantages and disadvantages of each type of commonwealth. At the moment it suffices to have defined and described them.

1. In his work on Venice, Della Republica e Magistrati di Venetia, 1563.

2. In his Discorsi supra la prima deca di Tito Livio, first published 1532, and in a collected edition, 1550 .

3. Historian of Venice. His Rerum Venetarum ah urbe condita ad Marcum Barbaricum Libri XXXIII was published in 1487.

4. There is a marginal reference in the Latin version made by Bodin in 1586 to Du Haillan. He wrote a book De I'estat et succes des affaires lie France, published in 1570, which Bodin very largely drew on for his account of the French monarchy.

5. This belief that lordship began with Nimrod, and was rooted in iniquity, was a tradition enshrined in the canon law. Gratian ascribes the founding of societies of men regulated by laws to Cain, and their refoundation after the flood, to Nimrod.

6. Its author was Sigismund, Baron d'Herberstein. His Rerum Muscoviticarum Commentarii was published in 1549 and several times subsequently.

7. Historiarum sui temporis Libri XLV, Lib. xviii. 1530.

8. Succeeded in 1537 . He founded a stable dynasty and so put an end to the chronic instability of Florentine politics.

9. There is a marginal reference to Luther and Calvin. 
10. 1377. It was fought against their Hapsburg overlords, and the victory laid the foundations of the effective independence of the Forest Cantons.

\section{BOOK III[1]}

The Council [CHAPTER I]

A COUNCIL is the legal assembly of the councillors of state, whose function it is to advise the sovereign in the commonwealth ... Not that a council is necessary to the continued existence of the commonwealth. A prince may be so wise and experienced that he is his own best councillor, and he may dispense with advice from anyone else, whether friend or foreigner. Antigonus, King of Asia, Louis XI of France, and the Emperor Charles V were of this sort. They followed the example of Julius Caesar, who confided in no one about his plans, his expeditions, or even the day he had fixed on for battle. Yet all these men accomplished great things, though assailed by many and powerful enemies. They were the more dreaded in that their designs being unknown, they were put into execution before the enemy had wind of them. Their subjects were kept in good order, ready to execute the commands of their prince the moment he lifted a finger. The state therefore flourished like a healthy body in which all the members obey the head without having any part in its deliberations.

But there are some who have doubted, without much reason to my mind, whether it is better to have a foolish prince who is well-advised or a wise man who eschews good counsel, though those who claimed to be wisest rejected the alternatives as unreal. They argued that in the first place, if the prince is as wise as supposed, he has no great need of counsel, and without it he enjoys the advantage of keeping secret his designs, which being made public would be about as effective as an exploded mine. In fact wise princes order things so well that they habitually talk most about what they are least concerned to accomplish. On the other hand how is it possible for a stupid prince to secure good counsel, when the choice of a council rests with him in the first place, and the ability to recognize worth and act upon good advice is itself a 
mark of knowledge of men and of affairs?

But since the gift of wisdom is vouchsafed only to the very few, and we are bound in obedience to all such princes as it pleases God to bestow upon us, the best thing we can hope for is that he may have wise counsel. It is much less dangerous to have a bad prince who is well-advised than a good one who is ill-advised, as the Emperor Alexander observed. The prince should be guided by the advice of his council in small matters as well as great. Nothing gives more authority to the laws, or to the commands of the prince, the people, or the ruling class as the case may be, than the knowledge that they proceed from good counsel ... Where subjects see edicts and mandates is sued contrary to the advice of the council, they tend to treat them with contempt. From contempt of the law springs contempt of the magistrates. Open rebellion against the prince follows, and the whole commonwealth is brought to ruin. Hieronymus, King of Sicily, lost his throne, and was put to a cruel death together with all his family for having despised his council and refused to consult them... For this reason Louis XI caused his son Charles to be brought up practically without education, as Philippe de Comines's History shows, to force him to be guided by his council. Louis well knew that those who have a good conceit of themselves rely entirely on their own judgement, a failing which had brought Louis himself to the brink of destruction, as he afterwards confessed....

The council must necessarily be small in numbers in view of the rare qualities requisite in a councillor. It is true however that in popular and aristocratic commonwealths it has been necessary, in order to avoid disturbances, to appease the appetites of ambitious persons. In Athens, for example, by the ordinance of Solon, four hundred councillors were chosen by lot every fourth year. Later the number was increased ... But it is not really desirable that the size of the council should be determined according to the number of citizens, nor to satisfy the vanity of ignorant persons, still less to draw profit from such appointments. It should be chosen solely with regard to the virtue and wisdom of those who merit such a responsibility. If it is not possible otherw ise to appease the ambition of those who enjoy political power in aristocracies and democracies, and political necessity demands the opening of the council to the multitude, then let eligibility be 
confined to those who have held responsible offices. ...

But one should not take such action unless there is no other way of avoiding popular disturbances. Apart from the obvious danger of the publicity which attends the communication of important matters to so many people, opportunity is given to the factions to create disorder ... It is moreover very difficult to assemble a very large council in the required numbers and to secure any agreement among them, and meanwhile the state is in great danger, and the opportunity for successful action is lost. ...

A council is instituted to advise those who exercise sovereign authority in the commonwealth. I say 'advise' because the council in any well-ordered commonwealth should have no power of action, nor of issuing commands, nor of putting into execution the policies it advises. All such matters should be referred to those who exercise sovereign authority. It is of course true that there are commonwealths in which such powers are in fact exercised by the council. But I hold that in a well-ordered commonwealth such powers ought not to be permitted. They cannot be admitted without a considerable diminution of sovereignty, more dangerous to a monarchy even than to an aristocracy or popular state. The majesty of a prince is best displayed when he can, and his prudence when he knows how to, weigh and appraise the advice of his council, and decide according to the opinion of the wiser part, rather than the opinion of the greater part. It may be objected that it is not fitting that high courts and officers of state should have power to command, and issue commissions in their own name, while the council, which judges the differences between them, should be denied such powers. But the answer is that high courts and officers of state have power to command in virtue of their institution, and their powers are delimited and defined in the edicts establishing their offices. There was never a council in any well-ordered commonwealth which had power to command by the terms of its institution. Therefore neither in Spain, England, or France do you find that the council is legally instituted as a college, with its powers defined by law in some statute, as is necessarily the case for the institution of all magistracies, as we shall show. If it is objected that the council has the power to revise the judgements of high courts and supreme magistrates, and that one cannot argue therefore that 
it has no power of action, I would point out that the privy council in doing this is not acting independently, but under a royal commission, as judges extraordinary in a matter of justice. ...

It may be questioned whether the council in a popular or aristocratic state has not more power than under a monarchy, having regard to the difference there is between one ruler and many, a prince and the people, a king and a multitude of men. We read of the Romans, whose republic was admittedly the most nourishing and well-ordered that has ever existed, that the Senate had the power to manage the finances, which is one of the undoubted attributes of sovereignty. It could also appoint lieutenants and governors of provinces, award triumphs, and consider matters of religion ... Notwithstanding all this, I still say that the council in a democracy or an aristocracy should have no function but to deliberate and advise. Power to act ought to be reserved to those who have sovereign authority. Whatever can be said about the powers of the Roman Senate, they were only a matter of dignity, authority, and counsel, and not of authority. The Roman people could, whenever it saw fit, confirm or reject the decrees of the Senate. The Senate had no power of command, or even of executing its own orders... If then in a popular state the council has no ordinary power of commanding, save on sufferance, still less has it such powers in an aristocracy or a monarchy. In a monarchy especially, the king is much more jealous of invasions of his authority than are a people.

The reason why the council in a commonwealth ought not to have power to give effect to its own advice is that, if it had, sovereignty would he in the council, and the councillors would rule, having power to manage the affairs of state and order all things according to their own good pleasure. This could not be without the diminution or even destruction of the sovereign majesty, though sovereignty is of so high and sacred a character that no subject of whatever degree can have any part in it, great or small. For this reason the Great Council at Venice, which in that state is the sovereign power, forbad the Ten, who were extending their activities beyond the limits prescribed, upon pain of treason to take any action, or even to dictate letters which they call definitive, without having recourse to the Signory, pending the assembly of the Great Council. ... 
Officers of State and Holders of Commissions [CHAPTERS II AND III]

AN officer is the public person who has an ordinary charge defined by law. The holder of a commission is the public person who has an extraordinary charge defined in the terms of the commission. In each case there are two grades of persons, those who have power to issue orders, or magistrates, and those subordinate officials who can only take cognizance of the facts, or execute orders. There are other sorts of public persons who are neither officers nor holders of commissions, such as popes, bishops, and ministers of religion generally. They are holders of benefices rather than offices. This class of public persons must on no account be confused with the former, for their business is with divine matters, whereas officers and holders of commissions are only concerned with human affairs. Moreover their functions are not determined by edicts, or any laws of the state, as are those of officers.

Let us consider the accuracy of these definitions before entering into a more particular discussion of the various categories of persons. Neither the jurists, nor anyone else who has written about politics, has adequately defined, or even described, what an office is, and what the holder of a commission or a magistrate is. But it is very necessary to have a clear understanding of their functions, seeing that they form one of the principal parts of the commonwealth, for it cannot subsist without them....

The description of an officer as a public person is not disputed, since the difference between an officer and a private individual is simply that one has a public charge and the other has not. I have said that he has an ordinary charge to distinguish him from the holder of a commission. The latter has an extraordinary public charge occasioned by some particular circumstance. Such were in ancient times dictators, and members of commissions set up by the people, on the request of the magistrates, to inform about crimes. I have said that ordinary charges are defined by edict, for there is no way of creating an office to which a specific function is attached save by edict or explicit enactment. This principle was always observed in the ancient commonwealths of the Greeks and the Romans, and is even more strictly followed today. To this 
end princes are in the habit of requiring edicts establishing the humblest offices to be published both in high courts and inferior courts... An office, once created, is set up in perpetuity, even though the holder of it is only appointed for one year at a time. For whatever the term prescribed for the holder of it, an office remains, once it is established by law, until another law to the contrary effect abolishes it... I have said that it is an ordinary charge set up by law because the mandates of the Roman people, setting up commissions with extraordinary charges, were also given the name of laws, and the duties, the term, and the scope were determined by them. The commissions under which the Roman people from time to time set up a dictatorship are an example. The Lex Gabinia gave Pompey supreme command within the shores, and over the coast towns of the Mediterranean for the term of five years for the purpose of putting an end to piracy....

It is of the very nature of commissions that there are no conditions relating to time, place, and function included in their terms of appointment, which cannot be revoked at will. In point of fact a time limit is seldom set in monarchical states. But in popular states and aristocracies there generally is for fear of the commissioners acquiring sufficient power to destroy liberty. This happened with the Decemvirate in Rome ... The Florentines suffered in the same way. They set up a commission of ten, and gave them absolute power for four or five years to order the Republic, all other magistracies being suspended. But no term within which the reordering of the Republic was to be effected was fixed. This gave an opportunity to a clique to monopolize the government indefinitely though they went through the form of resigning.[2] The suspension of all the ordinary magistracies gives too much power to a commission, and cannot be done without grave danger to the commonwealth, save in a monarchy....

The distinction between an office and a commission can briefly be expressed in this way, that an office is like a lease which the proprietor cannot terminate till its term is expired; a commission is held at will, a precarious loan that the lender can call in any time he chooses ... A commission is terminated by the death of the grantor, or his express revocation, or when the holder succeeds to any office which makes him the equal of the grantor ... This is not the case with 
officers. Their offices are not terminated by the death of the prince, though they hold them on sufferance, and are, as it were, suspended till they receive letters of reappointment, or are confirmed in their offices by the new prince. For this reason, on the death of Louis XI, the Parlement of Paris, in obedience to a judgement of the court given in October 1381, ruled that all officials should remain at their posts till the will of the new king should be known....

There is another difference between an officer and a commissioner besides the fact that one has an ordinary and the other an extraordinary charge, and that is that the authority of an officer is the more extensive and takes precedence. For this reason edicts and ordinances leave much to the good faith and discretion of the magistrates, so that they can apply and interpret the laws equitably, and take into consideration the circumstances of the case. But commissioners on the other hand are strictly bound by the precise terms of their commission, even in affairs of state. Ambassadors and envoys, appointed to negotiate between princes, cannot go a step beyond their instructions unless some clause is added (as is often the case with diplomatic charges) allowing them, when they see how matters stand, to adjust or abate the terms as prudence and discretion dictate. But this never extends to the principal clauses and concessions of treaties, but only to minor matters of less importance. ...

The magistrate is the officer in the commonwealth who has the power to command obedience. We must first however explain that the institution of commissioners is older than that of officers. It is certain that the earliest commonwealths were governed by the sovereign authority of the prince in person, without the assistance of laws. The word, the sign, the will of the prince was law. Princes gave charges in peace and in war to whomsoever they wished, and revoked these charges at their absolute good pleasure. Public servants depended directly on the plenary authority of the prince, and were not secured by either laws or customs. Josephus in his second book against Appion, wishing to prove the illustrious antiquity of the Hebrew race, and of its laws, points out that the word law does not appear in Homer at all. This supports the case for supposing that the earliest commonwealths only knew commissions, since an officer is necessarily established by an express 
law. This would seem to compromise the sovereign power of the prince. For this reason the kings and princes who have been most jealous of their authority have adopted the expedient of including in all letters of appointment an ancient clause, reminiscent of the original despotic monarchs, that the office is held 'during our good pleasure'. It is true that in France, though it was once strictly observed, it has no meaning in fact since the ordinance of Louis XI.[3] But in Spain, England, Denmark, Sweden, Germany, and Poland, and all the Italian states, it is still strictly observed. Secretaries never omit it, and its appearance is another argument in favour of supposing that all public charges were originally executed by commissioners.

There is as much confusion among writers on the subject between the terms magistrate and officer as there is between officers and holders of a commission. Every magistrate is an officer, but every officer is not a magistrate, but only those who have pow er to command obedience ... Public persons who have an ordinary charge defined by law, which does not carry with it power to command obedience, are simple officers, the kind of persons the last Emperors call officiales....

In every commonwealth there are three things to be observed about the appointment of officers and magistrates; who appoints, who is eligible for appointment, and the method of selection. In the first case, it is always the sovereign who appoints. Who is eligible is also determined by the sovereign, but as a general rule he keeps to the laws which he himself has made, fixing qualifications. This is more especially the case in aristocracies and popular states. In the one case magistrates are chosen from the nobles, or the wealthy, or those who are most experienced in the matters with which their office is concerned. In the other case they are open to all conditions of citizens. As to the method of selection, it can be either by election, by lot, or a combination of the two....

Magistrates can also be divided into three grades. The first are what might be called sovereign magistrates, because they owe obedience to none but the sovereign himself. The second are the intermediate magistrates who owe obedience to the sovereign magistrates, but themselves have subordinates under them. The third are those inferior 
magistrates who owe obedience to both ranks of superior magistrates, but themselves can only command private citizens. Let us consider them in order.

The Magistrate [CHAPTERS IV AND V]

AFTER the sovereign, the magistrate is the chief personage in the commonwealth, for upon him the sovereign devolves his authority and his power of commanding obedience. We must therefore consider what obedience is due from the magistrate to the prince, since this is his first duty. Unlike the sovereign who knows no superior, but sees all his subjects obedient to his power, or the private citizen who has no official right to use compulsion against anyone, the magistrate is many personages of different quality, bearing, appearance, and mode of action in one. To fulfil his role he must know how to obey his sovereign, defer to those magistrates who are his superiors, honour his equals, command those subject to him, defend the weak, hold fast against the strong, do justice to all. ...

But before one can properly consider the obedience due from the magistrate to his sovereign, one must consider the form that the commands of the sovereign can take. For the prince issues orders of various sorts. There are general and perpetual edicts, binding on all sorts and conditions of his subjects whatsoever; or there are laws relating to certain persons, or certain circumstances, by way of provision; there are grants of exemption in favour of a single person, or a small group of such; or there are grants of privilege which do not involve any suspension of the law; there are grants of offices and commissions; there are the orders that declare war, publish peace, raise the army, or equip a fleet; there are levies of taxes, aids, subsidies, new imposts, and loans; there are the despatches issued to ambassadors instructing them to felicitate or condole with foreign princes, and treat of marriages, alliances, and such like matters; there are letters of execution for the expediting of justice, the restitution of minors, the remission of sentences, or pardon of offences and such like matters ... All these various kinds of orders can be reduced to two types, mandates and letters of justice. ...[4] 
In letters of justice the prince leaves it to the discretion of the magistrate to whom the letters are addressed to act on them or not as his conscience and the demands of equity dictate. This is not the case with mandates, which leave nothing to the discretion of the executor, unless it be sometimes verification of the facts alone, but without any choice as to the execution of his instructions. It can therefore be said of letters of justice that though they proceed from the prince, they do not impose any command or compulsion on the magistrate to whom they are addressed. On the contrary, by the ordinance of Charles VII and Philip IV, judges are expressly forbidden to apply them if they are inequitable ... The question therefore as to how far the magistrate is bound to obey them does not arise.

Mandates on the other hand raise a difficulty, since they require the magistrate to enquire into the facts without giving him any discretionary power of action. What is he to do if, having informed himself of the facts, as directed, he sees that to act in the way commanded would involve a notable injustice? Sometimes princes accompany unjust mandates by particular letters close, praying the magistrate to execute them. In letters patent prayers are often accompanied by commands, 'We pray and at the same time command you that...' In acting thus, the prince derogates from his authority if the command is of public benefit, and from the law of God and of nature if it is unjust. A magistrate ought never to be entreated to do his duty, or dissuaded from doing a thing which is unjust and dishonest, as Cato said. Moreover command is incompatible with entreaty.

The difficulty may be settled in this way. If his instructions give him cognizance neither of the facts nor of the rights of the case, but simply require him to execute an order, he has no option but to obey, except the letters be notoriously null and void, or contrary to the laws of nature, such as was Pharaoh's and Agrippa's commands to slaughter the innocents, or in our own day those of the Marquis Albert to rob and despoil the poor.[5] If the subject of a particular lord or justice is not under any obligation to obey the lord or the magistrate who exceeds his jurisdiction and invades the sphere of another, even if the thing commanded be just and honourable, still less is the magistrate bound to obey orders from his prince which are unjust and dishonourable. In such 
a case the prince oversteps the sacred bounds of the laws of God and of nature. ...

If however the orders of the prince are not contrary to the divine and natural law, he must execute them, even if they are contrary to the law of nations, for the law of nations can be modified by the civil laws of any particular state, provided natural justice and equity to which the prince is bound is not infringed, but public or particular utility only is in question. Though we have stated that the prince ought to keep the oath which he has sworn, if he is constrained by oath, and even when not so, he ought to keep the laws of the commonwealth over which he is sovereign, one cannot conclude therefore that if the prince should fail in his duty in this or that respect, the magistrate need not obey him. It is not for the magistrate to take cognizance, or contravene in any particular the will of the prince in regard to positive laws, since the prince is free to disregard them. But if the magistrate is aware that the prince is setting aside a just and useful provision for one that is less so, he can delay execution of the edict or mandate till he has made representations. He can do this not once, but two or three times. But if, notwithstanding these remonstrances, the prince insists on obedience, then the magistrate must give it effect from the time of the original instruction if delay is dangerous. ...

It may be argued that a magistrate should refuse obedience to a mandate that he thinks is against natural justice, even if, in fact, it is not so. For the principles of what is called natural justice and natural reason are not so clear that there can be no uncertainty about them. The most famous jurists have disagreed about them, and the legal systems of different peoples run counter to one another, the laws of one rewarding acts which are punishable under another. One can find any number of examples, and it would take an infinity of time to make a full list. But I would answer that one should never do anything that one thought even doubtfully just, and much less anything that one was persuaded was of its very nature unjust, even though the prince commanded it. But if it is a question simply of justice according to the law, the magistrate ought to execute the sovereign's commands, even though he considers them legally inequitable. Therefore in order to secure that those rules which have been resolved upon as laws shall not be the subject of dispute, 
magistrates in all commonwealths are required to take an oath to observe the laws and ordinances....

There are those who question whether a magistrate ought not to resign his office rather than act upon an edict, a commission, or a mandate which he thinks against justice and natural reason, even if, when challenged, the majority, contrary to the opinion of the rest, consider it to be just. Rational and sound principles, it is argued, imply a well-regulated mind, and that is only found in those few who have wisdom and understanding. But $\mathrm{I}$ hold that in such cases it is not permissible for the magistrate to resign his office, unless allowed to do so by the sovereign. He is bound to obey the orders of his prince if, the justice of those orders having been called in question, the majority of the magistrates responsible for their execution are agreed on accepting them. Otherwise, if a magistrate were allowed to resign his charge rather than accept an edict approved by the others a dangerous, precedent would be created for all subjects to question and disobey the edicts of the prince, and it would be open to everyone in a place of trust to expose the commonwealth to danger, and leave it like a ship without a navigator in a tempest, on some pretext of justice which probably is the idle fancy of an eccentric, or of one merely concerned to think differently from the rest. One of the most laudable ordinances of Louis XII was that which required that when the Judges were divided by two or three opinions, the minority must range themselves on the side of the larger party, or parties, in order that a decision might be reached. There was some difficulty in getting the edict registered, for it seemed strange to the court that the consciences of Judges should be constrained in matters committed to their prudence and integrity. Nevertheless having considered the frequent difficulties that arose from the variety of opinions among the Judges, to the prejudice of justice and prevention of any delivering of judgement, the court verified an ordinance, which after some passage of time was recognized to be both just and useful. ...

There is however a great difference between edicts and ordinances which have become law, and those which are being submitted for registration. All magistrates, on their appointment, swear to keep the laws, and if they do otherwise, in addition to the legal penalties they incur, they 
suffer dishonour as perjured. But magistrates are free to examine edicts and mandates which are not already law, but submitted for registration, and can remonstrate to the prince before proceeding to verify them, as I have explained above. They can do this when the interest of a private citizen only is at stake. Even more can they do so when it is a question of profit or loss to the whole commonwealth. It is of much greater service to the commonwealth, and much more befitting the dignity of a magistrate, to resign his office than to help to establish an iniquitous law.[6] ... The constancy and firmness of magistrates has often enough saved the honour of the prince and preserved the dignity of the commonwealth.

The mandates which are of greatest consequence to the public welfare are those granting privileges, dispensations, exemptions, and immunities. The magistrate ought therefore to be particularly vigilant in examining them, especially in popular states, where inequalities caused by grants of privileges bring about popular disturbances which often lead to the downfall of the commonwealth ... There is no need to enter into a discussion of the vexed question of privilege at this point. It is sufficient in passing to warn the magistrate to pay close attention to letters granting privileges, and examine carefully the claims of the person to whom the prince is making the grant. It is well known that often enough the prince has never set eyes on those who extract privileges from him. There is no ruse or stratagem which has not been tried in order to defeat the laws and abuse the goodwill of the prince and his officers. ...

Once the magistrate has remonstrated with the prince about the truth of the facts and the import of his orders, he is quit of his duty, and must obey if he is nevertheless required to. Otherwise the majesty of a sovereign prince would be a sham and at the mercy of the magistrates. But what is to be feared is not so much that the sovereign majesty of the prince will be diminished, as that first the lesser magistrates, and then the people as a whole, will be encouraged to disobey the prince. This leads inevitably to the downfall of the state. If anyone says to me that the prince ought never to command anything which is iniquitous, I agree, and would add, he ought never, if possible, to command anything which might be considered reprehensible or open to criticism. If he 
knows that the opinion of the magistracy is against him in any matter, he should avoid putting constraint upon its members. For in such circumstances an ignorant people is moved to contempt for the laws, and to the habit of disobedience, seeing them established only by compulsion.

But supposing the prince does indeed fail in his duty, and command something which is contrary to the public good and the justice of the laws, but not contrary to the law of God and of nature, what ought the magistrate to do? If the humblest magistrate ought to be obeyed even when he commands something inequitable, how much more should the sovereign prince be obeyed, since all magistracies derive from him? The laws, founded on the experience of wise men, repeat over and over again that one should obey the magistrate whether he commands what is just or unjust... Have we not all seen subjects arm themselves against their sovereign prince, following the example of disobedient magistrates who have refused to register or execute the laws? The cry is always raised, this edict is damaging to the common good, and we ought not to, and cannot register it. It is good that a protest should be made. But should the will of the prince remain firm and immutable, is one justified in hazarding the safety of the state? Should one allow oneself to be compelled? Is it not better to resign one's office? On the other hand is there anything more dangerous or more wicked than disobedience and contempt of the subject for his sovereign? It is our opinion that it is better to submit obediently to the majesty of the prince, than by refusing to carry out his orders, give an example of rebellion to the subject, bearing in mind always the qualifications we have already made. These principles hold good especially when it is a question of the honour of God which is, and ought to be, of more moment to the subject than the goods, the life, the honour of all the princes of this world ... But it is also necessary to beware of opening the door to rebellion on the pretext of conscience, or an ill-founded doctrine. So much for the obedience due from the magistrate to the sovereign. Let us now consider his powers over private citizens.

We have said that the magistrate is the officer who commands in the name of the commonwealth. The right of command belongs to him who has authority to constrain those who do not wish to obey his orders, or who 
disobey his provisions, and who can suspend his own prohibitions. When we say that the force of law lies in the fact that it commands and prohibits, permits, and punishes, we are speaking of the magistrate rather than the law, which is silent. The magistrate is the life of the law because he accomplishes these things. The commands and prohibitions of the law would be useless were it not for the penalties for contravention, and the magistrate who gives them effect.

Properly speaking the law is only concerned with prohibitions and the punishment of those who disobey, for a command implies a prohibition of any breach of that command. Law is not permission, for permission suspends prohibitions, and therefore carries with it no penalty or threat of punishment, without which there can be no law, seeing that law signifies nothing else than the command of the sovereign, as we have shown. But whatever penalties and threats of punishment may be attached to the law, they never follow in fact on an act of disobedience save through the agency of the magistrate. The force of all laws is therefore vested in those with power to command, whether it be the sovereign prince or the magistrate, for they alone can constrain the subject to obey, and actually punish him if he does not do so. Thus are those commands executed which Demosthenes calls the nerves of the commonwealth.

I have said that the magistrate has a public power of commanding, to differentiate his authority from domestic power. I have said he has power to constrain, to distinguish him from those who have only cognizance of causes, who can judge, and pass sentence, and cite before them, but who have no power of compulsion, or of executing their own judgements and injunctions. Such were the ancient pontiffs, and in our times the bishops. In ancient times commissioners appointed by the magistrates had cognizance of the causes committed to them and could pass sentence, and even summon parties before them. But they had no power of compulsion, and they had to submit their sentences to the magistrates for confirmation or rejection as seemed good to them ... Nowadays by our statutes and ordinances, the commissions issued to judges give them powers of compulsion, and they can execute their own sentences by means of their serjeants and other public persons, under commissions sealed with their seals. Bishops, having no such powers, 
report their sentences to the magistrates for execution....

The simplest kind of constraint that can be imposed by those who have powers of compulsion is seizure of body or goods. It is no good being able to summon an accused person, pass judgement on him, and impose a fine, unless one can seize the person or the goods of the convicted man who will not obey ... The magistrate has power to convict or acquit, and take cognizance some of matters concerning property, others concerning property and honour, and yet others of property, honour, and corporal pains exclusive or inclusive of the death penalty, with or without appeal from their decisions. The highest degree of compulsion is power of life and death, that is of condemning to death, or of pardoning those who have incurred this sentence. This is the highest attribute of sovereignty, proper to the majesty of a prince, and inherent in him to the exclusion of all other public persons.

It follows that there are two sorts of public persons with a right to command. One is the sovereign right which is absolute, unlimited, and above the law, the magistrates and all citizens. The other is the legal right, subject to the laws and the sovereign. This is proper to the magistrate, and those who have extraordinary powers conferred on them by commission. These persons can exercise the right only until their office is revoked or their commission expired. The prince after God recognizes no superior whatsoever. The magistrate, under God, holds his powers of the prince and exercises them subject to the prince and the laws. The citizen, under God, is each according to his degree subject to the prince, his laws, and his magistrates, each in his proper sphere. I should add that I comprehend under the name of magistrate all those who have rights of jurisdiction annexed to their fiefs, for these rights they hold of the prince just as does any other magistrate. Only sovereign princes have an absolute right to command, in the sense that they alone can use the phrase 'I ordain that ... '. The will of the magistrate, and of all others who have power to command is subject to the will of the sovereign, to which they are strictly bound, for he can revise, amend, or revoke his orders at will. Therefore the magistrates can never, either individually or collectively use the phrases 'for such is our good pleasure', or 'on pain of death' in the commissions they issue. Only the sovereign can do this in his ordinances. 
This raises an important question which has never been properly determined, and that is whether the power of the sword is peculiar to the prince and inseparable from his sovereignty, so that the magistrate has only the right of execution of high justice, or whether such power is proper to the magistrate because communicated to him by the prince.

But this point cannot be settled unless two other questions are resolved. First whether an office belongs to the commonwealth, to the sovereign, to him who holds it, or is common to the public and the subject; second whether the power which is delegated by the institution of a magistrate belongs to him to whom it is given in virtue of his office, or whether it belongs to the person of the prince, but is exercised by the magistrate, or is common to the prince and the magistrate. The first question presents no difficulty. All magistracies, jurisdictions, and offices whatsoever belong to the commonwealth (except in a despotic monarchy) and the provision only belongs to the sovereign. They cannot be appropriated by individuals except by the grant of the sovereign, the consent of the estates, or confirmed by long undisputed enjoyment, as is the case with the duchies, marquisates, counties and other feudal jurisdictions which were in ancient times commissions which could be revoked at will by the sovereign, but were subsequently granted for a man's life, and then to his heirs, male and then female, till they have become a form of patrimony in many kingdoms. The power of the sword and other feudal jurisdictions are now without doubt the property of the holders once they have rendered faith and homage, sworn to hold of the sovereign, saving always the right of appeal and other sovereign rights.

Although the powers of the marshals are only given them for the prosecution of war, nevertheless military discipline carries with it the power of the sword, although this is not expressly laid down by statute, and has nothing in common with the powers legally vested in police and other magistrates ... In all commonwealths the power of the sword belongs to marshals and captains in chief, without limitation, or restriction to any given form of procedure, or the ascription of given penalties to given crimes and misdemeanours. All is left to their judgement and discretion. They therefore cannot be regarded as simple 
executors of the law, for there is no law governing their modes of action. One must therefore conclude that in their case the power of the sword is transferred to them in person....

This point cleared up, we can proceed to the next. It follows that the powers granted to a magistrate by his institution to an office are proper to that office, since the office is not his personal property ... One can lay down as a general rule that whenever and in as much as magistrates or commissioners are obliged by laws and ordinances to use the powers committed to them in a strictly prescribed manner, whether in matters of procedure, or in the sentences they must inflict without power of increasing or modifying them, they are the simple executioners and ministers of the prince and the laws. No authority properly belongs to them whether it be a matter of police, or justice, or war, or diplomacy. But where they are allowed to use their own judgement and discretion, power and authority properly belongs to them. There are two principal considerations that magistrates in all commonwealths should have before their eyes, and those are the law and equity. That is to say there is always the question of how the law is to be executed, and of the function of the magistrate in relation to it. The word judgement should be confined to that which is ordained by the magistrate under the terms of the law. The word decree only refers to that which is based on the principles of equity and not law. For this reason the decisions of the prince are called decrees and not judgements, since the sovereign is not subject to the law. It is an error then to use the term decree for anything else than a sentence of the council proceeding from deliberations undertaken at the prince's instance, a sentence of the prince himself, or an order of a magistrate to which neither law nor custom binds him.

There is the same relation between equity and the function of the magistrate as there is between law and its execution. In the cases in which the magistrates are not bound by rigid rules of law they resemble arbitrators in a matter of right. Where they are strictly bound by the letter of the law they resemble judges appointed to take cognizance of the facts simply without power of adjudicating on the justice of the cause. In the one case their position is servile, in the other honourable, because in the one case they are bound by the law and in the 
other not. In the one case they are only concerned with determining the facts, in the other with determining what is right, so that in the former case the decision rests with the law, and not with them as in the latter case. By way of underlining this difference, the law allows no appeal from a sentence in which the magistrate has no option but to apply the letter of the law, except an appeal against conviction. But one can appeal against a sentence which depends on the discretion of the magistrate. The penalty inflicted by the law however is inflicted by the sovereign, from whom there is no appeal.

In ancient times it was usual to bind the hands of magistrates, governors, ambassadors, and generals in the field by compelling them by the strict letter of the law in what they undertook, the forms they used, and the penalties they inflicted, without power of addition or subtraction of any sort. Today the tendency is all the other way. There is hardly a state in which pains and penalties do not depend upon the consideration and arbitrament of the magistrate. In all civil cases he has complete discretion, without being bound in any way by the pains ascribed by Roman law or by decisions recorded in the courts. The Emperor Justinian caused a great deal of confusion by attempting to embody these latter in a code strictly binding on magistrates in the execution of their functions. But judges and jurists alike wished to do what they considered just, and that was often incompatible with ancient rules. In the end it was found necessary to leave all to the conscience and good faith of the judges, owing to the variety of circumstances, of places, and persons. This variety cannot be comprehended in any law or ordinance. And although there are still certain pains and penalties which are required by law to be inflicted without qualification in certain cases, nevertheless the magistrates do not keep to the restrictions. An example is the edict against coining published by King Francis I, inflicting the death penalty in cases either civil or criminal. The very parlements, bailiffs, and seneschals who registered it without demur do not keep it. They have found by time and experience that the edict is inequitable. The infinite variety of circumstances do not permit of uniform treatment. ...

The magistrate, when not in court or exercising his magisterial function, is no more than any other private citizen, and if he does 
anyone a wrong, he may be resisted and legal redress sought. But when exercising his function in his official resort, and not exceeding his powers, there can be no doubt that he must be obeyed whether he does that which is right or wrong, for so says the law. If he exceeds his sphere or his competence one is not bound to obey if the excess is notorious. The remedy is the appeal. If there is no possibility of appeal, or if the magistrate persists without deferring to his superior, then one must distinguish between the wrong that is irreparable and that which can be remedied. If the latter, the injured person has no right of offering any sort of resistance. If the former, for instance if it is a question of life or limb and the magistrate persists in proceeding to execute judgement without permitting appeal, in that case one can resist, not so much in order to defy the magistrate, as to defend the life of one in danger, provided always the action is disinterested. It is never permissible to resist the magistrate in the confiscation of property, even if he is exceeding his powers, and will not allow an appeal. One can proceed to appeal, or petition, or to bring an action against him, or by some other means. But there is no law human or divine that permits one to take the law into one's own hands, and use force against the magistrate, as some have argued. This opens the way to rebels to trouble the commonwealth. For if it is permitted to the subject to seek redress against the magistrate by force, by parity of argument one could similarly resist the sovereign prince, and trample the laws underfoot altogether....

Not only is it not permissible to offend or injure the magistrates by word or deed, but they should be honoured and reverenced as those to whom God has given power ... The magistrate on his side should merit respect for his justice, his prudence, and devotion, so that subjects should have sufficient occasion to honour him. He should not prejudice the honour of the commonwealth by his own unworthiness, for a fault committed by a magistrate is doubly reprehensible. By a provision in his laws Solon allowed the magistrate who was drunk in the exercise of his duties to be put to death. This illustrates how strongly vice was reprobated, and a good reputation expected in a magistrate. Many magistrates seek to avoid criticism by severity in judgement. Others seek popularity by pardoning freely. But the law condemns both excesses. Many of those who have discretionary powers of punishment not precisely 
defined by law make the mistake of thinking that equity supposes a greater leniency than the rigour of the law requires, imagining that equity does not spring from strict justice but from mercy. But equity is not to be identified with either justice or mercy, but is a balance which can incline either way. If the crime is greater than the penalties of the law cover, the magistrate with discretionary powers should increase them. If the misdemeanour is a light one, he should mitigate them. He should not aim at the reputation of a merciful magistrate; for this is a fault more to be avoided than a reputation for severity. For severity, though it is blameworthy, maintains the subject in obedience to the laws, and the sovereign who has instituted them. That is why the law of God expressly forbids the exercise of mercy towards the poor in giving judgement. ...

Concerning Corporate Associations, Guilds, Estates,[7] and Communities [CHAPTER VII][8]

HAVING discussed the family and its members, sovereign power, and magistrates, let us now consider corporate associations and guilds, beginning with their origins, proceeding to their powers and privileges, and concluding by deciding whether their existence is indispensable to the commonwealth. The difference between the family and a corporate association or guild, and the latter and the commonwealth, is the difference between the part and the whole. A community of a number of heads of households, or of a village, a town or a province can subsist without there being any commonwealth, and the family without there being any guild. But a group of families bound together by mutual trust forms a corporate association or community, and a group of corporate associations and communities bound together by sovereign power forms a commonwealth. The family is a natural community, the guild a civil one. The commonwealth is, in addition, a community governed by sovereign power, but it can be so small as to include no other civil communities or guilds, but to consist only of family groups. The word community is common to the family, the guild, and the commonwealth. The word corporate association properly speaking refers to a group of families, or a group of guilds, or a mixed group of both families and guilds.

The origin of all corporate associations and guilds is rooted in the 
family. As the principal stem put forth branches, so it was necessary to found separate households, hamlets, and villages, so that the family spread over a whole neighbourhood. But with the increase in numbers, it became no longer possible for them all to inhabit and find sustenance in a single place, and they were compelled to spread abroad. Gradually the villages grew into towns, each with its separate interests and distinct locality. As these communities were originally without laws, without magistrates, and without sovereign rulers, quarrels easily arose over such things as ownership of some spring or well. We find evidence of this in the Scriptures, and how the stronger party drove its weaker neighbours from their houses and villages. This led to the towns first surrounding themselves with ditches and then walls, and to men associating together, some for the defence of their homes and families, others to attack those in possession, and rob, despoil, and destroy them. The activities which were held in the greatest esteem among primitive men, says Plutarch, were the massacre, slaughter, and ruin of their fellows, and the reduction of them to slavery. We read also in Thucydides that conditions were the same throughout Greece only a little before his day, and brigandage was not in the least contemned....

This licence and impunity in preying upon one another compelled men, who knew neither rulers nor magistrates, to join together as friends for mutual defence one against another, and institute communities and brotherhoods ... A society or a community is rooted in mutual affection, that sacred flame which first springs into life with love between husband and wife, then between parents and children, then between brothers and their kindred, till it includes all those belonging to or allied to the family group. But it would have nickered out had it not been kept alight and fed by alliances, communities, corporate associations, and guilds, instituted by all sorts of people who knew no form of commonwealth, and were ignorant of the nature of sovereign power. This is illustrated in the book of Judges, where we read that the Hebrews were long without princes or magistrates, each living as he chose according to his own good pleasure, in perfect freedom. But they were bound together into communities of families and of tribes, and when harassed by their enemies, gatherings of the tribes met and chose a leader, whom God had inspired, to whom they gave sovereign authority. Many families and tribes thus united together by a sovereign power 
formed a commonwealth.

The first princes and lawgivers, not yet having discovered how to keep their subjects in the paths of justice, founded fraternities, guilds, and communities, for the parts and members of the body politic being thereby brought into agreement among themselves, it would be easier to regulate the commonwealth as a whole. Numa, the King and lawgiver of the Romans, established fraternities and guilds for all crafts, and to each fraternity appointed a patron, priests, and special sacrifices. Later a fraternity of merchants was founded, with Mercury as its patron, after the example of Solon, who permitted fraternities to be instituted for any sort of purpose, with power to make such statutes as they wished, provided they did not conflict with public law and custom. Lycurgus not only permitted, but strictly enjoined the setting up of such communities for both general and particular ends, and required all subjects to gather themselves into guilds of fifteen persons each for the purpose of common meals. These the Greeks called philitia because of the sworn friendship the members entertained for one another. In Italy similar guilds were called sodalitia because of the unity, intercourse and friendship, which bound together those who were in the habit of eating and drinking together. If differences arose amongst the associates, they composed them themselves, realizing that mutual trust is the foundation of any society, and much more necessary to men than justice. Justice is never pitiful. Involving as it does strict exaction of rights, it often makes enemies of friends. But mutual affection leads men to make concessions, and this secures that natural justice shall prevail. The sole end of all laws divine and human is to foster love among men, and between men and God, and this is best secured by intercourse and daily association ... Nowadays this is better observed among the Swiss than any other people in the world. In every town the fraternities and craft guilds have their guildhalls where they hold frequent banquets and festive meetings. The smallest village never lacks a communal hall for such purposes. Disputes are normally settled amicably, and the sentence recorded in chalk on the table at which they have eaten. As well as artisans and merchants, priests and bishops had their guilds and fraternities, and philosophers too, especially the Pythagoreans who lived together in common for the most part. 
So much for the origin and growth of corporate associations and communities, which in course of time have come to be regulated by laws, statutes, and customs, in all commonwealths. In order the easier to explain this last development, one can say that all corporate associations and guilds are instituted for the purpose of religion; or police, which includes the administration of justice and the distribution of obligations; or to regulate the food supply and the merchants who handle it, and the crafts necessary to the commonwealth; or for discipline. A guild can be confined to a single craft or profession, or type of merchandise or kind of jurisdiction. Or many guilds can form a single corporate association, such as a guild for all crafts, merchants dealing in all sorts of commodities, all branches of learning, or all the magistrates. Or many guilds can become a general community or university. And not only guilds and communities, but all the inhabitants of a village, a district or a province have the right of association, and can, together with the guilds and communities, assemble as Estates. Each of these can have its particular regulations, statutes, and privileges.

We can therefore say that a corporate association or a guild is a legal right of communal organization, subject to sovereign power. The word legal implies that it is authorized by the sovereign, for without his permission no guild can be instituted. It also implies there is a constitution of the guild, determining the time, place, and form of meeting, and the business it is competent to transact. The word communal signifies that there can be no college where there is no common bond, though it is not necessary that everything should be in common. It is enough if there is an assembly open to all colleagues, a common trustee, or a common purse. It is not necessary that there should be a common life. Some people have called it a guild when three or more persons live together and share their goods in common. But this is a double error. In the first place such a group is not a guild, but parties to a contract for the sharing of property. In the second place colleagues of a guild live in their own houses apart, as do fraternities of craftsmen.

There are no restrictions as to the number that may form a guild, save that it must be more than three. By colleagues, I mean those who are equal in respect of communal rights, each having a deliberative voice. 
But the guild, or the prince, can choose one of the colleagues to rule, correct, and punish each individual among his colleagues. Bishops and abbots have power to chastise canons and monks. But if the head of the guild has such power over the whole body considered collectively, it is not properly speaking a guild, but rather a form of the family, like the colleges of young scholars where none of the bursars have a deliberative voice. If some of the bursars have collegiate rights and a deliberative voice in the assembly, then it is a college even though the rest of the young scholars are subject to the power and correction of a principal. $\cdots$

The person chosen by the guild or the prince to have authority over all his colleagues individually has two characters, one in relation to each of the others, and one in relation to the guild as a whole. He is called the principal, the bishop, the abbot, the prior, the president as the case may be, having authority to command each of the others. But in relation to the guild as a whole he is just one of the colleagues, though he has precedence over the rest. That is why these distinctions are preserved in the terminology used, bishop, canons and chapter, abbot, monks, and convent, principal, bursars, and college. One of the greatest of the jurists[9] was in error on this point when he said that the philosophers use college for the persons who make it up. But no philosopher has said this, for college is a legal concept. The whole revenue and privileges of a college may be vested in one person, all the others having died. The college survives legally and its property cannot be seized for the fisc, nor by private persons until the college has been dissolved by the authority of the sovereign. ...

The origin and definition of a guild and a community having been demonstrated, its authority in general must be considered. These general matters cannot be ascertained from articles of incorporation, statutes, and particular privileges, for they are infinite in number, being diverse for the diversity of communities. The first corporate associations and guilds in any commonwealth, and those which are most influential, are the colleges of judges and magistrates. Not only have they authority over the minority of the college considered collectively, and over each in particular, but also over persons who are not members of the college, but subject to its jurisdiction. The peculiarity of 
colleges of this type by comparison with all others is that whereas guilds are established in general to regulate what is common, colleges of judges and magistrates are instituted chiefly for the purpose of regulating the affairs of outside persons, and even other colleges, and correcting them if they do anything contrary to their laws and statutes.

An upright man should be concerned first to be just in himself, before he starts administering justice to others, whence the Hebrews had a proverb that charity begins at home if it is to be true charity. Colleges of judges therefore should first establish a just order within their own ranks, before dispensing it to other people. It is therefore pertinent to consider whether it is better that colleges of magistrates should punish their own members, or submit the case to outsiders. To be brief, one must make a distinction. If the college is one of vicious men, the correction of their own vices should not be left to them. But if they are upright men there is no doubt that colleagues are better judged by the college than by other judges. There are imponderable values in each college which cannot be properly understood nor judged except by the members of that body. Moreover this reinforces the bond of union among the colleagues. For this reason the Emperor Adrian permitted a Roman senator only to be tried by the Senate. For the same reason civil suits between merchants, and suits concerning matters of trade have been very wisely conceded to the guilds and colleges of merchants, first throughout Italy and then in France. They decide summarily the disputes which arise out of contracts, which have peculiarities not found in other kinds of suits. As to other corporate associations and guilds, although they are not instituted for the purpose of justice or command, they nearly always have a limited power of coercion under their statutes and privileges. At times they even have unlimited powers, and correction is left to the prudence and discretion of the guild or its head. Such power should be exercised with the moderation that a father shows his son ... Canonists ascribe to abbots jurisdiction over their religious to the exclusion of the bishop, and this has been confirmed by a judgement of the Parlement of Paris. Monks cannot be brought before the magistrate even for what they did before entering religion. But this must be understood to refer to light and youthful follies only, otherw ise a way would be opened for robbers and murderers to retire into such communities, in preference to the forests, to escape punishment. 
As to the regulation of matters of individual interest to its members, in my opinion a guild cannot do anything without the consent of all the colleagues, as in the case of arbitrations. In all communities the express consent of each is required in all matters of common interest which concern all considered separately as individuals. But if it is a question of what is common to all considered collectively, then, if the greater part are agreed, they can oblige the rest, provided that what is to be ordained is not contrary to the statutes of the college as established by the sovereign, or by its founder and authorized by the sovereign. The ordinances of the commonwealth, and the statutes of the college not being slighted, the college can make regulations relating to the affairs of the community which bind both the minority as a whole, and each of the colleagues individually, provided that two thirds of the total number are present in the assembly, even if not agreed. But the majority considered as a corporate whole, still more the entire college, cannot be bound by their own statutes, any more than can the prince by his own law, the testator by his own will, or private individuals by their contracts, since they can be dissolved by common consent. Thus two thirds of the guild can repeal an ordinance made by the whole guild. This is a general rule applying to all communities, corporate associations, and guilds.

But in an assembly of estates made up of several corporate associations such as the Diets of the Empire, and the Estates of other commonwealths, which are composed of the three orders of clergy, nobles, and people, two of them cannot do anything to the prejudice of the third. Bodin, deputy for the third estate at Blois,[10] protested against the other two estates, with many forceful arguments, that the appointment of a body of thirty-six judges to examine the bills of recommendation presented by the Estates was prejudicial to the interests of the kingdom.

Whereupon the Archbishop of Lyons, president of the estate of the clergy, argued that the estate of the clergy and of the nobility had already settled the matter by so resolving. Bodin protested that from earliest times each of the three estates had jealously guarded its right 
not to be liable to coercion against its will by the other two. This principle had been accepted without question at the Estates of Orleans, and was the established practice in the Estates of the Empire, of England, and of Spain. He therefore prayed the other two orders to forgive him if he opposed the proposal, since he represented the interest of the third estate. This led forthwith to the matter being debated, and the estate of the nobility and the estate of the clergy changed their minds. That same day the king said in the presence of the Bishop of Angers and other seigneurs that Bodin had made the Estates dance to his tune. ...

To sum up on the subject of the powers of corporate associations and legitimate communities, the law of Solon is accepted on principle in all commonwealths, and approved by both jurists and canonists, that corporate associations and legitimate communities can establish such ordinances as they think in their best interests, provided they do not derogate from the statutes of the college, imposed or authorized by the king, or run counter to the ordinances of the commonwealth ... I do not agree however with those who say that a guild can make regulations, but cannot attach penalties to the breach of them. An ordinance has no force if there is no punishment for ignoring it, or if he who made the ordinance cannot compel its observation by penalties. We have any number of examples of craft guilds, legally incorporated, that have certain powers of coercion, of inspection of workshops and warehouses, and of seizure or confiscation of anything made contrary to the regulations, though the magistrate always has cognizance if they are resisted in so doing. ...

Let us now consider how an offending community can be punished... The acts of the majority of colleagues, or inhabitants of a town, agreed upon in their legally constituted assemblies, are the acts of the whole community or town. That is why in such a case the whole community is punished. Rebellions of towns, and insurrections of whole communities are punished by deprivation of privileges, of the right of association, by fines, imposts, enslavement, and other penalties according to the gravity of the case. But no such punishment should be inflicted unless the rebellion, or other crime, was committed by the will of the community, and agreed to in their formal assembly, as was decided by an 
order of the Court of the Parlement regarding the commune of Corbeil. Nevertheless if the penalty is corporal, even though the whole community should be convicted, only those who have consented should suffer it. But if the thing is done by some one particular person on the advice and with the will of the rest, they can each and all be prosecuted, and the punishment of one does not acquit the rest.

It may be argued that there seems little appearance of justice in punishing a whole community when the greater part were innocent of the offence. The alternative is however worse, and that is when victims are selected by lot, and the innocent run the same risk with the guilty that the choice will fall on them. This happened when the Roman army was decimated for having behaved with cowardice in the face of the enemy. The lot frequently fell on the bravest and most valiant, but they were executed for cowardice along with the rest. This incident was cited by the Senator Cassius when persuading the Senate to put four hundred slaves to death because one of their number had murdered their master. It is not, it is true, a solution of a problem to point out that the alternative action is worse. But one of the first principles of justice in action is that of avoiding among many inconveniences that which is the worst. When it is a question of crimes, it is of the first importance that they should not go unpunished....

The prince who suffers seditions and rebellions of the communities of his realm, whether towns or provinces, to go unpunished, gives encouragement to others to follow suit. Those who practice a remorseless cruelty, on the other hand, put the whole state in peril. He earns the reputation of a just prince, and preserves his state, who takes the middle course and only punishes the leaders of a rebellion. This was what Charles of France, afterwards King of Naples, did. Sent to chastise the inhabitants of Montpellier, he deprived them of their communal rights, consuls, and local jurisdiction, ordered the walls to be razed and the bells dismantled, and imposed a fine of one hundred and twenty thousand gold francs. Some writers say that one half of the property of the inhabitants was confiscated, and six hundred burghers executed by drowning, hanging, or burning. In effect however the matter was managed with more moderation and only the guilty were executed. Yet there had not been at Montpellier any assembly of the inhabitants, nor a 
deliberate conspiracy of the whole body. Even when all the inhabitants of a city have severally and collectively debated and decided upon a rebellion or a conspiracy, the wise prince will not punish them all, for fear of putting the whole state in danger....

It remains to be decided whether a commonwealth can dispense with associations and guilds. We have shown how men led by a sociable and companionable instinct, proceed to the foundation of communities of various kinds, estates, corporate associations, and guilds, till finally they achieve a commonwealth. After God, such communities have no surer foundation than friendship and goodwill among men, the which cannot endure unless fostered by associations, whether of estates, fraternities, corporate associations, or guilds. So to ask whether communities and corporate associations are necessary to the commonwealth, is to ask if the commonwealth can subsist without fellowship, which even the world itself cannot do.

I insist on this point because there have been those who think that corporate associations and guilds ought to be prohibited, forgetting that the family and the commonwealth itself are nothing but communities. It is an error that men of the best minds very often fall into, Because of some inconvenience attendant on a particular custom or ordinance, they want to abolish the whole thing, without considering what good it would do. I confess that the existence of ill-regulated communities entails a swarm of factions, seditions, cabals, monopolies leading at times to the total ruin of the commonwealth. Instead of mutual fellowship and charitable goodwill, one sees plots and conspiracies of one against another hatched. What is worse, under the veil of religion there have been societies practising a wicked and execrable impiety. There is no better example than the fraternity of the bacchanals in Rome. More than seven thousand persons were accused, convicted, and many executed or banished for the abominable misdeeds which they committed in the name of religion. This led to the suppression of the fraternities of the bacchanals throughout Italy by order of the Senate, confirmed by the people. A law was published forbidding sacrifices henceforth save in public. Long before this a Greek sage had argued with the Athenians that sacrifices under cover of darkness were extraordinarily suspect. It is much more conducive to the welfare of the commonwealth either to permit 
the public assembly of societies which claim religion as their purpose, or to prohibit them altogether, than to permit them to function as secret societies. For any sort of plot can be initiated in such secret sessions, and fostered till it infects the whole commonwealth. This is what happened at Münster where the Anabaptists multiplied in secret to such an extent that they invaded the whole state of Westphalia...

Therefore in answer to the question whether it is a good thing to have Estates and colleges, or whether the commonwealth can well dispense with them, I hold that there is nothing that contributes more to the security of popular states and the ruin of tyrannies; for these two types of commonwealth, contrary in themselves, owe their preservation or destruction to contrary conditions. Similarly aristocracies and rightly ordered monarchies are preserved by a moderate provision of Estates, corporate associations, and well-regulated communities. Popular states therefore encourage all forms of guilds and corporate associations, as did Solon when he set up a popular state in Athens. But the tyrant tries to eradicate them altogether, knowing full well that unity and bonds of friendship among his subjects spells his inevitable ruin. The good King Numa was the first to institute guilds of craftsmen. Tarquin the Proud was the first to suppress them and prohibit assemblies of the people. He even tried to get rid of the Senate by compassing the death of individual senators without making any new nominations. But immediately he was expelled popular assemblies were restored, the ranks of the Senate filled, the suppressed craft guilds revived. This policy was continued until they had reached a total of about five hundred, and had become so powerful as practically to rule the state, when the Senate abolished them. Nevertheless Claudius the Tribune, who renounced his title to nobility, and got himself adopted by a simple merchant, in order to qualify for the Tribune's office, restored and enlarged the guilds and fraternities in order to balance the nobles by the people. But the moment Caesar was made dictator he abolished them to enhance his own power and overthrow theirs. Once Augustus was secure in power however he restored them by express edict. Nero the tyrant suppressed them again. For tyrants have always hated popular associations and alliances. ...

But a just monarchy has no more secure foundations than the support of 
popular Estates and the communities of the realm. For whenever there is occasion to raise money, assemble the armed forces, or defend the state against the enemy, these things can hardly be compassed except by means of Estates-Generals, or Estates of each province, town or community.

Even those who wish to abolish Estates haven't any recourse save to them in times of necessity, for once assembled to gether the people find the will and the strength for the defence and safety of their princes. This is especially so when an Estates-General of all the people is assembled in the presence of the sovereign. Matters touching the whole body of the commonwealth, and each of its members are there made public. There the just complaints and grievances of poor subjects, which otherwise would never reach the prince's ears, are heard and attended to. There the frauds, depredations, and usurpations committed in the prince's name, but entirely without his knowledge, are discovered. It is extraordinary what satisfaction subjects get from seeing their prince preside in their assemblies, how proud they are to appear in his presence. If he hears their complaints and receives their petitions, even though he must frequently refuse them, they are exalted by the mere fact of having had access to their prince. This practice of holding Estates is better observed in Spain than anywhere else in the world, for they meet every two or three years. This is also the case in England, for the people will not give up their control of taxation, so Parliament must meet....

I have said that moderation, which is in all situations a virtue, ought to be observed with regard to all kinds of associations and guilds in aristocracies and royal monarchies. To abolish all such societies is to embark on a barbarous tyranny and so ruin the state. But it is also dangerous to permit all sorts of assemblies and fraternities whatsoever. They are often a cover for conspiracies and illicit monopolies, of which we have had only too many examples. This is the reason why it has been found necessary from time to time to abolish fraternities by express edict, though such edicts have been very ill-observed. It is better however to get rid of abuses only, rather than root out good and bad alike. ...

1. Though this book is devoted to an analysis of the types of public 
functionaries characteristic of the commonwealth as such, Bodin has France in mind all through as his model, and so assumes a certain familiarity in the reader with French institutions. For elucidation of much of what he says in this book and elsewhere see R. Doucet, Les institutions de la France au XVIe siècle, 1948; and A. Esmein, Cours élémentaire d'histoire du droit français, 1892, etc.

2. There were many occasions when such a balm was set up in Florence. Bodin probably has in mind the one set up in 1434 under cover of which the Medici established their political dominance in the following 50 years.

3. After the war of the Public Weal, by an Ordinance of October $21 \mathrm{st}$, 1467, the King pledged himself to fill no office 'unless vacant by death, voluntary resignation, or by forfeiture previously adjudged after sentence in a court of law'. In effect this made officers of the crown irremovable. It was however frequently violated, and only when offices in general became purchasable, under Francis I, were their holders secure.

4. Lettres de justice were designed to mitigate the rigour and rigidity of the customary law in civil cases. They were issued when parties in civil suits wished, for instance, to appeal against a judgement, or plead hardship in the strict application of the law, or contest the validity of a deed on grounds of some irregularity. They were directive, not compulsive, empowering the judge to admit the plea, but leaving the decision to him. Mandement was a term of much more general application, covering all orders indicating the king's will in the matter. For instance, the letters patent communicating to the élus the amount to be raised in taxation in their several districts were mandements. So also were the letters permitting members of the privileged orders to buy salt free of gabelle. The claim had to be verified by the Chambre des Comtes. Most important, to Bodin's mind, were the mandements bestowing any kind of royal gift or grant. They required verification as to the facts by the college of the four Trésoriers de France.

5. The terrible Albert Alcibiades of Brandenburg-Culmbach. He took advantage of the revolt of the Lutheran Princes against Charles $\mathrm{V}$ in 
1552 to wage his private war of aggression on the Bishops of Franconia, which was distinguished for the ferocity with which he devastated the countryside.

6. Bodin was thinking of the custom requiring the registration of royal edicts by the Parlement of Paris. (In his time the Parlement offered considerable resistance, especially to edicts concerning religion.) Hence for him legal responsibility for consent belongs not to the Estates representing the three orders, but to the Colleges of Judges who administer the law.

7. The terms are, corps, colleges, états, communautés.

8. Chapter VI is concerned with the relations of the different grades of officials to one another. But it adds nothing in principle to Bodin's account of the nature of magistracy.

9. There is a marginal reference to Bartolus.

10. These Estates met in December-January 1576-77, a few months after the publication of the Six books of the Commonwealth. The passage was added in all editions after 1577 . The point of the measure was to secure that the proposals of the Estates should be embodied in the forthcoming Ordinance. But the third estate feared its interests would be swamped. Bodin moreover objected on principle to dictation by the Estates to the king.

\section{BOOK IV}

The Rise and Fall of Commonwealths [CHAPTER I]

COMMONWEALTHS originate either in a family which gradually grows into one; or a specific agreement among some chance assemblage of men; or by colonization from some older commonwealth, as when a new swarm of bees leaves the hive, or a cutting from a tree roots and bears fruit more quickly than a plant raised from seed. In all cases the commonwealth can 
be founded either in violence or in consent. In the latter case a certain number surrender their full and entire liberty and submit themselves to the sovereign power of the others to be their sovereign rulers without law, or alternatively to be their sovereign rulers subject to certain conditions and fundamental laws.

Once the commonwealth has come into existence, if it is well ordered, it can secure itself against external enemies or internal disorders. Little by little it grows in strength till it reaches the height of its perfection. But the uncertainty and mutability of human affairs make it impossible that this pre-eminence should last long. Great states often fall suddenly from their own weight. Others are destroyed by the violence of their enemies at the very moment when they feel themselves most secure. Others decay slowly and are brought to their ends by internal causes. As a general rule the most famous commonwealths suffer the greatest changes of fortune. This is no occasion of condemnation, especially if the change is due to external forces, as most often happens, for the most successful states are those that most provoke envy ... Wherefore it is of the greatest importance to understand the causes of these revolutions before either condemning or emulating.

I mean by change in the commonwealth, change in the form of government, as when the sovereignty of the people gives way to the authority of a prince, or the government of a ruling class is replaced by that of the proletariat, or the reverse in each case. If the constitution of the sovereign body remains unaltered, change in laws, customs, religion, or even change of situation, is not properly a change in the commonwealth, but merely alteration in an already existing one. On the other hand the form of the government of a commonwealth may change while the laws and customs remain what they were, except as they affect the exercise of sovereign power. This happened when Florence was converted from a popular state into a monarchy. One cannot therefore measure the duration of a commonwealth from the foundation of a city, as does Paolo Manucci,[1] when he says that Venice has endured for twelve hundred years. It has changed three times in that period. It is possible also that neither the city, the people, nor the laws suffer any change or loss, yet the whole commonwealth perishes. This happens when a sovereign prince voluntarily subjects himself to another, or leaves his state by 
will to a popular democracy. Atalus, King of Asia, Coctius, King of the Alps, and Polemon, King of Damasia made the Roman Republic the heirs of their states. But this was not so much a change in the form of commonwealth as a total abolition of sovereign power. On the other hand if a single city or province constitutes itself one or more popular states or kingdoms, this is not a change of commonwealth but the foundation of one or more new states. This happened when the Swiss Cantons and the Grisons, heretofore vicariates and provinces of the Empire, constituted themselves eighteen distinct commonwealths. ...

All change is voluntary or necessary, or mixedly both. Necessity can also bring about a natural or a violent occurrence. Birth is more excellent than death, but in observing the course of nature we come to understand that they are inseparable; the one cannot be without the other. Death is more tolerable when it is the consequence of old age, or follows in the train of a long and insidious malady. Similarly in the case of commonwealths, with the lapse of centuries their very age necessarily brings about their downfall, and not always by violence, for one cannot describe as violent that change which happens to all things in this world in the ordinary course of nature. Change however need not always be from good to bad, from life to death, but can also be progression, from that which is good to that which is better, whether as the result of a slow process of natural development, or of some sudden and violent alteration. Voluntary change is of course the smoothest and easiest of all. Whoever is invested with sovereign power resigns it into the hands of others, and so brings about a change in the form of the commonwealth. The change from a popular state to a monarchy when Sulla was dictator was extraordinarily bloody and violent, but the reverse change from a monarchy, disguised as a dictatorship, back to a popular state was temperate and easy. He voluntarily resigned his sovereign authority to the people, no force or violence was necessary, and everyone was satisfied. There was a similar occasion in Siena when it changed from an aristocracy to a popular state after the tyranny of Pandolfo. It was accomplished with the full consent of the magnates, who willingly resigned their authority into the hands of the people, and left the town.[2]

A man can pass from sickness to health, or health to sickness as a 
result of either external causes, such as his diet, or internal causes effecting bodily or mental changes, or of such accidental causes as wounds, or curative medicine. Similarly a commonwealth can suffer change and decay at the hands of friends or enemies internal or external, whether it is a change for the better or for the worse. Such changes are often accomplished against the will of the citizens who, if there is no alternative, must be constrained and compelled, as doctors constrain and compel the insane for their own good. Lycurgus converted Sparta from a monarchy to a popular state against the will of the citizens, or at any rate the greater part of them. They attacked and wounded him, although he was resigning for himself and his successors the claim to the throne which belonged to him as a prince of the blood, and nearest in the line of succession.

I have already said that there are only three forms of commonwealth. It follows that there are properly speaking only six types of revolution that can befall them, that is to say from monarchy into a popular state and from popular state into monarchy, or from monarchy into aristocracy and aristocracy into monarchy, or from aristocracy to popular state and popular state into aristocracy. But each form of commonwealth can undergo six kinds of imperfect revolution, that is to say from kingship to despotism, despotism to tyranny, tyranny to kingship, kingship to tyranny, tyranny to despotism, despotism to kingship. The same changes can occur in the other two forms of the commonwealth, for an aristocracy can be legitimate, despotic, or factious, and a popular state legitimate, despotic, or anarchic. I call the change from a legitimate aristocracy to a factious one, or from a tyranny to a monarchy imperfect, because there is only a change in the quality of persons governing, good or bad. But sovereignty remains in the monarch in one case, and in the aristocracy in the other. ...

Men often enough die untimely, before they reach old age, in the very flower of their youth, or even in childhood. Likewise there have been commonwealths that have perished before they have achieved any distinction in arms or in laws. Some indeed have been abortive, or perished at birth, like the city of Münster in the Empire of Germany, dismembered from the Empire by the sect of the Anabaptists under their king, John of Leyden. He entirely changed its form of government, its 
laws and its religion. Throughout the three years of his reign the city was continuously beseiged, till at last its defences were forced and its king publicly executed. ...

I hold a commonwealth to be in its prime when it has reached the highest pitch of perfection and of achievement of which it is capable, or perhaps more accurately, when it is at its least imperfect. This can only be judged after its decline and fall. Rome passed through the stages of monarchy, tyranny, aristocracy, and popular government, but it reached its highest perfection as a popular state, and during that phase of its history it was never so illustrious in arms and in laws as in the time of Papirius Cursor ... Never after that time was military and domestic discipline so well maintained, faith better kept, the rites of religion more piously observed, vice more severely punished; never afterwards could it boast such valiant citizens. If it is objected that it was still poor and confined within the frontiers of Italy, I would answer that one cannot measure excellence by riches, nor perfection by the extent of the conquered territories. The Romans were never more powerful, rich, and mighty than under the Emperor Trajan. He crossed the Euphrates and conquered a great part of Arabia Felix, built a bridge over the Danube whose ruins we can still see, and humbled the barbarous and savage peoples of those times. Nevertheless ambition, avarice, and luxury had so corrupted the Romans that they only retained a shadow of their ancient virtue ... Such are the considerations which one must bear in mind if one is going to understand revolutions, though they have never been properly treated before.

There are many causes of revolution in the form of the commonwealth, but they can all be reduced to certain few fundamentals. There are first the struggles for power that develop among the magnates whenever there is a failure of heirs in the royal line, or when the great mass of the people are very poor, and a small handful excessively rich, or where there is great inequality in the distribution of estates and of honours. Or revolutions may be brought about by the ambition which incites some men, or the desire to avenge injuries, or the fear of punishment only too well deserved. Again changes in law or in religion, the cruelty of tyrants, or the indignation with which men see the highest offices in the land defiled by the bestial and voluptuous behaviour of their 
occupants, all precipitate revolutions.

I have already said that the original rulers and founders of commonwealths were violent tyrants, but their successors were in some cases despots, in others kings ruling by hereditary right. Further changes were due to the causes I have already indicated. Thus it is that all the histories, sacred and profane, agree that the first form of a commonwealth, and the first creation of a sovereign power, was to be found in the Assyrian monarchy. Its first prince, Nimrod, whom many call Ninus, made himself sovereign by force and violence. His successors ruled as despots, assuming an absolute right to dispose of the lives and goods of their subjects as they thought fit until Arbaces, governor of Media, dethroned Sardanapalus, the last Prince of Assyria, and made hims elf king in his stead, without any form of election. He was able to do this because Sardanapalus was given over to the vice of luxury, spending his time among the women instead of the men of his court, and men of spirit will not endure to find them selves subjects of one who is a man only in appearance. We read also that the Princes of the Medes, descended from Artabazus, the Kings of Persia, Egypt, and the Kings of the Hebrews, the Macedonians, the Corinthians, the Spartans, Athenians, and Celts all ruled by hereditary succession over kingdoms for the most part founded in force and violence, though they subsequently came to be regulated by good laws, and in accordance with the principles of justice.

This state of affairs continued until either there was a failure of heirs in the royal line, or till some prince, abusing his power, maltreated his subjects and so was expelled or killed. Thereupon their subjects, fearing perhaps that they would fall again under a similar tyranny if they gave sovereign power to a single person, or perhaps merely reluctant to submit to the commands of someone who had been one of themselves, founded an aristocracy, with scant regard however for the wishes of the mass of the people. If by any chance some among the poor and humble citizens also wanted a share in sovereignty, they beguiled them with the fable of the hares who wished to command lions. Even if monarchy was succeeded by a popular state, it was always arranged that the rich or the nobly born should monopolize all public offices, and occupy laws and estates. Thus Solon, having founded a popular state, 
would not allow the poor and humble citizen to have any share in the distribution of land. Again when the Romans expelled their kings, though they proceeded to found a popular state, they reserved lands and benefices to the nobility. We also read that after the first tyrants were expelled, warriors and soldiers were always endowed with estates, and the poorer people passed over, until Aristides and Pericles in Athens, and Canuleius and other tribunes in Rome opened all offices, and places and sources of profit, to all subjects alike. Since their time people have discovered by the experience of many centuries that monarchy is a more stable, a more desirable, and a more durable form of commonwealth than either aristocracy or democracy, and that the best monarchies are those in which there is a right of succession in the male line. In consequence hereditary monarchies have been established throughout the world. In some places however fear of what would happen were there a failure of heirs male has led to the prince being given the right to choose his successor, as did many Roman Emperors, and nowadays many African rulers. In other cases the right of the election of the successor of a prince who dies without heirs reverts to the people, or in some cases, in the kingdoms of Poland, Bohemia, Hungary, Denmark, Norway, and Sweden, the people elect even if there is an heir.

When the people have been ruled by a tyrant they always choose a just and merciful prince, when by a coward, a weak king, or a scholar, they look for some valiant captain. After the death of Numa, who only concerned himself with matters of morals and religion, the Romans elected the good captain Tullius Hostilius. It therefore generally happens that the cruellest and most ruthless tyrants are succeeded by just and equitable princes. They have before their eyes the miserable end of the tyrant, and fear a like fate for themselves; or they may have been well-educated in sound principles; or they may have been bound by an oath on their coronation, which curtails their authority. Thus we see that after the miserable death of Mark Antony Augustus governed most wisely and virtuously a state which flourished in arms and in good laws. $\ldots$

It is no matter for wonder if there have been few virtuous princes. There are, after all, few virtuous men, and princes are not usually chosen even out of this small handful. It is therefore remarkable if one 
does, among many, find one excellent ruler. And once such a one is exalted to a position in which he has no superior save God alone, assailed as he then is by all the temptations which are a trap even to the most assured, it is a miracle if he preserves his integrity. But if a prince arrays himself in the full splendour of justice, the flame he kindles shines long after his death, so that his sons, even if they should prove evil in their ways, are loved for the memory of their father. Cambyses, cruel and evil as he was, was always adored by his subjects, and respected by the rest, for love of the great Cyrus, his father. Affection for the great Cyrus was so engraved on the hearts of his subjects, that as Plutarch says, they admired anyone with a long aquiline nose for no other reason than that Cyrus was so featured.

The tyranny of a single prince therefore does not bring a commonwealth to the verge of revolution if he is the son of a good father. His estate is like a great tree which has as many roots as it has branches. But the self-made prince, who has no predecessors, is like a tall tree without roots, liable to be overthrown by the first gust of wind. If the son and successor of a tyrant follows in his father's footsteps, he and his whole government are liable to be overthrown by a revolution. The son has no security and is unpopular on account of his father's as well as his own vices. If he cannot get help from his neighbours, or alternatively is not upheld by strong armed forces, he lives under a perpetual threat of expulsion, unless, of course, he is the successor of a long line of kings. I say this because the virtue of a self-made king is never sufficient to secure possession to his son, should that son play the tyrant. ...

Revolutions come all the quicker if the tyrant is an oppressor, or cruel, or a voluptuary, or something of all these things as were Nero, Tiberius, and Caligula. But princes have been brought to ruin more through the vice of licentiousness than for any other cause. It is much more dangerous a threat to the prince's security than a reputation for cruelty. Cruelty keeps men in fear, and inactive, inspiring the subject with terror of his prince. But viciousness moves the subject to hatred and contempt of his prince, for it is very generally believed that the voluptuary is a coward at heart, and that the man who cannot command himself is unworthy to command a whole people. Sardanapalus, King of 
Assyria, Canades, King of Persia, Dionysius the Young and Hieronymus, Kings of Sicily ... Galeazzo Sforza, Alessandro de' Medici, the Cardinal Petruccio, tyrant of Siena, all lost their realms as a result of their own viciousness, and the most of them also were killed in the act... But states are not so easily brought to the point of revolution through the cruelty of a prince, unless it be the extreme and bestial cruelty of a Phalaris, a Nero, Vitellius, Domitian, Commodus, Caracalla, Ezzelino of Padua, or Giovanni Maria of Milan who were all killed or driven out, and their tyrannous governments supplanted by popular rule. This fate befell them not so much for their cruelty to their humbler subjects (to whom scant attention is paid in tyrannies) but for acts of individual cruelty committed against the magnates and men of good family. Often the cause of the catastrophe is not so much a cruel act as one that puts shame upon a man, for to be shamed is more intolerable to men of honour than to suffer cruelty. Bodila killed Childeric together with his wife and unborn child for having had him whipped ... The murderers of tyrants have nearly always seized the government, or the highest magistracies as a reward for their action. Both Brutuses seized the highest offices in Rome, the one for having driven out Tarquin, the other for having assassinated Caesar... Luigi Gonzaga having killed Bonaccorsi, tyrant of Mantua, was elected ruler by the subjects, and his posterity has continued in the government for two hundred and fifty years. The Venetians secured the lordship of Padua after they killed the tyrant Ezzelino. ...

All monarchies newly founded on the ruins of an aristocratic or popular state took their beginnings from the moment when one of the magistrates, captains, or subordinate governors, having force at his disposal, raised himself from the position of colleague to that of sovereign; or from conquest by a foreign power; or from voluntary submission to the law and government of another. The first is by far the most usual occurence, and there have been any number of examples ... the Decemvirate in Rome and after them Sulla and Caesar, the Scaligeri in Verona, the Bentivoglio in Bologna, the Malatesta in Rimini, the Baglioni in Perugia, the Sforzas in the duchy of Milan. But many others besides these have by force and violence advanced from the position of a simple captain, or provincial governor, to that of sovereign lord. For in matters of state one can take it as a general rule that he who is in control of the armed forces 
is master of the state. It is for this reason that in well-ordered aristocracies and popular states the highest honours in the state are not the positions of most effective power, and further, the most responsible magistracies are always shared by a group of colleagues. If this is not possible, and indeed in time of war such an arrangement is positively dangerous, the term of office is always very short. Thus the Romans instituted two consuls who commanded on alternate days. For although the dissensions which so easily arise between two officials equal in authority sometimes hold up the execution of business, the commonwealth is not so exposed to the danger of conversion into a monarchy as when there is a sole magistrate. For the same reason the Roman dictator was only appointed for such a term as the crisis required. It was never longer than six months, and sometimes lasted only a single day. The time expired, his authority to command expired, and if he continued to keep his forces in being, he could be accused of treason against the Republic ... It is therefore of the utmost importance that the laws governing the terms of office should be preserved without modifications, and the legal terms not prolonged except in cases of extreme necessity ... If the law had been thus strictly observed, Caesar would never have seized control of the state. ...

The conversion of a popular state into an aristocracy is generally the result of defeat in battle, or some other notable injury at the hands of an enemy. On the other hand a popular state is secured and strengthened by victory. These tendencies are illustrated in the histories of two commonwealths, Athens and Syracuse. The Athenians, who till then had enjoyed a popular form of government, having been defeated by the Syracusans through the fault of their captain, Nicias, fell under the dominion of four hundred citizens, though by a trick of Pisander they were known as the Five Hundred. When the humbler citizens tried to resist, they were overcome because the four hundred could dispose of the armed forces, and used them to kill the leaders and keep the rest in awe. But the Syracusans, puffed up by victory, destroyed their aristocracy and set up a popular state. A little later, the Athenians, on learning of the defeat of the Spartans by Alcibiades, killed or expelled their four hundred rulers and restored the popular state under the leadership of Thrasilus ... We read also that the Florentines, on hearing of the sack of Rome and the captivity of Pope Clement,[3] at 
once got rid of the oligarchy that he had established in Florence. They persecuted, killed, or banished the partisans of the Medici, threw down their statues, broke open their treasuries, expunged their names from all buildings in the city and re-established the popular state. Again, the moment the Swiss Cantons had defeated the nobles in the battle of Sempach in 1377, there was no more heard of an aristocracy, nor of recognizing the Emperor in any form whatsoever. The reason for a revolution of this sort is the inconstancy and rashness of a populace, without sense or judgement, and variable as the winds. It is stunned by defeat and insupportable in victory. No enemy is more fatal to it than success in its own undertakings, no master so wise as the one that imposes the severest restraints on it, in other words, a victorious enemy. In such a crisis the wiser and richer citizens on whom the greatest burden falls, seeing dangers threaten from all sides, take the conduct of affairs, abandoned by the people, into their own hands. Indeed, the only way to secure the continuance of a popular state is to keep it at war, and create enemies if they do not already exist. This was the chief reason which led Scipio the Younger to try and stop the razing of Carthage. He had the wisdom to foresee that a warlike and aggressive people like the Romans would fall to making war on each other, once all external enemies were disposed of ... But popular states are more likely to change into monarchies as a result either of civil war, or of the folly of the people in giving too much power to an individual. ...

On the other hand when a tyranny is overthrown as a result of a civil war, it is nearly always succeeded by a popular state. This is because the people know no moderation, and once the tyrant is expelled, the hatred of his memory, and the fear of once again falling a victim, excites them to rush to the other extreme ... This happened in Rome after the expulsion of Tarquin the Proud, and in Switzerland, once the Imperial Vicars were killed, the people established a popular state which has lasted till the present day, that is to say for two hundred and sixty years. ...

It also sometimes happens that a people is so unstable that it is impossible to find any form of government with which it does not become discontented after a brief experience of it. The Athenians... the 
Florentines and the Genoese were like this. The minute they had established one form of government, they began to long for another. This malady particularly affects those popular states whose citizens are of an active and enquiring turn of mind, as were those whom I have mentioned. Each citizen thought himself fitted to command the rest. When the citizens are of a less restlessly intelligent type they submit complacently to being ruled, and are easily brought to a decision in their public assemblies. More subtle spirits argue the point till intention evaporates in words. Personal ambition prevents anyone deferring to his opponent, and the state is thereby brought to ruin ... It is a matter of common knowledge that Florence is the nursery of ingenious spirits. How much the Florentines differ from, say, the Swiss in this respect. Nevertheless though both peoples substituted a popular state for a monarchical form of government about three hundred and sixty years ago, while the Swiss have preserved their popular institutions... the Florentines have never ceased to change and change again, behaving like the sick man who keeps on moving from one place to another, thinking thus to cure the illness which is attacking his very life. In the same way the malady of ambition and sedition never ceased to afflict Florence until a physician was found to cure her of all her ills. A monarch succeeded who built fortresses in the city, garrisoned them strongly, and by such methods maintained a government which has lasted for forty years now.[4] ...

Aristocratic states are more stable and longer lived than popular ones, provided that the ruling class avoid the two dangers of faction within their own ranks, and attack from a rebellious populace outside them. If they once start to dispute amongst themselves, the people will never fail to seize the opportunity to fall upon them, as the history of Florence shows only too well. This danger is intensified when foreigners are freely admitted into the city and settle in large numbers. Not being qualified for office, when they are heavily taxed or oppressed in any way by the governing body, their ready remedy is to rise and expel the native rulers ... This is the danger which most threatens the state of Venice. It is a pure aristocracy. But it has admitted foreigners in such numbers that by now for every Venetian gentleman there are a hundred citizens, both nobles and burgesses, of foreign extraction. ... 
The change from aristocracy to popular state has nearly always been bloody and violent. On the other hand the reverse process of change from popular state to aristocracy nearly always comes about gradually and peacefully. This happens when a city admits foreign settlers who in course of time considerably increase in numbers, but who remain ineligible for office or political rights. The strain of government and of war brings about a gradual diminution in the ruling class, whereas the number of aliens steadily increases. A point is reached when it is only a minority of the inhabitants who enjoy rights of sovereignty, and this, we have shown, is the distinguishing mark of an aristocracy. The commonwealths of Venice, Lucca, Ragusa, and Genoa were all once popular states which have gradually and insensibly been converted into aristocracies. The change was further facilitated, of course, by the reluctance of the poorer citizens, who needed all their time and energy to make a living, to accept public duties to which no profit was attached. In course of time, and by prescription, their families have lost the right to such offices altogether.

This type of revolution is the easiest and least insupportable of any. But if one wishes to prevent it happening, the children of immigrants must be admitted to public charges and offices, unless there are very urgent reasons why not, especially if the commonwealth is much involved in wars abroad. Otherwise there is the danger that the ruling class, not daring to arm its subjects, will be destroyed by defeat in battle, whereupon the people will seize power ... The thing that most assisted the victory of the Roman people over the nobles was the defeat of the latter by the men of Viei, for the greater part of the gentry were killed, including three hundred members of the most ancient and noble family of the Fabii. The Venetians solve this problem by employing foreign mercenaries as a general rule, if they have to make war, though they avoid doing so whenever possible.

This danger of a revolution in the form of the state, following the destruction of the nobles, does not afflict monarchies, except in the extreme case of all Princes of the Blood perishing with the nobles. The Turks have seen to it that no single gentleman escaped in any province which they intended to annex. But this sort of change is rather the absorption of one state by another than a revolution in government, and 
proceeds from external and not internal causes. But practically the entire noblesse of France was killed in the battle of Fontenoy near Auxerre, in the war between Lothar, son of Louis the Pious, and his brothers Louis and Charles the Bald. Nevertheless all three monarchies survived as such....

Great and notable revolutions are most likely to befall aristocracies and popular states. There is no more common occasion than the ambition of proud men, who cannot obtain the rewards on which they have fixed their desires, and so constitute themselves the friends of the people and enemies of the noblesse. Thus did Marius in Rome, Thrasibulus in Athens, Francesco Valori[5] in Florence, and many others. This is all the easier to accomplish when unworthy persons are preferred to positions of honour and trust, and those who are worthy of them excluded. This angers men of birth and position more than anything else. What most contributed to the ruin of the Emperors Nero and Heliogabalus was the promotion of despicable persons to the highest honours. But this danger is greatest in an aristocracy governed aristocratically, that is to say where the generality of people have no share in office. It is a two-fold grievance to find not only that one is excluded from all offices and benefices, but that these are monopolized by unworthy persons to whom one must submit and do reverence. In such a case those patricians who can organize a following, can change an aristocracy which has no foundations in popular support, into a popular state. This cannot happen if the ruling class preserves its solidarity. Divisions and antagonisms within the ruling class is the danger most to be feared in the aristocratic state. ...

Revolutions tend to occur more frequently in small commonwealths than in those which are large and populous. A small commonwealth easily falls into two hostile camps. It is not so easy for such a division to appear in a large one, for there are always a number of people who are neither great nor humble, rich nor poor, good nor evil who form links between the extremes, because they have affinities with each. We find that the small republics of Italy and ancient Greece, consisting of one, two or three cities only, suffered many and diverse changes of form. There can be no question but that extremes always lead to conflicts if there is no means of uniting or reconciling them one with another. One can see at a 
glance the jealousy which divides noble and tradesman, the rich man and the poor man, the virtuous and the vicious. But more than this, one sometimes finds that the conflicting interests of different localities in the same city bring about a revolution... We read in Plutarch that the Republic of Athens was harassed by seditions and disorders because the sailors who inhabited the port were separated from those who lived near the Acropolis, and extremely hostile to them till Pericles included the port within his long walls. Venice was at one time in extreme danger from a similar conflict between the sailors and pilots on the one hand, and inhabitants of the city on the other, and but for the intervention of Pietro Loredano[6] would have suffered a violent revolution.

Internal seditions often bring about external disasters, for a neighbouring prince very frequently falls upon an adjacent state in the hour of its defeat, as did the Normans after the battle of Fontenoy when the noblesse of France was practically exterminated ... External disasters attendant on internal disorders are all the more to be feared if one's nearest neighbours are not friends and allies. Proximity whets the appetite for securing that which belongs to another, before he can prevent it. There is nothing surprising in this. When one considers that neither seas, mountains, nor uninhabitable deserts are sufficient barriers against the ambition and avarice of princes, how can one expect them to be content with what they possess, and refrain from encroaching on their neighbours, when their frontiers coincide, and opportunity offers?

Such a fate is much more likely to befall small republics such as Ragusa, Geneva, or Lucca, which consist of a single city and a very small dependent territory. Who conquers the city conquers the state. This cannot happen to great or powerful commonwealths which have many provinces, and many local centres of government. If one is occupied, the others can come to its assistance, as several members of a powerful body who can aid one another at need. Moreover monarchies have this advantage over aristocracies and popular states, that there is no one centre of sovereignty which is the stronghold of the ruling class, so that if it is destroyed the state perishes. A king can remove his capital from place to place. Even if he is himself captured, the ruin of the state does not necessarily follow. When the city of Capua was taken by the 
Romans the whole state perished, and no other city or fortress offered the least resistance, for the sovereign, senate, and people had all been made captive. Again when the Duke of Florence took the city of Siena all its subjects, cities, and fortresses surrendered forthwith. But should a king be made captive, he is often released again for the price of his ransom. Even if the enemy will not be content with that, the estates can always proceed to another election, or enthrone the next in blood if there are other princes. A captive king will sometimes rather lose his throne or die a prisoner than afflict his subjects. The Emperor Charles $\mathrm{V}$ was extremely embarrassed by the resolution of Francis I in letting it be known that he would resign the crown to his eldest son were his terms not accepted. For the kingdom and the government had survived intact without suffering revolution or alteration whatsoever as a result of the crisis. Although Spain, Italy, England, the Low Countries, the Pope, the Venetians, and all the Italian estates, were allied against the French house, none dared enter France to conquer her, knowing the strength other institutions and the nature of the monarchy.[7] As a strong building raised on sure foundations, constructed of durable materials and knit together in all its parts need not fear storms and tempests, nor violent assaults, so the commonwealth based on good laws and united together in all its parts does not easily fall a prey to revolution. There are however some so ill-founded and ill-united that the slightest wind destroys them. There is nevertheless no commonwealth which does not suffer transformation with the passage of time, and come to ruin eventually. But the transformation that is accomplished slowly is the most tolerable....

That Changes of Government and Changes in Law should not be Sudden [CHAPTER III][8]

... THE first condition that must be observed for the preservation of any commonwealth is that its specific type and the weaknesses to which it is prone, should be thoroughly understood. For this reason I pause here to consider such matters. It is not sufficient to have ideas as to which is the best type of commonwealth. One must also understand the means whereby each is preserved in its proper form, supposing it is not possible to modify it, or supposing any attempt to do so would threaten it with ruin. It is better to keep a sick man going by suitable diet 
than attempt to cure him of a malignant disease at the risk of his life. Violent remedies should never be employed unless the illness is critical, and no other expedients offer any hope. The same principles hold good in the commonwealth, not only regarding changes in the constitution, but also regarding changes in laws, manners, and customs. Lack of understanding of this principle has brought great and flourishing commonwealths to ruin, when the adoption of some admirable custom, borrowed from another state quite different in character, has been attempted. We have already shown that certain good laws which tend to the preservation of a monarchy would be the ruin of a popular state, while certain other laws which preserve the liberty of the people would bring about the downfall of a monarchy.

It is true that there are a number of rules which apply indifferently to all types of commonwealth. But the old problem, so often debated by political philosophers, still remains unresolved. Is the introduction of some new custom, which is an improvement on the old, to be encouraged, in view of the fact that no law, however good, has any force if it is not respected? But novelty always brings the law into disrepute. The binding force of habit is so strong that it secures obedience to the laws without the intervention of any magistrate, whereas new laws, even when backed up by the authority of the magistrate, and reinforced with pains and penalties, are established only with difficulty. It could therefore be argued that the benefit of a new law, however good, is outweighed by the fact that the whole general force of law is weakened once one begins to make changes. In short, there is nothing more difficult to undertake, more doubtful of success, or more dangerous in the attempt, than the introduction of new laws.

This argument seems to me to have considerable force. I would add another consideration which also seems to me of great weight. I think it extremely dangerous to make any change in the law touching the constitution. The amendment of laws and customs touching inheritances, contracts, or servitudes is on the whole permissible. But to touch the laws of the constitution is as dangerous as to undermine the foundations, or remove the comer-stone on which the whole weight of the building rests. Disturbed in this way, apart from the risk of collapse, a building often receives more damage than the advantage of new material 
is worth, especially if it is old and decaying. The same is true of an old-established commonwealth. The slightest disturbance of its foundations spells ruin. Therefore the ancient maxim of wise statesmen, that one should not tamper with the constitution of any commonwealth which has long maintained itself in good order for any advantage that can be imagined, should be weighed carefully. ...

If anyone objects that changes in the law are often necessary, especially in matters concerning the policing of a country, I agree that such necessity is prior to all rules about wisdom in legislation. But it is always dangerous to introduce laws and edicts which are a matter of choice, however good and profitable they may be, especially if they relate to the constitution. Not that I wish a commonwealth to cling to laws which no longer conduce to its preservation. One must always bear in mind the principle to which there is no exception, salus populi suprema lex esto. Thus Themistocles persuaded the Athenians to fortify the city with walls and fortresses, the better to defend it and secure their own safety. But Theremanes, for exactly the same reason, persuaded them to dismantle them, for otherwise the total rum of the people and of the commonwealth would have been certain. There are no laws, however excellent, which do not sooner or later change their value, and when necessity requires, they should be altered, but not before. Therefore when Solon published his laws, he made the people swear to keep them for the next hundred years, so Plutarch says. In doing this he showed that he did not wish that the laws should be regarded as unalterable, but that they should not be abandoned in any haste...

Even when the law is patently unjust, it is better to let it lapse gradually than to make any sudden change... Again, the nature of men is extraordinarily corruptible, and they continually descend from good to bad, and from bad to worse. Their vices slowly establish a hold on them, like the ill humours which gradually invade the body till they entirely possess it. It is therefore necessary at times to make new laws to deal with the situation, but it should always be done very gradually... The ordering of the commonwealth should be modelled on the ordering of the universe. God, the first cause, accomplishes all things gradually and almost insensibly. During the lifetime of the Doge Agostino Barbarino,[9] the Venetians did nothing to curtail his authority because 
of the disturbance it might cause. But after his death, and before proceeding to the election of Loredano, the Signory published new laws which drastically limited the powers of the Doge. We have shown how a similar policy was adopted at the election of the Emperors of Germany. From sovereign kings they were reduced step by step to the position of mere captains in chief. To make the change more palatable, they were left in possession of all the marks of imperial splendour in the vestments they wore, the style in which they were addressed, and in the ceremonies which surrounded them, but of very little else. Just as it is perilous to deprive a sovereign ruler suddenly of his authority, or a prince who has an armed force at his disposal, so it is no less dangerous for a prince to dismiss or rebuff abruptly the former officers of his predecessor, or suddenly to deprive a whole body of officials while retaining others. Those who are retained are suspected of jealous intrigues and those who are dismissed, of incompetence or dishonesty, besides being deprived of the charges which they have often enough bought dear. Perhaps one of the surest foundations of the French monarchy is that the officers of the crown retain their posts on the death of the king, and so are able to preserve the commonwealth intact.

This is not a danger which threatens popular or aristocratic states, since with them the sovereign never dies. But the risk is just as great when they have to appoint new high officers of state, or captains in chief; or when they have to initiate some law which is disagreeable to the people, because it favours the nobles and burdens the humbler citizens, or because there is a shortage of provisions, or because prices are too high. Such occasions always breed popular agitations and seditions.

Generally, when it is necessary to deprive magistrates, suppress guilds and colleges, cancel privileges, cut down salaries and benefices, increase penalties; or to restore the ancient usages in either politics or religion when they have deteriorated through the natural human propensity to corruption, there is no better way of achieving success than by gradual means. The use of force, such as is necessary if institutions are to be suppressed, is to be avoided wherever possible. We have a notable warning in the case of Charles V of France. When 
regent, he was misled by evil counsel into suspending or dismissing suddenly the majority of the officers of the realm, and replacing them by commissioners. France was immediately shaken by disorders from end to end, from the number of the malcontents[10] ... But when the Signory of Basel established the Reformed Church, it did not wish to expel immediately and forcibly all the inmates of abbeys and monasteries. It merely ordained that as they died no successors should take their place, whereby it happened that a single Carthusian continued to inhabit his convent for a great time all alone, all his fellow monks having voluntarily left. He was nevertheless never compelled to leave the place, nor abandon his habit or his profession....

I hold that the great increase in officials, in guilds, in privileged persons, or of evil-doers which has come about through the negligence of princes and magistrates ought to be checked in this way. The same principle holds good for all matters touching subjects as a whole, for it is rooted in the very nature of law, for law only really begins to take effect after some considerable passage of time.

Even in the case of tyranny, which is a thing cruel and detestable in itself, it is better if the tyrant has neither children nor near relatives, to defer bringing an end to the tyranny till after his death, rather than to use violent measures against the tyrant himself, and so expose the state to the risk of the ruin which so often befalls on such occasions. Only if the tyrant has heirs, and is employing himself, as is almost universal custom, in killing off all the people of any importance one by one, and in getting rid of any magistrates who might check him in his courses, in order to establish his own sole and unchallengeable authority, is it permissible to have recourse to violent measures, in accordance with the principles we laid down at the start; otherwise not. In governing a well-ordered state therefore one should follow the example of the workings of nature, by which all things are accomplished slowly, one step at a time. God causes a tall and spreading tree to spring from one small seed, but always by imperceptible degrees. He unites extremes by their mean, putting spring between winter and summer, and autumn between summer and winter, ordering all things according to His perfect wisdom And if it is dangerous to change laws easily, let us consider whether it is dangerous to change the officers of state at 
intervals, or whether they ought to be appointed permanently.

Whether the Tenure of Office in the Commonwealth should he Permanent [CHAPTER IV]

THEM is perhaps nothing that is more immediately a cause of revolutions in commonwealths than troubles arising out of the terms of office of the magistrates, either because they are too frequently changed, or because too indefinitely prolonged. The matter ought not therefore to be passed over without discussion, since it is a question of great political importance and worthy of careful investigation. I shall not attempt however to determine what should be done. I only intend to suggest those considerations that can persuade one way or the other, and leave the decision to those who have gone more deeply into the question. I do not do this however to encourage those who wish to introduce changes into those already established practices which all subjects ought to treat with great respect. Nor have I any desire to alter the forms of government which have developed in the course of many years. ...

It is to be noticed that even the wisest of those who have gone about to establish or perpetuate commonwealths, families, or other kinds of associations of men, have been liable to fall into two sorts of excess. The one is to be able to see the disadvantages only of any particular institution, without being able to weigh them against any corresponding advantages. The other is the tendency to rush from one disastrous extreme to the other, without being able to adopt any middle position, as it were to escape drowning only to perish by fire. Plato desired magistrates to be irremovable, that was one extreme. Aristotle, his pupil, avoided that error, saying it would light the fires of sedition in any commonwealth, but only to fall into the other extreme. Neither of them made any distinction between one commonwealth and another, yet this is fundamental to any resolution of the problem....

It is however obvious that commonwealths of a contrary tendency must be regulated in contrary ways. The institutions proper to the maintenance of popular states are the death of monarchies. Popular states are maintained by a continual replacement of officers, in order that each and all shall have that share in office proper to his station, since 
some share in sovereign power is due to all. Equality, the nurse of popular states, is best secured by annual succession in all magistracies, for the practice of long terms of authority is an encouragement to the ambitious to attempt to seize sovereign power for themselves. But in monarchies, when the subjects have no part in sovereignty, they should not be encouraged to entertain political ambitions; their whole duty consists in learning to obey their prince. This is especially the case in despotic and tyrannical monarchies. There the subjects are either the natural slaves of the despot, or the enforced slaves of the tyrant, and therefore neither the despot nor the tyrant can hope to hold his own if he gives authority to all his subjects successively.

For this reason tyrants, who no less fear and hate their subjects than they are feared and hated by them, and so can place no reliance on them, entrust the care of their persons, their position, their forces, and their goods to foreigners and those very few among their subjects whom they know to be true and faithful to them. These they keep in the same positions indefinitely, not only because they mistrust all others, but also because they do not wish to give any other persons such a taste of the sweets of power as to move them to consider ridding themselves of the tyrant, either from a desire to occupy his place, or to gain popularity.

The despot is obeyed rather more willingly by his subjects in that they are his natural, not his enforced slaves. He has therefore a freer hand in the choice of his officers than the tyrant, who is only obeyed through force and fear. He does not tend therefore to give offices in perpetuity, but at his own discretion, and for as long as he pleases, to such number of people as he thinks fit, without being subject to any rules or customs in the matter.

The king, who is to his subjects what a good father is to his children, though he is no more bound by positive laws than are the other two kinds of monarch, nevertheless does in fact lay down general rules governing the appointment and dismissal of officials with the intention of keeping them. Honours and offices will be distributed not to all indifferently, but to those who merit them. Experience and virtue will be more regarded 
than the influence of those who are most recommended. He will observe the golden mean in all things, some offices being perpetual, some terminable at the end of three years, others at the end of one, especially the chief members of the parlements, those responsible for finance, and governors of provinces. Otherwise these exalted persons could never be punished for misdemeanours or abuse of power. Offices and honours will be given to the rich and those of noble birth, even though they may not be as well-informed as less wealthy citizens, because it is a necessary precaution against sedition. But it will always be arranged that those exalted persons who are not really capable of discharging their functions properly shall have men well-versed in the business as their associates, to cover and remedy their defects. But should necessity arise the king is not bound to observe his own laws in the matter. He can deprive men of offices which by law are perpetual, should he judge that those who have been appointed are incapable in either mind or body of the office they hold; or to save the face of those who have proved incapable, he can give them some favourable opportunity of resigning their position, as Augustus did in the case of a number of senators who were induced to resign in this way without public action being taken; or he can at least appoint commissioners to execute the functions of any office, while leaving the holder with the title and the privileges.

In the interests of justice however always the principal foundation of any commonwealth, the king will provide that both criminal and civil jurisdiction shall be committed to colleges of judges in perpetuity, even for cases where there is no appeal. In this way he will secure judges skilled in their profession, partly from long experience in hearing cases, partly from constantly having to listen to the opinions of their colleagues. At the same time their numbers make them individually not very powerful, and therefore less able to abuse their trust, and more difficult to corrupt. It is not easy to contaminate a great volume of water. It often happens that a good and upright judge can carry a whole Bench with him, either by detecting the partiality and secret manoeuvres of dishonest judges, or, where they are honest but led astray by false witnesses and legal chicanery, by putting them wise to such practices. I have seen a single judge cause a whole Bench to change its mind and set free an innocent woman, cleared of all suspicion, whom 
the rest had decided to condemn to death as guilty. His name deserves to be recorded. It was the councillor Potier, lord of Blanc-Mesnil. ...

I have said that a king will neither make all office perpetual, nor all office temporary. There is no need to make such subordinates as clerks of the court, constables, ushers, notaries, and such like officers temporary. They have no independent authority and so can do no harm to the state, while the efficiency necessary to the proper discharge of their functions is the result of long practice in them. This is only possible if their appointments are permanent. The same may be said of subordinate magistrates whose sentences are subject to revision by their superiors. But if, in the case of sovereign magistrates, whether concerned with war, justice, or finance, the king only appoints them for the term of one, two, or three years, he has opportunities of examining their actions, and doing justice upon them. Incidentally, the dread of an enquiry keeps dishonest magistrates in check. But sudden and complete change is dangerous, and in order to avoid replacing all the officers of the realm at the same time, to the interrupting of public business, it is best that colleges of magistrates should be renewed by succession of persons, one at a time. This is done in the Republic of Ragusa, where the Senate is perpetual, but the senators, who form the sovereign judicial body, only hold office for one year at a time, but do not all go out of office together, but successively, so that the change is hardly noticeable. After a certain period they may serve again. ...

Such measures obviate the difficulties which arise with the interruption of public business caused by a simultaneous change of all the chief officers of state, and avoid the danger of the commonwealth being left without magistrates, like a ship without a pilot. This sort of thing frequently occurred in Rome, through the intrigues of magistrates who thwarted one another, and all came into office and went out at the same time. These arrangements also remove all fear that those who attain to the highest positions of trust in the state by bribery and by favour will remain inaccessible to punishment, or that ignorant men will continuously monopolize power, for after a short interval those who have already held office, and acquired experience, can be reappointed....

Yet ill-advised princes repeatedly abandon a good custom because of some 
defect they find in it. I need only give the one example of Louis XI. When he came to the throne, he immediately dismissed all the former servants of his father. They managed things in such a fashion thereafter as to bring him almost to the point of resigning or losing his crown, as he afterwards confessed. Fearing that his son would fall into the same error, he charged him never to deprive those whom he himself had advanced. Not content with this, he promulgated an ordinance making all office perpetual; once appointed, the holders could not be deprived except as a result of resignation, death, or forfeiture....

What we have said about the moderation which ought to be observed in the rules governing the appointment of magistrates, and the prolongation of their charges, applies not only to monarchies, but to aristocracies and popular states. In such states practically all offices are held for the term of one, two, or three years, as one may see in the Swiss and other republics. Nevertheless it is necessary for their conservation that there should be some permanent bodies, especially for the discharge of those matters which require wisdom and experience, for instance, giving counsel. We find therefore that in Rome, Athens, and Sparta the senate was perpetual, and senators continued in office as long as they wished to serve. Thus the senate of Athens and the other republics resembled the hinges and pivots on which great weights revolve. It was fixed and stable, and all the movable offices, and the whole state of republic rested on it. The opposite is the case with monarchies. There practically all offices are perpetual, save a few of the principal and most responsible ones. The Spanish monarchy has best understood how to keep the middle way proper to monarchical states. For the same reason the Venetians whose republic is an aristocracy, make all their appointments for one year only, and some for only two months. But the Doge, the Procurators of St. Mark, the Chancellor, and the Secretaries of State are permanent officials. The Florentines adopted the same expedient. After Louis XII had freed them from the tyrannical designs of the Count Valentino they too set up a permanent chief magistrate, so that the Republic, perpetually subject to rapid changes in all offices and magistracies, should have some stable foundation on which to rely.[11] But the ordinances being shortly after annulled, they fell into civil strife more immediately than they had ever done before. If they had had at least a perpetual senate, and the senators had remained 
in office instead of being replaced every six months, and if they could have found some mean between the extremes of universal change and universal permanence in all offices, their government would have been secure instead of being disturbed by continual conspiracies and civil commotions.

Whether the Prince should render justice to his Subjects in Person[12] [CHAPTER VI][13]

SOME readers may think that this is a question about which no discussion is necessary, seeing that all the ancients, and all discriminating students of politics are agreed that kings were first established for no other reason that to do justice, as Herodotus shows of the Medes and Cicero of the Romans ... The chief consideration that should move princes to do justice is the mutual bond between them and their subjects, whereby the subject owes obedience and assistance to his lord, and the prince owes justice, care, and protection to his subject. He does not discharge this obligation by appointing a representative to act in his name. For just as the subject is bound to swear allegiance in person, and to render homage and service himself, so there is a reciprocal obligation on the prince. Indeed, it is not so serious if the vassal swears allegiance and homage by proxy as if the prince does justice only through his officers. The obedience due from the subject is not thereby called in question. But the subject on his side has no guarantee that the prince's officers will not be corrupt. The prince is responsible before God, and the obligation on his conscience to see that justice is done is not discharged by his mere instruction to judges to see to it.

Moreover it is of the greatest importance for the preservation of the commonwealth that whoever exercises sovereign power should himself dispense justice. Union and mutual amity between a prince and his subjects is best fostered by mutual intercourse. This advantage is lost if the prince acts only through his officers. Subjects always imagine themselves despised and neglected by officials, a suspicion more serious in its results than if they experience actual injustice at the prince's hands, for contempt is harder to endure than a straightforward injury. But when subjects see their prince giving judgement in person, they are 
by this mere fact already half satisfied, even though he does not thereupon grant their requests. They reflect that at any rate the king has attended to their petition, heard their complaints, and taken pains to judge the matter. It is extraordinary how uplifted and delighted subjects are to be seen, heard, and attended to by a prince even of very modest virtues, or of some mild degree of amiability. Moreover nothing gives greater authority to magistrates and subordinate officials, or excites more fear, and reverence for justice, than the sight of the king enthroned for judgement... In fine, it cannot be doubted that the prince in doing justice constantly upon his subjects accustoms himself to be in his own person just, upright, and true. Seeing that this is the greatest boon that can fall to the lot of any commonwealth, should not one desire constantly and ardently that the prince should be ceaselessly employed in giving judgement? The true function of the prince is to judge his people. He must of course also be armed against the enemy, but justice is his necessary attribute in all places, and at all times.

But the example of wise princes is of more weight than reasons and arguments. Was there ever a prince the equal of Solomon for wisdom? We read that his sole prayer to God was for wisdom so that he might judge his people aright, and his judgements were reported throughout the world, to the wonder and edification of all peoples. Who was ever the equal of the great Augustus for political prudence? We read of him that he was incessantly employed in giving judgement? He would not let even illness prevent him from being carried into the court. Such was the ordinary and daily function of the Roman Emperors and they won thereby a reputation for justice above all other princes of the world. ...

Nevertheless I do not think these arguments are of sufficient weight to settle the question and prove conclusively that the prince should dispense justice in person. It is true this would be expedient and even necessary if princes were, as Scylax said of those in the Indies, as superior to their subjects as God is high above mankind. There is nothing finer or more royal than the spectacle of a prince performing exploits of virtue in the presence of his people, and out of his own mouth rebuking and condemning wicked men, praising and rewarding the good, publicly taking counsel of the wise, and engaging in weighty debate. Only a man who is himself upright esteems virtuous company and 
hates evil men, and only a prince who is himself just and true can dispense impartial justice.

But should we agree that vicious princes ought also to live in the public eye, and thereby communicate their vices to their subjects?

The least vice in a prince defaces his fair image, and cannot but have the effect of attracting, persuading, or even compelling his subjects to evil. It is the most natural thing in the world for subjects to model themselves on the manners, the behaviour, and the conversation of their prince. No gesture, action, or expression of his escapes the notice of those who observe him with the closest attention with a view to imitation ... We have seen how, when Francis I, King of France, and Mansur called the Great, Emperor of A frica and Spain, each in their several times and places began to patronize learning, immediately the princes, the nobles, the clergy, and common people devoted themselves with such ardour to the sciences, that never was such a concourse of men learned in all languages and sciences seen as in their time. Since princes then are a model to their subjects, let them be as perfect as in them lies, and if they fall short in this respect, let them not make public appearances.

It may be objected that this is not a good enough reason why a prince should live retired, and not appear to judge and communicate directly with his people, since they have the wits, which they should employ, to judge of his actions, and follow the good and eschew the evil. But I would answer that it is much easier to imitate vice than virtue, for men are naturally inclined more to evil than good, and whereas there is only one straight and narrow way that leads to virtue, there are a hundred thousand side paths that lead to vice ... Such power has a faulty prince of transforming and turning the hearts of his subjects according to his own good pleasure. He has even greater power of turning them to folly. I can give another example from the conduct of King Francis. He once shaved his scalp in order to assist his recovery from a wound in the head. Immediately first his court, and then everyone else shaved too, so that from that time long hair which was once a mark of beauty and privilege of nobility became an object of ridicule... 
Suppose however we grant that the prince is neither inept, ridiculous or vicious, but virtuous and well-conducted, the fact remains that daily communication and a too great familiarity with his subjects engenders a certain contempt for the sovereign. Contempt of him leads to disobedience to his commands and his laws, and disobedience spells the ruin of the state. On the other hand, if the prince makes a habit of appearing in public, but always in great state and in the guise of a severe and terrible judge, it is true that he may inspire his subjects with respect, but he will also run the risk of losing their love. Love of the subject for his sovereign is much more conducive to the preservation of the state than fear, for love always has an element of fear in it, the fear of offending the object of one's love. But fear by itself can be, and mostly is, devoid of any admixture of love. Almighty God, the ruler of the whole world, made manifest what relations earthly princes, who are his true images, ought to have with their subjects. For God only communicated with men in dreams and visions, or through the very small body of the elect, and the greatest saints. When He declared the decalogue in His own voice, divine fire filled the heavens, and thunder like the terrible sound of trumpets shook the mountains, so that the people threw themselves upon their faces, praying Him to cease speaking lest they should die. It is written that He caused them to hear His voice that they might for ever after tremble to offend Him.

Nevertheless He moved them to love Him by blessing them with manifold and great favours and bounties. The wise prince who imitates in the management of his subjects the wisdom of God in governing the world will show himself little to his subjects, and then in solemn state as befits his high authority. He should moreover choose men of great worth, such as are not easily found, to make known his will. For the rest, he should constantly bestow his graces and favours on all his subjects...

But granted that the prince has wisdom, understanding, prudence, discretion, experience, patience, and all the virtues, it is still of doubtful advantage for him to judge his subjects in person. The best means of preserving the authority of the monarchy is that the prince should be loved by all, without any alloy of contempt, and as far as possible hated by none. To achieve this two things are necessary. First, just punishments must be meted out to malefactors, and rewards to the worthy. But seeing that whereas the latter is a pleasing task, and the 
former is invidious, the prince who wishes to command the affection of his subjects should reserve to himself the distribution of rewards, whether estates, honours, offices, benefices, pensions, privileges and concessions, grants of immunity, exemptions, and restitutions, and all such graces and favours. Any prudent prince should bestow such himself. But for condemnations, fines, confiscations, and all like penalties, let him delegate their infliction to his officers, for them to administer good and expeditious justice. If he manages his affairs in this way, those who have received benefits at his hands are constrained to love, respect, and honour their benefactor; those who have been punished will have no occasion to hate him, but will vent their anger on their judges. The prince, showering benefits on all, but injuries on none will be welcome to all and hated of none. Nature has provided us with a model in the king of the bees, who has no sting ... I myself think that one of the admirable secrets of the long success of this monarchy is the wise practice of our kings, since earliest times, of themselves distributing graces and favours, while delegating the duty of punishment, without respect of persons, to their officers. ...

What I have said about the inadvisability of the prince assuming the role of judge has even more force in popular states, because of the great difficulty of assembling the people, of making them listen to reason when they are assembled, and having listened, to pass sound judgement. Such difficulties were the greatest single cause of civil wars among the Romans until the dictator Sulla vested the cognizance of all causes, save treason in the first degree, in the magistrates. Moreover the denial of the exercise of their ordinary and legitimate powers to the senate and the magistrates, in order to attribute them to those in whom sovereign power is vested, has been a most frequent cause of the ruin of commonwealths. The true attributes of sovereignty apart, the more powers a sovereign has, the less secure he is... Perhaps the thing that has most conduced to the preservation of the Venetian state is that there has never been a republic in which those in whom sovereign power was vested interfered less with the business of the council and the magistrates. The Great Council hardly concerned itself with anything save the appointment of magistrates, the issue of general ordinances, and the granting of graces, which are, of course, the principal attributes of sovereignty. All other affairs of state were attended to 
by the Senate, or the Council of Ten, and the administration of justice by the magistrates.

If this is well-ordered and praiseworthy in an aristocracy, it is even more desirable in a popular state, for the more heads, the less counsel, and the less resolution ... We read that the Roman Republic was never more flourishing than at the time when the people did not concern them selves with any exercise of power save their rights of sovereignty. This was the period from the first Punic war till the conquest of the kingdom of Macedon. But once the Tribune Caius Gracchus curtailed the powers of the Senate and the magistrates in order to make the people cognizant of matters of all sorts, nothing but seditions, assassinations and civil wars followed, till this outrageous licence of the people was exchanged for an extreme servitude. ...

A state cannot fail to prosper where the sovereign retains those rights proper to his majesty, the senate preserves its authority, the magistrates exercise their legitimate powers, and justice runs its ordinary course. Otherwise, if those who have sovereign power attempt to invade the sphere of the senate or the magistrate, they only risk the loss of their own authority. They are much mistaken who think to exalt the sovereign by making him aware of his claws, and impress on him that his will, his very glance, has the force of an edict or a judgement, so that none of his subjects can take cognizance of any matter which may not be revised or reversed by him. This engenders an insupportable arrogance and tyranny in the prince. ...

How Seditions may be Avoided [CHAPTER VII]

...WE put first as a general maxim that factions and parties are dangerous, and threaten the well-being, of all kinds of commonwealths. They must therefore be prevented wherever possible by wise counsel, and if only discovered after they have been set on foot, every means should be taken to cure them, or at the worst, nothing should be omitted which is likely to mitigate the evil. I would not deny that factions and seditions bring in their train great benefits, such as some wise law, or beneficial reform, which would hardly have come about without agitation. But this does not disprove the fact that sedition is in itself 
dangerous, for its good results are purely fortuitous and accidental... Seditions often lead to the death or banishment of evil men, which allows the rest to live thereafter in peace. Or unjust laws and ordinances may be abolished, and replaced by just ones which otherwise would not have been accepted ... But just as diseases are pernicious to the body, so conspiracy and conjuration is pernicious to the commonwealth.

Someone may say that factions are necessary to the preservation of tyrants, since they are inevitably the enemies of their subjects, and could not long maintain themselves in the face of a united people. We have already shown that tyranny is the weakest of all forms of the commonwealth, since it is upheld by cruel and wicked deeds. Nevertheless tyrannies are generally brought to an end by sedition or civil war. Even the most ingenious of tyrants, who have committed their murders one at a time, growing fat on the life-blood of their subjects, and preserved their own miserable lives, though dragged out in terror and despair, have not escaped the knife of the conspirator. The more subjects they put to death, the more are conspiracies against them nourished by the avengers of murdered kindred. Even should whole families be exterminated, in the end all good men and true rise against them ... Therefore the Florentines were mistaken in thinking that their authority in Pistoia was the better secured by nourishing factions among its inhabitants. They only lost influence by the death of good citizens destroyed in civil strife.[14]

But if factions and seditions are dangerous to monarchies, they are even more so to popular states and to aristocracies. Monarchs can preserve their authority, either by impartially composing quarrels, or in alliance with one of the parties by bringing the other to reason, or by destroying it altogether. But if the people in a popular state are divided, there is no sovereign to appeal to, any more than there is when the governing class in an aristocracy splits up into cliques. ...

If it is obvious that the opposing factions cannot be dealt with by process of law, the sovereign ought to resort to force to extinguish them altogether, by the punishment of the manifest leaders before they have become so strong that there is no prevailing against them ... The 
punishment of a few may then induce the rest to remember their allegiance, and discourage those who have not yet openly joined in. The prince should avoid however mass executions, or the torturing of suspects....

In the case of factions and conjurations which are not directed against the prince personally, nor against his government, but divide the nobles, or the towns, or the provinces subject to him from each other, he ought by all means in his power to stop them developing. He should not omit the smallest precaution. Great storms and tempests are bred from almost imperceptible mists and vapours, and civil wars can originate in the most trivial circumstances. ...

Just as it is easier to prevent an invasion than to expel the enemy once he has effected an entry, so it is better to prevent sedition than to try and cure it. This is even more difficult in a popular state than in any other. The prince in a monarchy, and the governing class in an aristocracy are, and ought to be, the sovereign judges and arbiters of the quarrels of their subjects. Often enough their absolute authority is sufficient to put an end to conflicts. But in a popular state sovereignty is vested in the very people who are divided, and the magistrates are nothing more than their subjects.

There is need then for wise statesmen to come to terms with the people in such a case, and to humour them in order to bring them to reason. The lunatic who cannot stop dancing and singing incessantly cannot be calmed unless the musician first attunes his violin to the patient's mood, and then gradually modifies the rhythm till he has cured him. So the prudent magistrate, faced with an excited people, at first gives way to their temper in order to be able to bring them to reason by gradual means. To resist an exasperated multitude is no more possible than to oppose oneself to a torrent dashing down from some great height. It is even more dangerous to resort to force against one's subjects, unless one is absolutely certain of victory. If the subject is victor, he will most certainly displace the vanquished. Even if the prince is not vanquished, but merely fails of his objective, he renders himself contemptible, and encourages other of his subjects to revolt, foreigners to attack him, and all to despise him. The danger is greatest in popular states. It is 
evident in all the seditions that vexed Rome, that those who wished to proceed by force, and openly resist the wishes of an angry people ruined all, but those who proceeded mildly and cautiously brought the people to reason. One must humour the people, and make some concession to them, even an illicit one. But let it be understood that this is only when they are in a rebellious mood. It is not meant that one should always pander to the passions, but hold them in check rather. ...

But should the sovereign prince take sides, he abdicates his role of sovereign judge and becomes merely party leader. He thereby puts his life in hazard, even if the revolt is not specifically directed against his authority. We have seen this in the wars of religion which have ravaged Europe for the past fifty years. We have seen the kingdoms of Sweden, Scotland, Denmark, and England, the Swiss Confederates and the Empire of Germany all change their religion, though the commonwealth preserved its republican or monarchical form unaltered in each case. In many places this has not been accomplished without much violence and shedding of blood. But once a form of religion is accepted by common consent, further disputation should on no account be admitted. All questions which are made matters of debate become thereby matters of doubt. But it is a great impiety to make a matter of doubt of the thing which each man should be certain about and hold to resolutely. But there is no matter, however simple and true, which is not made confused and obscure by dispute, especially any matter which does not depend on reason and demonstration, but on belief simply. If philosophers and mathematicians do not question the principles of their sciences, why should one be permitted to question a religion which has once been accepted and approved ... It is well known that the kings of the East and of Africa strictly forbid any discussion of religion. The same prohibition is contained in the Ordinances of Spain, and of those of the King of Muscovy. The latter, seeing his people divided into sects and factions in consequence of the disputatious sermons of ministers of religion, forbad preaching, or even discussion of religion on pain of death. Priests were provided with a written creed and exhortations to be read to the faithful without comment or addition, on the festivals of the Church. By the law of God it is expressly commanded that the Scriptures should be read constantly to people of all ages and both sexes. It is not said that they should be discussed. On the contrary, 
the Hebrews, taught by the Prophets from father to son, expounded the law of God in the seven colleges on Mt. Sion, but they never disputed, as we read in Optatus Milevitanus. The disputation was devised to investigate matters of probability, and not matters necessary and divine, since the latter are always rendered doubtful, being the subject of disputation. Therefore all discussion of religion was strictly forbidden on pain of death, and the prohibition rigorously enforced in certain German towns, after the Imperial Diet of 1555.[15]

Even atheists agree that nothing so tends to the preservation of commonwealths as religion, since it is the force that at once secures the authority of kings and governors, the execution of the laws, the obedience of subjects, reverence for the magistrates, fear of ill-doing, and knits each and all in the bonds of friendship. Great care must be taken that so sacred a thing should not be brought into doubt or contempt by dispute, for such entails the ruin of the commonwealth.

I am not concerned here with what form of religion is the best. (There is in fact only one religion, one truth, one divine law proceeding from the mouth of God himself.) But if the prince who has assurance of the true religion wishes to convert his subjects, split by sects and factions, he should not, in my opinion, attempt to coerce them. The more one tries to constrain men's wills, the more obstinate they become. But if the prince in his own person follows the true religion without hypocrisy or deceit, without any use of force, or any infliction of punishments, he may turn his subjects' hearts. In doing this, not only does he escape unrest, trouble, and civil strife, but he guides his errant subjects to the gates of salvation....

The King of the Turks, who rules over a great part of Europe, safeguards the rites of religion as well as any prince in this world. Yet he constrains no one, but on the contrary permits everyone to live according as his conscience dictates. What is more, even in his seraglio at Pera he permits the practice of four diverse religions, that of the Jews, the Christian according to the Roman rite, and according to the Greek rite, and that of Islam. He also sends alms to the good fathers or Christian monks of Mount Athos, in order that they shall pray for him. Augustus did likewise with the Jews, sending the usual alms and 
oblations to Jerusalem. Although Theodoric, King of the Goths, favoured the Arian sect, he did not force the consciences of his subjects, giving as his reason, according to Cassiodorus, that he could not command in matters of religion, since no one can be forced to believe against his will.

If a prince does otherwise, those who are prevented from the exercise of their own religion, and not in sympathy with any other, end by becoming atheists, as we know. Once they have lost the fear of God, they trample under foot the law and the magistrate, and give themselves over to every sort of impiety and wickedness, beyond the power of any human laws to remedy. And just as the cruellest tyranny does not make for so much wretchedness as anarchy, when neither prince nor magistrate is recognized, so the most fantastic superstition in the world is not nearly so detestable as atheism. One must therefore avoid the greater evil if one cannot establish the true religion....

We have spoken of the causes leading to changes in the form of governments and of commonwealths. The same causes give rise to unrest and civil war; that is to say failure to do justice, oppression of the poor and humble, the unfair distribution of punishments and honours, excessive riches in a few and excessive poverty in the rest, idleness in the subject, and impunity in ill doing. This last is of the greatest importance, though it is mostly considered the least. I have already said this, but it bears frequent repetition. In proportion as princes and magistrates try to win a reputation for mercy, so they call down on their own heads the penalties that evil-doers have merited....

But besides these causes of unrest there is another which proceeds from the freedom which is allowed to orators, who play upon the emotions and fan the desires of the people as they choose. There is nothing which has greater influence over men's souls than the art of eloquent speech. Our forefathers portrayed the Celtic Hercules as an old man, trailing after him a crowd of people fastened by the ears with chains issuing from his mouth. They thus intimated that the powers and armed forces of kings and princes are not so potent as the vehemence of an ardent and eloquent man. He can excite the most cowardly to overcome the bravest, he makes the proudest cast aside their arms, turns cruelty into gentleness, 
barbarity into humanity, revolutionizes a commonwealth, and plays upon the people at will. I don't say all this in praise of eloquence, but to show what force it has, for it is a force more often used for ill than good ends. It is nothing more than the art of disguising the truth, an artifice to make that which is evil seem good, that which is right, wrong, make a mountain out of a molehill and an elephant out of a mouse. In other words it is the art of successful lying. There is no doubt that for one who makes a good use of this art, fifty abuse it ... There is no need to prove this by examples from Greece and Rome, one can see it in our own age ... John of Leyden, who was a cobbler turned preacher, seized Münster, the capital city of Westphalia, caused himself to be crowned its sovereign king, and sustained a seige by the imperial army for three years. The preacher Geronimo Savonarola, supported by Pagolantonio Soderini, moved the people to choose a popular form of state when it was in doubt whether Florence should become an aristocracy or a popular state. In the same way Pericles employed the orator Ephialtes to persuade the Athenians to a popular state of an extreme type. In brief, we have seen all Germany in arms, and a hundred thousand people killed in less than a year because unruly preachers incited the people against the nobles....[16]

Nevertheless, for those who wish to make good use of this weapon, it is a means of converting a people from barbarism to humanity, it is a means of reforming manners, improving the laws, expelling tyrants, banishing vice, and strengthening virtue. There is no better means of appeasing discontent, and persuading subjects to obedience than to employ a good preacher, for he will find a way to soften and turn the hearts of the most obstinate rebels. This is especially true in a popular state where an ignorant people is master, and cannot be restrained except by orators. For that reason they have always enjoyed the highest degree of honour and power in popular states, controlling the distributions of offices and charges, gifts and honours according to their good pleasure. In brief, the issues of peace and war, arms and laws hang upon the words of orators. On the other hand there is nothing that the tyrant has to fear more than a popular orator, if his tyranny is hated.

But since these rules which we have formulated should be adapted to the nature of the commonwealth and the type of government, laws, and customs 
to the nature of each particular people, let us consider the nature of the various peoples as a matter most necessary to be understood for the good government of commonwealths.

1. Paolo Manuzio was the son of Aldo Manuzio and carried on the work of the Aldine Press after him. I cannot find that he composed any work on Venice. But his son, Aldo Manuzio il Giovane, who was associated with him in the work of editing and publishing, wrote a book Discorso intorno all' excellenza delle repubbliche, published in 1575. I have not been able to consult it, but possibly the two men were confused by Bodin.

2. In 1524, 12 years after the death of Pandolfo Petrucci, virtual despot of Siena, there was a rising against his son, and a government of all sections established. In 1525, after Pavia, there were further disturbances when the city put itself under the protection of the Emperor Charles $\mathrm{V}$ on payment of a tribute. The extreme republican party restored order, and confirmed the agreement with the Emperor, whereupon a number of their aristocratic opponents withdrew from the city.

3. A Medici who governed Florence through the Cardinal Passerini. Hence the outbreak against the regime when the Pope became a prisoner in Castel Sant' Angelo in 1527 when Rome was sacked by the Imperial army under the Constable de Bourbon.

\section{Duke Cosimo I de' Medici, 1537-74.}

5. He supported Savonarola and the popular party against the aristocrats, and was set upon and killed by his enemies when Savonarola fell.

6. Venetian admiral commanding in the wars of the early fourteenth century, victor over the Turks at Gallipoli in 1416, over the Genoese at Rapallo in 1431, and defender of Constantinople 1421-24.

7. Bodin is referring to the situation of France after Pavia, when the King was captive and the alliance between Pope and Emperor brought a 
general alignment against her.

8. Chapter II is devoted to a discussion of the predictability of political changes. It is almost entirely astrological. The conclusion is very fairly summed up at the beginning of chapter III. 'Though the principles of astrology are generally accepted, and proved by experience, the influence of the stars does not imply an order of necessity. God has given men wisdom and understanding, whereby they may preserve the good order of commonwealths, and forestall the ruin they foresee.'

9. Agostino Barberigo was Doge from 1486 to 1501 . He was suspected of corrupt practices, but an enquiry was deferred till after his death.

10. In 1357 while King John was a prisoner in England, the Estates-General, angry at heavy taxation and the disastrous course of the war, and suspicious of misgovernment, forced upon the Dauphin Charles, as regent, a council of 36 reformer-generals with wide powers of correction. One of its first acts was to suspend all officers of Justice and finance, pending an enquiry into their conduct. The consequent anarchy brought its own reaction, and assisted Charles in getting rid of the Estates and re-establishing the authority of the Crown.

11. The Count Valentino was Cesare Borgia. Louis XII intervened on behalf of the Republic to check his conquests in Tuscany. The office referred to, that of Gonfaloniere a vita was instituted in 1502, but its holder, Piero Soderini, was forced to resign when the Medici, with the support of Spanish arms, re-entered the city in 1512 .

12. This question was not entirely academic in Bodin's day. Louis XII still attended and heard cases in the Parlement of Paris. The practice however was discontinued after his death. However Henry III could still promise in the Ordinance of Blois, 1579 , to render justice personally to such of his subjects as sought it, but by then such action no longer corresponded with the facts.

13. Chapter V is devoted to considering whether magistrates ought to be 
unanimous or divided in their opinions and policies. The general conclusion is that division is mischievous in popular and aristocratic states, but not very dangerous in a monarchy where the king can hold the balance.

14. Pistoia was a subject city to Florence. Its inhabitants were divided into the factions of the Panciatichi and the Cancellieri. Their rivalries prevented any united resistance to Florentine domination, but assumed such proportions that from 1500 to 1502 it was not possible to exercise any control in the city, till some sort of a compromise was negotiated by the Florentine government.

15. The Diet of Augsburg, which finally permitted Princes of the Empire to establish Lutheran forms of worship in their principalities, if they thought fit.

16. A reference to the Peasants' Revolt of 1524-25.

\section{BOOK V}

The Order to be observed in adapting the Form of the Commonwealth to Divers Conditions of Men, and the means of determining their Dispositions. [CHAPTER I]

So far in discussing the commonwealth we have been concerned with general principles. It remains to discuss the particular characteristics of the different sorts of commonwealth that the diversity of races requires. Political institutions must be adapted to environment, and human laws to natural laws. Those who have failed to do this, and have tried to make nature obey their laws, have brought disorder, and even ruin, on great states. One observes very great differences in the species of animals proper to different regions, and even noticeable variations in animals of the same species. Similarly, there are as many types of men as there are distinct localities. Under the same climatic conditions oriental types are different from occidental, and in latitudes at equal distances from the equator, the people of the 
northern hemisphere are different from those of the south. What is more, when the climate, latitude, and longitude is the same, one can observe variations between those who are mountaineers, and those who live on the open plains. Even in the same city there is a difference in humour and in habits between those who live in the upper and those who live in the lower parts of the town. This is why cities built in hilly country are more subject to disorders and revolutions than those situated on level ground. Rome, built on seven hills, was hardly ever free from civil commotions ... The Swiss, a people that came originally from Sweden, afford another example, for they are of the most various temperaments, dispositions, and forms of government. Though they are more closely related one to another than any other people, the men of the five Forest Cantons and the Grisons are the more proud and warlike, and prefer an extreme form of popular government. The others are more tractable, and they are governed by aristocracies, for they are by nature more inclined to that form of government than to a popular one....

A wise ruler of any people must therefore have a thorough understanding of their disposition and natural inclinations before he attempts any change in the constitution or the laws. One of the greatest, if not the principal, foundation of the commonwealth is the suitability of its government to the nature of the people, and of its laws and ordinances to the requirements of time, place, and persons. For although Baldus says that reason and natural equity are not conditioned by time and place, one must distinguish between universal principles, and those particular adaptations that differences of places and persons require. The governments of commonwealths must be diversified according to the diversities of their situations. The ruler must emulate the good architect who builds with the materials locally available. The wise statesman must do this too, for he cannot choose such subjects as he would wish.

Let us then first consider the nature of northern peoples, and southern, then of eastern and western, and the difference between those who inhabit mountainous country, and those who live on flat plains, or in marshy districts, or who are exposed to perpetual strong winds. We will then consider how the discipline of laws can modify the natural disposition of men, for we reject the doctrine of Polybius and Galen 
that their natural environment has an absolute and necessary effect in forming men's morals. Furthermore, in order the better to distinguish the very great differences there are between those who live in the north and those who live in the south, we propose to divide all those who live this side the equator into three sections. The first are those who live between the equator and the thirtieth parallel. This is the torrid zone, and its inhabitants southerners. The next thirty degrees, to the sixtieth parallel, is the temperate zone, and its people therefore occupy a middle situation. From the sixtieth parallel to the pole is the frigid zone, inhabited by northerners. The same divisions can be applied to the people in the southern hemisphere, between the equator and the antarctic pole ... The climate between the sixtieth and the seventy-fifth parallel is severely cold, but there are nevertheless people living there, and a number of commonwealths. But one can have little to say about the last fifteen degrees below the pole, for there are no men there, or only very few, and those savage creatures who live like beasts in caves, so traders tell us, and what they say is confirmed by our histories. ...

Just as in winter, places underground, and the internal organs of animals, conserve the heat that is dissipated in summer, so people inhabiting the northern latitudes have a more vehement internal heat than those living in southern latitudes. This internal heat gives them much greater strength and natural vigour than have the rest. The coldness of the climate, by conserving their natural heat, gives them a greater appetite, and they eat and drink more than others. In consequence when armies drawn from the more southerly regions invade the frigid zone, they become more vigorous and bold. This was evident when Hannibal's army invaded Italy, or when the Arabs and the Moors invaded Spain, or in the case of the seven thousand Spaniards the Emperor Charles V took to Germany.[1] They all won notable victories. On the other hand northern troops lose their vigour and become dispirited when they are transported into southern countries, especially if it be in summer. The Cimbrians were an example. Plutarch says that the heat they had to endure in Provence completely exhausted them by keeping them in a perpetual sweat. Had not the Romans vanquished them first they would almost certainly have died. The same fate overtook the French before Naples,[2] and the lanzknechts who were led into Italy by Charles of 
Bourbon and George Fronsberg.[3] After they had sacked Rome, before the year was out, ten thousand of them had perished without a blow struck, according to Guicdardini.[4] The same effects are to be observed in cattle that are transported from the north to some southern country. They lose their fat, fail to give milk, and suffer a general decline. Pliny remarked on it, and traders are always experiencing the same thing. A Spaniard doubles his energy and his appetite when he goes into France, while a Frenchman in Spain becomes languid and dainty. If he tries to go on eating as he was accustomed to do at home, he runs the risk of putting a term to his existence. Northerners feel languid when a south wind blows. For the same reason men and animals, and especially birds, who are very sensitive to change, grow fat in winter and thin in summer.

If Leo Africanus[5] and Francesco d'Alvarez,[6] the authors of histories of Africa and of Ethiopia, had observed the working of these natural causes, they would not have praised the abstinence of the people of these regions so highly. They cannot have much appetite if they lack internal heat. For the same reason one should not blame northerners for their gross appetites, and for eating more voraciously than southerners; it is a consequence of the heat, the size and the bulk of their bodies. The same effects may be found in antarctic regions. We read in the History of the Indies[7] that Magellan found in those territories which were named after him, Patagonian giants, so large and so powerful that eight armed Spaniards were hardly sufficient to hold their own against one of these simple and stupid people.

Northerners succeed by means of force, southerners by means of finesse, people of the middle regions by a measure of both. They are therefore the most apt for war, in the opinion of Vegetius and Vitruvius. It is they who have founded all the great empires which have flourished in arms and in laws. God has so distributed His favours that great strength and great cunning are never allied either in men or in beasts, for there is nothing more cruel than injustice armed with force. People of the middle regions have more physical energy but less cunning than southerners, and more intelligence but less strength than northerners. They are better fitted to command, and to govern commonwealths, and they are more just in their conduct. If one reads the histories of these 
various peoples attentively, one will find that great and powerful armies have always been raised in the north, while the occult sciences, philosophy, mathematics, and other pure sciences are the achievement of southern races. But political sciences, law, jurisprudence, rhetoric, and logic originated among the people of the middle regions. These people have established all the great empires the world has known, that of the Assyrians, the Medes, the Persians, the Parthians, the Greeks, the Romans, the Celts. Though the Arabs and the Moors for a time conquered the empire of Persia, Syria, Egypt, and Barbary, and subjected a great part of Spain, they could never subject Greece or Italy, and when they tried to subject France they were defeated, and an army of three hundred thousand men routed. The Romans extended their empire over the peoples of the south and east. But they had only moderate success against those of the west and north, though victors over all other peoples. Nevertheless they applied all their resources and made the greatest efforts to parry the blows delivered by those northern races who had, as Tacitus says, speaking of the Germans, neither walls, towns, nor fortifications. Although Trajan constructed a great bridge over the Danube and defeated Decebalus, King of the Dacians, his successor the Emperor Adrian caused it to be demolished, being afraid that the northern barbarians would destroy the empire and the power of the Romans. This they did after Constantine had disbanded the Roman legions that held the frontiers of the Rhine and the Danube. Thereafter first the Germans, then the Goths, Ostrogoths, Vandals, Franks, Burgundians, Herules, Hungarians, Gepidae, Lombards and finally the Normans, the Tartars, and the Turks overran the provinces that the Romans had once held. Though the English have w on notable victories over the French, in nine hundred years they have not been able to expel the Scots from the island, although one knows how much more numerous the French are than the English, and the English than the Scots....

In my opinion Aristotle was mistaken in thinking that people who lived either in extremely cold or extremely hot climates were barbarous. On the contrary their histories, and experience shows that people who live in the extreme south are much more ingenious than those of the middle regions. Herodotus has left it on record that the Egyptians were the most subtle and ingenious people in the world. Seven hundred years later Caesar in his history of the civil wars made the same judgement on them 
... Without looking further afield, we have the same point illustrated in the difference in intelligence between the French and the English. The latter complained to Philippe de Comines that to their surprise the French generally lost the battles they fought against them, but recovered their advantage in the subsequent treaties. We can say the same thing of the Spaniards. For the past hundred years they have not made a treaty with the French in which all the advantages have not been on their side. This would take a long time to demonstrate in detail, but I can take an example in the treaty of Cambrécis made in the year 1559. It could not be denied that the strength of the king of France was very great and sufficient to set him above his enemies. Nevertheless the Spaniards gained more in this treaty, without striking a blow, than they had for the past ninety years, for they had never hoped, as they afterwards confessed, to snatch Savoy and Piedmont from the hands of the French. ...

Those who live at the extremities near the poles are phlegmatic and those in the extreme south, melancholic. Those who live thirty degrees below the pole are of a more sanguine complexion, and those who are about midway, sanguine or choleric. Further south they become more choleric or melancholic. They are moreover tanned black or yellow, which are the colours of black melancholy and yellow choler. Galen tells us that phlegm makes a man heavy and dull; blood, joyous and robust; choler, ready and active; melancholy, invariable and set in his ways. There are as many varieties of human types as there are possible ways of combining these four humours. ...

The ancients remarked on the barbarity and cruelty of northern races. Thucydides son of Olorus, King of Thrace, even calls the Thracians a cruel nation. Tacitus, speaking of the Germans says that they do not execute criminals according to the forms of justice, but kill them cruelly, as they serve their enemies. I will content myself with contemporary evidence, without going back to ancient times... We know that the torture of the wheel is employed in Germany, and men are impaled alive in Tartary. They are no less cruel in Lithuania where they compel the condemned to hang themselves, or they first scourge and torture them before they are hanged. Such things make one think that the cruelties that have been published about the King of Muscovy are only 
too likely to be true. The less reasonable men are, and the less they use their judgements, the more they share the brutal nature of beasts, for they cannot be guided by reason nor put any restraints on themselves, any more than can beasts.

On the other hand southern peoples are cruel and vindictive in consequence of their melancholy, which engenders extreme violence in the passions and impels men to take vengeance for what they suffer... Their cruelty is all the more noticeable when it is a question of sentences executed in the course of justice. Such should be without passion and the expression of a sane judgement. Yet we find that the penalties inflicted in ancient Persia passed all measure of cruelty. Even today they flay thieves alive, stuff the skin of the victim and mount it on an ass. The people who live in the temperate regions cannot contemplate, or even hear of such cruelties without horror. It was probably for this reason that the Romans let their criminals die by hunger, and the Greeks gave them the gentlest poison that they knew. The cruelty of the north is therefore not the same as that of the south. The one comes from a brutal impetuosity such as one finds in irrational animals. The other resembles more the deliberate cruelty of the fox who savours his revenge. ...

There is another very notable difference between northerners and southerners, in that the former are modest and chaste, and the latter very libidinous as a result of their melancholy temperament. We read that the Kings of Africa and of Persia always kept a harem of wives. This cannot be imputed to depraved morals seeing that in the New World King Alcazares had four hundred wives, and the father of Atabalippa, the last king of Peru, who was done to death by the Pizarro brothers, had two hundred wives and fifty children... Among the barbarians Tacitus says the Germans only allowed one wife. Sometimes they even lived together in perpetual virginity, as did the Emperor Henry II. Casimir I, King of Poland, and Wenceslas, King of Bohemia, never married at all. This was not however so much that they were chaste, as naturally impotent ... People of the middle regions are moderate in these matters. Their laws for the most part allow one legitimate wife ... The Roman Emperors even made a general law, applying to all peoples indifferently, that the stigma of infamy should attach to anyone who took more than one 
wife. Later they made it a matter of capital punishment. But this law, acceptable to the Romans, was never taken much account of by the Africans, since it was ill-suited to their dispositions. This is what happens to the schemes of anyone who tries to apply laws proper to northern races to people of the south, without considering their dispositions... The historians of the ancient world would make the same sort of mistake in praising the goodness and honesty of the Scythians and their neighbours. They deserve no praise for their virtue who lack the spirit to do evil, and do not know how to sin. Machiavelli was also wrong in saying that the Spaniards, the Italians, and the French were the corruptors of the world. He had not read good books, nor had he experience of other races....

If one considers carefully the natures of the peoples of the northern, southern, and temperate zones, one finds that they can be compared to the three ages of man, youth, age, and maturity, and the qualities characteristic of these ages. Moreover in the governing of their commonwealths, they rely on those appeals which carry most weight in each case. Northerners rely on force, those in the middle regions on justice, and southerners on religion. The magistrate in Germany, says Tacitus, can command nothing except he does it sword in hand. Caesar says in his Memoirs that the Germans have no religion, and only respect prowess in war and the chase. The Scythians, says Solinus, set a sword in the earth and worship that, founding all their actions, laws, religion, and judgements on force and the sword. We find that judicial combats are characteristic of northern races, and are freely enjoined in the laws of the Salians, the Franconians, the Angles, the Ripuarians, and other such peoples. Fronton[8], King of Denmark, enacted that all quarrels were to be settled by combat. No one has ever been able to abrogate these laws, although popes and other princes have tried, regardless of the fact that the nature of northern races is quite different from that of southern. ...

It is equally obvious that laws and the forms of justice originated with the people of the temperate regions such as Asia Minor (where orators and rhetoricians were held in high honour), Greece, Italy, France. It is not just a present day phenomenon that the French are continually employed in litigation. Whatever laws or ordinances are made to diminish 
it, the natural inclination of the people will always reassert itself. In any case it is much better to decide disputes by legal process than by the sword. In short, nearly all the great orators, legislators, jurisconsults, historians, poets, satirists, and all such like who win men's hearts by argument and fair speech, come from the temperate regions. We find in the histories of the Greeks and the Romans that before they embarked on the most insignificant little war, they debated the rights of the case with much discussion, denunciation, and solemn protestation. This is not at all characteristic of northern races, who rush to take up arms at once. They resort to force for all purposes, as do lions; those of the temperate regions to reason and law.

Southern races rely on diplomacy and finesse as do foxes, or they appeal to religion. Rational argument is too mild for the crude northern races, and too prosaic for southerners, who do not want to bother with legal opinion and forensic conjectures, where truth and falsehood are weighed against each other. They wish to be made certain by proofs, or by divine oracles which transcend human reason. Thus we see that southern races, the Egyptians, the Chaldaeans, and the Arabs, have developed the occult, the natural, and the mathematical sciences. These have always fascinated the greatest spirits and constrained them to the pursuit of truth. All great systems of religion have originated in the south and from there have spread throughout the world. Not that God respects either places or peoples, or fails to pour out His divine light over all. But just as the sun is reflected more brilliantly in clear still water than in rough water or a muddy pool, so the divine spirit, so it seems to me, illumines much more clearly pure and untroubled minds than those which are clouded and troubled by earthly affections. If it is true that the soul is purified by divine illumination, and by the force of the contemplation of the most lofty matters, it is understandable that those only arrive at such heights who have wings to raise their souls to heaven. This is the privilege of the melancholy temperament which is composed in spirit, and given to contemplation. This is what the Hebrews and the Platonists call euthanasia because it elevates the soul above its terrestrial body to spiritual realities. It is no wonder then if the people of the south are better ruled by means of religion, than by force or by reason ... Anyone who tried to govern such people by means of the laws and customs observed in Turkey, Greece, Italy, France, and other 
countries of the temperate zone, would soon bring his government to the point of collapse. Similarly anyone who tried to accustom northern people to the legal pleadings of France and Italy would find himself frustrated in the attempt. This was the experience of Matthias, King of Hungary. He sent to Italy for jurists to reform the legal system of Hungary; but in a very short time his subjects found themselves so entangled in legal subtleties that the King was compelled, upon the petition of the Estates, to send the Italians back to their country. ... [9]

One can judge from all these things that the people of the temperate zone are better fitted than the rest for the management of commonwealths, for they have by nature the virtue of prudence, and prudence is the measure of human actions, a touchstone whereby men distinguish good from evil, justice from injury, honest proceedings from dishonest. Prudence is the quality proper to command, just as force which is the characteristic of northern races, is to execution. Southern races, less adapted to political activity, are contented with the contemplation of the natural and divine sciences, and the problem of distinguishing the false from the true. And just as prudence, distinguishing good and evil, is characteristic of people of the temperate zone, and the scientific pursuit of truth to the southern races, so that art which lies in manual dexterity is more marked among northern races than any other.

Spaniards and Italians are filled with admiration at the many and diverse manufactured articles that they import from Germany, England, and Flanders.

There are three principal parts of the soul in a man, that is to say the speculative reason, the practical reason, and the factive imagination. Similarly in the commonwealth priests and philosophers are concerned with the exploration of divine and occult science, magistrates and officers with commanding, judging, and providing for the government of the commonwealth, the ordinary subjects with labour and the mechanical arts. The same characteristics are to be observed in the universal commonwealth of the world. God in His miraculous wisdom has so ordered it that the southern races are ordained to search into the most abstruse 
sciences in order that thereby they might teach the rest. The northern races are ordained to labour and the mechanical arts, and the people of the middle regions to bargain, trade, judge, persuade, command, establish commonwealths, and make laws and ordinances for the other races. The northern peoples from lack of prudence are not apt for this, neither are southern peoples, either because too given up to the contemplation of matters divine and natural, or because they lack that promptness and energy required in human activities, or because they cann ot compromise, nor dissimulate, nor endure the fatigues necessary to a life given to active politics. ...

These are the general characteristics of the different races of men. As for their particular characteristics, there are of course men of all kinds of temperament in all localities and countries, though more or less subject to these general conditions which I have described. Moreover the particular can greatly modify the general character of the country. Though there is no identifiable boundary between east and west, as there is between north and south, all the ancients held that oriental peoples were gentler, more courteous, tractable, and intelligent than western peoples, though less warlike. 'See', said the Emperor Julian, 'how docile and tractable are the Persians and Syrians, the Germans and Celts proud and jealous of their liberty, the Normans both courteous and warlike, the Egyptians intelligent, subtle and generally effeminate.' The Spaniards have observed that the Chinese, the most eastern people we know, are the most intelligent and courteous people in the world, while the Brazilians, the most occidental race, the most barbarous and cruel. In brief, if one reads histories carefully one will find that within the same latitudes the western peoples approximate more to the character of northerners, and orientals to southerners. ...

But the most notable cause of variation is the difference between mountains and plains. Moreover it makes a great difference whether valleys in the same latitude or even on the same parallel are opened to the north or south. This can be seen where a mountain range runs from west to east as do the Apennines dividing Italy into two halves, or the Auvergne mountains in France, the Pyrenees between France and Spain, and the Atlas mountains in Africa, which extend from the Atlantic ocean to the frontiers of Egypt, a distance of six hundred leagues, or the Alps, 
which start in France and stretch as far as Thrace ... In consequence those who live in Tuscany, for instance, are of a very different complexion and much more intelligent than the inhabitants of Lombardy. Again the natives of Aragon, Valencia, and other provinces south of the Pyrenees differ markedly from Gascons and the men of Languedoc, who have many of the characteristics of northern races ... It is no wonder then that the Florentine, whose country lies open on the east and the south and is protected by mountains to the north and west has a much more subtle nature than the Venetian and is more skilled in the management of affairs. All the same, when Florentines attempt collective action they ruin all, whereas Venetians in council manage affairs most capably and have done for the past two hundred years. For men of a less subtle spirit listen to reason, are capable of modifying their opinions, and are guided by the most experienced. But subtle and ambitious spirits hold to their own point of view and abandon their preconceptions with reluctance. As each believes himself capable of commanding the rest they prefer a popular form of government. But they cannot maintain such without incessant disputes and disorders, because of the natural obstinacy characteristic of a southern and melancholic race, or one whose particular situation inclines them to the characteristics of a southern race. ...

But one sees the Swiss Confederates wisely preserve their popular forms of government in a way that the Florentines and inhabitants of Genoa, for all their talents, cannot accomplish. For northern races, or those who live in mountainous regions, are proud and warlike, relying on their physical prowess, and so they prefer popular states, or at any rate elective monarchies, and will not endure to be ruled by pretentious boasters. All their kings are elective, and they expel them the moment they turn tyrant, as was done to the Kings of Sweden, Denmark, Norway, Poland, Bohemia, and Tartary. What I have said about the characteristics of northern countries applies also to mountainous countries, where the climate is often colder than it is in the extreme north ... Their strength and vigour disposes mountaineers to love popular liberty, and to be impatient of dictation. We have pointed this out in the case of the Swiss and the inhabitants of the Grisons. It is also true of the people of Fez, Morocco, and Arabia, who live in complete liberty without anyone lording it over them. This is not a consequence of confidence 
born of the natural impregnability of their country, but comes from their naturally savage nature which cannot be easily tamed. Herein lies the answer to a question raised by Plutarch, as to why the dwellers on the acropolis in Athens demanded a popular form of government, while those of the lower town preferred the government of an aristocratic group. They are much mistaken therefore who wish to convert the popular states of the Swiss, the Grisons and other mountain people into monarchies. For although monarchy is absolutely the best type of government, they are not fit subjects for such a form....

Another factor in the variations of climate is the prevailing wind. Places subject to strong winds induce a different moral type in their inhabitants from other places in the same latitude. Where the air is soft and gentle, men are much more composed and equable than are those who are buffeted by violent tempests. France, especially Languedoc, southern Germany, Hungary, Thrace, Portugal, and Persia are inhabited by men of a much more turbulent and excitable temperament than are the Italians, Anatolians, Assyrians, or Egyptians, where the stillness of the atmosphere makes men much more docile. Marshes also produce a different type of men than do mountains. Even the relative sterility or fertility of the soil modifies the natural effects of climate. Livy remarks that the inhabitants of rich and fertile country are normally mean and cowardly, whereas a barren soil makes men sober of necessity, and in consequence careful, vigilant, and industrious. The Athenians were of this type, and they punished idleness with death. ...

If anyone would understand how nurture, laws, and customs have power to modify the natural disposition of a people, he has only to look at the example of Germany. In Tacitus' day its inhabitants knew neither laws, religion, the sciences, nor any form of commonwealth. Now they are second to none in all these achievements ... On the other hand the Romans have lost the greatness and virtue of their fathers and are nowadays idle, mean, and cowardly ... If the discipline of laws and customs is not maintained, a people will quickly revert to its natural type. If men are transplanted from one country to another, although they do not react as quickly as plants which suck their nourishment from the very soil, nevertheless in time they also will change. The Goths who invaded Spain and southern Languedoc illustrate this point, and so do 
the ancient Gauls who peopled the Black Forest region of Germany. Caesar said that in his time, which was five hundred years after their

migration, they had so changed their nature and their habits as to have become German. ...

We have said in general terms that southern races are by nature contrary to northern races. The latter are tall and robust, the former small and feeble. The one rustic and uncouth, the other courteous and ceremonious. The one extravagant and rapacious, the other tenacious and avaricious. The one warlike, the other philosophical. The one inured to arms and to labour, the other to learning and repose. If the southerner is opinionated, as Plutarch says he is when he is discussing Africans, and sticks to the same ideas throughout his life, the others are obviously unstable and incapable of persisting in anything. But those of the middle region display a mean of virtue, between obstinacy and frivolity. They cannot be dissuaded of their opinions without reason, as can northerners, nor are they so set that they would rather overturn the state than alter their views ... When one considers the inhabitants of the middle region, one must always think of them in relative terms, as having the propensities of the extremities but in a modified form. One must also take into consideration the particular influences of winds, humidity, the soil, the influence of laws and customs, and not merely concern oneself with climate....

So much for the natural inclinations of peoples. As I have said, this compulsion is not of the order of necessity. But it is a very important matter for all those who are concerned with the establishment of the commonwealth, its laws and its customs. They must know when and how to overcome, and when and how to humour these inclinations. Let us now consider means of preventing disorders that arise over the question of property.

How to Prevent those Disorders which spring from Excessive Wealth and Excessive Poverty [CHAPTER II]

THE commonest cause of disorders and revolutions in commonwealths has always been the too great wealth of a handful of citizens, and the too great poverty of the rest. The histories are full of occasions on which 
those who have given all sorts of reasons for their discontents have taken the first opportunity that offered of despoiling the rich of their possessions ... For this reason Plato called riches and poverty the two original plagues of the commonwealth, not only because of the misery that hunger occasions, but the shame, and shame is a very evil and dangerous malady. To remedy this condition of things, it has been suggested that there should be an equality of possessions. This suggestion has been strongly supported, and it has been claimed that it would prove a source of peace and amity among subjects, whereas inequality is the source of enmity, faction, hatred, and prejudice. He who has more than another, and is conscious of being richer in possessions, thinks he should also enjoy a greater measure of honour, luxury, pleasure, have more food and more clothes. He thinks he should be looked up to by the poor whom he despises and treads underfoot. The poor, for their part, suffer acute envy and jealousy in considering themselves just as worthy or even more worthy of riches, yet oppressed by hunger, poverty, misery, and contempt. Therefore many architects of republics in the ancient world advocated an equal division of property among all subjects. Even within living memory Thomas More, the Chancellor of England, in his Republic laid down that a necessary condition of general well-being was that men should enjoy a community of goods, which is not possible where there are private property rights ... Lycurgus accomplished this at the risk of his life, for after having prohibited the circulation of gold and silver, he made an equal division of all lands... The Romans as a people were more equitable and had more understanding of the principles of justice than any other. They often decreed a general remission of debts, sometimes to the amount of one quarter, or one third, sometimes even the whole amount. This was the best and quickest way they found of composing disorders and discontents.

On the other side it can be argued that equality of possessions is subversive of the commonwealth. The surest foundation of a commonwealth is public confidence, for without it neither justice, nor any sort of lasting association is possible. Confidence only arises where promises and legal obligations are honoured. If these obligations are cancelled, contracts annulled, debts abolished, what else can one expect but the total subversion of the state, for none would any longer have any 
confidence in his fellows ... But if the inconveniences of such abolitions are obvious, still more unfortunate is the equal division of lands and possessions which are cither rightful inheritances, or justly acquired. In the case of debts, one can make the excuse of usury. But this cannot be alleged against lands legitimately inherited. Such partitions of the goods of another is robbery in the name of equality. Moreover to say that equality is the mother of amity is to abuse the ignorant, for there is no hatred so bitter, or enmity so deadly as that between equals. Jealousy of equals one of another is the source of unrest, disorder, and civil war. On the other hand the poor, the weak, and the unprotected defer to and obey their betters, the rich and the powerful, most willingly, with a view to their assistance, and the advantages they hope will accrue....

Besides, what Lycurgus intended in dividing up property among individuals to preserve equality of heritages in perpetuity was a thing impossible of achievement. He could see for himself that the original equality between individuals was almost immediately upset by the fact that some parents had twelve or fifteen children, and others one or two, or even none at all... Some, like Hippodamus the Milesian lawgiver, have tried to solve this difficulty by limiting the citizen body to ten thousand ... Sir Thomas More, the English Chancellor, thought that no family should consist of less than ten or more than sixteen children, as if he could command nature ... But one should never be afraid of having too many subjects or too many citizens, for the strength of the commonwealth consists in men. Moreover the greater the multitude of citizens, the greater check there is on factious seditions. For there will be many in an intermediate position between the rich and the poor, the good and the bad, the wise and the foolish. There is nothing more dangerous to the commonwealth than that its subjects should be divided into two factions, with none to mediate between them. This is the normal situation in a small commonwealth of few citizens. Let us therefore reject the schemes of those who wish to introduce equality of property in commonwealths already founded, by taking a man's property from him, instead of securing to each that which belongs to him, for this is the only way of establishing natural justice. Let us also reject the idea of limiting the number of citizens, and conclude that there should be no partition of inheritances except on the foundation of a new commonwealth 
in a conquered country. In such case the division should be by families and not by individuals, and a certain pre-eminence should be accorded to one particular family, and an order of priority established within each family. ...

The law of God shows us plainly how matters should be arranged ... By that law the principle of an exact equality is not sustained, for some are assigned more, some less than others. The tribe of Levi apart, there was an even distribution of lands among the twelve tribes. In the family there was an equal division of property among the younger sons, saving the right of the first-born (to a double portion). He was not allowed even four-fifths or two-thirds, much less the whole of the inheritance. This was for fear that so great a degree of inequality might occasion fratricides, quarrels between the tribes, or conflicts and civil wars between subjects. But in order to maintain this balance between too much or too little, alienation either to living persons, or by will, must not be prohibited, as it is in some places, provided that the provisions of the law of God are observed. That is to say all alienated inheritances revert to the house or family from which they have been withdrawn after fifty years. In this way those who get into difficulties, and have to sell their heritages in order to provide for the necessities of life, can redeem them any time within fifty years, at which term they will return to them or their heirs. In this way bad managers are not able to dissipate their estates permanently, and the avarice of successful managers is kept in check.

As to the abolition of debts, such a proceeding sets a very bad example, as already said. This is not so much because of the loss to creditors, for this is a matter of little moment by comparison with the public interest. What is more serious is the excuse it affords of violating legitimate agreements, and the encouragement it gives to dissatisfied persons to make trouble, in the hope of promoting a remission of debts. $\cdots$

What is most to be feared is that one of the estates of the commonwealth, and that the weakest and least numerous, should become as rich as all the rest put together. This was once the position of the estate of the clergy. An estate of the commonwealth which numbered only 
one hundredth part of the subjects, collected tithes of all sorts, and, in defiance of the decrees of the primitive Church, as the popes themselves confessed, secured testamentary bequests of both movables and real estate, duchies, counties, baronies, fiefs, castles, houses in town and country, rents all over the place, and sold or exchanged them, and acquired and pledged the revenues of benefices to use the money for further acquisitions. Moreover all this property was exempt from taxes, imposts, and charges of all sorts. It was in the end found necessary to issue an injunction requiring ecclesiastics to surrender inheritances and real estate left to the Church, within a certain time on pain of confiscation, as was done in England by a statute of King Edward I ... I am not concerned as to whether this property was employed as it ought to have been. What I do say is that so unequal a distribution was perhaps the cause of the disorders and revolts against the estate of the clergy which broke out over practically all Europe, though all was done under the pretext of religion. But if that pretext had not been to hand, another would have been found, as was the case earlier when attacks were made on the Order of the Temple, and on the Jews....

It would seem however that where the eldest son succeeds of right to the whole estate, as was the rule with the seven thousand Spartan citizens, the splendour and dignity of ancient families is much better preserved and their decline prevented. This, it is argued, benefits the whole estate of the realm, for it is the more firmly established and more stable for being founded on old-established families as upon great and immovable pillars. The weight of a great building cannot be borne by slender columns, even if they are numerous. In fact it appears that the greatness of the kingdoms of France and Spain is largely due to their noble and illustrious houses, and on their ancient guilds and corporations, which once dismembered would lose their value.

But this argument appears more convincing than it is, except where the state is an aristocracy. What the monarch, especially the despotic or tyrannical monarch, has most to fear, are the noble houses and powerful guilds and corporations. As for the popular state, based as it is upon the principle of equality in all things, how can it allow so great an inequality within families that one inherits all and the rest starve? All the rebellions that vexed Greece and Rome arose out of this 
circumstance. But in the aristocratic state, where the rulers are in principle not the equals of ordinary folk, the custom of primogeniture is preservative, as it was in the aristocratic state of Sparta. ...

Concerning Rewards and Punishments [CHAPTER IV][10]

THE subject of rewards and punishments must be treated very briefly. To do so exhaustively would require a major work, for these two things affect every aspect of the life of all commonwealths. If punishments and rewards are well and wisely distributed, the commonwealth will continue happy and flourishing. But if able and upright citizens do not receive the reward of their merits, or wicked ones the punishments which they deserve, there is no hope that the commonwealth can long endure. There is probably no more frequent occasion, or more immediate cause of troubles, disorders, and civil wars, leading to the downfall of commonwealths than the neglect of men of ability, and the favour that it shows to the unworthy. It is not however so necessary to discuss punishment as to discuss rewards, since all laws and customs deal extensively with them, for vice is commoner than virtue, and there are more wicked men than virtuous. But since punishments are in themselves hateful, and rewards acceptable, wise princes have always been accustomed to hand over the infliction of penalties to magistrates, but to reserve the bestowing of favours to themselves. They thus win the love of their subjects and avoid all ill will. For this reason jurists and magistrates have treated the theme of punishment very fully but hardly touched on rewards. ...

All rewards are either honourable or profitable ... When we speak of rewards we mean triumphs, statues, honourable charges, estates, offices, benefices, gifts; or immunities from all or some particular burdens such as tallages, imposts, wardship, military service, and exemptions from the jurisdiction of the ordinary courts; or letters patent of citizenship, of legitimization, of nobility, knighthood, and such like honours. If however the office is an obligation without honour, then it is not a reward, but on the contrary a charge or burden.

Honours must not be confused with favours, for honours are the reward of merit, but favours are acts of grace. The diversity of character in 
commonwealths diversifies the principles on which honours and favours are distributed. There is a great difference between monarchies and popular and aristocratic states. In popular states rewards are more honourable than profitable, for humble folks are only concerned with profit, and care little about honours. They therefore bestow them easily and willingly on those who want them. The contrary is the case in a monarchy, for the prince, who distributes all awards, is more jealous of bestowing honour than profit. In a tyranny especially, there is nothing that a prince more dislikes than to see a subject honoured and respected, for he fears that a taste for honours will incite the subject to aspire higher, and aim at the state itself. Sometimes the nature of the tyrant is such that he cannot endure the light of virtue. We read of the Emperor Caligula, that he was jealous and envious of the honour paid to God Himself, of the Emperor Domitian, the meanest and most cowardly tyrant that ever was, that he was so unable to endure that honour should be paid to those who had most merited it, that he caused them to be put to death. Instead of rewarding illustrious citizens, princes do sometimes cause them to be killed, or banished, or condemned to perpetual imprisonment in order to safeguard their own position. Alexander the Great did this to his Constable Parmenion, Justinian to Belisarius, Edward IV to the Earl of Warwick. Many others have been killed, poisoned, or maltreated as a reward for their prowess....

One never finds monarchs therefore and still less tyrants, who are willing to grant triumphs or state entries to their subjects, however overwhelming the victory they may have won over the enemy. On the contrary, the wise captain, in place of a triumph on his return from the wars bares his head before his sovereign with the words, 'yours, Sire, is the glory', even though the prince was nowhere near the field of battle ... One could of course say of popular states as well that the victory of its captains is ascribed to the people under whose banner they fought. Nevertheless the honour of a triumph is accorded the captain, a thing which never happens in a monarchy. This is the principal, and perhaps the sole reason, why there is always a greater number of illustrious citizens to be found in well-ordered popular states than in a monarchy. Honour, which is the sole reward of virtue, is denied or severely restricted in the case of those who have merited it in a monarchy, but freely granted in a well-ordered popular state, especially for prowess in war. A high and generous spirit covets honour more than all the riches in the world, and will not hesitate to 
sacrifice life and possessions for the sake of the glory it aspires to. The greater the honours awarded, the more men will be forthcoming who merit them. It was for this reason that the Roman Republic produced more great captains, wise senators, eloquent orators, and learned judges than any other republic, barbarian, Greek, or Latin. Anyone who had put to flight a legion of the enemy could demand a triumph, or at least some honourable distinction, and he could hardly fail to achieve one or the other ... The wisdom of the ancient Romans is to be much admired in this respect. By the same expedient they avoided both a money recompense and the appeal to avarice, and engraved the love of virtue on the hearts of their subjects with the graving-tool of honour. Other princes found enough money for material rewards with the greatest difficulty, exhausting their revenues, selling domain, oppressing their subjects by confiscating the property of some and despoiling others to recompense their creatures (though indeed virtue cannot be calculated in terms of money). The Romans only gave honours. ...

It is however impossible ever to control the distribution of honours and punishments once the prince has offered offices and benefices for sale. This is the most dangerous and pernicious evil that can befall the commonwealth. All nations have provided against it by good laws. In this kingdom the ordinances of St. Louis brand with infamy those who have used influence to get offices of justice. This rule was well kept till the time of Francis I, and is most strictly observed in England, as I have learned from the English ambassador Randon[11] ... There is no need to enumerate the disadvantages and miseries that befall the Republic where office is sold; it would be a long recital, and only too familiar to everyone. It is more difficult to persuade a popular state that such traffic is desirable than an aristocracy. It is a means of excluding the lower classes from positions of importance, for in popular states the poor expect to enjoy office without paying for it. All the same, it is not easy even there to enforce the prohibition when the poor see a chance of profit in electing ambitious men.

In the case of a monarchy, financial pressure sometimes forces the monarch to set aside good laws to relieve his necessity. But once one has opened the door to such a practice, it is almost impossible to halt the decline ... For it is unquestionable that those who put honours, 
offices, and benefices up for sale, thereby sell the most precious thing in this world, and that is justice. They sell the commonwealth, they sell the blood of its subjects, they sell the laws. In taking away the rewards of honour, virtue, learning, piety, and religion, they open the door to robbery, extortion, avarice, injustice, ignorance, impiety, in short, every sort of vice and corruption. The prince cannot excuse himself on grounds of poverty. There is no real or even likely excuse for compassing the ruin of the commonwealth under cover of poverty. It is in any case ridiculous for a prince to plead poverty when there are so many other ways of relieving it, if he will give his mind to the matter....

Let then the prince leave the infliction of punishments to his magistrates and officers, as we have said is expedient, and himself distribute honours to whom they pertain, giving favours little by little, in order that the grace may be more lasting, and punishments immediately, in order that the pain may be less grievous to him who suffers it, and fear the better impressed on the hearts of the rest. In so doing, he will not only fill the commonwealth with virtuous men and drive out the wicked, which is the sum of the felicity of the commonwealth, but he will acquit himself of his debts, if he is indebted, and if be is quit already, he will preserve the funds in his treasury. ...

Therefore if on enquiry into the career and character of all who aspire to honours, offices, benefices, knighthoods, exemptions, immunities, gifts, and honours of all sorts, their lives are found to be evil and depraved, not only ought they to be refused, but punished. But honours should be given to worthy men, according to the deserts of each on the principle of harmonic justice. That is to say that finance should go to the most honest, arms to the bravest, justice to the most upright, moral discipline to those of greatest integrity, work to the strongest, government to the wisest, priesthood to the most devout. At the same time due regard must be paid to the birth, riches, age, and capacity of each, and the requirements of the various charges and offices. For it is ridiculous to seek to appoint a warlike judge, a courageous prelate, a conscientious soldier....[12] 
Whether it is expedient to Arm Subjects, Fortify, and organize for War [CHAPTER V]

THIS is one of the most important problems of policy, and one of the most difficult to solve, because of the disadvantages of either course of action. I will summarize them as well as I can, and indicate what I think the best course, but the practical solution must be left to the skill of statesmen. Simply to follow Aristotle and say that the city should be well fortified, and so placed as to be a good base for aggressive operations, but difficult of access to the enemy, does not take into account the real difficulties. One must consider whether the same policy is as suitable in a monarchy as in a popular state, and in a tyranny as in a kingdom, seeing that, as we have already shown, commonwealths of contrary tendencies need regulating by contrary institutions.

It is said, for instance, that nothing is more destructive of a warlike spirit in the subject than fortifications, since they turn the inhabitants into cowards ... Again, citadels and defence works encourage bad rulers to oppress their subjects. Strong walls also enable subjects to rebel against their sovereign lords and rulers. For this reason the Kings of England do not allow any of their subjects to fortify their houses, even with a moat ... But all fortified cities, which cannot hope to sustain a long siege, generally treat and secure the withdrawal of the enemy by an indemnity, and they can do this without any shame or reproach ... This could not be done if the city were well fortified, because of the dishonour attached to those who make composition with an enemy they could have resisted ... If then it is true that fortresses offer opportunities to evil princes to tyrannize over their subjects, to enemies to occupy the country, to subjects to show themselves cowards in the face of the enemy, rebel against their prince, and scheme against one another, it cannot be argued that they are either useful or necessary, but on the contrary, they are harmful and destructive of the commonwealth.

But on the general question of whether one should train citizens to arms, and seek war rather than peace, there appears to be no doubt as to the answer. A commonwealth is to be esteemed happy where the king is 
obedient to divine and natural law, the magistrate to the king, subjects to the magistrate, children to parents, servants to masters, and where subjects are bound to each other and to their prince by ties of affection, for the enjoyment of the blessings of peace and true tranquillity of spirit. War is a condition quite contrary to this, and warriors are sworn enemies to such a way of life. It is not possible for religion, justice, charity, security of life, in short, all the liberal sciences and mechanical arts to nourish in any commonwealth which does not enjoy a profound and lasting peace. But such a state of affairs is ruination to professional soldiers, for times of piping peace render their calling useless. No one is a greater enemy to a man of peace than a rough soldier, to the good peasant than brutal mercenary, to the philosopher than the captain, to the wise than fools. What the fighting man most enjoys is to devastate the countryside, rob peasants, bum villages, besiege, storm and sack towns, slaughter good and evil alike, young and old of whatever age or sex, ravish women, drench themselves in blood, defile sacred things, raze churches, blaspheme the holy name, and tread underfoot all rights, human and divine. Such are the fruits of war, pleasing and agreeable to men of war, but abominable to men of good will, and detestable in the sight of God. There is no need to enlarge upon what has been practised in so many places, when the very memory is sufficient to make the hair of the boldest stand on end. If this be so then one should on no account train subjects in arms and start them on the road to so execrable a way of life, nor indeed make war at all, except as a measure of defence in cases of extreme necessity. ...

Such are the arguments on one side. But one can argue on the other side that unfortified towns are exposed to spoliation by the first comer, and the lives of their inhabitants are at the mercy of all. Moreover it would appear that open towns are a temptation to all those who contemplate aggression, whereas walls deprive the enemy of both the will and the power to attack. In like case those who travel unarmed invite thieves and robbers to kill them for what they carry on them. One knows very well that the loot of captured towns is held out as a reward to troops. They are the natural enemies of the weak, but dare attempt little against the well-armed. It must also be remembered that the first and only occasion of men gathering together into societies and communities was for the safety and defence of each in particular and all 
in general whether women and children, or goods and chattels. This could not be secured unless towns were fortified. For to say that men are the best defence against the enemy is only applicable on the actual field of battle. In any case those who can thus defend themselves are never more than a fourth part of the inhabitants, for there are always more women than men in any community, and there are besides children and old people, the sick and the helpless, and their protection must he in strong walls. It is moreover ridiculous to say that men are more valiant if they have no fortifications to rely on. If this is so, one should not permit the use of a shield or defensive armour in face of the enemy. Logically we should then prohibit men from fighting otherwise than quite naked ... Besides, the experience of many centuries has shown that we must do as the Persians, the Egyptians, the Greeks, the Romans, and the Gauls did of old, and fortify, equip with arms, and provision towns, ports and fortifiable sites, for the defence and security of friends, and resistance against the enemy.

Such are the arguments in support of the view that towns should be fortified. For the same reasons we hold that the subject should be trained to arms. For since the right to preserve life and punish thieves is recognized by divine, natural, and positive law, it must be presumed that subjects ought to be practised in arms, not only for defensive, but also for offensive purposes, in order to shield the innocent and repulse the wicked. I call all those who bring unjust war, and lay hands upon the possessions of others, thieves and villains. If one must take vengeance on thievish and predatory subjects, it follows that one must also do so on foreigners who behave as such, whatever title of kingship they bear. This obligation is founded on divine and natural law.

There are other and more particular considerations. In the first place, the best way of preserving a state, and guaranteeing it against sedition, rebellion, and civil war is to keep the subjects in amity one with another, and to this end, to find an enemy against whom they can make common cause. Examples of this can be found in all commonwealths. The Romans are a specially good illustration. They could find no better antidote to civil war, nor one more certain in its effects, than to oppose an enemy to the citizens. On one occasion, when they were engaged in bitter mutual strife, the enemy found his way into the city and 
seized the Capitol. The citizens instantly composed their differences, and united to expel the enemy... Without looking further afield, we have an example in this kingdom when it was in grave peril in 1562. The English set foot in France and seized Havre de Grace, whereupon the civil war was abandoned, and the subjects united to make common cause against the enemy. Perceiving which, the English resolved to leave the French to fight one another, and wait till they were thereby altogether ruined, when they might invade the kingdom without difficulty, or the danger of encountering resistance. ...

Unrestrained freedom inflates men and encourages them to abandon themselves to every sort of vice. Fear however keeps them mindful of their duty. One can have no doubt that the great Ruler and Governor of the whole world, in creating things so that each is balanced by its contrary, permits wars and enmities between men to punish them the one by the other, and keep all in fear, for fear is the sole inducement to virtue. When Samuel addressed the people, he told them plainly that God had raised up enemies against them to keep them humble, and to try, prove, and punish them. These considerations serve to show how wrong are those who say that the sole end of war is peace. ...

These arguments have a measure of truth, and are in part valid, and can on the one side or the other blind the eyes of the most clear-sighted, if one does not look too carefully into them. To resolve the problem satisfactorily one must distinguish between the different kinds of commonwealth. I hold that in a popular state it is expedient to train the subjects to arms because of the weaknesses to which I infer popular states are prone by their very nature. If the subjects are naturally warlike and intractable, as are northern peoples, once they are trained in the art of war and in military discipline, it is expedient to keep them frequently engaged against an enemy, and only make peace, a condition not adapted to a warlike people, on very advantageous terms. Even when peace is concluded, an army must be maintained and kept on the frontiers. This was Augustus' policy after he had converted a popular state into a monarchy. The alternative is to hire them out to allied princes, as the governments of the Confederates very wisely do, to keep them practised in the military art. They have to deal with a mountain population, apt for war and difficult to keep at peace, and used to the 
enjoyment of popular liberty. By this policy they are always provided with experienced soldiers, maintained at the expense of others, who at the same time earn considerable subsidies for the state, and pensions for individuals. Added to which their safety is assured by the alliances thus formed with some puissant king.

As to fortifications, there is no need for the towns to be very heavily fortified except the capital city, which is the seat of government in a popular state. Even less is there any need of a multiplication of castles and citadels. For one may be sure that ambition will move someone or other to seize a fortified place, and then convert the popular state into a monarchy, as did Dionysius the tyrant, after taking Acradine in Syracuse ... In our own day Cosimo de' Medici, Duke of Florence, constructed two citadels in Florence and garrisoned them with foreigners, having found out that it was impossible to live secure in the midst of his subjects once he had converted the popular state into a monarchy. Such considerations explain why the Cantons of Uri, Interwalden, Glarus, and Appenzel, which are extreme democracies, have no fortified towns as have the others whose government is aristocratic.

The same considerations regarding fortresses hold good in aristocracies as in popular states, for there is no less danger that one of the seigneurs will make himself master of his colleagues. Indeed it is even more to be feared in that it is easier for one of the seigneurs to secure a following among the simple citizens and so make head against the more powerful. Above all, in kingdoms which are long-established and extensive, it is never expedient for the prince to erect citadels and strongholds except on the frontiers, least his subjects suspect that he intends to become their tyrant. But if he encircles his kingdom with strong frontier posts, his subjects will believe that they are directed against the enemy, and the prince, at need, can use them either to repel the enemy, or master his subjects should they rebel. ...

So much for fortifications. It is much more difficult to determine, in an aristocracy, whether it is better to arm only the governing class, or the ordinary citizen as well, or to keep all indifferently unarmed. If the lower classes are once armed, and not then constantly employed against the enemy, there is no doubt that sooner or later they will try 
to, and succeed in, changing the form of the government in order to have a share themselves, as I have already shown. If only the ruling class is armed, one day they will be defeated in the field, and again, this will of necessity entail a change of government. If on the other hand they prohibit the practice of military art altogether in the commonwealth, they will by and by fall a prey to their neighbours, unless protected by a close alliance with powerful friends, or unless their cities are inaccessible and their fortifications impregnable. There is the example of the Venetians. Fearful of the dangers I have described, they prohibited the practice of arms altogether, as the Cardinal Contarini has shown, though they achieved this only gradually over a period of about two hundred years. They were once a belligerent people, and sustained long wars, and beat the Genoese in set battles by sea and by land. But since then they have enjoyed a long period of secure peace, and have gradually abandoned the military arts, relying for their assistance on foreigners... And if, as many think, one should only make war to secure peace, and all that is required for the welfare of the commonwealth is that by being well armed and fortified it can defend its own against an enemy and enjoy the blessings of peace, the Republic of Venice may be called happy. It is situated in an impregnable position, and cares little for conquest, or the expansion of its territories. We find that the Venetians have always avoided war like the plague, and never wage it save in cases of extreme necessity, but seek peace at any price, even at the cost of the loss and diminution of their domains ... But such a policy seems contemptible to a warlike people, or an ambitious prince, who cannot sue for peace at the hands of the enemy without shame....

A wise prince should never permit the enemy to invade his kingdom if he can by any means scatter their forces or check their advance before they can cross the frontier, or at any rate unless he has a second army, and some impregnable base to which he can retreat. Otherwise he risks all on a single battle. This was the error of Antiochus, Perseus, and Ptolemy, the last King of Egypt, in the war with the Romans; of Darius in the war with Alexander, and the French time and time again in the wars with England ... But Francis I took his army across the Alps in order to keep his country free from war, and attacked the enemy in laying siege to Pavia. Apart from the devastation which two powerful armies would have 
caused in France, the capture of the King would have exposed the kingdom to great danger. But happening, as it did, in Italy, and the victors being at first content with their success, time was given to the King's subjects to rally their forces and secure the frontiers ... I do not wish to enter into any discussion of the art of war, for others have treated of this subject.[13] I am only concerned with what touches the state. I hold that the prince should provide for the thorough fortification of his frontiers, and if he suspects that any enemy contemplates invading his territory, he ought to anticipate him and wage war as far from his own frontiers as possible....

Experienced statesmen separate the profession of arms from other employments. In the Republic of Crete only certain persons were permitted to bear arms, just as in France in ancient times only men provided with a horse had such a duty, and the druids were exempt... For this reason Plato divided the people into three classes of guardians, warriors, and producers, following in this the example of the Egyptians who distinguished three estates, according to employment. Gradually the Athenians too separated the profession of arms from that of justice and administration. The Romans did the same in the time of the Emperor Augustus. He forbad to senators, proconsuls, and governors of provinces the carrying of arms, so much so that in course of time non-military offices came to be known as honours, as we may read in Cassiodorus' letters, concerning the state of a provincial governor. In consequence all nations in their turn separated the callings of arms, and of justice and civil administration. For it is very difficult to excel in one profession, and quite impossible in many. One cannot worthily fill many offices. Furthermore it is almost impossible to train all the subjects of a commonwealth in the use of arms, and at the same time keep them obedient to the laws and to the magistrates. ...

This was the reason why Francis I disbanded the seven regiments each of six thousand foot in 1534. Although his successor raised them again eighteen years later, they had to be again disbanded because of the disorders and riots they occasioned in various places. All the same, in the opinion of foreign experts who had examined the ordinances establishing these regiments, no better scheme could have been devised for fostering the profession of arms. It is a policy more necessary to 
this country than any other in the world, seeing that it is surrounded by powerful neighbours who have the habit of raiding it as if it were conquered territory. ...

In conclusion it seems to me that the well-ordered commonwealth of any type whatsoever should keep its approaches and frontiers well fortified, and should provide itself with an adequate force of trained fighting men. These should be maintained by grants of land reserved for combatants, but granted for life only, as was originally the practice with fiefs and feudal lands, and as is still the practice with the timars and timariots of Turkey, on condition that they serve four or at the least three months of the year without pay, following ancient custom. Moreover it must be emphasized that these holdings can no more be made heritable, pledged, or alienated than can benefices.

Until the time that one can restore the original character of fiefs, a certain number of regiments of foot soldiers and mounted men should be raised, according to the importance, extent, and greatness of the commonwealth. In time of peace these men should be trained in military discipline from their youth up, in garrison duty on the frontiers, after the example of the ancient Romans. The Romans did not even expect free maintenance for their pains, much less the right to loot, rob, beat up, and murder civilians as troops now do. A camp with them was a school of honour, of sobriety, chastity, justice, and virtue, and no one was allowed to avenge his own injuries or take the law into his own hands.

In order to maintain this discipline, one should follow the Turkish practice and reward good officers and men, especially when they grow old, with certain exemptions, privileges, immunities, and benefits. It is not excessive if a third part of the revenues are assigned to the payment of the army, in order to secure that there are men ready for the defence of the state when need arises, especially if the commonwealth is an object of envy, and surrounded by warlike neighbours, as are the people inhabiting the temperate and fertile regions of France, Italy, Hungary, Greece, Asia Minor, Syria, Egypt, Persia, and the islands of the Mediterranean. The people situated at the extremes of north and south, such as the Ethiopians, Numidians, Negroes, Tartars, Goths, Russians, Scots, and Swedes have no need of strong fortifications or 
standing armies in times of peace, having no enemies other than themselves. In any case the people of the extreme north are naturally only too warlike. Most or all of them are horsemen and skilled in arms, and need no special training for such pursuits, or to be set to fight, unless it be to rid the country of those that cannot be induced to live peaceably....

For the rest, the carrying of arms should be forbidden to all other subjects in order that labourers and craftsmen should not be tempted to desert the plough and the workshop and take to robbery. Not having any experience of the proper use of weapons, when it is a question of marching against the enemy, they either desert, or panic at the first onset and throw the whole army into confusion. As Thomas More says in his Republic, all the ancients and all wise captains agree that craftsmen and men of sedentary occupations, used to security, are totally unfitted for the business of war.

The keeping of Treaties and Alliances between Princes [CHAPTER VI]

THIS discussion arises out of the foregoing, and must on no account be omitted, seeing that writers on law and politics have never treated of it, though there is no matter of state that more exercises the minds of princes and rulers than the securing of treaties, whether with friends, enemies, neutrals, or their own subjects. Some rely on mutual good faith simply. Others demand hostages. Many add the surrender of fortified places. Others cannot feel safe unless they totally disarm the conquered. It it has always been considered that the best guarantee of a treaty is ratification by a marriage alliance. But just as there is a difference between friends and enemies, victors and vanquished, equals in power and the weak, princes and subjects, so also must the forms of treaties and their appropriate guarantees be diversified. But there is one general and indisputable principle to be observed, and that is that in all treaties there is no better guarantee of its observation than that the clauses and conditions included in it should be suitable to the parties concerned, and conformable to the matters in dispute....

As we have shown, true protection is given where a prince freely undertakes to defend another without recompense of any kind. 
Nevertheless for the better securing of these treaties of protection or commendation, it is customary to offer a pension to the protector or advocate, in the hope that the protector, being bound not only by his oath, but by the payments received, will be more ready to succour his adherent when need arises. It is true that the ancients never followed such a proceeding. But now that honour is weighed against profit, protection is sold for money. This is why a Salvian of Marseilles[14] complains that when the weak seek the protection of the strong, they have to part with all they have to secure it. One knows what enormous sums the people of Lucca, Parma, and Siena, and many other towns, disbursed for their protection.[15] Often enough the pension is paid not so much to secure oneself against one's enemies, as against the protector himself. This happened after the battle of Pavia. All the rulers of Italy turned their attention to the Spaniards, and in order to buy themselves off from the threat of invasion, put themselves under their protection. ...

Treaties of protection expose the protected party to much greater risks than any other kind of alliance, and therefore it is important that the guarantees should be most carefully considered. For lack of such, how often has one not seen an obligation to protect trans formed into sovereign rights. He feels safe indeed who commits the sheep to the care of the wolf. It is therefore in the first instance important that treaties of protection should be limited in time, even in the case of aristocracies and popular states where the ruler never dies. For this reason when Geneva put itself under the protection of Berne, the citizens did not wish to bind themselves for more than thirty years. The treaty expired in 1558, when Geneva proposed an alliance with Berne on equal terms. This was only concluded with great difficulty, and only after a crisis in which the city was nearly brought into subjection through the machinations of certain citizens who paid the penalty with their lives ... But the best guarantee for the protected party is to prevent, if possible, the seizure of the fortresses of their towns by the troops of the protector and the introduction of his garrisons into them. The words of the Tribune Brutus to the nobles and people of Rome should never be forgotten, that the only protection that the weak have against the strong whom they fear, is that the latter should not be able to harm them even if they wish to, for the desire to do harm is never 
lacking in ambitious men who have power to inflict it. On these grounds the Scots were wise when in the treaty which they made in 1559 with the Queen of England, to secure her protection, they stipulated that the hostages surrendered should be changed every six months, and that no fortress should be constructed in Scotland without the consent of the Scots themselves. ...[16]

Many think that it is safest for a prince to adopt a policy of neutrality, and so keep out of other people's wars. The principal argument in support of this view is that whereas loss and expense is shared in common, the fruits of victory all accrue to the ruler on whose behalf the quarrel is sustained, added to which one must declare oneself the enemy of princes who have in no way offended one's interests. But he who remains neutral often finds means to reconcile enemies, and so remains himself everyone's friend, and receives honours and rewards at the hands of both parties. If all princes were aligned against one another in hostile camps, who could compose their differences' And again, what better way is there of maintaining one's state in all its strength than to stand aside while one's neighbours ruin one another? In truth, the greatness of a prince largely depends on the decline and fall of his neighbours, and his strength is measured by other people's weakness. ...

But the arguments on the other side appear stronger. First of all, in matters of state one ought always to be either the stronger, or of the stronger party. There are few exceptions to this rule, whether one is considering a single commonwealth, or a number of princes. Otherwise one falls a prey to the whim of the victor ... Without looking further afield, we have the example of the Florentines. Having abandoned their alliance with the French royal house, but at the same time refusing to join the league of the Pope, the Emperor, the Kings of England and of Spain, they almost immediately felt the evil effects of their neutrality. Someone may object that it was not open to them to join the League. That is true. But it was not open to them either to abandon their obligations to an ally at will, as they $\operatorname{did}[17]$... One cannot take up a neutral position if one owes assistance to one of the parties under some treaty. The only way of remaining neutral without going in fear of the victor is to secure the consent of the other parties to such 
a course of action. In fact the duchies of Lorraine, Burgundy, and Savoy maintained their independence so long as they followed a policy of neutrality. But as soon as the Duke of Savoy took sides with the Spaniards, the French drove him from his principality.[18] But there is a great difference in being neutral because the friend of neither party, and neutral because the ally of both. The latter situation is much the safer, since one is secure from attack by the victors, and if any treaties are agreed upon by the contending parties, one is included by both sides.

If neutrality is to be commended in such a case, it is even more laudable in a great prince who surpasses all others in power and dignity. To him falls the honour of being judge and arbiter, for it always happens that the quarrels between princes are composed by some common friend, especially by those who stand above all the others in greatness. In former times many popes, who rightly understood their office, made it their business to reconcile Christian princes and thereby win honour and respect, and favours and protection for their own person and for their office. But those who took sides with one or other party brought ruin on others. The Spaniards thought it very unfitting that Alexander VI, himself a Spaniard by birth, should ally with Louis XII against them. But when the Spaniards themselves had the mastery, he said to the French ambassador that he considered it his role to remain neutral. But it was a little late to try and extinguish the fire he had kindled by putting on a show of piety. ...[19]

Good faith is little regarded by many princes in the alliances which they make with one another. What is more, there are those so perfidious that they only enter into solemn engagements with the intention of deceiving, in this emulating the captain Lysander, who boasted that he cheated adults by his sworn assurances, and children by his conjuring. But God punished his perfidy according to his merits. Perjury is more to be detested than atheism. Since the atheist does not believe in God, he cannot sin so gravely against one in whose existence he does not believe, as the man who does believe, and mocks God in perjuring himself. Perjury therefore always implies impiety and a wicked heart, for he who swears in order to deceive evidently mocks God, fearing only his enemy. It would be better never to call God to witness, or that 
power one believes to be God, only to mock Him, but only call oneself to witness. That is what Richard, Count of Poitiers, son of the King of England did when he confirmed the privileges of La Rochelle, he simply added the words teste meipso.

Since faith is the sole foundation and prop of that justice on which all commonwealths, alliances, and associations of men whatsoever, is founded, it should be preserved sacred and inviolable in all cases where no injustice is contemplated. This applies most particularly to the relations between princes, for seeing that they are the guarantors of good faith and sworn engagements, what assurance will those subject to them have of their own mutual undertakings if the rulers themselves are the principal breakers and violators of good faith? I have added, 'in all cases where no injustice is contemplated', for it is a double sin to engage one's faith to do an evil act. In such a case he who fails of his promise, so far from being perfidious, is to be commended. In like case, if the prince promises not to do something permitted by natural law, he is not perjured if he breaks his oath. Even the subject is not foresworn who breaks his oath regarding any action permitted by the law. But wise princes should never bind themselves by oath to other princes to do anything forbidden by natural law, or the law of nations, nor should they ever compel princes weaker than themselves to swear to an agreement quite unreasonable in its terms... Not that princes who fail to carry out promises to their disadvantage, which have been exacted from them by their conquerors, escape the dishonour of perjury, as certain doctors argue. These doctors are as ill-informed about the character of the commonwealth as they are about past history, and the true foundations of justice. They treat engagements between sovereign princes as if they were of the same order as contracts and agreements between private citizens. The consequences have been most unfortunate. During the last two to three hundred years this opinion has gained ground, with the result that there has been no treaty, however beneficial, which has not been infringed. It is remarkable that the first legislators and jurists, and the Romans who were models of justice, never thought of such subtleties. For it is very obvious that most treaties of peace are made under constraint, from fear of the victor, or of him who is the stronger party. What fear is more excusable than fear for one's life? Yet the Consul Attilius Regulus, having sworn to the Carthaginians to return, 
knowing that he was going to his death, took refuge in no such subtle excuses. ...

Jurists rightly hold that faith is not to be kept with him who breaks it. But they go further. They allege that by the decree of the Council of Constance it was laid down that one is not bound to keep faith with enemies of the faith. The Emperor Sigismund had pledged his word to Wenceslas, King of Bohemia, and given a safe-conduct to John Huss and Jerome of Prague, and therefore resisted proceedings against them. To satisfy his conscience a number of jurists, canonists, and theologians, especially Nicholas, Abbot of Palermo, and Luigi da Ponte surnamed

Romanus elaborated this opinion, and it was given the backing of a decree published by the Council. John Huss and his companion were executed, though neither the Council nor the Emperor had any jurisdiction over them, and their natural lord, the King of Bohemia, did not give his consent. But no attention was paid to these things. This is no matter for surprise seeing that Bartolus, the first jurist of his age, maintained that one was not bound to keep faith with individuals in the enemy camp who were not responsible leaders. ...

But if faith should not be kept with the enemy, it ought never to be pledged. On the contrary, if it is permissible to treat with the enemy, it follows that one is bound to honour one's engagements to him. This raises the question as to whether it is permissible to treat with pagans and infidels, as the Emperor Charles V treated with the King of Persia... The Kings of Poland, the Venetians, Genoese, and Ragusans, all made similar alliances with them. The Emperor Charles V himself pledged his word to Martin Luther, though he had been denounced as an enemy to the faith in a Papal bull, that he might safely attend the Imperial Diet at Worms in 1519. There van Eyck, seeing that Luther would not renounce his opinions, cited the decree of Constance as grounds for proceeding against him regardless of the pledged word of the Emperor. But there was not a prince present that did not express horror at van Eyck's petition, and in fact the Emperor dismissed Luther with a safe-conduct, and under armed protection. I do not wish to discuss the merits of the decree, but the opinion of Bartolus, and those who maintain that one need not keep faith with the enemy is not worthy of formal refutation, so contrary is 
it to ordinary common sense. ...

There have been no greater exponents of the principles of justice and good faith than the ancient Romans. Pompey the Great treated with sea-rovers and pirates, and allowed them to take refuge in certain towns and territories where they could settle under the authority of Rome. But he was well aware that the pirates had a fleet of nine hundred sail, and access to some five hundred coastal towns and villages. Governors could not reach their provinces, nor merchants carry on their business of trading. War could not be made on such a power without exposing the whole Roman state to danger, whereas its dignity was preserved intact by this treaty. If he had not honoured the agreement he made with them, or the Senate had refused to ratify the treaty, the honour of the Republic would have been smirched, and the glory of Pompey's achievement obscured. In normal circumstances however we do not hold that one should either give or receive pledges where pirates are concerned, for one should have no dealings with them, nor observe the rules of the law of nations where they are concerned ... But once one has pledged one's faith to an outlaw, one should keep the engagement. I can think of no better instance of this than that afforded by the Emperor Augustus. He caused it to be published, to the sound of trumpets, that he would give twenty-five thousand scudi to anyone who could deliver to him Crocotas, leader of the Spanish brigands. Crocotas, hearing of it, presented himself before Augustus and claimed the reward of twenty-five thousand scudi. Augustus ordered that he should be paid, and then granted him a free pardon, in order to give a good example of keeping faith, for in such matters the honour of God and of the Republic is involved...

1. In 1546 Charles brought a Spanish army under the Duke of Alva to Germany to deal with the rebel Princes, which defeated them at the battle of Mühlberg in 1547.

2. Many French armies perished before Naples. This is probably a reference to the disastrous expedition under de Lautrec in 1528, an incident in the war against $\mathrm{Charles} \mathrm{V}$ for Italian territory. 
3. The Imperial army that sacked Rome in 1527.

4. Bodin makes much use of his Storia d'ltalia, published in 1561, for his treatment of Italian politics.

5. An Italian translation of the original Arabic, Descrittione dell' Africa: e delle cose notabile che ivi sono, appeared in 1550, and a French one, Historiale description de I'Afrique, in 1556.

6. The original Spanish appeared in a French translation as Histoire de I'Ethiopie décrite par dom. F. Alvarez en son voyage, 1566 and 1568.

7. B. de las Casas, Brevissima relacíon de la destruycíon lie las Indas, 1552.

8. Frothe was a legendary King of Denmark, who appears in Saxo Grammaticus, Historia Danerum (published 1514) as a pattern of the primitive legislator.

9. Matthias Hunyady, surnamed the Just, for his great work of legal reform. He was a prince of the renaissance, who preferred Italian models in architecture, learning, and legal administration, to the traditional feudal institutions of Hungary. Hence the measure of resistance referred to by Bodin.

10. In chapter III confiscations are discussed, with a view to showing how dangerous and short-sighted is this form of revenue-hunting.

11. This must be Sir Thomas Randolph. He was sent twice to Paris on a special mission, in 1573 and again in 1576. On each occasion he had some private talks with the Duc d'Alençon, Bodin's patron.

12. Much of what Bodin had to say about the distribution of rewards must have been inspired by dislike of developments in France, for Francis I had systematized the traffic in offices, and in 1522 set up a special Bureau des parties casuelles to administer it. Much opposition was offered. Complaints were made already at the Estates of Tours in 1484. The practice was forbidden by the Ordinance of Orleans in 1561 and that 
of Moulins in 1566, and officials on appointment had to take an oath that they had not purchased their offices. This was so flagrantly in defiance of the facts that it was abolished in 1597 . Heritability of office was a consequence.

13. This chapter is largely based on Machiavelli's Arte delta guerra, published in 1521, though characteristically adapted to Bodin's political views.

14. A fifth-century Christian writer, whose book De Gubernatione Dei, a jeremiad on the state of the world, was published in Basel in 1530.

15. To Charles V after his victory at Pavia, 1525.

16. A reference to the agreement made by the Duke of Norfolk on behalf of the Queen with the Scots Lords in rebellion against the regent, Mary of Guise, and in alliance with Knox. It was concluded in February 1560.

17. In 1512 a Papal-Spanish army compelled the re-admittance of the Medici into Florence, whereupon the Republic collapsed. It is true Florence had abandoned the French alliance, but since the French had been driven entirely from Italy earlier in the year, they could have done nothing in any case to save Florence.

18. Charles V brought Savoy over to an Imperial alliance by the marriage of his sister-in-law, Beatrice of Portugal, with the Duke, thus closing the route into Italy hitherto open to the French armies. Francis I thereupon claimed the duchy, overran it and incorporated it in the kingdom of France in 1536.

19. Alexander VI allied with France to facilitate the reduction of the Romagna carried out by Cesare Borgia. Early in 1503 Louis XII prohibited further conquests to him, and at the same time launched an expedition against the Spaniards in Naples. Alexander excused himself from giving assistance, having already opened secret negotiations with the Spanish viceroy. But he died suddenly, and Cesare's power immediately crumbled, later that summer. 


\section{BOOK VI}

The Census and the Censorship[1] [CHAPTER I]

... WE must now discuss the remaining term in our definition of the commonwealth, namely what are those things which are of common interest. The common interest is secured by the administration of the revenue, the domain, rents, revenues, taxes, or imposts and other such charges necessary for the maintenance of the commonwealth. We must therefore first consider the census.

Rightly understood the word census means simply an assessment of each individual's belongings. If we are going to discuss the revenue, we must first enquire into the census, for of all the magistrates in a commonwealth, none are more indispensable than those responsible for it. If the necessity of their function is evident, even more so is its utility, both in establishing the number and quality of persons, and the amount and character of each individual's possessions, but also as a means of disciplining and reprimanding the subject. It astonishes me that so excellent an institution, at once so necessary and useful to the commonwealth, should have been allowed to lapse, seeing that in ancient times all Greek and Latin communities knew it... They spoke of it as a divine institution, and one which preserved the greatness of the Roman Empire, so long as the office retained its prestige. ...

The first advantage to be derived from taking a census relates to the ordering of persons. If one knows the number, age, and status of all one's subjects, one can judge how many can be called upon for military service and how many must be left at home, how many can be despatched abroad to found colonies and how many employed in forced labour upon public works such as fortifications. One can also estimate the supply of food necessary for the needs of the inhabitants of each town, especially useful when one has to provision a town against a siege. None of these things can be done well if one has no idea of the number and distribution of the population.... 
But one of the most important good consequences of numbering the people is that one can find out the standing and the calling of each individual, and how he earns his living. This makes it possible to get rid of those parasites which prey upon the commonwealth, to banish idlers and vagabonds, the robbers and ruffians of all sorts that live among good citizens like wolves among the sheep. One can find them out, and track them down wherever they are.

A declaration of property is as necessary as a census of individuals... Such a survey was made throughout the Roman Empire in order that the burdens which each ought to bear could be fairly assessed. Such a measure is even more necessary now when there are so many more charges than the ancients ever knew. It is of the first importance that every subject should be required to make a return of his property and his revenues. This was done in Provence in 1471. It immediately became clear that one third of the population bore all the burdens of the other two thirds ... Such enquiries reveal the frauds and favours of the tax collectors and assessors, whose duty it is to secure an equal distribution of imposts.

The periodic reformation of abuses was one of the best and most excellent measures that was ever introduced into any commonwealth, and the one which most contributed to the preservation of the Roman Empire. The censors were always elected from among the most upright men to be found in the whole commonwealth, and they endeavoured to the utmost of their powers to inculcate in the subject true sentiments of honour and virtue. They carried out this duty every five years, after they had put the finances in order and farmed out the domain. If at any time they omitted the censorship, as occasionally happened during a long war, one can see at a glance how the morals of the people declined, and the commonwealth fell sick, like a body denied its customary purgations....

They concerned themselves always only with those abuses which did not come before the courts. The magistrates and the people took cognizance of murders, parricides, robberies, assaults, and such like crimes, punishable by the laws. But someone might ask whether it is not sufficient only to punish the crimes and misdemeanours forbidden by law. I would answer however that the law only punishes those misdeeds which 
trouble the public peace, but the most evil men often enough escape the penalties of the law, like strong animals brushing aside spiders' webs. What man is so mistaken as to measure honour and virtue solely by the rules of the law? It is sufficiently obvious that the most detestable vices that poison the whole body politic cannot be punished in the courts. Perfidy, one of the most abominable of vices is never punishable by law. But the censors, said Cicero, were more anxious to punish perjury than anything else. Again, drunkenness, gambling, fornication, and lust can be indulged in without check from the law. Who can remedy this state of things but the censor? One sees also how most commonwealths are afflicted with vagabonds, idlers, and ruffians who corrupt good citizens by their deeds and their example. There is no means of getting rid of such vermin save by the censor.

There is however a more particular reason which makes the censorship more necessary today than ever it was before. In ancient times each head of a family had high, middle, and low justice; as father over his children, as master over his slaves he had sovereign power, so to speak, over life and death, without appeal. The husband had such authority over his wife in four respects, as we have shown in its proper place. But now that this condition of things no longer obtains, what justice can one expect from the impiety of children towards their parents; from the ill-regulated relations of married people, or contempt for masters? How often do we see daughters sold or dishonoured by their own parents, so that often enough they prefer to be cast off than to be married to the husband chosen for them? There is no possible remedy save in the establishment of a censorship.

I am not here concerned with the question of reverence towards God, which should be the first and principal care of every family and every commonwealth. This has always been the concern of popes, bishops, and ministers of religion, to whom magistrates ought always to give every assistance. For though the law of God commands that everyone should attend divine worship at least at the three great festivals of the year, one finds a great number who never do so at all. This neglect of religion encourages the insidious growth of the detestable sect of atheists. They have nothing but blasphemies on their lips, and despise all laws equally, whether human or divine. From this state of affairs 
follows an infinity of crimes such as murder, parricide, treason, perjury, adultery, and incest. For one cannot expect princes and magistrates to succeed in making those of their subjects who trample all religion underfoot amenable to their own laws. This is a matter for ministers and censors, who can appeal to divine laws where human laws have lost their force. As Lactantius said those actions which fear of the laws prevent are acts of violence, not sins. The laws can punish crimes but cannot stir the conscience'.

One sees how much the education of young people is neglected nowadays, though it should be one of the principal concerns of every commonwealth. The young are tender plants, and must be raised with great care. But what should be a matter of public policy is now left to each individual's private discretion, and each does as he chooses, one one thing and one another... All these things should depend on the care and attention of censors, whose first concern should be to provide for the education of the young, and teachers for this purpose. ...

But censors should not be given any powers of jurisdiction, for their activities should not be encumbered by legal proceedings. The Roman censor had no jurisdiction, but a word, a look, a stroke of the pen from him inspired a more lively dread than all the sentences and penalties of the magistrates. ...

It is not my intention to discuss the justification of ecclesiastical jurisdiction. But such as it is, there is a danger of it disappearing and with it the Church's power of censure, as a result of its excessive use. Such censure used always to be remarkably effective. The Druids of old, who were sovereign judges and high priests in Gaul, excommunicated kings and princes who would not obey their injuctions. Among Christians ecclesiastical censure has maintained discipline and good morals for many centuries. Tyrants have been made to tremble before it, and kings and princes have been brought to reason. Their crowns have been struck from off their heads and their sceptres out of their hands. Kings have been constrained to make peace or war, to reform their way of living, or amend their laws. History is full of such occasions. The outstanding instances are the censuring of Theodosius by St. Ambrose, and of Lothar by Nicholas I, and the excommunication of Louis VII of France by 
Innocent. ...

Priests, bishops, and popes have always claimed the censorship of morals and religion, as a matter not pertaining to judges and magistrates, except by way of executing sentence. But elders and overseers have exercised the same prerogative in many places, a very necessary concession where there are no censors, both for regulating the morals of the people and superintending them diligently, and to support the authority of pastors, bishops, and ministers, for they cannot be too highly honoured and respected for the dignity and responsibility of their office. God in His wisdom so provided, appointing ministers, and giving the prerogative of honour over all the rest to the tribe of Levi, and among the Levites, to the house of Aaron who were all priests, giving them the tithe of all cattle, harvests, and inheritances, together with many honours and privileges. By an article of the divine law, the man who disobeyed the High Priest was adjudged worthy of death.

Those who wish to diminish the estate of bishops, ministers, and overseers, and deprive them of their powers of ecclesiastical censure, their possessions and their privileges, to trample them underfoot, dishonour God, and destroy all religion. This important question was in part the reason why the chief minister of Lausanne left the town, for the governing bodies of the confederate states would not submit to the censorship of the elders. One must in that case institute special censors. The governing body of Geneva has however reserved this prerogative to bishops, ministers, and elders. They have corporate rights, and can, in their consistory, censure morals. They have no jurisdiction, or power of compulsion, or of execution, either themselves or in the persons of the public officials. But in case of disobedience they excommunicate. This involves the most serious consequences, for the excommunicate, after a certain lapse of time, is liable to a criminal prosecution before the magistrates, by the Inquisitor of the faith. There is the same system in the Catholic Church, but proceedings are not there so expeditious. ...

I leave it to wiser heads then mine to decide whether one should divide temporal censorship in matters touching morals and other matters remarked on, from ecclesiastical censorship, or to unite the two. But it 
is better to let bishops and ministers exercise both than to deprive them of such powers altogether, and so deny the commonwealth that which is most necessary to its welfare. One sees commonwealths that have such an institution nourish in laws and morals. Licence, usury, excesses of all sorts are prevented; blasphemers, ruffians, idlers, expelled. One cannot question that commonwealths that employ these measures of censure are lasting, and fortified by all the virtues. But once the censure is neglected, laws, virtue, and religion are despised, as happened in Rome a short time before the Empire collapsed in ruins. ...

\section{The Revenues [CHAPTER II]}

... THERE are, generally speaking, seven sources of revenues which include all the possible sources that one can well imagine. The first is the public domain, the second the profits of conquests, the third gifts from friends, the fourth tribute from allies, the fifth the profits of trading ventures, the sixth customs on exports and imports, and the seventh taxes on the subject. The first, which is the domain, appears to be the most defensible and the most reliable of all sources of income. We read that all ancient kings and legislators who founded commonwealths or planted colonies, besides public buildings such as roads, temples, and theatres, assigned certain lands to the commonwealth which belonged to all in general, and the se they called common lands. Other lands were farmed or leased to private individuals for a term of years, or in perpetuity, and the rents of these lands were paid into the treasury for the discharge of the expenses of the commonwealth. We read, for instance, that Romulus, founder of Rome and the Roman Republic, divided the whole territory into three parts, assigning one third for the upkeep of the Church, a second as the public domain, and the rest was divided among private individuals. ...

In order that princes should not be constrained to burden their subjects with imposts, or devise excuses for confiscating their possessions, all kings and people have taken it for a universal and unchallengeable rule that the public domain should be sacred, inviolable, and inalienable, either through contract or prescription. Kings therefore even in this kingdom, issuing letters patent for the recovery of domain, declare that on their accession to the throne they took an oath never to alienate the 
domain. If it has been alienated, even according to the proper legal forms, and in perpetuity, it nevertheless remains susceptible of recovery, so that prescription of one hundred years, which normally constitutes a title to possession, does not hold for the domain. Edicts, judgements, and ordinances on the subject are sufficiently familiar in this kingdom, not only directed against private citizens, but even against Princes of the Blood who have been deprived of domainal lands after a hundred years' prescription. This is not a rule peculiar to this kingdom, but is a custom binding on the Kings of Spain, Poland, and England, for they also are required to take an oath against alienating the domain. The rule is also observed in aristocracies and popular states ... It is therefore never permissible for sovereign princes to misappropriate the revenues from the domain. They have not the right of usufruct, but simply of administration, and they must, once the expenses of maintaining the commonwealth and their own estate are met, reserve the rest for some public necessity ...

It is to be observed however that the conservation of the domain is much better secured in a monarchy than in an aristocracy or a popular state. There the magistrates and collectors of taxes are only concerned to convert what belongs to the public to their own private advantage, and each thinks only either of gratifying his friends, or of winning popular favour at the public expense. ...

The second means of replenishing the treasury is by the profits of foreign conquests ... When William the Conqueror subjugated the realm of England, he declared the whole country in general, and the estates of each particular person forfeit to him by the conventions of war, and he treated the English simply as his tenants. The Romans were more civilized and farseeing in this respect, for they despatched colonists for whose benefit a proportion only of the land was confiscated. In this way they got rid of the indigent, disorderly, and idle elements among their own people, and at the same time planted settlements among the conquered people. Subsequent intermarriage bred mutual trust, so that the conquered came to submit to Rome willingly. The world was thus populated with colonies of Romans to the enhancing of their reputation for justice, wisdom, and power. Nowadays most victorious princes establish garrisons of professional soldiers, who think only of 
pillaging and so exasperate the subject population into revolt. If Roman examples had been followed when the French conquered Naples and Milan, these cities would still be obeying our kings. ...

The third means of increasing the revenues is by gifts, furnished by friends or subjects. There is not much to be said about this, for it is not a certain source of income. Few princes offer such gifts, and still fewer receive them without returning some equivalent... As to gifts offered by subjects, such as the Romans called oblations, one very seldom hears of them these days, for so-called free gifts are for the most part compulsive....

The fourth resource is the pension received from an ally. These are paid in time of peace as well as war to secure defence or protection against enemies, or aid and assistance of any sort at need, according to the terms of the treaty... By the terms of the treaties of alliance between the King of France and the Swiss, the king gave to each Canton a pension of one thousand livres to secure peace with them, and a pension of two thousand livres for their active co-operation, besides extraordinary payments. He also undertook to pay the expenses in war, and the salaries of those who entered his household, or acted as his bodyguard. By these terms it was clear that the Swiss were the king's pensioners. ...

The fifth expedient is for the prince or the signory to engage in commerce ... Everyone knows how for the last century, ever since the discovery of the gold mines and other riches of Guinea, and of the spices of Calicut and the East twelve years later, the Kings of Portugal have engaged in trade with such success that they have made themselves masters of the best harbours of Africa, occupied the island of Ormuz in the teeth of the opposition of the Shah of Persia, and subjected a great part of Morocco and Guinea ... But of all forms of traffic in which a prince can engage, the sale of honours, offices, and benefices is the most pernicious and sordid, as I have already said. ...

The augmentation of the revenue by charging the merchants who import and export commodities is one of the oldest and commonest customs of commonwealths. It is founded in equity, for it is reasonable that the man who wants to make his profit out of the subjects of another should 
pay some duty to the prince or the people, as the case may be... One should go upon the principle of increasing the export duties, payable by foreigners, on things they cannot well do without, for this both increases the revenues, and helps the subject. The customs on raw materials imported from abroad should be lowered, and that on manufactured articles increased, and their import from abroad, or the export from this country of such raw materials as iron, hides, steel, wool, linen thread, raw silk, and such like should be prohibited altogether. In this way the subject makes his profit on the manufactured article, and the prince on the customs. Such a prohibition was imposed in 1563 by Philip II of Spain, as an act of retaliation against a similar measure of the Queen of England three years earlier. ...

The last method of raising revenue is to tax the subject. One should never have recourse to it till all other measures have failed, and only then because urgent necessity compels one to make some provision for the commonwealth. In such a case, seeing that the security and defence of each private citizen depends on the preservation of the common good, each individual must be prepared to assist in the matter. In such a crisis, taxes and impositions are most just, for nothing is more just than that which is necessary, as a Roman senator once observed. Nevertheless, in order to secure that an extraordinary tax, imposed in time of war, should not be continued in peace time, it is better to impose it in the form of a forced loan. Moreover the money comes in more readily when the payer hopes both to receive his money back again sometime, and to enjoy the distinction of having made a contribution ... Louis IX was the first to levy a general tax, as President Le Maître has shown. The President did not add however that it took the form of an extraordinary subsidy in time of war, justified by necessity, and never became part of the ordinary revenues. On the contrary, St. Louis in his testament addressed Philip, his elder son and successor in these words: 'Be devout in the service of God; be merciful and charitable at heart to the poor, and comfort them with your assistance; keep the good laws of your kingdom; do not levy taxes or impositions on your subjects, unless urgent and evident necessity forces you to it, and for some just cause, but not arbitrarily. If you do otherwise, you will not have the reputation of a king, but of a tyrant. ...' 
It was declared by the estates of this realm, in the presence of King Philip of Valois in the year 1338, that he could not levy any tax on his people without their consent ... This rule has always been observed, and is also a well established custom in Spain, England, and Germany. At the Estates of Tours, assembled in the time of Charles VIII, Philippe de Comines declared that there was nowhere a prince who had power to levy taxes on his subjects, nor could he acquire such a right by prescription, without their consent. ...

If anyone asks what form taxes should take which are to redound to the honour of God, and the profit of the commonwealth, to the satisfaction of men of substance, and the relief of the poor, I suggest that they should be levied on those commodities which corrupt the subject. Taxes should be raised on luxuries and ornaments of all sorts, perfumes, cloth of gold and silver, silk, lace, fine tissues, gold and silver en amel. They should also be charged on all unnecessary articles of clothing, and on scarlet, crimson, and cochineal dyes and so forth. One should not prohibit the sale of these articles. Men are so made by nature that they find nothing more attractive than that which is strictly forbidden. The more superfluities are denied to them, the more earnestly are they desired, especially by giddy and unstable natures. It is better to make such things so expensive by heavy taxes that only the very rich and indulgent can afford them....

There is also the problem of the right use of the public revenues. The upkeep of the king's household should first be provided for.

That secured, and the army and the officers of the crown paid regularly, all poor subjects will benefit. If funds then permit, part should be employed in constructing fortifications in strategic positions on the frontiers, making roads, building bridges, chartering ships, erecting public buildings, founding colleges of learning and of honour. This work of upkeep is not only necessary, but it redounds to the profit of the whole commonwealth. Crafts and craftsmen are encouraged, and the necessities of the poor relieved. Moreover the unpopularity of taxation is mitigated when the ruler sees to it that the money he takes from his subjects is used for the benefit of all in general, and each in particular. ... 
A Comparison of the three Legitimate Types of Commonwealth, Popular, Aristocratic, and Monarchical, concluding in favour of Monarchy [CHAPTER IV][2]

WE have now discussed the commonwealth fairly fully from all points of view. It remains to draw our conclusions, that is to say to consider the advantages and disadvantages of each type, and then pronounce on the best. This can only properly be done after one has discussed all aspects of the commonwealth, both general and particular ... Tyranny in a prince is evil, but it is even worse where many rule. As Cicero says, there is no more remorseless tyranny than that of the people. All the same it is a condition of things to be preferred to anarchy, where there is no form of a commonwealth whatsoever, and where none can command, and none are obliged to obey. Let us avoid such evil conditions as these, and consider which is the best of the three legitimate forms of commonwealth, that is to say a popular state, an aristocracy, or a royal monarchy. In order to make my conclusions quite clear, I shall first set out the arguments for and against each type.

In the first place it can be argued that the popular state is the most to be esteemed since it aims at an indifferent and equal rule of law, without favour or exception of persons. In such a state civil constitutions are brought into conformity with the laws of nature. In equalizing men it follows the order of nature, under which riches, estates, and honours are not attributed to one more than to another. Similarly, in a popular state all enjoy equality in respect of goods, honours, and legal rights, without any being privileged or entitled to prerogatives... For instance, when Lycurgus converted the monarchy into a popular state, he burnt all records of debts, forbad the use of gold or silver, and divided the land into equal lots. It gave him great satisfaction to see an equal harvest gathered in from each holding. By such means the two most ruinous plagues of the commonwealth, the avarice of some and the arrogance of others, were avoided. By such means also he got rid of all thefts and robberies, disorders, libels, parties and factions, for such cannot develop where all are equal, and no one has the advantage over another. Again, if friendship is the necessary foundation of human society, and if equality is a condition of friendship, since there is no equality except in a popular state, it 
follows that this is the best form of the commonwealth, and ought to be preferred to all others. In it is to be found natural liberty, and equal justice for all, without fear of tyranny, cruelty or oppression, and the charms of a social intercourse open to all alike, which would seem to secure to men that felicity that nature intended for them. But there is an even stronger argument to prove that the popular state is the best, most worthy and most perfect form, and that is that democracies have generally produced the men who have most excelled in arms and in justice, the greatest orators, jurists, and craftsmen. In other commonwealths, factions among the ruling class, or the king's jealous regard for his own honour and glory, have discouraged subjects from attempting anything outstanding. And finally, it would seem that a popular state alone bears the true mark of a commonwealth. In it everyone partakes in the common good, having a share in the common property, the spoils of war, public honours, and conquered territory, whereas in an aristocracy a handful of the upper class, in a monarchy a single person, appear to convert what should be enjoyed in common to their private advantage. Briefly, if what is most to be hoped for in the commonwealth is that magistrates should be subject to the laws, and the subjects to the magistrates, this seems best secured in a popular state where the law is lady and mistress of all.

These are the principal arguments in favour of the popular state. They appear conclusive, but in effect are no better than spiders' webs, glittering, subtle, and fine-drawn, but of no strength. In the first place, there has never been a commonwealth in which it has been found possible to preserve equality of property and of honours. With regard to honours, such equality is contrary to the laws of nature, for by nature some are wiser and more inventive than others, some formed to govern and others to obey, some wise and discreet others foolish and obstinate, some with the ascendancy of spirit necessary to guide and command others, some endowed only with the physical strength to execute orders. As to natural liberty, which is so much cried up in the popular state, if such a condition were realized anywhere, it would preclude the existence of any magistrates, laws, or form of state, since such presuppose inequalities. As for the common good, it is quite clear that there is no form of commonwealth where it is less regarded than in a popular state. ... 
All those who have discussed the subject are agreed that the end of all commonwealths is the encouragement of honour and virtue. But a popular state is hostile to men of reputation. The preservation of a popular state, according to Xenophon, depends on the promotion of the most vicious, and least worthy, to all honours and offices. If the people are so ill-advised as to bestow honourable charges and dignities on upright and virtuous men, they lose their ascendancy. Honest men advance others like themselves, and such people only ever form a small handful of the community. The bad and the vicious, who are the great majority, are denied advancement, and gradually deprived and superseded by just and upright judges. In this way the best men come to control the state, and take it out of the hands of the people. For this reason, said Xenophon, the Athenians always gave audience to the most evil, knowing full well that they would say those things which were welcome and useful to the wicked men who made up the majority of the people. 'This is why', he said 'I blame the Athenians, for having chosen the worst form of commonwealth there is, but having chosen it, I commend them for conducting their affairs the way they did, that is to say for resisting, persecuting, and banishing the noble, the wise, and the virtuous, and for advancing the impudent, vicious, and evil. For the vice', he said, 'which you denounce so severely is the very foundation of the popular state.' As for justice, he thought that they cared nothing for it. They were only anxious to secure the profits of selling to the highest bidder, and to find means of ruining the rich, the noble, and the incorruptible. Such men they harassed without any justification, because of the hatred they felt for a type quite contrary to their own natural temperament. For this reas on a popular state is always the refuge of all disorderly spirits, rebels, traitors, outcasts, who encourage and help the lower orders to ruin the great. The laws they hold in no esteem, for in Athens the will of the people was law. Such was Xenophon's judgement on the Athenian republic, which was the best-ordered of any popular state of its times, and he did not see how it could be in the least changed if the people were to be continued in authority ... Those who praise the Roman Republic to the skies should remember the disorders and evil commotions to which it was a prey....

Someone may quote against me the case of the Swiss republics. There you have admirable popular states which have nourished for upwards of three 
hundred years. They have not only rid themselves of tyrants, but helped to free their neighbours too. But I think the reason is first that a popular form of government is suited to the temperament of the inhabitants, as I said before, and second, that the most restless and intractable go abroad and take service with foreign princes. Those that remain at home are the more peaceable and manageable, and have little desire to concern themselves with politics. ...

The ability to command cannot be made equal, as the citizens of popular states desire, for we all know that some have no more judgement than brute beasts, while in others the illumination of divine reason is such that they seem angels rather than men. Yet those who want to make all things equal want to give sovereign authority over men's lives, honour, and property, to the stupid, ignorant, and passionate, as well as to the prudent and experienced. In popular assemblies votes are counted, not weighed, and the number of fools, sinners, and dolts is a thousand times that of honest men....

I have said all this to bring out the disadvantages of the popular state, and to induce a little reason in those who would incite subjects against their natural prince, in the illusory hope of enjoying liberty under a popular government. But unless its government is in the hands of wise and virtuous men, a popular government is the worst tyranny there is.

Let us now see whether aristocracy is better than the others, as some think. If we adopt the principle that the mean between two undesirable extremes is the best, it follows that if such extremes are to be avoided, the mean is aristocracy, where neither one nor all have sovereign power, but a small number ... There is another argument of equal weight in favour of aristocracy, and that is that the right of sovereign command ought, by the light of natural reason to go to those most worthy of it. But worth must be identified with virtue, nobility, or riches, or all three. Whether one thinks it should be any one of these, or a combination of all three, the result is still an aristocracy. For the well-born, the rich, the wise, the worthy are always the minority among the citizens, wherever you go. Natural reason would thus seem to indicate that an aristocracy where a group of 
citizens, and that a minority, govern, is the best. More properly speaking it is the state in which only the most worthy are admitted as rulers. One can even argue that this means that government should be in the hands of the wealthy, since they are most concerned for the preservation of the commonwealth. They are interested because they undertake much heavier burdens than the poor, who having nothing to lose by it, back out of responsibility at will. For this reason Q. Flaminius bestowed sovereign power on the richest towns in Thessaly because, as he said, they had most interest in preserving the state. Moreover it would seem that aristocracy is necessarily the best state, for in either a popular state or a monarchy, though in appearance sovereignty belongs either to the people or the king, in effect they are compelled to leave government in the hands of the senate or the privy council which deliberate, and often enough determine, all important affairs of state. In fact, all types are in reality aristocratic. If the people or the king is so ill-advised as to govern in any other way than through the advice of a wise council, ruin must inevitably follow.

Nevertheless all these reasons do not seem to me to add up to a sufficient total. The golden mean that everyone is looking for is not secured by a numerical calculation, but in the sphere of morals means the rule of reason, as all the philosophers agree ... The same disadvantages that we have noticed in the case of popular states characterize aristocracies, as a result of the multiplication of rulers. The greater the number of those that rule, the more opportunities are there for faction, the more difficult it is to arrive at any agreement, and the more irresponsible are the decisions taken. In consequence the aristocracies which have been the most lasting and the most stable have been those that have been ruled by the fewest in number. The thirty in Sparta, and the twenty or so in Pharsalia long maintained their authority. Others have not been so lasting ... It is very difficult for a handful of rulers to preserve their authority over a whole people who have no share in the honours of office, especially as the ruling class generally despise the populace, and the poor feel a deadly hatred of the rich. On the least disagreement between members of the ruling class -inevitable if they are naturally enterprising and aggressive -- the most factious and ambitious go over to the people, and subvert the aristocratic form of the government. This has been the most frequent 
cause of the ruin of seigneuries such as those of Genoa, Siena, Florence ... In the state of fear in which they live, the ruling class do not dare to train their subjects to arms. They cannot go to war without being in danger of losing their authority should they lose a single battle. They cannot secure themselves against their enemies, and live in perpetual dread of defeat. A popular state is not exposed to such dangers, since everyone has a share in power. Therefore an aristocracy is in danger not only from foreign enemies, but also from their own subjects whom they must satisfy, or hold down by force. It is extremely difficult to satisfy them without admitting them to the estates, and impossible to concede honourable charges to them without converting the aristocracy into a popular state. As for holding them down by force, it offers no security, even when it can be done. It means inspiring fear and mistrust in those whom one should win over by services and patronage, otherwise the most insignificant foreign attack against the state, or the least disagreement within the ruling class, means that the people take up arms in the hope of shaking off their yoke. For this reason, in order to preserve their aristocratic form of state, the Venetians threw open certain minor offices to the people, intermarried with them, created a state debt to give them a vested interest in the regime, and totally disarmed them....

It is obvious then that the principal foundation of an aristocracy is the preservation of concord within the ranks of the ruling class. If they can maintain their solidarity, they can maintain their government much better than can the people. But if they allow factions to develop, there is no form of government more difficult to maintain, for the reasons I have given, especially if it is a military aristocracy, for nothing is more contrary to the temper of such than the preservation of peace. It is not to be wondered at that the aristocracies of Venice, Ragusa, and Lucca have endured for so many centuries, for they renounced all armed enterprises, and occupied themselves exclusively with commerce and banking. ...

There remains monarchy to be considered. All great men have preferred it to any other form. Nevertheless it is beset by many dangers, for even when the succession of a new king means a change from a bad king to a good, or from a good king to a better, there is necessarily a change in 
the seat of sovereignty, and such a change is critical in all kinds of commonwealth. It is a matter of common experience that when a new prince succeeds, all sorts of new plans, new laws, new officials, new friends, new enemies, new customs, new social habits spring up. Most princes are pleased to introduce novelties of all sorts, just to get themselves talked about. This often entails the most serious consequences, not only for their individual subjects, but for the whole body of the commonwealth. Even when a prince is the wisest of men, and does not behave in this manner, the alliances and peace settlements made by his predecessor are dissolved by his death. That being so, neighbouring princes take up arms, and the stronger attacks, or dictates terms to the weaker. This cannot happen to the undying sovereigns of popular and aristocratic states, for they can make perpetual alliances ... The other drawback to monarchy is the danger of civil war between aspirants to the crown, especially where it is elective. This has often brought ruin on the state. Even when the crown is hereditary there is no little danger when there is a dispute between claimants of the same degree of relationship. Assassinations follow, and divisions among the subjects, and often the legitimate heir is expelled by the man with the worse title. We have had only too many examples of this before our eyes. Even when the succession is not in question, if the king is under age there are conflicts about the regency, either between the Queen Mother and Princes of the Blood, or among the Princes themselves. When God intended to punish the sins of the people, he threatened them with women and children as rulers ... Even if a people enjoys the greatest blessing it can hope for -- and this seldom happens -- and the prince on his accession is of mature years and experienced in affairs, nevertheless the enjoyment of sovereign power too often has the unhappy effect of making fools of wise men, cowards of brave ones, wicked men of honest. There have been too many instances for any examples to be necessary....

Such are the dangers inherent in the monarchical form of government. They are great enough. But they are not so great as those which threaten an aristocracy, and even less than those that threaten popular states. Most of these dangers are avoided when the monarchy passes by hereditary succession, as we shall show in its proper place. Sedition, faction, civil war are a perpetual threat to all types of commonwealth, and the struggle for power in aristocracies and popular states is frequently 
much more bitter than in a monarchy. In a monarchy conflict over office and over political power only breaks out openly on the death of the prince, and then not very often.

The principal mark of a commonwealth, that is to say the existence of a sovereign power, can hardly be established except in a monarchy. There can only be one sovereign in the commonwealth. If there are two, three or more, not one of them is sovereign, since none of them can either impose a law on his companions or submit to one at their instance. Though one can imagine a collective sovereign power, vested in a ruling class, or a whole people, there is no true subject nor true protector if there is not some head of the state in whom sovereign power is vested, who can unite all the rest. A simple magistrate, not endowed with sovereign authority, cannot perform this function. Moreover if the ruling class, or the people are, as often happens, divided, the dispute can only be settled by force, and by one taking up arms against another. Even when the majority is agreed, it can easily happen with a people that the minority have considerable resources, and choose a leader whom they force upon the majority, and so carry all before them. We have plenty of evidence of the difficulties that arise in aristocracies and popular states when there is a divergence of opinion and diverse views taken by the magistrates. Some want peace, some war; some want this law, some another; some this president, some that, some alliance with the King of France, others with the King of Spain ... Again, in a popular or aristocratic state numbers always carry the day. But the wise and virtuous are only a small minority in any community, so that for the most part the more reasonable and discrete are compelled to give way to the majority, at the dictation of some impudent tribune or envious demagogue. But the sovereign monarch can seek the support of the smaller and wiser part, and choose expert advisers, experienced in affairs of state. In popular and aristocratic states, wise and foolish alike have to be admitted to the estates and to the councils.

It is impossible for a people or an aristocracy themselves to issue sovereign commands, or give effect to any project which requires a single person to undertake it, such as the command of an army and such like matters. They have to appoint magistrates or commissaires to this end, and these have neither the sovereign power, the authority, nor the 
majesty of a king. Whatever powers they have in virtue of their sovereignty, when popular or aristocratic states find themselves engaged in a perilous war either with a foreign enemy, or with one another, or in difficulty in bringing some overmighty subject to justice, in securing public order in times of calamity, in instituting magistrates, or undertaking any other weighty matter, they set up a dictator as sovereign ruler. They thereby recognize that monarchy is the sacred anchor on which of necessity, all must in the last instance rely. ...

There are many who make the mistake of thinking that an aristocracy is the best kind of state because many heads better than one in all matters requiring judgement, experience, and good counsel. But there is a great difference between counsel and command. It is better to take the opinion of many than of one in all matters of counsel, for it is said that many understand better than one. But for taking a decision and issuing an order, one is always better than many. He can think over the advice that each has given and then reach a decision without being challenged. Many cannot achieve this so easily. Moreover ambition is unavoidable where there are several rulers sharing power equally, and there are always some who would rather see the commonwealth ruined than recognize that another was wiser than they. Others recognize it well enough, but pride, and fear for their reputation, prevents them from changing their opinions. In fact it is necessary that there should be a sovereign prince with power to make decisions upon the advice of his council. It is impossible that the commonwealth, which is one body, should have many heads, as the Emperor Tiberius pointed out to the Senate.

It is said that new princes run after novelties. If it is true that some, in order to make their power felt, published new laws with and without reason, this evil is much more characteristic of popular and aristocratic states. Magistrates who are in the place of kings in such commonwealths, but have only a very short term of office, are consumed with anxiety lest their year of authority should pass by without anything having been accomplished for which they could be well or ill spoken of. More laws were published in Rome and Athens than all the rest of the world put together. From jealousy of their predecessors magistrates continually undid their work, and always to get credit for themselves, and to steal honour from their compatriots at the expense of 
the commonwealth. In order to circumvent such dangerous and insatiate ambition, in popular and aristocratic states the name of the magistrate proposing it should not be prefixed to a law, as was the practice in Rome and Athens. This was the cause of such an excess of law-making.

It is not true to say that alliances and treaties of peace perish with the prince who made them. This does not always happen, for the terms may include a clause relating expressly to the life-time of the prince, and for a certain number of years after his death. In the treaties between the Kings of France and the Confederates it is always laid down that the alliance shall continue for the lifetime of the prince and for five years after his death. Moreover as we have already said, it is better that alliances should not be perpetual. For this reason even aristocracies and popular states frequently limit their alliances to a certain term of years. ...

There is no need to insist further that monarchy is the best form, seeing that the family, which is the true image of the commonwealth has only one head, as we have shown. All the laws of nature point towards monarchy, whether we regard the microcosm of the body, all of whose members are subject to a single head on which depend will, motion, and feeling, or whether we regard the macrocosm of the world, subject to the one Almighty God. If we look at the heavens we see only one sun. We see that even gregarious animals never submit to many leaders, however good they may be ... Moreover we may observe that all the peoples of this world since the most ancient times adopted the monarchical form of commonwealth by the light of natural reason. One hears nothing of aristocracies, much less of popular states among the Assyrians, Medes, Persians, Egyptians, Indians, Parthians, Macedonians, Celts, Gauls, Scythians, Arabs, Turks, Muscovites, Tartars, Poles, Danes, Spaniards, English, Africans, and inhabitants of Persia. Even the ancient inhabitants of Greece and Italy were ruled by kings alone until they were corrupted and degraded by ambition. It is a matter of wonder that the popular state of the Romans and the aristocracies of Sparta and Venice have endured for so long as four hundred years. There is reason to wonder how it came about that two or three republics among a hundred others managed to survive for several centuries, seeing that their form is contrary to the course and order of nature. But no one is surprised 
to see many great and powerful monarchies maintain themselves in all their glory for a thousand or twelve hundred years, for they are ordered according to the laws of nature. ...

It seems to me that for these reasons, and for others that one need not go in to, it is clear that of the three types of commonwealth monarchy is the most excellent. Among those that are not so well regulated, democracy is the most perverted. The true monarchical state, like a strong and healthy body, can easily maintain itself. But the popular state and the aristocracy are weak and subject to many ills, and must be supported by strict diet and discipline. It is not however always in the power of even wise men, and those practised in affairs of state, either to choose the best or avoid the worst ... The statesmen, the philosophers, theologians, and historians who have praised monarchy above every other form of state, have not done so to flatter the prince, but to secure the safety and happiness of the subject. But if the authority of the monarch is to be limited, and subjected to the popular estates or to the senate, sovereignty has no sure foundations, and the result is a confused form of popular state, or a wretched condition of anarchy which is the worst possible condition of any commonwealth. These matters should be weighed carefully, and the deceptive arguments of those who would persuade subjects to subordinate the king to their own pleasure, and impose laws on him, should be exposed as leading to the ruin not only of the monarchy, but of the subject. ...

The lot of the subject of a powerful king ruling a wide domain is a happy one if he makes any attempt to rule justly. Aristocracy is better suited to a small state, but is always preferable to a weak tyranny. There are eighteen aristocratic or popular republics in the Swiss Confederation, without counting the Grisons, though the distance from Geneva to Constance is only two hundred and forty thousand paces, and that from the Alps to the Jura, one hundred and sixty thousand paces. A good deal of this area is besides barren rock. Yet their inhabitants have lived happily enough for a very long time. But if such a people begin to covet the territories of their neighbours, they risk losing their own. On the other hand the more extensive a monarchy, the more nourishing it is, and the better assured are its people of peace and contentment. If it breaks up into democracies and aristocracies, or into 
a number of petty tyrannies, its people fall a prey either to tyranny, or civil disorders, or perpetual struggles with their neighbours....

That in a Royal Monarchy Succession should not be by Election nor in the Female Line, but by Hereditary Succession in the Male Line... [CHAPTER $\mathrm{V}]$

IT is not sufficient to say that a royal monarchy is better than cither democracy or aristocracy if one does not add that the monarchy should devolve undivided, and by right of inheritance, on the next male heir. Just as monarchy is to be preferred to any other form of commonwealth, among monarchies those that pass by right of inheritance to the next heir in the male line are more ordered and stable than those that pass by election ... However it is not only simple people and those who have little understanding of politics, but even those who are experienced in such matters, who are led astray by considering all the advantages, and ignoring all the many absurdities and difficulties that arise from some particular line of action. Even Aristotle thought that kings should be elected, and stigmatized as barbarians all those peoples who are ruled by hereditary kings. ...

But all elective monarchies are constantly menaced by the danger of a relapse into anarchy on the death of each king. The state is left without a ruler or regular government, and is in imminent danger of destruction, just as a ship without a master is liable to be wrecked by the first wind that blows. During such an interregnum, thieves and murderers are encouraged to rob and kill as they please, having little fear of punishment. This is the usual state of affairs, for instance, on the death of a Pope ... As to the civil wars of the Romans, and in more recent times of the Germans, incidental to the elections to the Empire, their histories are full of nothing else. Anyone may read therein the hideous story of looted cities, and of whole provinces pillaged and ravaged by one side or the other.

There is another disadvantage, and that is the danger that the public domain will be converted to private ownership. This has happened to the temporalities of the Holy See, and to the Empire. Elected rulers, knowing they cannot pass on their position to their sons, endow them 
from the public resources by gifts or sales ... Charles IV not being able to find the hundred thousand crowns promised to each Elector, sold them imperial rights to procure the election of his son as Emperor, the same who was shortly after dethroned by those same Electors.

There is another factor to be considered. A man of mean extraction, suddenly advanced to the first rank of honour, thinks himself a god on earth. As the wise Hebrew remarked, no ruler is more unendurable than the slave turned master. Moreover the love of a father for his son is so strong that he would subvert heaven and earth, if he could, if he might thereby leave the crown to his son.

But these are not the most serious difficulties. In the choice of a prince, the election must fall either on a foreigner or a native. In an elective monarchy each aspires to the crown, and among so many equals serious factions cannot be avoided, and these divide the whole population into mutually hostile camps. Even if the candidates are not equal in ability, or in resources, they consider themselves to be so, and are reluctant to obey one of themselves. Tacitus says that the ruling class in Armenia would not choose a native king, and in Poland recently the senate disqualified all natives of the country from competing, as I learned from Baron Horbort, one of the thirteen ambassadors from Poland[3]... As for foreign princes, they always endeavour, as far as they are able, to subvert the laws, customs, and religion of the country. For this reason God forbad His people to choose an alien ruler. Wherever there is an election, and the way is open to a number of competitors, if recourse is had to force, it is always the most unscrupulous and cunning, or the boldest who is willing to risk everything for the chance of success, who prevails. If by any chance an honest man is elected, his life is in perpetual danger from each of his powerful rivals. During the three hundred and sixty years that the crown in Germany has been elective, eight or nine Emperors have been killed or poisoned, as was William of Holland, Rudolf, Albert, Henry VII, Frederick II, Louis of Bavaria, and Charles IV, not counting those who have been shamefully ousted from the imperial throne....

Therefore even if it were possible that good and virtuous princes were invariably elected, the difficulty of securing this, and the dangers 
that threaten on all sides, should be sufficient to deter men from allowing monarchy to become elective, so long as it is possible to observe a rule of succession ... Any law of succession however will not do equally well. It must be that of primogeniture in the male line, the right of the first born son to bear his father's name, to the succession. The order of nature requires that the eldest should come next after his father, and the rest follow each in order. The eldest is therefore to be preferred to the others. One may regard this as a law of nature, and it has been commonly observed among practically all peoples.

I have said that the crown ought to descend in the male line, seeing that gynecocracy is directly contrary to the laws of nature. Nature has endowed men with strength, foresight, pugnacity, authority, but has deprived women of these qualities. Moreover the law of God explicitly enjoins that the woman should be subject, not only in matters concerning law and government, but within each particular family. The most terrible of maledictions uttered against the enemy was that they might have women to rule over them. Even the civil law forbids to women all charges and offices proper to men, such as judging, pleading, and such-like acts. This is not only because of their lack of prudence, but also because vigorous action is contrary to the sex, and to the natural modesty and reserve of women....

But dangerous as elections to the crown are, for the reasons we have already given, should there be a failure of heirs male, this expedient is to be preferred to the succession of women, for that means outright gynecocracy in defiance of natural law. Should the sovereign princess marry, as she must do to secure the succession, she must marry either a subject or a foreigner. If a subject, it is a great abasement for a princess to marry one other servants, seeing that the greatest sovereign princes in the world have found all sorts of difficulties follow marriage to a subject. There is besides the risk of the envy and jealousy of great and powerful nobles, in the contempt they always feel for men of inferior station, if she insists on marrying the man of her preference ... On the other hand no foreign prince who tries to rule over an alien people can be secure of his life unless he lives behind fortifications, and goes about strictly guarded. But if he thus has 
control of the armed forces he can control the state, and in order then to make himself the more secure, he is tempted to advance his own compatriots. This is a thing which no nation in the world will endure. We have a thousand examples, among them that of William of Sicily. In 1268 the people of Naples were so enraged that a Frenchman should be promoted to the office of chancellor that they conspired to kill, and in fact did kill every Frenchmen in either Naples or Sicily. If the foreigners are not the stronger party, they get their throats cut on the slightest provocation by patriots. ...

If natural law is violated by gynecocracy, so are the civil law and the law of nations, and to an even greater degree. By them the woman is required to follow her husband though he have neither lands nor possessions. In this opinion canonists, doctors of civil law, and theologians are all agreed. The woman is bound in obedience to her husband, her dowry is his by right, as are likewise all properties accruing to her ... Nevertheless under the marriage treaty between Philip of Castile and Mary, Queen of England, contrary principles were laid down, although many are of opinion that when a foreigner marries a queen, the rights and revenues of the kingdom belong to him, although the kingdom, and sovereign authority over it inheres in the queen ... Such are the inconveniences and absurdities attendant on gynecocracy.

The most excellent conclusion possible to this whole work is a discussion of justice, since such is the foundation of all commonwealths. It is of such importance that Plato called his book on the Republic a discussion of right or justice. It is to be observed that he spoke as a philosopher rather than as a legislator or a jurist.

Concerning Distributive, Commutative, and Harmonic justice, and their Relation to the Aristocratic, Popular and Monarchical States [CHAPTER $\mathrm{VI}]$

THE nearer a kingdom approaches to realizing harmonic justice, the nearer it is to perfection. By justice I mean the proper distribution of rewards and punishments, and of those advantages due to each individual as a matter of right. This distribution must be based partly on the 
principle of equality and partly on that of similarity, which properly conjoined issue in harmonic justice[4] ... But neither the Greeks, the Romans, nor anyone since has considered it either in relation to the administration of the law, or the government of the commonwealth. Yet it is the most perfect form of justice, and proper to a royal monarchy, governed in part through popular, in part through aristocratic institutions. ...

Geometric or distributive proportion is based on the principle of similarity, arithmetic or commutative proportion on the principle of equality. Harmonic is a fusion of the two which nevertheless does not resemble either ... Government by distributive proportion unites like to like. This is illustrated by the marriage laws of the Twelve Tables, under which nobles were required to marry nobles, commoners, commoners. This rule is still strictly followed in Ragusa. By this principle princes should only marry princesses, wealthy men rich wives, poor men poor ones, and slaves slaves. If however marriages were arranged by casting lots, a slave might marry a king. Poor and humble people would not ask anything better, for they want to make things more equal. But these two principles of government both involve many disadvantages, for by the one the poor are oppressed, and by the other the nobles slighted. The harmonic principle however unites the two. Still keeping to the example of the marriage laws, one would not insist that noblemen of four quarterings should only marry those of a like descent, as is still the case in some places in Germany... It is better if the rich burgess marries a poor noblewoman, or a poor gentleman a rich commoner, the man with some grace of mind a wife with some grace of body. This is to be preferred to marriages between people quite alike in all respects. We see the same thing in business, for the most successful partnerships are those between a rich sleeping partner and a poor man of ability to run the business. There is both equality and similarity between them. Equality in that each has some contribution to make, similarity in that each lacks some indispensable attribute. ...

An egalitarian order, based on the principle of commutative justice, is natural to popular states. It is agreed that estates, honours, offices, benefices, booty, and confiscated lands ought to be equally divided, and that when laws are to be made, officers appointed, or a matter of life 
and death determined, everyone is called upon to take part, the most foolish and irresponsible having exactly the same importance and influence as the wisest... In popular states everything is decided by lot, and regulated by fixed and invariable laws, not susceptible of any equitable interpretation, nor admitting any privilege or exception of persons, so that nobles are liable to the same punishments as commoners, fines imposed on the rich are the same as those imposed on the poor, and the same rewards are bestowed upon the able and the feeble, upon the commander of an army and the private soldier.

On the other hand aristocracies are regulated by the principle of distributive justice ... and it is agreed that the execution of the law ought to be adapted to the circumstances of each case. It is however impossible that a so-called law can really be regarded as such if it is indefinitely flexible. A law is not properly speaking a law if it is as malleable as wax, and the man who should obey it can mould it as he wills. In order therefore to avoid on the one hand the unmitigated rigidity of the commutative principle, and the variability and uncertainty of the distributive on the other, one needs to find a third principle which is not so rigid that it cannot be modified if circumstances require it. One must, in fact, aim at the principle of harmonic justice, which combines harmoniously law, equity, the execution of the law, and the function of the magistrate, both in the administration of justice, and in the governance of the state. In the series $4,6,8,12$, there is the same ratio between 4 and 6 as there is between 8 and 12, and also between 4 and 8 as there is between 6 and 12 . Similarly there is the same relation between law and equity as there is between the execution of the law and the function of the magistrate, and also between law and its execution as there is between equity and the function of the magistrate....

If we apply this to the commonwealth, whether sovereign power is vested in a prince, the nobles, or the entire people, and the state be a monarchy, an aristocracy or a popular state, if it is governed without law and all is left to the discretion of the magistrates to distribute pains and penalties according to the importance and status of each individual, such a state could be neither stable nor durable, even though it had a fair appearance because all was managed without fraud or 
favour, a thing impossible in itself. There would be no bond of union between the great and the humble, and therefore no harmony between them. There is even less stability where a principle of strict equality is observed, and all matters are regulated by immutable laws, without any means of equitable adjustment to suit the requirements of time, place, and persons. Just as two simple substances, qualitatively extreme opposites, may be each in themselves lethal, yet combined and tempered the one by the other produce a health-giving medicine, so the two opposed principles of commutative and distributive justice are in themselves destructive of commonwealths, but combined as harmonic justice supply the means of their preservation.

Aristotle was therefore wrong in maintaining that that state was happy which was governed by so good a ruler that he was never swayed by prejudice or passion, for in such a case, he said, there would be no need of laws. But laws are not for those who exercise sovereign power, as we have already shown. They are intended in the first place as a guide to magistrates, who are frequently so bunded by passion, by intrigues, or by ignorance, that they have no conception at all of the beauty of justice. Even were they very angels, incapable of any fault, the subject still has need of the law to illumine a path for him amid the dark promptings of his heart. Wicked men need it to prevent them excusing their misdeeds on the grounds of real or pretended ignorance. Again, if for no other reason, the law is required to fix punishments, for knowledge of what is the appropriate punishment is not rooted in conscience as is knowledge of what are those actions forbidden by natural law....

The first occasion of men making laws was when primitive monarchies were converted to popular states, as happened in Athens in the time of Dracon and Solon, and in Sparta when Lycurgus broke the power of the two kings. The common people demanded equality with the rich and the noble, and this could only be achieved through equalizing laws. The rich on the other hand insisted on their privileges. Because the burden of maintaining the commonwealth fell on them, they considered that the rich should be advanced in proportion to the size of their estates and the importance of their charges. Therefore the Tribune Terentius Arsa proposed a law to the people requiring the magistrates for the future to 
be guided in their actions by certain fixed rules. The nobles opposed the measure, which to them spelt ruin, and would have preferred to restore the monarchy. The matter was disputed for six years, but in the end the commons defeated the nobles. The Twelve Tables were therefore published, including a provision that no privilege was to be granted anyone, on pain of death, at least without the consent of the popular assembly. Under these laws the magistrates were required to govern by strict rules which did not permit of any exercise of discretion, or appeal to equity....

It is important to notice however that the word equity can be used diversely. Equity in a ruler is the power to declare or to correct the law. In a magistrate it is the power of applying it by relaxing its rigour or stiffening its leniency when there is need, and by supplying its defects where its provisions are inadequate to a given case ... In this respect the most humble judges have the same kind of discretion as the most exalted, but neither of them can do what a sovereign court can, that is to say reverse a judgement on appeal, or exempt an accused person entirely from paying the penalty under the law. They can only act within their terms of reference ... But to speak truly, law without equity is like a body without a soul, seeing that the law can only lay down general rules, while equity is dependent on the circumstances of particular cases, which are infinitely variable. The law must be accommodated to these circumstances, whether it is a matter of the administration of justice or affairs of state, if awkward or absurd consequences are to be avoided. The magistrates however must not bend the law so much as to break it, even if it is a severe law, when its intention is unambiguous ... As an ancient doctor once said, it does not pertain to the magistrates to judge of the law, but to judge according to the law. If he does otherwise, he is by common agreement unworthy of his office ... The magistrate is under the law, and equity should be in his soul, whereby it is his duty to supply its defects, and elucidate its principles, for the right interpretation of law is the very essence of law. ...

In nearly all the customs and ordinances of this realm, fines are of fixed amounts ... and embody a clause 'it is forbidden to our judges to modify this penalty'. If the convicted person has not the wherew ithal to 
discharge the fine imposed for his default or fraud, by a general rule common to all peoples, he must then suffer corporal punishment. To this it may be objected that it is unjust to condemn a poor man to a fine of say sixty livres on some frivolous charge, and require no greater sum from a rich man. By the principle of distributive justice, if a poor man whose total assets only amounted to one hundred livres was sentenced to a fine of sixty livres, the rich man who has one hundred thousand livres ought to pay sixty thousand livres, since sixty bears the same proportion to a hundred, as sixty thousand to a hundred thousand. The consequence is that in the one case the principle of distributive justice deprives the rich of their privileges, and in the other the principle of commutative justice can be used by the rich as a means of ruining the poor under the cloak of justice. For this reason our ordinances permit a judge to levy an extraordinary fine where the circumstances warrant it, in addition to the ordinary amount fixed by law. This comes very near the principle of harmonic justice. What further is required is that the ordinances should allow judges, or at least supreme courts also to abate a fine, having regard to the resources of the poor and ignorant, as in fact is always done by the high court of Rouen ... But he who would be guided by the principle of strict distributive justice, and make the punishment exactly fit both the crime and the criminal must give up the attempt to formulate laws for this purpose, for the variety of persons, acts, times, and places is infinite, and cannot be comprehended within the scope of any general rule. On the other hand a strict equality of penalties on the principle of commutative justice is unjust. ...

However although a popular state is characterized by equal laws on the principle of commutative justice, whereas an aristocracy preserves the principle of distributive justice, each must borrow something from the other if they are to be preserved, and so approximate to harmonic justice. Otherwise, were an aristocracy to exclude the common people from the estates, and from all honours and offices, denying them any share in the spoils of war or conquered territories, the common people, however much they might be strangers to arms, would revolt and bring a revolution in the government as soon as an opportunity offered. This may be seen in the Signory of Venice, which is an aristocracy if ever there was one, and governs itself in accordance with aristocratic principles, 
reserving all high honours and dignities, benefices, and magistracies to Venetian gentlemen, and only giving subordinate offices to which no power is attached to commoners, following therein the principle of distributive justice, much to the great, little to the humble.

Nevertheless, in order to keep the common people content, they open to them the office of Chancellor which is one of the highest and most honourable, besides being a perpetual office. To this they add the Secretaryships of State, also very important and honourable offices. Furthermore the least offence committed by a Venetian gentleman against any inhabitant of the city is strictly punished, and indeed, there is a general ease and liberty for all which is more suggestive of a popular than an aristocratic state. Magistrates are appointed by a mixed system of election and lot, the one characteristic of aristocracies, the other of popular states. In short, the two types of institutions are so well combined that it is clear that though an aristocracy, it is the fact that it is regulated according to the principles of harmonic justice that has made this republic so admirable and so nourishing. ...

The monarchical state is necessarily founded upon the principles of harmonic justice, and if it is governed royally, that is to say harmoniously, it is the best, the most happy, and the most perfect type of state there is. I do not include despotic monarchy where the king, as the natural lord of his subjects, governs them as his slaves, disposing of their persons and their goods as he thinks fit. Still less do I include tyrannies where the king, not being the natural lord of his subjects, usurps an improper authority over their persons and their possessions, reducing them to slavery, and worst of all, making them the objects of his cruelty. I am speaking of legitimate monarchy, whether elective, hereditary, or founded in a conquest voluntarily submitted to, where the king's relations to his subjects is that of a father to his children, for he does justice among them.

A king can however, in the first place, govern his kingdom as if it were a popular state, on egalitarian principles, throwing open all public office whatsoever to all his subjects indifferently, without distinguishing merit, or suitability, by the means of filling offices, either by casting lots, or by a strict system of rotation. There are however few or none such monarchies. Or the king can govern his kingdom 
aristocratically, distributing honours and honourable charges, rewards and penalties in proportion to the nobility of some, and the wealth of others, but excluding poor commoners, without regard to their merits, but singling out only those with birth or wealth.

Though both these systems are bad, the latter is much the more tolerable since it approaches nearest to an harmonious system. For the king, in order to protect his authority from the envy of the common people, inclines to the nobility, whose quality more nearly approaches his own than that of the commoners, with whom he is not on terms of social intercourse, for he cannot very well so far abate his dignity as to be on terms of familiarity with them. He would have to do this if he were to open honours and honourable charges to them. Such a government however is as damaging to the noblesse and the king as it is to the commons, for they both necessarily live in fear of the discontented masses, who must always heavily outnumber the rich and the nobly born. If they take to arms they are the stronger party, and can rise against the king, expel the nobility, and defy his authority, as happened with the Swiss, and many commonwealths in the ancient world. The explanation is obvious. The common people were not bound by any tie either to the king or to the nobility....

A wise king ought therefore to govern his kingdom harmoniously, subtly combining nobles and commons, rich and poor with such skill as always to preserve some advantage for the noble over the commoner. For it is right that the gentleman who is as practised in arms and in law as a commoner should be preferred to him in matters of justice and of war, or that the rich man, equal in all other respects to the poor one should be preferred in those offices which carry with them greater honour than profit. Both will then be content, for the rich man only looks for honour, but the poor man for profit... There is no way of combining great and small, nobleman and commoner, rich and poor, save by giving estates, dignities, and benefices to those who deserve them. But deserts are various. If responsible and honourable charges were only given to the virtuous the commonwealth would always be in a state of confusion, seeing that such men are always few in number, and easily overcome by the rest. But in associating upright men now with nobles, now with rich citizens, even though these last may be quite devoid of virtue, they are 
nattered to be associated with those who possess it, while they in their turn are gratified to find themselves advanced to some honourable employment. Thus on the one hand the nobility are satisfied that birth is respected in the distribution of honours, on the other the commons are deeply gratified and feel themselves generally honoured. In fact they are so honoured when the son of a poor physician can become the Chancellor of a great kingdom, or the son of a poor soldier High Constable, as happened in the case of Michel de l'Hôpital and Bertrand du Guesclin among many others, whose virtues alone led to their promotion to the very highest offices. But all classes see with impatience the most unworthy promoted to the most responsible positions, though it is occasionally necessary to give some offices to incapable and unworthy persons, provided it is done so sparingly that their ignorance or vice cannot do any great harm in the position they hold. It is not sufficient to entrust finance to the most trustworthy, war to the most valiant, justice to the most upright, censure to the most incorruptible, work to the strongest, government to the wisest, religion to the most devout, as the principle of distributive justice requires, though this in fact cannot be achieved because of the scarcity of good men. To ensure a general harmony one must combine those who can supply one another's shortcomings. Otherwise there will be no harmony than if one sounded separately notes sweet in themselves, but only capable of producing a consonance when struck together. In doing this the prince reconciles his subjects to one another, and all alike to himself. ...

The prince exalted above all his subjects, whose majesty does not admit of any division, represents the principle of unity, from which all the rest derive their force and cohesion. Below him are the three estates, which have always been disposed in the same way in all well-ordered commonwealths. The estate of the clergy is placed first because of its dignity in ministering to religion. It includes both nobles and commoners. Next comes the military estate, which also includes nobles and commoners. Last there is the third estate of scholars, merchants, craftsmen, and peasants. Each of these three estates should have a share in public offices, benefices, jurisdictions, and honourable charges, each according to the merits and qualities of persons. Thus an admirable harmony will subsist between the subjects themselves, and the subjects and their prince ... Aristocratic and popular states also nourish and 
maintain a government. But they are not so well united and knit together as if they had a prince. He unites all parts and relates them one to another ... One can regard the three estates as characterized by prudence, courage, and temperance respectively. These three virtues complement each other, and that of the king, who supplies the rational and contemplative element. Such a form of commonwealth is harmonious and therefore admirable, for the union of its members depends on unity under a single ruler, on whom the effectiveness of all the rest depends. A sovereign prince is therefore indispensable, for it is his power which informs all the members of the commonwealth....

1. The heading of the chapter is simply LA CENSURE. Bodin uses the term for both census and censorship, following the union of these two functions in a single magistrate in Rome.

2. Chapter III deals with the establishment of a pure standard coinage, and is an abstract of his tract on currency already referred to (see note, p. 47).

3. In August 1573 a magnificent Polish embassy arrived in Paris to conduct the Duke of Anjou back to Poland, following his election to the throne in the preceding May. Bodin was a member of the deputation that met the embassy at Metz.

4. As a Platonist Bodin thought that moral as well as physical relationships could be expressed mathematically. So, commutative justice, or the principle of equality, is like an arithmetical progression -- 3, 9, 15, 21 -- arising from the addition of a constant number. Distributive justice, or the principle of similarity, is like a geometrical progression -- 3, 9, 27, 81 -- made by multiplication in a constant ratio. The only way of combining these diverse kinds of proportion is in a harmonic progression -- 3, 4, 6, 8, 12 -- in which alternate terms are in a constant ratio, but consecutive terms linked by a number alternately added and multiplied. This he thought provided a scheme of subtle and complex relationships more expressive of right order in the commonwealth than either of the other two, which only allow 
of one uniform relationship. For clarity, the mathematical formulae have been translated into their political equivalents throughout the chapter. 